\title{
Distribution TABLES AND FedERAL TAX POLICY: A SCORING INDEX AS A METHOD FOR EVALUATION
}

\author{
Jason J. Fichtner
}

A dissertation submitted to the faculty of Virginia Polytechnic Institute and State University in partial fulfillment of the requirements for the degree of

\section{Doctor of Philosophy}

In

\section{Public Administration and Policy}

Center for Public Administration and Policy

Philip S. Kronenberg, Ph.D., Committee Chair Larkin Dudley, Ph.D., Committee Member Anne Meredith Khademian, Ph.D., Committee Member James F. Wolf, Ph.D., Committee Member

October 31, 2005

Alexandria \& Blacksburg, Virginia

Keywords: federal taxation, tax policy, tax distribution analysis, tax reform, income distribution, problem definition, issue framing, agenda setting, strategic management 


\title{
Distribution TABles AND Federal TAX Policy: A SCORING INDEX AS A METHOD FOR EVALUATION
}

Jason J. Fichtner

\begin{abstract}
Distribution tables have become ubiquitous to the tax policy debates surrounding major legislative initiatives to change tax law at the federal level. The fairness of any proposed change to federal tax policy has become one of the most highlighted components of tax policy discussions. Most research on tax distribution analysis focuses on methodological issues for properly measuring a change in tax burden. However, published research on how different methodologies and presentations of data are used in tax distribution analysis to influence and define the boundaries of the issue has not kept pace. Given the prominent role distribution tables have come to play in the tax policy process, it is appropriate and necessary to have a more thorough understanding of how different methodologies and presentations of results affect the portrayal of proposed changes to federal tax policy.
\end{abstract}

The presentation of tax data within distribution tables can hide or omit important information that is required in order to effectively evaluate the merits of any tax legislation. Many producers of distribution tables show only the information necessary to present their policy preferences in the best possible light. The different economic assumptions and presentations of data used by the various groups that release distribution tables have the inherent consequence of providing the public with numerous tables that are often used as political ammunition to influence and shape debate.

The purpose of this research is to contribute to the tax policy research literature by exploring the limitations and biases inherent in specific designs of tax distribution tables and in specific methodological approaches to tax distribution analysis. This is done by means of a systematic examination of how, in current practice, different designs and methodologies provide an incomplete picture of a proposed change to federal tax policy. By comparing distribution tables as used by different groups to provide alternative perspectives of various tax proposals, the research shows how the use of tax distribution tables often provides misleading results about the impact of proposed tax legislation in order to influence and shape the issues surrounding a proposed change to federal tax policy.

Finally, a method for evaluating tax distribution tables is proposed which will highlight the deficiencies of design and methodology which characterize the present use of tax distribution tables. An index of questions is provided as part of this research project to serve as a new tool of policy analysis, an index I have created and termed the "Tax Distribution Table Scoring Index" (TDTSI). The TDTSI will assist in balancing the different perspectives presented via tax distribution tables by identifying the biases and limitations associated with different methodologies and presentations of data. The utility of the TDTSI is as an evaluation tool to reveal the perspectives presented and balance any misleading or biased presentations of data in tax distribution tables. The results of the comparative research on the design and methodology of tax distribution tables together with the demonstration of the TDTSI as an analytical tool both contribute to the critical debates in the tax policy research literature as well as provide reform and add value to the practical use of tax distribution tables by policy makers and the public. 


\section{ACKNOWLEDGEMENTS}

The road to completing a Ph.D. is long and difficult. It is a marathon, not a sprint. This doctoral dissertation is the end result of several years of hard work, research, inquiry and discovery. I would not have been able to reach this milestone without the support of many people. While all of my friends, family and colleagues supported me immensely in this endeavor, several people deserve individual thanks.

First of all, I'd like to thank my wife Shelley. For a person who really could not care less about tax policy she was always there supporting my efforts, successes, failures and the general ups and downs that occurred throughout my quest for a Ph.D. Second, thanks to my entire cast of family and friends for being supportive and encouraging me along the way. Though I probably never said it, your interest and support of my educational aspirations have meant a lot to me.

A very special thanks to my dissertation committee chair, Dr. Phil Kronenberg. A successful dissertation is not possible without an excellent chair and mentor. I will always be indebted for his expert guidance, unwavering support and friendship. I would also like to thank the rest of my committee members: Dr. Jim Wolf who has always been eager and interested to discuss my research and provide helpful assistance; Dr. Larkin Dudley who as much as anybody helped me survive my Blacksburg experience and make it memorable; and Dr. Anne Khademian for her support and willingness to lend her expertise. I am honored and humbled to have such a distinguished and supportive group of scholars on my dissertation committee. Additionally, I'd like to thank Dr. John Rohr, who always provided friendly conversation and support.

For providing me employment and for supporting my research endeavors over the past six years, I wish to thank Congressman Jim Saxton, Chairman of the Joint Economic Committee (JEC) of the United States Congress, and Chris Frenze, Executive Director of the JEC. This dissertation would not have been possible without their support and guidance. Additionally, several staff members of the JEC have consistently provided me with support and friendship. To all on the JEC I give you my thanks.

Several friends went above and beyond the call of duty in support of my pursuit for a Ph.D. I can never thank Dan Miller enough for being a springboard for my ideas and his willingness to read draft, after draft, after draft, and to always provide helpful comments. Thanks to Dr. Jen Victor who provided very useful guidance and feedback on the dissertation research as it evolved and developed. To my comrades in arms at Virginia Tech: Dr. Anne Pritchett, Pat Mullen, Ron Millar, Ed Gibson, and Susana Limon - from prelims to defense you have all been an anchor of support to me. Thank you. 


\section{TABLE OF CONTENTS}

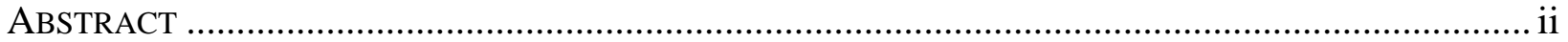

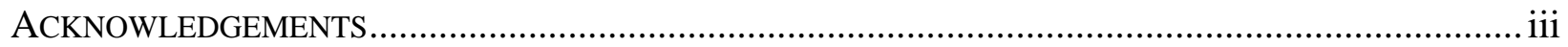

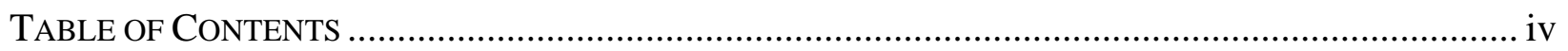

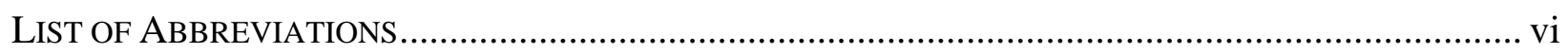

LisT OF TAX DistRIBUTION TABLES USED IN DiSSERTATION RESEARCH....................................... vii

LIST OF CHARTS AND OTHER TABLES …………………...................................................... ix

Chapter 1 - Problems with TAX Distribution TABles - Issues \& SetTing ................................ 1

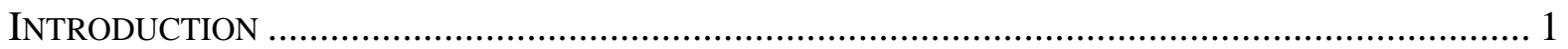

PURPOSE OF THE DISSERTATION RESEARCH …………….................................................... 3

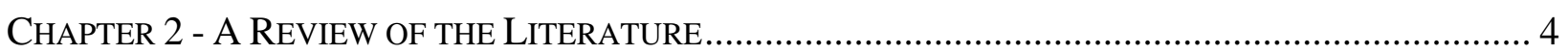

ECONOMICS - TAX POLICY LITERATURE ………………….......................................... 4

PUBLIC FINANCE .......................................................................................................... 7

Political Science, Public Policy and Politics - Agenda Setting And Issue

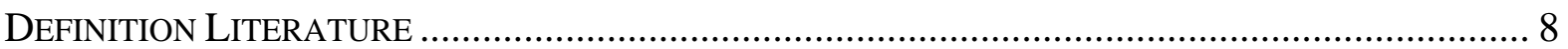

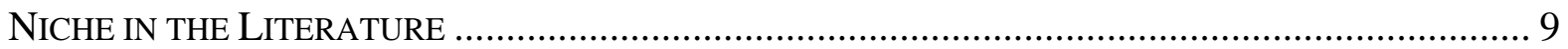

CHAPTER 3 - RESEARCH DESIGN .............................................................................................. 10

A Tax Distribution TAble SCoring IndeX as a ToOl of Policy Analysis ...................... 11

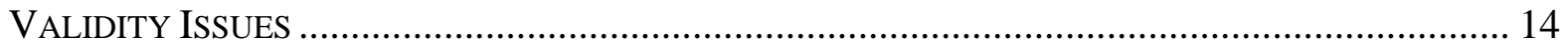

Chapter 4 - Fundamental Problems Associated with Tax Distribution Tables .............. 19

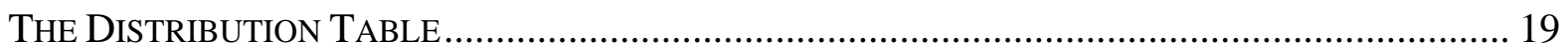

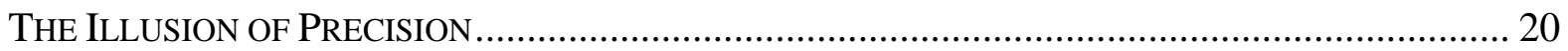

WHAT IS INCOME AND WHO ARE THE RICH? ..................................................................... 22

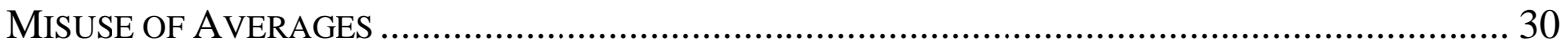

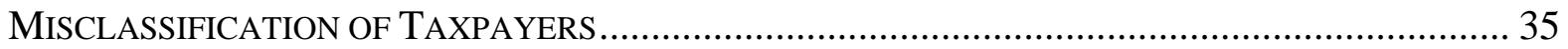

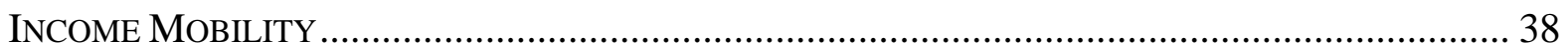

STATISTICAL STANDARDS, SAMPLING AND ACCURACY …………………………………......... 42

Statistical ACCURACY AND Reliability Combining Data SETS OF DifFERENT SAMPLE

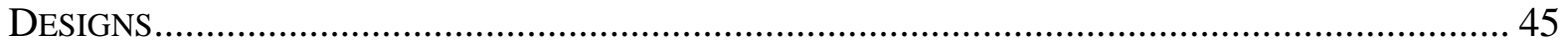

Chapter 5 -How Tax Distribution Tables are Used/Misused in Tax Policy \& Why a TOOL FOR EVALUATING TAX DistRIBUTION TABLES IS NEEDED ...................................................... 47

Chapter 6 - TAX Distribution Table SCORing Index (TDTSI) - A NeW TOOL OF Policy

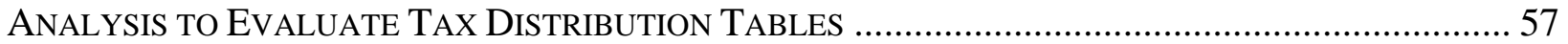

A Tax Distribution Table SCoring IndeX as a ToOl of Policy ANalysis ..................... 57

CHAPTER 7 - AN APPLICATION OF THE TAX Distribution TABLE SCORING INDEX (TDTSI) TO

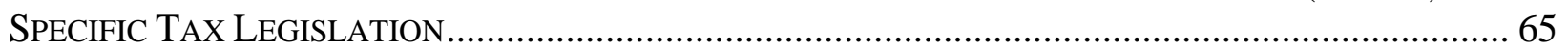

OMNIBUS BUdGET RECONCILIATION ACT OF 1993 (OBRA 93) …………………………...... 65

SUMMARY OF TDTSI RESULTS - OMNIBUS BUDGET RECONCILIATION ACT OF 1993............. 75

TAXPAYER RELIEF ACT OF 1997 (TRA 97) …………........................................................... 75

SUMMARY OF TDTSI RESULTS - TAXPAYER RELIEF ACT OF 1997 ...................................... 82 
ECONOMIC GROWTH AND TAX RELIEF RECONCILIATION ACT OF 2001(EGTRRA 01) ......... 83

SUMMARY OF TDTSI RESULTS - ECONOMIC GROWTH AND TAX RELIEF RECONCILIATION

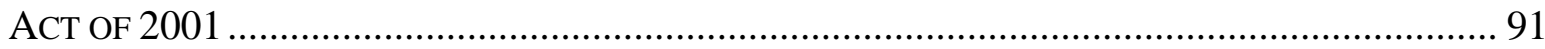

JOBS AND GROWTH TAX RELIEF AND RECONCILIATION ACT OF 2003 (JGTRRA 03)........... 92

SUMMARY OF TDTSI RESULTS - JOBS AND GROWTH TAX RELIEF AND RECONCILIATION

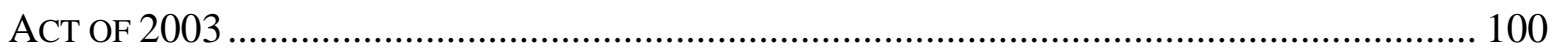

WORKING FAMILIES TAX RELIEF ACT OF 2004 (WFTRA 04) ........................................ 102

SUMMARY OF TDTSI RESULTS - WORKING FAMILIES TAX RELIEF ACT OF 2004............... 106

MiSCELLANEOUS TAX DISTRIBUTION TABLES ............................................................ 107

SUMMARY OF TDTSI RESULTS - MISCELLANEOUS TAX DISTRIBUTION TABLES ................ 111

TAX DISTRIBUTION TABLES WHERE THE TDTSI FAILS................................................ 112

SUMMARY OF TDTSI RESULTS - TAX DISTRIBUTION TABLES WHERE THE TDTSI FAILS .. 115

Summary of Results - The Tax Distribution TABle SCoring IndeX as a ToOl of

Policy Analysis to Evaluate Policy Perspectives in Tax Distribution Tables ... 116

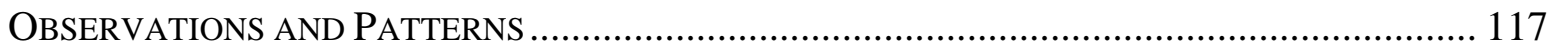

EVALUATION OF THE INDIVIDUAL QUESTIONS THAT COMPRISE THE TDTSI ..................... 119

ADDITIONAL QUESTIONS THAT COULD BE ADDED TO THE TDTSI ….............................. 121

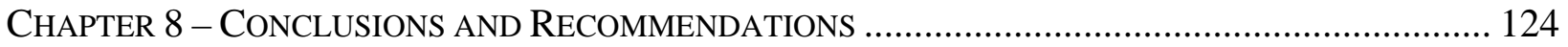

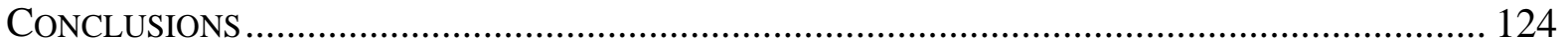

RECOMMENDATIONS FOR FOLLOW-ON RESEARCH ................................................... 126

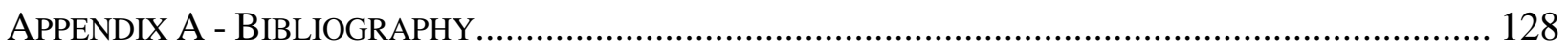

APPENDIX B - SELECTED RESOURCES FOR FUtURE READING …............................................. 134 


\section{List of AbBREViations}

\begin{tabular}{|c|c|}
\hline AGI & Adjusted Gross Income \\
\hline CBO . & Congressional Budget Office \\
\hline CBPP & Center on Budget and Policy Priorities \\
\hline CTC & Child Tax Credit \\
\hline CTJ & Citizens for Tax Justice \\
\hline EGTRRA . & $\begin{array}{l}\text { Economic Growth and Tax Relief Reconciliation } \\
\text { Act }\end{array}$ \\
\hline EIC or EITC & Earned Income Tax Credit \\
\hline FEI .... & Family Economic Income \\
\hline GOP & $\begin{array}{l}\text { Grand Old Party (reference to the Republican } \\
\text { party) }\end{array}$ \\
\hline IRA & Individual Retirement Accounts (Arrangements) \\
\hline JCT & Joint Committee on Taxation \\
\hline JEC & Joint Economic Committee \\
\hline JGTRRA . & $\begin{array}{l}\text { Jobs and Growth Tax Relief and Reconciliation } \\
\text { Act }\end{array}$ \\
\hline OBRA & Omnibus Budget Reconciliation Act \\
\hline OTA .. & Office of Tax Analysis \\
\hline TDTSI . & Tax Distribution Table Scoring Index \\
\hline ТPC ... & Tax Policy Center \\
\hline TRA & Taxpayer Relief Act \\
\hline WFTRA & Working Families Tax Relief Act \\
\hline
\end{tabular}




\section{List of TAX DisTRIBUTION TABLES USED IN DisSERTATION RESEARCH}

1) Table 5-1 -““'Major Provisions Passed by the House Ways and Means Committee," Office of Tax Analysis, Department of the Treasury July 17, 2000

2) Table 5-2 - "Major Individual Income Tax Provisions of the President’s Tax Proposal,” Administration Office of Tax Analysis, Department of the Treasury, March 8, 2001

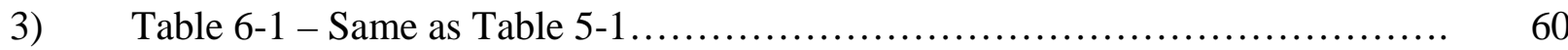

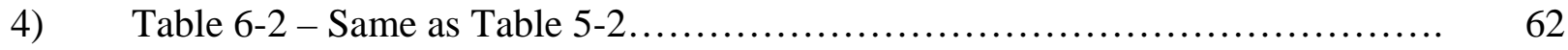

5) Table 7-1 - "Distributional Effects of the Revenue Provisions Contained in the 1993 OBRA as Agreed to by the Conferees,” Joint Committee on Taxation, August 3, 1993. As reprinted in Barthold, Nunns, and Toder in Bradford (Editor) (1995), page 102

6) Table 7-2 - "Distribution of the Estimated Change in Tax Liabilities Due to Provisions in OBRA, Including Taxation of Social Security Benefits and Expansion of EITC and Food Stamps,” Office of Tax Analysis, undated. As reprinted in Barthold, Nunns, and Toder in Bradford (Editor) (1995), page 101

7) Table 7-3 - "Tax Burdens Before and After the 1993 OBRA, by Adjusted Family Income and by Family Dollar Income,” Congressional Budget Office, undated. As reprinted in Barthold, Nunns, and Toder in Bradford (Editor) (1995), pages 97-98.

8) Table 7-4 - "Comparing the Original, House, Senate \& Final Version of the 1993 Clinton Tax Plan,” Citizens for Tax Justice, August 5, 1993.

9) Table 7-5 - "Distributional Effects of the Conference Agreement on the Revenue Provision of H.R. 2014," Joint Committee on Taxation, July 31, 1997. JCX-4197 (September 4, 1997).

10) Table 7-6 - "Major Tax Cut Provisions in the Ways and Means Chairman's Mark (Very Preliminary)," Office of Tax Analysis, June 11, 1997.

11) Table 7-7 - “Three Contrasting Tax Plans,” Citizens for Tax Justice, June 23, 1997.

12) Table 7-8 - "Distributional Effects of the Conference Agreement for H.R. 1836," Joint Committee on Taxation, JCX-52-01, May 26, 2001........................ 85

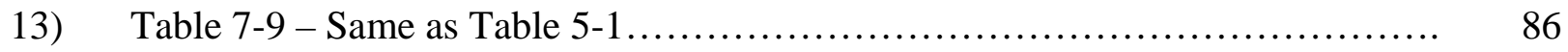

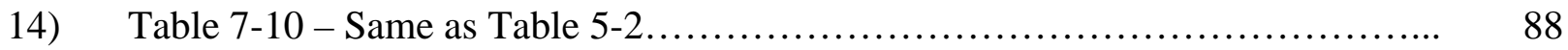


15) Table 7-11 - "Effects of the Senate Finance Committee-passed version of the Bush tax plan,” Citizens for Tax Justice, May 16, 2001.

16) Table 7-12 - “Jobs and Growth Tax Relief Reconciliation Act of 2003,” Office of Tax Analysis, May 22, 2003................................................

17) Table 7-13 - “Table T09-0107 - Conference Agreement on the Jobs and Growth Tax Relief Reconciliation Act of 2003,” Tax Policy Center, May 22, 2003

18) Table 7-14 - “Table T09-0108 - Conference Agreement on the Jobs and Growth Tax Relief Reconciliation Act of 2003,” Tax Policy Center, May 22, 2003

19) Table 7-15 - "Effects of the House GOP 2003 Tax Cut Plan in 2003-06," Citizens for Tax Justice, May 6, 2003.

20) Table 7-16 - “Table T04-0153 - Conference Agreement on H.R. 1308, The Working Families Tax Relief Act of 2004,” Tax Policy Center, September 23, 2004

21) Table 7-17 - “Table T04-0154 - Conference Agreement on H.R. 1308, The Working Families Tax Relief Act of 2004,” Tax Policy Center, September 23, 2004.

22) Table 7-18 - "Updated Distribution of Certain Federal Tax Liabilities by Income Class for Calendar Year 2001,” Joint Committee on Taxation, JCX-65-01, August 2, 2001

23) Table 7-19 - "Who Benefits?: Distribution of Bush Administration Tax Cuts in 2004," Center on Budget and Policy Priorities, in "Studies Shed New Light on Effects of Administration's Tax Cuts, pg. 5, Revised September 13, 2004

24) Table 7-20 - “Table T04-0102 - Current-Law Distribution of Individual Income Tax By Amount of Income Tax Paid, 2004,” Tax Policy Center, May 24, 2004.

25) Table 7-21 - "Bush Tax Plan Benefits are Similar to Campaign Proposal: Skewed Toward Wealthy,” Citizens for Tax Justice, February 8, 2001.............

26) Table 7-22 - “Table T03-0142 - Conference Agreement on Jobs and Growth Tax Relief Reconciliation Act of 2003,” Tax Policy Center, May 30, 2003

27) Table 7-23 - Summary of Tax Distribution Table Scoring Index Results 


\section{LIST OF CHARTS AND OTHER TABLES}

1) Table 4-1 - Illustration of a Tax Distribution Table........................... 19

2) Table 4-2 - How Averages Can Misrepresent Central Tendency................ 21

3) Table 4-3 - Treasury Overstatement of Income........................... 27

4) Chart 4-1 - Federal Income Tax Returns - Dispersion Around Average Federal Income Tax Liability.................................................. 31

5) Table 4-4 - Average Federal Income Tax Liability........................... 32

6) Table 4-5 - Returns With Negative or Zero Federal Income Tax Liability........ 33

7) Chart 4-2 - Federal Income Tax Returns: Dispersion Around the Average Third Quintile........................................................ 34

8) Chart 4-3 - Dispersion of Taxfilers by Federal Income Tax Liability............ 36

9) Chart 4-4 - Misclassified Taxpayers?................................................................. 37

10) Chart 4-5 - Misclassified Taxpayers?.............................................................. 37

11) Table 4-6 - Taxpayers by EGTRRA Rate Bracket Using Panel of Taxpayers

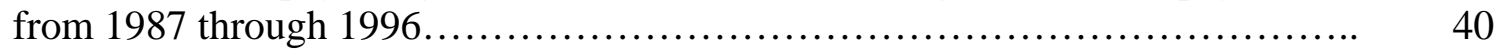

12) Chart 4-6 - Percentage of Federal Personal Income Tax Paid by Different Percentiles CY 2002...........................................................

13) Table 4-7 - Coefficients of Variations and Confidence Intervals for Selected

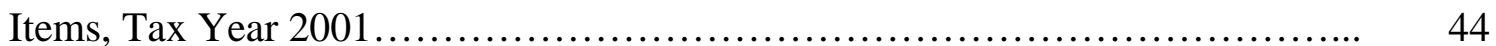

14) Chart 5-1 - Federal Individual Income Tax Burden in 2001.................. 51

15) Table 7-23 - Summary of Tax Distribution Table Scoring Index Results......... 116 
Jason J. Fichtner

\section{Chapter 1 - Problems With TAX Distribution TABles - IsSUeS \& SETTING}

\section{INTRODUCTION}

The topic of tax distribution analysis and tax distribution tables specifically is an extremely important issue for public policy. The taxation of individual income is a vital component of tax policy. Legislators evaluating the fundamental components of tax legislation face decisions that often redistribute tax burdens, after-tax income, and wealth among different members of society and, on a larger scale, can affect the performance of the greater economy. Large amounts of data are available to policymakers to help them make informed decisions relating to the costs and benefits of proposed tax legislation as well as distributional income and wealth effects. However, the quantity and mixed quality of these data can lead to confusion about the effects of proposed tax legislation. This confusion is compounded when competing or contradictory information is presented.

Tax distribution tables have become the predominant tool for analyzing the distributive effects of tax burdens and benefits from proposed changes to tax law. However, the use of tax data for tax policy analysis is a time intensive and complicated process that can be more art than science. The analysis of tax distribution is based on seven primary categories of information: the taxes included in the analysis, unit of analysis, time period of analysis, the way income is measured, incidence assumptions (who bears the burden of taxation), presentation of results, and data source(s) used. ${ }^{1}$ The inclusion or omission of any of these seven categories, along with the assumptions used for each category, affects the outcome of any tax distribution analysis.

Distribution tables have become ubiquitous to the tax policy debates surrounding major legislative initiatives to change tax law over the past two decades. The different economic assumptions and presentations of data used by the various groups that release distribution tables have the inherent consequence of providing the public with numerous tables showing different results that are then used as political ammunition to influence debate. Published research on the use of tax distribution tables has primarily focused on methodological issues for properly measuring tax burdens. ${ }^{2}$

However, the literature has not kept pace with how distribution tables are used in the policy process and how the inclusion (omission) of different variables and methodologies applied to the analysis of those variables can influence the way key information is perceived, portrayed or defined in the public arena. ${ }^{3}$ Given the prominent role distribution tables have come to play in the tax policy process, it is appropriate to examine not only the use of distribution tables in the

\footnotetext{
${ }^{1}$ John Barry, “Advances in Distributional Analysis,” (Ph.D. dissertation, George Mason University, 2004$), 3$.

2 See, for example, the thirty-two journal articles covering the last forty years in, Don Fullerton and Gilbert E. Metcalf, eds., The Distribution of Tax Burdens (Northampton, MA: Edward Elgar Publishing, Inc., 2003).

${ }^{3}$ However, the trade press and think tanks have published a few articles or commentaries that have added nicely to the debate. See, for example: Rudolph Penner, "Searching for a Just Tax System,” Discussion Paper No. 13, UrbanBrookings Tax Policy Center (January 14, 2004); Martin Sullivan, “Zen and the Art of Reading Distribution Tables,” Tax Notes, March 26, 2001; and Leonard Burman, “Treasury’s New Distribution Presentation Analyzed,” Tax Notes, March 26, 2001.
} 
tax policy process but also what distribution tables show and do not show. It is important to illuminate how various groups construct their distributional analyses in order to present data in a manner that best supports certain policy perspectives.

The limitations of the literature need critical examination because the current practice or use of distribution tables can provide a misleading sense of accuracy and an incomplete picture of the actual nature of a change in tax distribution as a result of a change to tax policy. ${ }^{4}$ FurchtgottRoth has argued that many tax distribution tables are "tailor-made" to produce a particular result. $^{5}$ Barry has claimed that "Scholars at many private research organizations also conduct distributional analyses of fiscal policy proposals...the results of which tend to vary depending on the political orientation of the organization sponsoring the work." 6 The full range of literature is discussed in Chapter 2.

Unfortunately, many tax distribution tables detailing the projected distribution of burdens associated with proposed tax legislation are presented in ways that can distort data or fail to disclose information regarding the limitations inherent in the data. Lacking such important information, informed debate over tax policy becomes difficult. Members of Congress, policymakers, students of tax analysis, the media and ordinary citizens seeking to understand the effects of proposed tax legislation are inundated with distribution tables that often obscure the issues and muddle the policy debate. A better and complete understanding of what distribution tables show, their limitations, and how different methodologies and definitions applied to key variables and the presentation of data within distribution tables can bias tax policy discussions is necessary. Further, a new policy tool is needed to evaluate the information presented (omitted) in tax distribution tables. This dissertation fills these needs.

The debates surrounding the five major tax bills signed into law between 1993 and 2004 are prime examples of the need to revisit the use of distribution tables. ${ }^{7}$ Numerous distribution tables were prepared by the Joint Committee on Taxation of the U.S. Congress (JCT), the Office of Tax Analysis of the U.S. Department of the Treasury (OTA), and various advocacy groups. Major newspapers around the country routinely publish these tables. ${ }^{8}$ However, without a proper understanding of what these distribution tables did and did not show, many important issues were misinterpreted or ignored altogether. These same issues are sure to rise again as tax policy proposals and tax reform ideas are debated in the future.

\footnotetext{
${ }^{4}$ See, for example, Martin Sullivan, “Zen and the Art of Reading Distribution Tables,” Tax Notes, March $26,2001$.

${ }^{5}$ See, for example, Diana Furchtgott-Roth., “Abuses of Income Distribution Tables in Tax Policy,” Tax Notes, December 11, 1995.

${ }^{6}$ John Barry, “Advances in Distributional Analysis,” (Ph.D. dissertation, George Mason University, 2004$), 2$.

${ }^{7}$ Four of the five major tax bills as identified by Jerry Tempalski, "Revenue Effects of Major Tax Bills,” U.S. Department of the Treasury, Office of Tax Analysis, OTA Paper 81 (Revised July 2003). The fifth bill is the Working Families Tax Relief Act of 2004.

${ }^{8}$ See for example: Jacob Schlesinger and John McKinnon, "Bush Plan Gives Rich Biggest Cut in Dollars But Not in Percentage,” The Wall Street Journal, November 5, 2000; Steven Pearlstein and Paul Blustein, “On the Class Warpath,” The Washington Post, February 7, 2001; Shailah Murray and David Rogers, "Democrats Attempt to Draw Rein As Republicans Study Wish Lists,” The Wall Street Journal, February 8, 2001; Glenn Kessler, “Treasury’s Tax Cut Data Can Cut 2 Ways,” The Washington Post, March 9, 2001; David Cay Johnson, "Even for Wealthy, Tax Plan’s Benefits Could Vary Widely,” The New York Times, May 15, 2001; and Glenn Kessler, “Tax Cut Debate’s Division Problem,” The Washington Post, May 17, 2001.
} 


\section{Purpose of The Dissertation Research}

The purpose of this dissertation research is to contribute to the tax policy research literature by exploring the limitations and biases inherent in specific designs of tax distribution tables and with specific methodological approaches to tax distribution analysis. "Design" of tax distribution tables refers to the inclusion or omission of variables from the analysis, while the "methodological" approach refers to how variables in tax distribution tables are measured. For example, a "design" issue might be whether to include a variable on after-tax income, while how income is measured would be considered a "methodological" issue.

A systematic examination of how, in current practice, different designs and methodologies provide an incomplete picture of a proposed change to federal tax policy is presented in this dissertation. By comparing distribution tables as used by different groups to provide alternative perspectives of various tax proposals and how they are perceived or portrayed in the public domain, the research shows how the use of tax distribution tables often provides misleading results about the impact of proposed tax legislation to influence and shape the issues surrounding a proposed change to federal tax policy.

Finally, a method for evaluating tax distribution tables is proposed which will highlight the deficiencies of design and methodology which characterize the present use of tax distribution tables. An index of questions is provided as part of this research project to serve as a new tool of policy analysis, an index I have created and termed the "Tax Distribution Table Scoring Index" (TDTSI). The TDTSI will assist in balancing the different perspectives presented via tax distribution tables by identifying the biases and limitations associated with different methodologies and presentations of data. The results of the comparative research on the design and methodology of tax distribution tables, together with the demonstration of the TDTSI as an analytical tool, both contribute to the critical debates in the tax policy research literature as well as provide reform and add value to the practical use of tax distribution tables by policy makers and the public.

The remainder of this dissertation is presented in six chapters. Chapter 2 reviews the related literature on tax distribution analysis drawing from the economics and public finance literatures. Additionally, since this dissertation research is also concerned with the manners in which alternative presentations of data can shape perspectives, the relevant political science, public policy and politics literatures are also discussed. Chapter 3 lays out the research design and methodology of this research dissertation. Chapter 4 provides a discussion and important overview of the fundamental problems associated with tax distribution tables. Chapter 5 demonstrates how the presentation of data in tax distribution analysis can distort perspectives and how tax distribution tables are used (misused) in tax policy. Chapter 6 introduces a new tool of policy analysis, the Tax Distribution Table Scoring Index (TDTSI), which will assist in balancing the different perspectives presented via tax distribution tables by identifying the biases and limitations associated with different methodologies and presentations of data. Chapter 7 applies the TDTSI to various tax distribution tables released surrounding the five major tax bills passed between 1993 and 2004 to demonstrate the TDTSI's utility as a new tool of policy analysis. Chapter 8 provides recommendations and a conclusion. 


\section{CHAPTER 2 - A REVIEW OF THE LITERATURE}

The literature of public policy is broad and concerned with the development of laws and regulations that impact society. Further, as a broad discipline, public policy draws from many literatures, such as economics, political science, public administration, government, public finance, etc. The topic of tax distribution analysis is not contained in one distinct literature, but rather covered in several broad literatures, primarily economics, public finance, and political science. The review of the literature for this dissertation triangulates on these three literatures, and this dissertation research contributes to all three.

Tax distribution analysis is covered primarily by economists (and sometimes tax lawyers) and appears in economic journals, or in law and public policy journals that cover the field of public finance and taxation. The literature does not adequately address the current importance and role of tax distribution tables in the tax policy process because the literature does not sufficiently deal with tax distribution tables as tools of strategic political management or demonstrate how the inclusion (omission) of different variables and the methodologies applied to the analysis of variables can provide different and misleading information to shape perspectives. Additionally, no tool of policy analysis yet exists in the literature that can be applied to evaluate tax distribution tables as a method for placing the information contained in tax distribution tables in proper context and further to make transparent the different perspectives that alternative designs and methodologies provide.

This dissertation research focuses on tax distribution tables and falls into the public policy literature directly under public finance but, as mentioned, also contributes to the related fields that make up the broader literature. The research being presented in this dissertation fills the gap in the economics literature relating to tax distribution analysis and further bridges the literatures by triangulating on the economics, public finance and political science literatures. These literatures are described briefly below.

\section{ECONOMics - TAX POLicy Literature}

The analysis of tax distribution, in general, is referenced throughout the economic literature. For example, Feenberg and Poterba (2000) note that "the recent evolution of the U.S. income distribution has attracted substantial attention in both academic and popular discussion." "With respect to tax distribution analysis, the economics literature has mainly focused on methodological issues.

In the early 1990's the National Tax Journal published several articles that explicitly discussed the use of distribution tables in the tax policy process and the proper methodological approaches to measuring tax burden and the effects of changes to tax law. ${ }^{10}$ Davis (1991), a former congressional staffer, recounts and comments on measuring distributional effects for the

\footnotetext{
${ }^{9}$ See, for example, Daniel R. Feenberg and James M. Poterba, “The Income and Tax Share of Very High-Income Households, 1960-1965,” American Economic Review 90, no. 2 (May 2000).

${ }^{10}$ See, for example: Albert J. Davis, "Measuring the Distributional Effects of Tax Changes for the Congress," National Tax Journal 46, no. 4 (September 1991); and Thomas A. Barthold, "How Should We Measure Distribution?” National Tax Journal 46, no. 3 (September 1993).
} 
Congress. Additionally, Barthold (1993), a staff member of the congressional Joint Committee on Taxation, wrote an article on how to classify taxpayers in distribution analysis to compare burden and over what time frame of analysis. Barthold also rejects as politically impractical a lifetime approach to tax distribution analysis, as suggested by Fullerton and Rogers (1993).

Several articles dealing with distributional analysis have also appeared in law journals. Michael J. Graetz, a former official with the U.S. Department of Treasury and highly respected tax expert, authored an article in the Columbia Law Review that discusses how the congressional tax policy process is more dependent on making the numbers in revenue and distribution tables look right than on economic and policy considerations. ${ }^{11}$ As Graetz states,

This increased reliance on distributional tables and revenue estimates as outcomedeterminative factors in tax legislation presents two quite different problems. Although it is important to know the likely effect of proposed tax legislation on total federal finances, with regard to revenue effects, policymakers are often asking the wrong question. Rather than looking into the long-term or even overall effects of tax legislation on federal revenues, Congress looks only to annual revenue effects over a five- or ten-year period. Indeed, Congress has bound itself legislatively to focus on this question through statutory budgetary requirements. In contrast, there are no specific constraints regarding the distribution of tax changes, and the basic distributional question being addressed in unquestionably a proper one. In changing a tax system whose history - indeed its constitutional status - is grounded in notions of ability to pay, it is obviously important for policymakers to attempt to know the distributional consequences of proposed changes. However, as with the revenue estimates, the basis for congressional evaluation and decisionmaking regarding distributional issues is seriously flawed. ${ }^{12}$

A comprehensive book on distributional analysis was edited by a former Treasury Department official that solicited papers written by staff of the government agencies responsible for tax distribution analysis (Bradford 1995). Most of the contributing authors are economists who discuss the various methodologies used across different agencies. For example, Barthold, Nunns, and Toder authored a chapter that compared and contrasted the different methodologies employed by the Treasury's Office of Tax Analysis, the Congress' Joint Committee on Taxation and the Congressional Budget Office.

Similarly, another edited volume on the distribution of tax burdens was published that collected what the editors felt were seminal articles over the past forty-years (Fullerton and Metcalf 2003). The Fullerton and Metcalf volume contains over thirty articles that cover early theories on tax incidence, general equilibrium analysis, incidence with imperfect competition, property taxation, incidence in dynamic models and lifetime incidence. These articles are primarily concerned with the proper application of the incidence of tax burdens. The articles do not address whether the current practice of tax distribution analysis is misleading or biased, or how tax distribution tables

\footnotetext{
${ }^{11}$ See, for example: Michael J. Graetz, “Paint-By-Numbers Tax Lawmaking” Columbia Law Review 95 (April 1995): 609; and "The Truth About Tax Reform." University of Florida Law Review 40, no. 4 (Fall 1998).

${ }^{12}$ Michael J. Graetz, “Paint-By-Numbers Tax Lawmaking” Columbia Law Review 95 (April 1995): 609.
} 
are used in the federal tax policy process. Though a short article by Furchtgott-Roth argues that many tax distribution tables are "tailor-made" to produce a particular result in distribution tables, ${ }^{13}$ the general lack of treatment on the use of tax distribution tables in the policy process is a gap in the literature that needs to be filled.

Finally, much of the literature applying tax distribution tables to the analysis of tax policy and on the use of tax distribution to the tax policy process has developed outside peer-reviewed journals. Literature outside peer-reviewed journals includes reports and studies issued by government organizations, ${ }^{14}$ well-renowned think tanks, ${ }^{15}$ or in articles published by professional trade press or news services. ${ }^{16}$

Doctoral dissertations, such as this dissertation, are now starting to emerge that identify the importance distributional analysis plays in the federal tax policy process. One such dissertation (Barry 2004) empirically demonstrates how conventional methodologies fail to accurately account for demographic characteristics and, therefore, provide a misleading picture of equity in the analysis of a proposed change to federal tax policy. While Barry's dissertation is primarily concerned with methodological issues, his research begins to bridge the gap in the literature between methodological considerations and their implications for public policy analysis. As Barry states, "The result of this over-simplified methodology is that lawmakers are presented with a misleading picture of the distribution of taxes, and, therefore, tend to make incorrect assumptions about the fairness of the changes they make to tax law."17 The research being presented in this dissertation fills the gap in the economics literature relating to tax distribution analysis and further bridges the literatures by triangulating on the economics, public finance and political science literatures.

\footnotetext{
${ }^{13}$ See, for example, Diana Furchtgott-Roth, “Abuses of Income Distribution Tables in Tax Policy,” Tax Notes, December 11, 1995.

${ }^{14}$ See, for example: Jason Fichtner, “A Guide to Tax Policy Analysis: Problems with Distributional Tax Tables,” U.S. Congress, Joint Economic Committee (January 2000); "A Guide to Tax Policy Analysis: The Central Tendency of Federal Income Tax Liabilities in Distributional Analysis,” U.S. Congress, Joint Economic Committee (May 2000); "The Misleading Effects of Averages in Tax Distribution Analysis,” U.S. Congress, Joint Economic Committee (September 2003); and "A Comparison of Tax Distribution Tables: How Missing or Incomplete Information Distorts Perspectives,” U.S. Congress, Joint Economic Committee (December 2003).

${ }^{15}$ See, for example: Rudolph Penner, "Searching for a Just Tax System,” Discussion Paper No. 13, The Urban/Brookings Tax Policy Center (January 14, 2004); Leonard E. Burman and David Gunter, "17 Percent of Families Have Stock Dividends,” The Urban/Brookings Tax Policy Center (May 26, 2003; and William G. Gale, “Distribution of Federal Taxes and Income, 1979-2000,” The Urban/Brookings Tax Policy Center (September 29, 2003).

${ }^{16}$ See, for example: William Gale and Peter Orszag, “The President’s Tax Proposal: Second Thoughts,” Tax Notes (January 27, 2003); William Gale, Matthew Hall, and Peter Orszag, "Future Income Tax Cuts From the 2001 Tax Legislation,” Tax Notes (February 17, 2003); and Dan Mastromarco, “What’s So Fair About a Tax on Income?” Tax Notes (October 11, 1999).

${ }^{17}$ John Barry, “Advances in Distributional Analysis,” (Ph.D. dissertation, George Mason University, 2004).
} 


\section{Public Finance}

Public finance is the branch of economics concerned with the income and expenditure of government and the effect of fiscal policies upon the economy in general. The subject of public finance can generally either concentrate on the income side or the expenditure side. As mentioned previously, distribution tables have become ubiquitous to the tax policy debates surrounding major legislative initiatives to change federal income tax law over the past two decades. Published research on the use of distribution tables has primarily focused on methodological issues for properly measuring tax burdens. ${ }^{18}$ However, Hubbard (1993) discusses the "use" of distribution tables in the tax policy process and further explains the importance of the issue for public policy.

According to Hubbard, "The distribution of tax burdens (and government expenditures) is a fundamental question in both public economics and public policy...Tax policy debates among policymakers are grounded in no small part in the policymakers' perceptions of the effects of policy changes on the distribution of economic well-being." ${ }^{\prime 9}$ To further emphasize the importance that tax distribution tables play in the policy process, Hubbard also states that "the higher profile of distribution tables has aroused worries by economists in and out of government that the tables do not necessarily convey the appropriate information (or, in some cases, lack of information) to decisionmakers." 20

Published in the same issue of the National Tax Journal as Hubbard (1993), Auerbach (1993) discusses the importance of tax distribution tables as a policy tool and focusing on the information the tables convey. According to Auerbach,

Revenue and distributional analysis are important tax policy tools supplied by economists and supposedly grounded in economic theory and practice. Yet, as the demands of the process and the stress put on these tools increase, it is important to return to the foundations of these processes, to ask what purposes they are supposed to serve and what information they are intended to convey. ${ }^{21}$

Many of the articles that appeared in the 1993 issue of the National Tax Journal subsequently were published in the previously mentioned edited book by Bradford (1995). However, since then, the literature has not kept pace with how distribution tables are used in the policy process and how different methodologies and different presentations of results influence the way perspectives are defined. ${ }^{22,23}$ The research proposed in this dissertation aims to add to the debate

\footnotetext{
${ }^{18}$ See, for example, the thirty-two journal articles covering the last forty years in, Don Fullerton and Gilbert E. Metcalf, eds., The Distribution of Tax Burdens (Northampton, MA: Edward Elgar Publishing, Inc., 2003).

${ }^{19}$ R. Glenn Hubbard, “On the Use of "Distribution Tables” in the Tax Policy Process," National Tax Journal 46, no. 4 (December 1993): 527.

${ }^{20}$ Ibid.

${ }^{21}$ Alan J. Auerbach, “Public Finance in Theory and Practice,” National Tax Journal 46, no. 4 (December 1993): 525.

${ }^{22}$ However, the trade press and think tanks have published a few articles or commentaries that have added nicely to the debate. See, for example: Rudolph Penner, "Searching for a Just Tax System," Discussion Paper No. 13, UrbanBrookings Tax Policy Center (January 14, 2004); Martin Sullivan, “Zen and the Art of Reading Distribution
} 
in this literature by furthering the discussion on the importance of tax distribution tables to public policy and also how tax distribution tables are used in the tax policy process.

\section{Political Science, Public Policy and Politics - Agenda Setting and ISSUE DEFINITION LITERATURE}

Although tax distribution analysis has not primarily been covered in the political science literature, the proposed research will also ground and connect the treatment of tax distribution analysis in the public finance, economic and tax journals with the political science literature. An appropriate grounding is in the area of "problem definition." As discussed by Rochefort and Cobb (1994), problem definition is the process by which problems and issues are characterized in the political arena.

By drawing upon earlier work on political conflict-oriented theory of politics by Schattschneider (1960) and agenda-setting by Kingdon (1984) and Baumgartner and Jones (1993), problem definition focuses on how the ideas, arguments, convictions, demands, and perceived realities that direct the public's view of an issue define the issue in the political arena. Problem definition as an area of policy analysis is concerned with how issues become identified as public issues and how the issues are framed. Problem definition has been used as a policy analysis tool to study issues such as plant closings (Portz 1994), air transportation policy (Baumgartner and Jones, 1994), and even tax policy (Mucciaroni 1994). However, the use of tax distribution tables in the policy process has yet to be covered using the lens of problem definition or placed in the context as a tool of political strategic management.

Weiss (1989), in an article that appears in the Journal of Policy Analysis and Management, looks at congressional committees and how they use and interpret "analysis." Such "analysis" typically includes information provided by government agencies and interest groups. Weiss points out that "Competing interest groups advance their own arguments, with the accompanying research and analytic support, in order to make their own case."24 Although Weiss does not focus directly on the use of distribution tables, she quotes from one of her congressional staff survey responses about the use of analysis: "Information is used to make a case rather than to help people make up their minds."25

In addition, research by Stone (2002) sets out to demonstrate that "Ideas are at the center of all political conflict. Policy making, in turn, is a constant struggle over the criteria for classification, the boundaries of categories, and the definition of ideals that guide the way people behave."26 Further, Stone describes that how preferences are defined depends partly on how different

\footnotetext{
Tables,” Tax Notes, March 26, 2001; and Leonard Burman, “Treasury’s New Distribution Presentation Analyzed,” Tax Notes, March 26, 2001.

${ }^{23}$ An edited volume along the lines of Bradford (1995) is in the stages of development and is expected to be published by the Heritage Foundation in fall of 2005.

${ }^{24}$ Carol H. Weiss, "Congressional Committees as Users of Analysis," Journal of Policy Analysis and Management 8, no. 3 (1989): 420.

${ }^{25}$ Ibid., 425.

${ }^{26}$ Deborah Stone, Policy Paradox: The Art of Political Decision Making, rev. ed. (New York, NY: W.W. Norton \& Company, Inc., 2002).
} 
choices are presented. Stone's research on how preferences are defined directly ties into the research on distribution analysis in this dissertation.

In political conflict, how an issue is defined can serve as tools used by opposing sides of a political debate to gain advantage. As Nelkin (1975) discusses, participation can be restricted by defining issues and problems along procedural or narrow technical terms that provide technical experts with influence and power in the policy process. Limited participation allows those that control the definition of the issue (in the case of tax distribution tables, those that issue the tables) to have a potentially large impact on not just the framing of the issue but also a large impact on public opinion and ultimately on public policy outcomes.

The area of problem definition is part of the literature on how issues and ideas at the center of political conflict make it onto the national agenda and their ultimate success or failure. Therefore, the research proposed in this dissertation is appropriately grounded in this political science literature.

\section{NICHE IN THE LITERATURE}

Distribution tables have become ubiquitous to the tax policy debates surrounding major legislative initiatives to change tax law. The literature does not adequately address the current importance and role of tax distribution tables in the tax policy process because the literature does not sufficiently deal with tax distribution tables as tools of strategic political management or demonstrate how the inclusion (omission) of different variables and the methodologies applied to the analysis of variables can provide different and misleading information to shape perspectives.

Additionally, no tool of policy analysis yet exists in the literature that can be applied to evaluate tax distribution tables as a method for placing the information contained in tax distribution tables in proper context and further to make transparent the different perspectives that alternative designs and methodologies provide. The research proposed in this dissertation fills that void. Given the prominent role tax distribution tables have come to play in the policy process, it is appropriate that how distribution tables are designed to influence federal tax policy be more fully examined and understood. The research presented here provides a bridge across the literature by triangulating on the economics, public finance and political science literatures. 


\section{CHAPTER 3 - RESEARCH DESIGN}

The focus of this research will be on the different methodologies and presentations of results used in tax distribution tables in the federal tax policy process. The presentation or design of tax distribution tables refers to which variables are included (omitted) from the analysis, while methodologies refer to how the variables are measured. For example, a table might be designed to present a variable on after-tax income, while how income is measured would be considered a methodology issue.

By comparing the different methodological approaches to the definition of key variables, and the different designs of distribution tables, patterns will emerge that demonstrate how distribution tables are used to define the issue and frame the debate. An index of questions is offered as a tool of policy analysis to assist end-users of distribution tables in identifying where and how various distribution tables are misleading.

The research proposed in this dissertation will evaluate the tax distribution tables released by the Department of Treasury, Office of Tax Analysis under the presidential administrations of Bill Clinton (1993-2000) and the first term of George W. Bush (2001-2004). The time period of analysis was chosen due to ease of data availability and to include the most current available data and methods of distribution analysis. Further, the chosen period of analysis covers both a Democratic and Republican presidential administration, as well as congressional control under both parties. Similar coverage will be given to the Joint Committee on Taxation and the Congressional Budget Office, both of the U.S. Congress, under the same time period, allowing for analysis of the congressional organizations under Democratic and Republican control of Congress. The research will also cover the various interest groups and think tanks ${ }^{27}$ that have released tax distribution tables based on microsimulation models into the public domain over the contemporaneous time period through calendar year $2004{ }^{28}$

Data sources for the research proposed in this dissertation include copies of tax distribution tables released by the government agencies and interest groups. Most of the tables are usually available through books, journal articles, archives, the federal record, posted on websites, available by obtaining copies of popular press articles that covered the releases of distribution tables, or from other government sources.

Given that tax distribution tables are generally only produced for major tax bills, the comparative research will cover the five main individual income tax bills from 1993 through 2004. The first four of these bills are identified as major tax bills signed into law by Tempalski (2003), an economist with the Treasury Department, Office of Tax Analysis. These bills are: (1) Omnibus

\footnotetext{
${ }^{27}$ Every attempt has been made to cover all distribution tables released by the primary interest groups and think tanks, as identified by their coverage in national media or through congressional testimony. Examples of such groups include, Brookings, Urban Institute, Citizens for Tax Justice, and the Center on Budget and Policy Priorities. Also note that some major think tanks that regularly publicly issue research or comment on tax policy issues do not necessarily issue tax distribution tables. These organizations are identified where necessary.

${ }^{28}$ A 2004 Congressional Research Service report identifies the public and private organizations that produce tax distribution tables as: Treasury Department, Congressional Budget Office, Joint Committee on Taxation, Tax Policy Center, and the Citizens for Tax Justice / Institute on Taxation and Economic Policy. Jane Gravelle, "Distribution of the Tax Burden Across Individuals: An Overview,” Congressional Research Service, December 13, 2004, 8.
} 
Budget Reconciliation Act of 1993; (2) Taxpayer Relief Act of 1997; (3) Economic Growth and Tax Relief Reconciliation Act of 2001; and (4) Jobs and Growth Tax Relief and Reconciliation Act of 2003. A fifth (5) bill (Working Families Tax Relief Act of 2004) was recently passed by the Congress in September 2004. ${ }^{29}$ Descriptions of the main provisions included in these bills are discussed the Chapter 7.

Distribution analyses are occasionally conducted not only on specific tax bills, but on the current distribution of tax burden. The Joint Committee on Taxation, Congressional Budget Office and the Tax Policy Center have performed such analyses. As a sixth (6) point of comparative analysis, this research will also compare those distribution tables for the time period under analysis.

As mentioned, the dissertation proposed a method for evaluating tax distribution tables. An index of questions is offered as a new tool of policy analysis, an index I have created and termed the "Tax Distribution Table Scoring Index" (TDTSI). The TDTSI balances the different perspectives presented via tax distribution tables and assists users of tax distribution tables in evaluating and uncovering the various manners in which tax distribution tables can be designed to mislead and influence tax policy perspectives. This research not only advances the current practice of tax distribution analysis but also enhances the study of public policy by gaining a better understanding of the influence tax distribution tables play in the federal tax policy process.

\section{A Tax Distribution Table Scoring Index as a Tool of Policy Analysis}

A tax distribution table purports to show how various groups are affected from a proposed change to tax policy. The resulting analysis either shows that a proposed tax policy is (1) distributional neutral, meaning that every group benefits from a tax cut (or shares the burden of a tax increase) equally; or (2) that some groups benefit (or bear the burden) unequally over others. Whether or not a given policy proposal is "fair" depends on one's viewpoint of fairness. Generally, tax policy advanced by conservatives on the right has been concerned with lowering tax burdens in general, or across the board, while tax policy supported by liberals on the left has sought to redistribute more of the burden of taxation onto those with upper-incomes.

Terms such as liberal or left and conservative and right are common descriptions used in political dialogue. Poole and Rosenthal state "such labels are useful because they quickly furnish a rough guide to the positions a politician is likely to take on a wide variety of issues."30 Associations with these labels are relatively consistent over time. With respect to tax policy, liberals are more likely to favor policies that result in the redistribution of wealth and/or after-tax income. Conservatives are more likely to favor consumption taxes over income taxes and be concerned with the share of taxes paid by different groups and who bears the burden of paying for government.

\footnotetext{
${ }^{29}$ Legislation to extend the provisions of EGTRRA 2001 \& JGTRRA 2003 was passed in September 2004, as the Working Families Tax Relief Act of 2004. It does not appear that distribution tables were prepared for this piece of legislation by OTA or JCT, though some were prepared by interest groups.

${ }^{30}$ Keith T. Poole and Howard Rosenthal, "Patterns of Congressional Voting," American Journal of Political Science 35, no. 1 (February 1991).
} 


\section{As former Director of the Congressional Budget Office Rudy Penner writes:}

Liberals argue that a tax policy change is fair if it reduces discrepancies in the distribution of after-tax income. Moderate conservatives focus on the share of the cost of government borne by different income groups and argue that all is well as long as a tax change raises the share of the total tax burden borne by the most affluent. Many pure conservatives favor a flat tax, and some believe that the base of the tax should be consumption rather than income. Nevertheless, they believe in protecting lower income groups with large exemptions. They just don't care much about the distribution of economic resources among the middle class, the moderately rich, and the filthy rich.

Pure conservatives' ultimate policy goals are clearer than those of liberals and moderate conservatives. If liberal arguments were taken to an extreme, they would imply an egalitarian society - at least as measured by the distribution of after-tax income. The moderate conservatives' argument would imply that the very highest income earners would eventually bear 100 percent of the total tax burden. $^{31}$

If liberals and conservatives do indeed tend to exhibit these traits, then logically presidential administrations, advocacy groups and think tanks that are considered left-liberal or rightconservative reveal similar characteristics and, therefore, should have similar tax policy positions. Therefore, if distribution tables are less a tool of objective policy analysis and more a tool of political strategic management, then patterns should emerge that demonstrate how different methodologies, content and presentation of results define and shape how the perceived fairness of a tax policy is defined or viewed. The purpose of this dissertation research is to provide such a demonstration and further demonstrate how the Tax Distribution Table Scoring Index (TDTSI) I developed, composed of 10 questions, can serve as a policy tool for evaluating tax distribution tables and illuminating elements of bias.

For purposes of this research, the ten questions elicit affirmative responses if the variable under analysis tends to favor liberal tax policy views. Tables that provide affirmative scores for all ten questions would score a 10 , or $100 \%$, and would indicate that the distribution table under analysis is designed to present information that advances liberal tax policy positions (such as redistributing after-tax income) or to oppose conservative tax policy positions. Anything less than 10 , or $100 \%$, is a degree of being "less liberal."

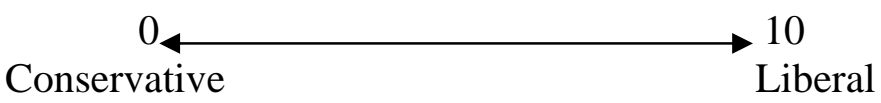

The main benefit of this method is its simplicity. The responses are summed and the result can be placed on an ordinal scale from 0 to 10. The implication is that a table scoring a "7" presents more "liberal" information than a table scoring a " 5 ." The scale is not intended to be an interval scale, but rather an ordinal scale where 10 is more than 1 but not necessarily ten times more.

\footnotetext{
${ }^{31}$ Rudolph G. Penner, “Searching for a Just Tax System,” Discussion Paper No. 13, Urban-Brookings Tax Policy Center (January 2004).
} 
A second approach to the TDTSI is to measure the left-leaning and right-leaning score separately using the formula below. In this case,

Preference $_{\mathrm{L}}=$ Preference $_{\mathrm{L}}$ / Preference Total$_{\text {; }}$ and Preference ${ }_{\mathrm{R}}=$ Preference $_{\mathrm{R}}$ / Preference Total $_{\text {. }}$

Where Preference ${ }_{L}$ is defined as the total number of questions coded as having liberal characteristics, Preference $\mathrm{R}$ is defined as the total number of questions coded as having conservative characteristics and Preference Total is the combination of the two.

While this second method provides the same result as the first, it also provides percentage scores for both "liberal" and "conservative" characteristics. A table with a score of "7" using the first method would have a score of $70 \%$ liberal and 30\% conservative. The benefits of this second method are similar to the first, with the additional benefit of showing scores for both liberal and conservative characteristics. However, users of this second method may tend to mistakenly perceive that this method results in an interval scale where a score of $60 \%$ liberal would be twice as liberal as a table with a score of $30 \%$ liberal. Again, the scale is not intended to be an interval scale, but rather an ordinal scale where 10 is more than 1 but not necessarily ten times more.

A third TDTSI scoring measure would subtract the number of left-leaning characteristics from the number of right-leaning characteristics, and divide the result by the total number of questions used in the coding scheme. For example:

Preference $_{L R}=\left(\right.$ Preference $_{L}-$ Preference $\left._{R}\right) /$ Preference $_{\text {Total }}$

Structured in this manner, a score closer to 1 would be fully "liberal” and a score of "-1" fully "conservative." The ordering of Preference ${ }_{L}$ and Preference ${ }_{R}$ could be reversed to make a score of 1 fully conservative. Laver and Garry used a similar coding scheme (2000). ${ }^{32}$

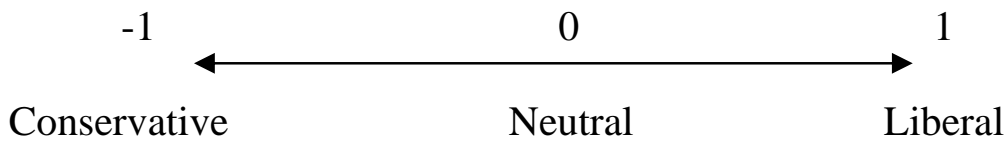

A possible benefit of using this third method is that zero becomes a middle point, suggesting that a table with a score of " 0 " is politically balanced, or at least the distribution table is not designed to bias toward a given tax policy position. Although a weighted scale could be devised, this author does not think it advisable, since the choice of which questions to weight and the weighting scheme itself would introduce some measure of bias that cannot be supported in the literature at this time. A weighting scheme could be a good addition to the literature for future research. Again, the scale is not intended to be an interval scale, but rather an ordinal scale.

As previously stated, the framing of the questions in the analysis can just as easily be reversed to focus on conservative preferences. However, as Penner states, since pure conservatives are not interested in distribution issues as a measure of the fairness of a tax policy, while liberals are, I have decided to focus on identifying liberal characteristics of tax distribution tables.

\footnotetext{
32 Michael Laver and John Garry, “Estimating Policy Positions from Political Texts,” American Journal of Political Science 44, no. 3 (July 2000): 628.
} 
Provided below are the questions that compose the basis for the new tool of policy analysis. These questions are based on the key variables identified in the literature that impact the results of distributional analysis (Hubbard 1993; Cronin 1999; Fichtner 2000; and Barry 2004). For example, Hubbard (1993) describes the "essential elements" of tax distribution tables as: which taxes are included; definition of income; incidence assumptions; measure of tax burden used; and how temporary tax provisions are treated. Barry (2004) identifies that distribution analysis depends on "seven primary categories of information: taxes included; time period of analysis, unit of analysis, income measure, incidence assumptions, presentation of results including tax burden measure, and data source(s) used.”

In some manner or another, the questions provided below relate to at least one of the elements or categories listed in the literature. Further, the questions in the index also deal with the design of tax distribution tables and the methodological approach applied. Given that the primary research interest of this dissertation centers on how the presentation of data can contribute to the perception of the fairness of a proposed tax policy, most of the ten questions in the index fall into the category of "presentation of results," which is also referred to as the "design" of tax distribution tables.

Each question in the TDSI is equally weighted. Although a weighted scale could be devised, this author did not think it advisable to develop a weighted-index at this stage in the research. First, a non-weighted TDTSI needs to be evaluated first and the results evaluated by the research community. Second, the choice of which questions to weight and the weighting scheme itself would introduce some measure of bias that cannot be supported in the literature at this time. Hopefully, this dissertation research will provide the building blocks for the necessary support in the literature for future research on a weighted-TDTSI.

While the validity of the ten questions can themselves be questioned (are the categories exhaustive; are there too many; too few; not the right questions; etc.), the content validity of each question is tied when possible to the literature, including this author's previous research on the subject matter. $^{33}$ Additionally, to quote Deborah Stone's response as to whether or not the categories used in her research were exhaustive, "I can only plead the quintessential political defense: I had to draw the line somewhere."34

\section{VALIDITY ISSUES}

The questions proposed for the index are currently structured to provide a binary response. Since the index is a tool of policy analysis for evaluating tax distribution tables, some discussion as to why each of these questions is relevant and important is required. Any observed patterns in the data are discussed in Chapter 8 dealing with the summary of results.

\footnotetext{
${ }^{33}$ See, for example: Jason Fichtner, “A Guide to Tax Policy Analysis: Problems with Distributional Tax Tables,” U.S. Congress, Joint Economic Committee (January 2000); “A Guide to Tax Policy Analysis: The Central Tendency of Federal Income Tax Liabilities in Distributional Analysis,” U.S. Congress, Joint Economic Committee (May 2000); “The Misleading Effects of Averages in Tax Distribution Analysis,” U.S. Congress, Joint Economic Committee (September 2003); and “A Comparison of Tax Distribution Tables: How Missing or Incomplete Information Distorts Perspectives,” U.S. Congress, Joint Economic Committee (December 2003).

${ }^{34}$ Deborah Stone, Policy Paradox: The Art of Political Decision Making, rev. ed. (New York, NY: W.W. Norton \& Company, Inc., 2002), 14.
} 
A valid measure is generally one that measures what it is intended to measure. ${ }^{35}$ For each question in the proposed index, the question then is: does an affirmative response (coded as a “ 1 ”) increase the likelihood that a tax distribution table is issued by an organization advancing liberal tax policy? Similarly, for each question: does a response coded as a "0" increase the likelihood that a tax distribution table is issued by an organization advancing conservative tax policy? A reliable measure is one that yields similar results when used among different groups. ${ }^{36}$ It is assumed that the proposed index is applicable to any tax distribution table under any time period of analysis. The following discussion is designed only to address whether there appears to be enough face validity ${ }^{37}$ at this stage of the dissertation research. In other words, does the literature support the use of the following measures as a starting point for the dissertation research?

The following discussion deals with the validity of the variables or measures used in the distribution tables themselves. Another validity issue concerns whether the different results that are presented in tax distribution tables affect the perspectives end-users of distribution tables perceive. To demonstrate this validity, the comparative analysis (Chapter 5) of the dissertation demonstrates how different distribution tables were perceived or portrayed in the media and in statements made by policymakers (through press releases, floor speeches, etc.).

Lastly, every attempt has been made to make this research as objective (as opposed to subjective - and in the sense of the concept of reliability) as possible. According to Hardy, Harley and Phillips (2004), objective research means "that the analytic categories are defined so precisely that different coders may apply them and obtain the same results...”38

1. Is a measure of income used other than cash income or Adjusted Gross Income (AGI)?

Measurement of income has been identified as a core variable in distribution analysis by both Cronin (1999) and Barry (2004). The importance of measurement of income has been demonstrated in this author's own research (Fichtner 2000). Almost every distribution table includes some measure of income. Hence, it is necessary to include some question pertaining to income in the index I am proposing.

Since liberal tax policy preferences are focused on redistributing income (Penner 2004), this question is designed to address whether alternate measures of income (something other than AGI) are used to make a tax policy proposal appear less redistributive than if income were

\footnotetext{
${ }^{35}$ Elizabethann O’Sullivan (et al), Research Methods for Public Administrators, $4^{\text {th }}$ ed. (New York, NY: Addison Wesley Longman, Inc., 2003), 118.

${ }^{36}$ Elizabethann O'Sullivan (et al), Research Methods for Public Administrators, $4^{\text {th }}$ ed. (New York, NY: Addison Wesley Longman, Inc., 2003), 107-116.

${ }^{37}$ Face validity is defined by O’Sullivan as “A measure that appears to be operationally valid. Methodologists do not define it as a validation technique, and at best if offers only superficial evidence of a measure's

appropriateness.” Elizabethann O’Sullivan (et al), Research Methods for Public Administrators, $4^{\text {th }}$ ed. (New York, NY: Addison Wesley Longman, Inc., 2003), 486.

${ }^{38}$ Cynthia Hardy, Bill Harley and Nelson Phillips, “Discourse Analysis and Content Analysis: Two Solitudes?”

Qualitative Methods (Spring 2004): 19.
} 
measured based on AGI. Research by Cronin (1999) and Fichtner (2000) have empirically demonstrated how measures of income other than AGI can have this effect.

2. Is the unit of analysis families or households?

Similar to the measurement of income, defining the unit of analysis is another important consideration (Hubbard 1993, Cronin 1999, Fichtner 2000, and Barry 2004). The unit of analysis is related to the measurement of income because income can be measured on an individual, family, household, or tax return level. A family or household unit of analysis is a proxy for an economic unit, while a tax return basis corresponds to current income tax reporting (Hubbard 1993).

If a unit of analysis other than tax returns is used, the result of such a broad-based measure will be less "units." Further, additions of income move families up the income ladder and give the perception that reductions in tax liabilities that would appear to benefit the middle-class under a tax return unit of analysis instead benefit higher income taxpayers (Fichtner 2000). Since liberal tax policy preferences are focused on redistributing income (Penner 2004), this question is designed to address whether alternate units of analysis are used to make a tax policy proposal appear less redistributive than if the unit of analysis is based on tax returns.

3. Is the percent change in after-tax income included in the analysis?

If redistribution of income is a goal of liberal tax policy then an index question on whether or not after-tax income is included in a distribution table is necessary. Since, on a static basis, changes in income do not affect before-tax income, the primary way of measuring whether a tax change furthers redistributive goals is to present a variable on "after-tax income" in a tax distribution table. After-tax income has been identified as the preferred method of analysis to study the incidence of a tax change by some scholars in the literature (Cronin 1991; Gravelle 2003; and Gale and Orszag 2004).

4. Is the percent of total tax change included in the analysis?

Penner (2004) points out that liberal tax policy is concerned with redistributing after-tax income. In tax policy, a primary way of redistributing income is through the tax code. As Fichtner (2000) has demonstrated, focusing on the percent of total tax change has the effect of making distributionally neutral tax cuts appear regressive. Similar observations were made by Davis (1991).

5. Are payroll taxes included in the analysis of taxes paid?

To measure a change in taxation it is first necessary to decide which taxes to include in the analysis. Since many tax filers that reside in the bottom quintiles pay little if any federal income tax, the likely outcome of any income tax reduction proposal is that it will not appear to provide significant benefits to low-income households and the progressive nature of the tax system will be understated (Fichtner 2000). Including payroll taxes in the tax base has the effect of 
increasing the share of taxes paid by low-income groups, relative to federal income taxes alone, and increasing the share of income paid in taxes.

6. Is the number of taxpayers residing within the income categories?

Rather than directly affecting the outcome of the analysis, this question is concerned with transparency and whether or not important information is being disclosed. Observations in a tax distribution table are typically categorized by income (regardless of income measure used). Categories can be either an income range or quintiles. Quintiles, by definition, result in five equal categories, so it is only necessary to disclose the total number of observations when using quintiles. However, if income ranges associated with each income category are used, disclosure of the number of taxpayers by group is necessary. Distribution tables that use income ranges and do not disclose the number of observations per group can be misleading by giving the impression that each grouping is made up of the same number of observations and possibly making any comparisons between the income groups misleading (Fichtner 2000).

\section{Are ranges of income associated with each income category omitted?}

Similar to Question \#5, Question \#6 is more focused on transparency and unveiling an illusion of precision in tax distribution tables. A progressive tax system is one in which higher income taxpayers pay a higher percentage of their income in taxes. In order to effectively evaluate whether a current tax structure, or a change in taxation, is progressive or regressive, it is necessary to disclose the income ranges associated with each income grouping (Fichtner, 2000).

\section{Are ranges of tax liability associated with each income category omitted?}

Similar to Question \#6, Question \#7 is focused on transparency and unveiling an illusion of precision in tax distribution tables. A progressive tax system is one in which higher income taxpayers pay a higher percentage of their income in taxes. In order to effectively evaluate whether a current tax structure, or a change in taxation, is progressive or regressive, it is necessary to disclose the range of tax liability for each income grouping (Fichtner, 2000).

\section{Are the current and proposed percent of taxes paid for each income category omitted?}

In order to evaluate whether or not a change to tax policy would result in a more or less progressive tax system, it is necessary to disclose the current and proposed levels of taxation. Organizations issuing tax distribution tables and wanting to suppress information that a tax reduction can increase progressivity despite providing more nominal dollars in tax reduction to higher income taxpayers might omit this important information (Fichtner 2000).

\section{Are the current and proposed tax rates for each income category omitted?}

In order to evaluate whether or not a change to tax policy would result in a more or less progressive tax structure, it is necessary to disclose the current and proposed effective tax rates for each income category. Organizations issuing tax distribution tables and wanting to suppress information that a tax reduction can increase progressivity despite providing more nominal 
dollars in tax reduction to higher income taxpayers might omit this important information (Fichtner 2000). 


\section{Chapter 4 - Fundamental Problems Associated With TAX DISTRIBUTION TABLES}

Before proceeding to the comparative analysis chapter of the dissertation research and demonstrating how tax distribution tables are used in the tax policy process as tools of strategic management, it is important that readers have an understanding of what exactly constitutes a tax distribution table. Further, in order to fully appreciate the nuances of how different presentations of data and methodological approaches to distributional analysis can affect perspectives it is also important that readers be exposed to some of the fundamental problems associated with tax distribution tables. This chapter provides such necessary information.

\section{THE Distribution TABLE}

A distribution table can be deceptively simple. Generally, in the left-hand column are income categories classified by either dollar cut-offs, such as, $\$ 0$ - $\$ 10,000, \$ 10,000$ - $\$ 20,000, \$ 20,000$ $\$ 30,000$, etc., or divided into percentile groupings such as, lowest quintile, second quintile, third quintile, fourth quintile, and highest quintile. Additional columns provide information about the number of observations, income levels, taxes paid, etc., for each income category. Usually, the table provides information pertaining to the changes in taxes after the proposed tax legislation is enacted. The primary focus of tax analysis is the increases and decreases in taxes under current law in comparison to after the proposed tax legislation. Table 4-1 provides an illustration of a simple distribution table relating to a hypothetical proposal to reduce individual taxes:

\begin{tabular}{|c|c|c|c|c|c|}
\hline \multirow{4}{*}{ Income Category } & \multicolumn{4}{|c|}{ Table 4-1. Illustration of a Tax Distribution Table } & \multirow{4}{*}{$\begin{array}{c}\text { Average Tax Change } \\
\$\end{array}$} \\
\hline & \multirow{2}{*}{\multicolumn{2}{|c|}{ Change in Federal Taxes }} & \multicolumn{2}{|c|}{ Effective Tax Rate } & \\
\hline & & & Present Law & Proposed Law & \\
\hline & \$ (millions) & Percent & Percent & Percent & \\
\hline Less than $\$ 10,000$ & -20 & -0.2 & 7.1 & 7.0 & -300 \\
\hline$\$ 10,000$ to $\$ 20,000$ & -365 & -1.0 & 8.1 & 8.0 & -400 \\
\hline$\$ 20,000$ to $\$ 30,000$ & $-1,300$ & -1.5 & 15.2 & 15.0 & -500 \\
\hline$\$ 30,000$ to $\$ 40,000$ & $-2,150$ & -1.9 & 17.6 & 17.3 & -750 \\
\hline$\$ 40,000$ to $\$ 50,000$ & $-2,750$ & -2.1 & 19.3 & 18.9 & $-1,100$ \\
\hline$\$ 50,000$ to $\$ 75,000$ & $-7,200$ & -2.3 & 21.2 & 20.7 & $-1,500$ \\
\hline$\$ 75,000$ to $\$ 100,000$ & $-6,600$ & -2.4 & 23.9 & 23.2 & $-2,000$ \\
\hline$\$ 100,000$ to $\$ 200,000$ & $-8,100$ & -2.2 & 26.2 & 25.5 & $-3,500$ \\
\hline$\$ 200,000$ and over & $-13,500$ & -3.1 & 29.2 & 27.6 & $-5,000$ \\
\hline Total, all taxpayers & $-\$ 41,985$ & $-2.4 \%$ & $22.2 \%$ & $21.5 \%$ & $-\$ 650$ \\
\hline
\end{tabular}

In viewing the results displayed in the second column, it is quite clear in this example that all taxpayer groups would receive a reduction in tax. The lowest group receives a total reduction in their tax of \$20 million and the highest group receives a total reduction of $\$ 13.5$ billion. The third column shows the reduction in terms of percentages. The lowest group receives a 0.2 percentage reduction in tax, while the highest group receives a 3.1 percentage reduction. The fourth and fifth columns display each group's effective tax rate under present law and after the legislation, respectively. All income groups benefit from a lower effective tax rate under the 
proposed legislation. The last column displays the dollar amount of the average tax cut that each member in an income category might expect to receive.

Since every income group benefits, a cursory review of the above table might lead readers to conclude that the tax proposal is beneficial for all. However, some might come to completely different conclusions. These readers might conclude that the tax legislation is not fair to the lowest income group, since the highest income group receives 32 percent of the total benefit ( $\$ 13.5$ billion / $\$ 42.0$ billion) while the lowest income group receives less than one-half percent of the total benefit ( $\$ 20$ million / $\$ 42.0$ billion). These readers might also consider the tax legislation unfair because the highest income group receives an average tax reduction of $\$ 5,000$, while the lowest income groups receive a reduction of $\$ 300$.

However, the problem with this perspective is that these numbers reflect more about the impact of the current tax system than the tax change under consideration. In other words, in most cases such statistics primarily reflect the distribution of tax payments under the tax code before the tax change takes place. The more progressive the current tax code, the more regressive any subsequent tax change can be made to appear. What is presented as a measure of the tax change is in reality a statistical mirage that mainly reflects the progressivity of the current tax system.

Table 4-1 actually provides insufficient information from which to draw informed conclusions as to the merits of the proposed tax legislation. For example, this table does not show the current amount of taxes that each income group pays. For purposes of illustration, assume that the lowest income group currently pays no tax at all, while the highest income group pays 50 percent of the total tax collected. Then, based on a different measure of fairness, it could be argued that the highest income group should receive a commensurate amount of the total tax reduction and, therefore, the proposed 32 percent ( $\$ 13.5$ billion / $\$ 42.0$ billion) is unfair to the upper income group.

Additionally, Table 4-1 does not explicitly indicate how many taxpayers make up each income group, although this can be mathematically derived by dividing "Change in Federal Taxes" by "Average Tax Change." Additional information is also necessary to effectively evaluate the proposed tax legislation, such as what items are included in income, what types of taxes are being included (excluded), and over what time horizon the effects are being measured.

\section{The ILlusion OF PRECISION}

Distribution tables are constructed based on data sources that sample parts of the population to make inferences about the population at large, not data sources that count the entire population like a census. Furthermore, many economic and mathematical assumptions are relied upon in order to fashion distribution tables. The end result produces tables which often purport to consist of absolute numbers but instead present a false sense of precision. Despite the appearance of precision conveyed by changes expressed down to one or even two decimal places, the reality is that significant problems usually are just below the surface.

Reading Table $4-1$, a taxpayer that falls into the $\$ 30,000$ to $\$ 40,000$ income range could reasonably expect that their tax cut for the year would be $\$ 750$. Not $\$ 400$ or $\$ 300$, or even an 
unspecified amount somewhere between $\$ 700$ and $\$ 800$. As Yale University law professor and former Treasury Deputy Assistant Secretary for tax policy (under President George H.W. Bush) Michael J. Graetz writes, "[t]he current practice of fashioning tax legislation to achieve a particular result in a distribution table creates the illusion of precision when such precision is impossible." 39 It is statistically possible, based on averages, that some taxpayers would receive no tax cut or even face a tax increase.

Distribution tables provide averages of certain tax data of all the taxpayers identified within a given income category. It is well known to most taxpayers that tax liabilities often differ among families with the same income. This can be because of family size, filing status, whether a family itemizes their deductions or elects to take the standard deduction, whether a family pays a mortgage on their home and deducts the interest expense or rents, the nature of a family's income and other factors. Additionally, some families are more aggressive at reducing their tax liabilities than others. For example, this can be done legally by contributing to a 401(k) plan, an individual retirement account or a medical savings account.

Additionally, the dispersion of taxpayers within an income group is impossible to determine from the information presented in tax distribution tables. Do most of the taxpayers within the $\$ 20,000$ to $\$ 30,000$ income range lie closer to $\$ 20,000$ or to $\$ 30,000$ ? All other things being equal, and from the information presented in Table 4-1, it would be expected that a taxpayer with income closer to $\$ 30,000$ would have a higher tax liability, and subsequently should receive a greater tax cut, than a taxpayer with income closer to $\$ 20,000$. Yet this is not necessarily the case, as will be discussed in further detail later in this chapter. Similar problems exist presenting other information, such as the percent change in after-tax income and tax rates.

Furthermore, the use of averages can be an inappropriate measure of central tendency because extreme outlying data points can skew the average toward a higher number. Central tendency is a summary number used to represent several numbers. Instead of the average, the median, or middle value, can be presented. For example, consider the five salaries of a company listed in Table 4-2:

\begin{tabular}{|l|r|}
\hline \multicolumn{2}{|c|}{ Table 4-2. How Averages Can Misrepresent Central Tendency } \\
\hline \multicolumn{1}{|c|}{ Job Position } & \multicolumn{1}{c|}{ Annual Income } \\
\hline CEO & $\$ 1,000,000$ \\
\hline Attorney & $\$ 70,000$ \\
\hline Systems Administrator & $\$ 60,000$ \\
\hline Economist & $\$ 50,000$ \\
\hline Secretary & $\$ 40,000$ \\
\hline \hline Average & $\$ 244,000$ \\
\hline Median & $\$ 60,000$ \\
\hline
\end{tabular}

The average of these five salaries is $\$ 244,000$. The median value is $\$ 60,000$. In this instance, and in any situation where extreme outliers can skew the average, the median is a better indicator

39 Michael J. Graetz, “Distributional Tables, Tax Legislation, and the Illusion of Precision,” in Distributional Analysis of Tax Policy, ed. David F. Bradford (Washington, DC: AEI Press, 1995). 
of the central tendency because the CEO's salary is an extreme outlier causing the average to lie far from the other four salaries. For example, billionaires such as Bill Gates and Warren Buffet should reside in the upper most income category of any distributional tax analysis. Their incomes alone would be enough to skew any average income measure. Due to this statistical fact, most official government income data provide the median as a measure of central tendency or provide the median along with the average. The use of averages in distribution tables hides information relating to the dispersion and central tendency of the data from the public, further clouding the ability to make sound decisions about tax policy.

\section{WHAT Is INCOME AND Who ARE THE Rich?}

According to the Internal Revenue Service (IRS), to rank in the top 10 percent of individual tax returns for 2000, a taxpayer ${ }^{40}$ needs to report an adjusted gross income amount of $\$ 92,144 .^{41}$ However, distributional tax tables released by the Clinton Administration's Department of Treasury's Office of Tax Analysis defined the top quintile (the top 20 percent, not 10 percent) of families as having an income of at least $\$ 100,767 !^{42}$ This raises the question of how it is mathematically possible that the income level needed to be included in the Treasury top 20 percent is almost 10 percent higher than the income amount needed to be included in the IRS top 10 percent. The answer lies in the details of what the Treasury considers "income."

To the average citizen, "income" is anything on which they have to pay tax. Every year, taxpayers fill out their Form 1040 and list their sources of income on which they owe tax. Such sources of income are:

- $\quad$ wages, salaries, tips;

- interest;

- dividends;

- taxable refunds;

- $\quad$ personal business;

- capital gains;

- rental income, royalties, trust, partnerships;

- farm income;

- unemployment compensation; and

- certain taxable portions of Social Security. ${ }^{43}$

The sum of all income sources defines a taxpayer's total income. Certain adjustments to total income, such as contributions to an IRA (Individual Retirement Account), MSA (Medical Savings Account) and student loan interest deductions, are subtracted from total income to arrive

\footnotetext{
${ }^{40}$ For IRS statistical purposes, the term "taxpayer" refers to the filing unit on a tax return. Individual taxpayers filing under the "single" status with an AGI of $\$ 50,000$ are ranked the same as a married couple with two children filing under the "married filing jointly" status with the same \$50,000 AGI.

${ }^{41}$ Internal Revenue Service, Statistics of Income Bulletin, Spring 2004 (Washington, D.C, 2004).

${ }^{42}$ Department of the Treasury, Office of Tax Analysis, Distribution of Income and Federal Taxes Under Current Law (July 21, 1999). The $\$ 100,767$ figure presented by the Treasury is for year 2000 income levels.

${ }^{43}$ For more information, see: Internal Revenue Service, Your Federal Income Tax and Form 1040. U.S. Individual Income Tax Return. 1998 Tax Guide (Pub. 17).
} 
at a taxpayer's Adjusted Gross Income (AGI). AGI can be located by any taxpayer by taking it right off last line on the front page of their Form 1040. The concepts of total income or AGI are used by most citizens when they think of "income." It is from this base that taxpayers make their decisions regarding whether or not they can afford a house, a new car, spend money on new clothes, or go on a vacation.

Since current tax policy can be confusing enough (the complete Internal Revenue Code is more than 21 megabytes in size, and contains more than 2.8 million words; printed 60 lines to the page, it would fill almost 6,000 letter-size pages ${ }^{44}$ ), the government should help to simplify the tax policy debate by using a measure of income that is readily understandable to typical Americans -- AGI. However, AGI is not what the Treasury Department's Office of Tax Analysis used under President Clinton. The Treasury Department used an income concept called "Family Economic Income."

The Treasury Department's "Family Economic Income” (FEI) concept is an attempt to measure income based on a concept that economists refer to as the Haig-Simons income concept. The Haig-Simons income concept defines income as the "total value of rights exercised in the market, together with the accumulation of wealth in that period." 45 Unlike the tangible dollar amounts that make up AGI, the theoretical Haig-Simons income concept is measured by adding to AGI such items as in-kind income (e.g., cash transfers and food stamps), imputed income from durable goods consumption (e.g., imputed rental income from an owner-occupied home), and accrued (i.e., unrealized) capital gains.

Henry Simons (of the aforementioned Haig-Simons income concept) recognized the great difficulties with the valuation of imputed sources of income. He readily acknowledged this problem when he stated: "Thus, every calculation of income depends upon 'constructive valuation' i.e., upon highly conjectural estimates made, at best, by persons of wide information and sound judgment." 46 Upon close inspection, the Treasury methodology demonstrates that this is indeed the case. ${ }^{47}$

No one single data source (census or survey) currently exits that contains all of these variables. The following items are imputed to create a broader measure of income by use of statistical inference. Items added to AGI to arrive at the FEI concept include:

\section{1. tax-exempt interest;}

\footnotetext{
${ }^{44}$ U.S. Tax Code On-Line. Available on-line at: http://www.fourmilab.ch/ustax/ustax.html

${ }^{45}$ Robert Murray Haig, “The Concept of Income: Economic and Legal Aspects,” in The Federal Income Tax, R.M. Haig (New York: Columbia University Press, 1921); and Henry C. Simons, Personal Income Taxation: The Definition of Income as a Problem of Fiscal Policy, (Chicago: University of Chicago Press, 1938).

${ }^{46}$ Henry C. Simons, Personal Income Taxation: The Definition of Income as a Problem of Fiscal Policy, (Chicago: University of Chicago Press, 1938), 56. (Emphasis added).

${ }^{47}$ Since currently there is no single data source available (census or survey) that contains all of the variables necessary to compute a Haig-Simons income, the Treasury Department must create a data set with such information by combining multiple data sources, based on different sample designs, and create data where none existed before. The process of imputing data and combining survey data based on different sampling designs creates statistical problems. These issues are addressed at the end of this chapter in the section titled "Statistical Accuracy and Reliability Combining Data Sets of Different Sample Designs.”
} 
2. employer contributions for health plans, pension plans, and life insurance, as well as deductible purchases of health insurance by the self-employed;

3. employer's share of FICA tax;

4. workers' compensation;

5. nontaxable Social Security benefits;

6. deductible contributions to IRAs and 401(k)s;

7. welfare payments, food stamps, child support, and certain veterans' benefits;

8. net operating losses carried over from previous years;

9. accrued earnings on pension and individual retirement arrangements;

10. employer contributions for other fringe benefits, including military benefits;

11. inside buildup of life insurance;

12. imputed rental income from owner-occupied housing net of costs such as mortgage interest, property tax, and depreciation;

13. pre-tax corporate profits allocated to individuals based on ownership of shares (both directly and through pension holdings);

14. nontaxable pension benefits;

15. excluded income of U.S. citizens living abroad;

16. alternative minimum tax (AMT) preferences;

17. unreported income; and

18. income from people who don't file tax returns. ${ }^{48}$

Also, the Treasury excludes from its FEI concept in-kind transfers such as Medicare and Medicaid, which often benefit middle and lower income groups. The Treasury's justification for excluding Medicare and Medicaid is based both on "the difficulty of assigning a value of benefits to the recipient, and the difficulty of properly identifying recipients." 49 However, the Treasury Department would face similar problems with the difficulty in imputing values for unreported income, income from people who do not file tax returns and rental income from owner-occupied housing. Furthermore, the Treasury Department aggregates the income of all tax filers in a household into a single-family unit. This means that the income of dependents that file tax returns is added to the income of the primary taxpayers. Additionally, any imputed data variable will contain some measurement error. Measurement error results when a variable can't be measured accurately or when it is inherently unmeasurable. Errors in measuring variables create serious statistical problems. ${ }^{50}$

Many economists and statisticians will argue that one of the greatest problems encountered working with sample data is the fact that many data are poor. A famous quotation by Josiah Stamp, a former President of the Bank of England, recounts:

The Government are (sic) very keen on amassing statistics - they collect them, add them, raise them to the nth power, take the cube root and prepare wonderful

\footnotetext{
${ }^{48}$ James R. Nunns, "Distributional Analysis at the Office of Tax Analysis," in Distributional Analysis of Tax Policy, David F. Bradford (Washington, DC: The AEI Press, 1995); and Letter from the Joint Committee on Taxation, Chief of Staff Lindy Paull to Representative Jim Saxton, June 1999.

49 Julie-Anne Cronin, “U.S. Treasury Distributional Analysis Methodology,” Department of the Treasury, Office of Tax Analysis, OTA Paper 85 (September 1999).

${ }^{50}$ Peter Kennedy, A Guide to Econometrics ( $3^{\text {rd }}$ Edition) (Cambridge, MA: The MIT Press, 1992), 3 and 137.
} 
diagrams. But what you must never forget is that every one of those figures comes in the first instance from the village watchman, who just puts down what he damn pleases. ${ }^{51}$

Furthermore, in an apparent reference to the Stamp quote, noted econometrician Peter Kennedy, addressing the problem of imputed values, states:

The errors-in-variables problem is concerned with the implication of using incorrectly measured variables, whether these measurement errors arise from the whims of the village watchman or from the use by econometricians of a proxy variable in place of an unobservable variable suggested by economic theory. ${ }^{52}$

The FEI income concept is a broader measure of income than AGI. Generally (and especially with FEI), the broader the income measure, the greater the income imputed to an individual or family. If families or individuals are classified by a dollar value of income, a broader income measure (FEI) will show a larger number of families in the upper income categories relative to a narrower definition (AGI). Additionally, the use of an FEI income concept can have the effect of moving families or individuals into different income quintiles than based on AGI (movement can be up or down). In other words, a family that might be in the $3^{\text {rd }}$ income quintile based on an AGI measure could be moved into the $2^{\text {nd }}$ quintile under a broader measure such as FEI.

By inflating the income amounts for those families primarily included in the middle and upper income brackets, the FEI income concept biases tax policy deliberations. Using this methodology, virtually any broad-based income tax reduction proposal would appear to overly favor the so-called "wealthy" and understate the progressivity of any tax proposal. Thus, when distributional tax tables using the FEI concept purport to show that tax cuts are only going to the "rich," it only appears that way because the middle and upper income class categories have been inflated. In other words, because people are more familiar with AGI (and most have probably never even heard of FEI) a family with an AGI of $\$ 30,000$ that is evaluating the merits of a tax proposal based on the FEI concept would not necessarily recognize that the benefits accruing to a family making $\$ 50,000$ (based on the FEI concept) would actually apply to them. Hence, the family in this example would incorrectly identify themselves in the table. The use of the FEI income concept fails to give the American taxpayer a transparent, useful, meaningful, and understandable measure of income on which they can evaluate the merits of proposed tax legislation.

Under the FEI concept, "income is the money value of the net accretion to one's economic power between two points of time." 53 FEI is one measure of ability to pay. In other words, the FEI concept measures income as the amount a family can spend during a given time period and still have the same net assets at the end of the period as it did in the beginning. Since accrued, though unrealized, capital gains do, in theory, increase an individual's economic power to spend it is included in the Treasury's FEI measure of income. Like many other income sources

${ }^{51}$ Josiah Stamp, Some Economic Factors in Modern Life (London: King and Son., 1929), 258-259.

${ }^{52}$ Kennedy, A Guide to Econometrics ( $3^{\text {rd }}$ Edition) (Cambridge, MA: The MIT Press, 1992), 137.

${ }^{53}$ Robert Murray Haig, "The Concept of Income - Economic and Legal Aspects," in The Federal Income Tax, ed. Robert Murray Haig (Columbia University Press, 1921), 7. 
included in the Treasury FEI measure (e.g., inside buildup on life insurance and income earned in pension funds), many American taxpayers would argue that their pension funds are used for saving and do not provide current cash flow (another measure of ability to pay) that can be spent in the time period under analysis. Therefore, most of the items in the FEI concept should not be considered a source of income until the gains from such sources are realized and available for spending.

Although some economists in the Treasury Department and advocacy organizations may consider the Treasury's FEI measure to be a more theoretically correct measure of income, based on the statistical problems of imputation and inference discussed above, it is not as accurate or reliable as more narrow definitions of income such as AGI, which is available from singlesourced data files. Further, due to the many imputations that are inferred using an FEI income concept, an FEI income measure is likely less understandable to the public than an income measure based on AGI.

Although all of the items imputed in the FEI income concept are not equally misleading. The fallacy of including the imputed rental value of owner-occupied housing can be illustrated in the following example: The FEI concept attempts to impute the rental value of owned consumer durable goods, such as the imputed rental value from owner-occupied housing. In theory, economists will recognize that the imputed rental value of owner-occupied housing fits the FEI concept of income (i.e., the Haig-Simons theory of income discussed earlier). Furthermore, the average person understands that people who own their own homes are potentially wealthier than those that rent, due to the potential built up equity in owner-occupied housing. However, if owner-occupied housing is included as a durable good, why is not an owned car? Obviously, a person who owns a car is potentially wealthier than a person who cannot afford to own a car.

Therefore, under the FEI concept, there should also be an imputation for the rental value of owned automobiles. In fact, any consumer durable good that could be rented, as opposed to purchased, should have some rental value and, hence, should be included as imputed income. As Congressional Research Service economist Jane G. Gravelle states, "Imputed income, in economic theory, would include income from the flow from all durable goods..."54 This would then include cars, washing machines, dryers, refrigerators, televisions, etc.

Although the cost of depreciation and maintenance on most consumer durable goods would most likely net against any imputed rental value, the very notion that any imputed rental value for owned consumer durable goods (such as housing) should be included as "income" in distributional tax analysis is likely misleading and confusing to taxpayers. In fact, the largest item of imputed income in the National Income and Product Accounts compiled by the U.S. Department of Commerce (one of the data sources used by the Treasury Department) was \$159.8 billion in 1995 under the category personal interest income, which includes the benefits of banking services provided free to customers in lieu of interest. ${ }^{55}$

\footnotetext{
54 Jane G. Gravelle, “Imputed Income,” in The Encyclopedia of Taxation and Tax Policy, eds. Joseph J. Cordes, Robert D. Ebel, and Jane G. Gravelle (The Urban Institute Press, 1995), 168.

${ }^{55}$ Ibid.
} 
Additions to income as listed above push the average American family up to a higher income level relative to an AGI measure. The inclusion of additional income items, including the statistically questionable imputations relating to non-filer income, rental income from owneroccupied housing, inside buildup of life insurance, and unreported income, differs radically from the concept of AGI used by taxpayers on their tax returns and only serves to muddle the tax policy debate whenever significant tax legislation is discussed. People most likely will naturally view the results of a tax distribution table in the context most familiar to them -- AGI. When taxpayers see popular media reports that rely on FEI data, few are aware that the income definition used is based on a concept other than AGI, and one that few outside a handful of Washington tax experts can understand.

Besides possibly confusing the average citizen, the FEI concept biases the policy debate by moving families up the income ladder and making it appear that reductions in tax liabilities that would actually be received by the middle income families are primarily benefiting the wealthy. It's easier for a family of four making $\$ 30,000$ a year to discount the value of a tax reduction when tables based on FEI show that families with incomes above $\$ 50,000$ get most of the benefit. However, that family making $\$ 30,000$ a year does not understand that under the FEI concept, they are the family making $\$ 50,000$ a year.

As an illustration, a comparison of AGI to FEI using 1983 data showed that the value of total AGI in the economy was 67 percent of the value of total FEI. In other words, FEI was 50 percent greater than AGI. ${ }^{56}$ The Treasury Department verifies these figures in its own comparative analysis of AGI to FEI in a 1999 paper. ${ }^{57}$ Although analyzing the FEI impact on a specific income level is difficult because FEI departs so radically from the more commonly understood income definition of AGI, a study by the Congressional Joint Economic Committee compared AGI and FEI income levels by quintiles and discovered that Treasury's FEI income concept overstated income (based on AGI) by between 68 and 95 percent. ${ }^{58}$ Income levels at the $20^{\text {th }}, 40^{\text {th }}, 60^{\text {th }}$, and $80^{\text {th }}$ percentiles can be estimated using Internal Revenue Service tax return data and compared with the corresponding points in the FEI data using the quintile boundaries disclosed by the Treasury Department. As can be seen below in Table 4-3, the overstatement of income under FEI ranges from 68 to 95 percent. $^{59}$

\begin{tabular}{|l|r|c|r|}
\hline \multicolumn{4}{|c|}{ Table 4-3. Treasury Overstatement of Income } \\
\hline Quintile & Tax Return Data (AGI) & FEI & $\%$ Overstatement \\
\hline 20th Percentile & $\$ 8,701$ & $\$ 16,950$ & 94.80 \\
\hline 40th Percentile & $\$ 18,363$ & $\$ 32,563$ & 77.33 \\
\hline 60th Percentile & $\$ 31,866$ & $\$ 54,758$ & 71.84 \\
\hline 80th Percentile & \$55,540 & $\$ 93,222$ & 67.85 \\
\hline Source: U.S. Department of Treasury and Joint Economic Committee Calculations \\
\hline
\end{tabular}

\footnotetext{
${ }^{56}$ Susan C. Nelson, "Family Economic Income and Other Income Concepts Used in Analyzing Tax Reform,” Compendium of Tax Research, 1986, (Washington, DC: Office of Tax Analysis, Department of Treasury, 1987). (Emphasis added).

${ }^{57}$ Julie-Anne Cronin, “U.S. Treasury Distributional Analysis Methodology,” Department of the Treasury, Office of Tax Analysis, OTA Paper 85 (September 1999).

${ }^{58}$ Christopher Frenze, “Treasury Department’s Estimate of Tax Changes: A Review and Analysis,” Joint Economic Committee (July 1997).

${ }^{59}$ Ibid.
} 
The true effect of including all aspects of theoretical income under the FEI income measure is that it vastly overstates a more realistic measure of family income that is used in the preparation of tax returns and presumably more familiar to taxpayers -- AGI. Furthermore, most taxpayers will no doubt agree that the imputed rental value of any durable good should be excluded from income and "ability to pay" measures, and should purposefully be excluded from any income measure when evaluating changes in tax burdens resulting from changes in tax policies. One typical reaction to the Treasury approach is reflected in the following quotation from former ABC commentator and talk show host David Brinkley:

Finally, a few words about federal taxes and what some of the great minds in the U.S. Treasury are thinking about.

The Treasury likes to calculate the American people's ability to pay taxes based not on how much money we have, but on how much we might have or could have had. For example, a family that owns a house and lives in it, the Treasury figures that if the family didn't own the house and rented it from somebody else, the rent would be $\$ 500$ a month. So it would add that amount, $\$ 6,000$ a year, to the family's so-called imputed income. Imputed income is income you might have had, but don't. They don't tax you on that amount.

The IRS does not play this silly game. Instead the Treasury calculates how much they could take away from us if they decided to. If that were the system, consider the possibilities. How about being taxed on Ed McMahon's \$10 million magazine lottery? You didn’t win it, you say? But you could have. The Treasury must have something better to do. If not, there is a good place for Clinton to cut some spending. ${ }^{60}$

Furthermore, even Henry Simons (again, of the aforementioned Haig-Simons income concept) recognizes the major problem with imputing the rental value of owner-occupied housing. As he states:

Another difficulty with the income concept has to do with the whole problem of valuation. The precise objective measurement of income implies the existence of perfect markets from which one, after ascertaining quantities, may obtain the prices necessary for routine valuation of all possible inventories of commodities, services, and property rights. In actuality there are few approximately perfect markets and few collections of goods or properties which can be valued accurately by recourse to market prices. Thus, every calculation of income depends upon 'constructive valuation' i.e., upon highly conjectural estimates made, at best, by persons of wide information and sound judgment. ${ }^{61}$

\footnotetext{
60 “This Week with David Brinkley,” Washington, D.C.: ABC News, February 28, 1993, in Michael J. Graetz, "Distributional Tables, Tax Legislation, and the Illusion of Precision," 43, in Distributional Analysis of Tax Policy, ed. David F. Bradford (Washington, DC: AEI Press, 1995).

${ }^{61}$ Henry C. Simons, Personal Income Taxation: The Definition of Income as a Problem of Fiscal Policy, (Chicago: University of Chicago Press, 1938), 56. (Emphasis added).
} 
Hence, the FEI concept contains "highly conjectural"62 estimates that may be statistically unreliable and inaccurate. Data for which statistical measures of reliability and accuracy cannot be measured should not be used in analyses that are released into the public domain to influence tax policy.

Another major problem with the FEI measure results from the fact that the data include nonfilers with no income or payroll tax liability. In addition, there are millions of households that do not pay taxes and also rely on federal and state public assistance. ${ }^{63}$ It might be questionable whether it is appropriate to include those without tax liability in an analysis of income tax burdens.

Since most of these non-filers without tax liability will reside in the bottom quintiles, the mathematically predictable outcome is that any income tax reduction will not appear to provide significant benefits to low income households and the progressive nature of the tax system will be understated. Thus, any method that includes non-filers does not really analyze the effects of tax changes on taxpayers, but on taxpayers and non-taxpayers alike.

In addition, despite the term "Family" in the Family Economic Income concept, many of these non-filers actually are non-family households, i.e., single persons. ${ }^{64}$ Thus, for example, it would not be surprising that an income tax cut which includes a child tax credit provision would provide much larger average benefits to taxpaying families than to those who are non-filers without children and who disproportionately reside in the bottom quintile. The larger relative presence of non-filers and single persons in the bottom quintile means that the average benefits of income tax reductions in a distribution table will appear to be lower than they otherwise would be to those residing in the lower income categories.

In response to some of the criticisms of the Treasury's FEI concept raised by the Joint Economic Committee and elsewhere, ${ }^{65}$ the Treasury released companion distribution tables using another measure of income, "Cash Income." However, Treasury's notion of "cash income" still differs from the commonly understood concept of AGI. According to the Treasury Department, "Cash Income consists of wages and salaries, net income from a business or farm, taxable and taxexempt interest, dividends, rental income, realized capital gains, cash transfers from the government, and retirement benefits. Employer contributions for payroll taxes and the federal corporate income tax is added to place cash income on a pre-tax basis., ${ }^{.66}$

\footnotetext{
${ }^{62}$ Merriam Webster's Collegiate Dictionary, $10^{\text {th }}$ Edition (1993), defines conjecture as “inference from defective or presumptive evidence."

${ }^{63}$ For tax year 2001, 35.6 million tax returns (27.3\%) reported negative or zero federal income tax liability. See, Table 4-5 below.

${ }^{64}$ According to the Statistics of Income, Internal Revenue Service, 57.2 million returns (44\%) filed as single persons out of a total 130.1 million tax returns in 2002. Internal Revenue Service, Statistics of Income Division, SOI Bulletin, Fall 2004 (Washington, DC, 2004), 253.

${ }^{65}$ See, for example, Christopher Frenze, "Treasury Department's Estimates of Tax Changes: A Review and Analysis,” Joint Economic Committee (July 1997). See also, Bruce Bartlett, “Income Distribution,” Brief Analysis \#303 (Washington, DC, National Center for Policy Analysis, August 10, 1999).

${ }_{66}^{6}$ Julie-Anne Cronin, “U.S. Treasury Distributional Analysis Methodology,” Department of the Treasury, Office of Tax Analysis, OTA Paper 85 (September 1999), 18.
} 
Furthermore, the addition of many millions of non-taxpayers at the bottom of the income range ratchets up the relative position of taxpayers in the income distribution. For example, millions of taxpayers that were in the fourth quintile are pushed up into the top fifth of households. In other words, the Treasury approach increases taxpayer income in both relative and dollar terms. This is further evidence of how the Treasury's FEI and "cash income" concepts bias the consideration of tax policy changes and underestimate the progressivity of the tax system. ${ }^{67}$

Though the Office of Tax Analysis has shelved the FEI concept under the Bush Administration, it is important that readers of this dissertation research have an understanding of how different income measures can be used to alter the perspectives of fairness. Under a different administration, FEI may once again become the standard income definition for distribution analysis at the Treasury Department. Further, advocacy groups and think-tanks may decide to use an income measure similar to the FEI for future tax distribution analyses.

\section{Misuse OF AVERAGES}

Michael Graetz, former Deputy Assistant Secretary of the Treasury for Tax Policy under President George H.W. Bush, argues "The current practice of fashioning tax legislation to achieve a particular result in a distribution table creates the illusion of precision when such precision is impossible." ${ }^{, 68}$ It is statistically possible, even probable, based on averages, that some taxpayers in a given income class would receive no tax cut or even face a tax increase regardless of the average tax change for their income group. Furthermore, not only is precision impossible but the use of averages misrepresents the central tendency of the data.

However, it is often necessary to describe data using a single number. The central tendency of the distribution of data is a point estimate or single number that corresponds to a typical, representative or middle score for a given set of data. Examples of such measures are the mean, the median and the mode.

The mean, commonly referred to as the average, is the most recognized and easily understood measure of central tendency. To calculate the average, the value for each observation in the data is added together and then the sum is divided by the total number of observations. Some common uses of averages are batting averages in baseball and student grade point averages. The use of averages is simple and easy for people to understand. However, the use of averages may not be appropriate if the data exhibit large variability, there are many outliers in the data or the data do not fit the pattern of a normal distribution. This is because the average as a measure of central tendency can be highly influenced by extreme values. For example, if all humans were either 10 feet tall or two feet tall and divided equally between the two, it would not be helpful to describe humans, on average, as six feet tall and build all homes and cars as if all humans were six feet tall.

\footnotetext{
${ }^{67}$ See, for example, Christopher Frenze, "Treasury Department's Estimates of Tax Changes: A Review and Analysis,” Joint Economic Committee (July 1997). See also, Bruce Bartlett, "Income Distribution,” Brief Analysis \#303 (Washington, DC, National Center for Policy Analysis, August 10, 1999).

${ }^{68}$ Michael J. Graetz, "Distributional Tables, Tax Legislation, and the Illusion of Precision," in Distributional Analysis of Tax Policy, ed. David F. Bradford (Washington, DC: AEI Press, 1995), 18.
} 
In the context of tax distribution analysis the average is actually the least representative measure. Chart 4-1 details the dispersion of 2001 federal income tax returns around the average federal income tax liability. ${ }^{69}$ The unit of analysis is federal income tax returns for 2001, grouped into quintiles by adjusted gross income (AGI). ${ }^{70}$ The data are further grouped into three categories: More than '25\% Above the Average'; Within +/- 25\% of the Average; and Below '25\% Less than the Average'. 71

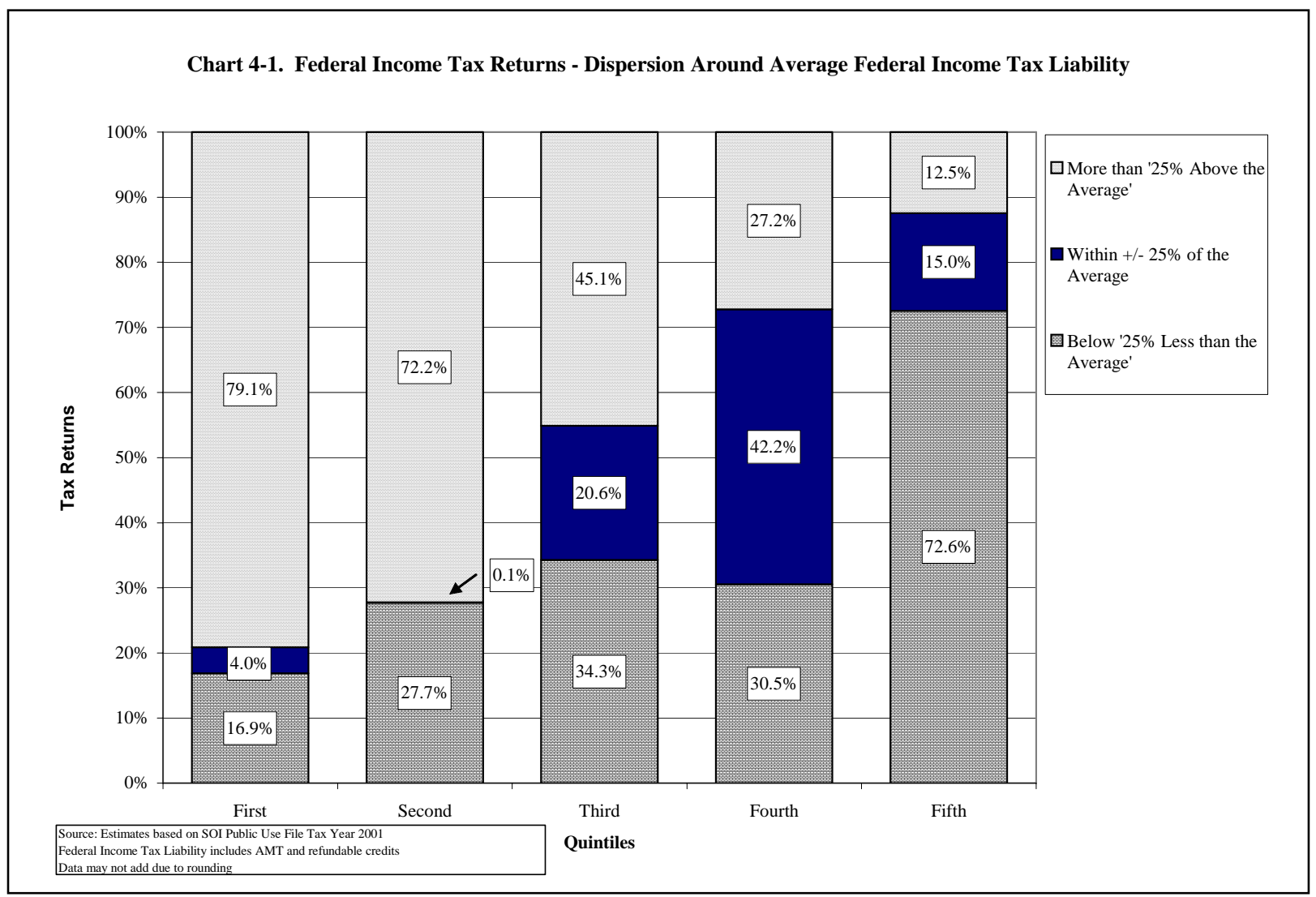

The average federal income tax liability for the first quintile (the lowest ranked by AGI) is $-\$ 270$ (see Table 4-4 below). The amount of tax liability is negative because so many taxpayers in the first quintile have either zero tax liability or receive a net transfer from the government due to the refundable portion of the Earned Income Tax Credit (EITC) and Child Tax Credit (CTC).

\footnotetext{
${ }^{69}$ The results of the analysis are similar under different tax years. For an example using 1999 tax data, see: Jason Fichtner, "The Misleading Effects of Averages in Tax Distribution Analysis," U.S. Congress, Joint Economic Committee (September 2003).

${ }^{70}$ The data used in this study are from the Internal Revenue Service - Statistics of Income Division Public Use File for tax year 2001, the most recently available public use file at the time this research was performed. For a full description of the IRS Public Use File, including sampling error and disclosure avoidance procedures, see: Mike Weber. United States Internal Revenue Service, Statistics of Income Division. "General Description Booklet for the 2001 Public Use Tax File.”

${ }^{71}$ For example, if the average were $\$ 100$ then "More than '25\% Above the Average”" would include returns with tax liability greater than $\$ 125$; "Within +/- 25\% of the Average" would include $\$ 75$ - $\$ 125$; and "Below '25\% Less than the Average”" would include returns with tax liability below $\$ 75$.
} 
Hence, many of the returns in the first quintile do not actually pay federal income taxes and, due to the refundable portion of the EITC and CTC, many do not effectively pay payroll taxes.

Additionally, referencing Chart 4-1, in the first quintile only 4.0 percent of all returns reported federal income tax liability within plus or minus 25 percent of the average. The most representative grouping in the first quintile is "More than '25\% Above the Average.'” At first glance, it might be surprising that 79.1 percent of returns in the first quintile report a tax liability that is greater than the average. However, as stated earlier, the average as a measure of central tendency can be highly influenced by extreme values. Extreme values can be either positive or negative. For tax year 2001, the maximum refundable credit (or maximum transfer from the government) was $\$ 4,008$ or a federal income tax liability of $-\$ 4,008 .^{72}$

\begin{tabular}{|c|c|c|c|c|}
\hline & Average & $\begin{array}{l}\text { Below '25\% Less } \\
\text { than the Average' }\end{array}$ & $\begin{array}{c}\text { Greater than '25\% } \\
\text { Less than the } \\
\text { Average' }\end{array}$ & $\begin{array}{c}\text { Maximum Transfer } \\
\text { Payment }\end{array}$ \\
\hline All Returns & $\$ 6,570$ & $\$ 4,930$ & $\$ 8,210$ & $-\$ 4,010$ \\
\hline Quintile 1 & $-\$ 270$ & $-\$ 200$ & $-\$ 340$ & $-\$ 4,010$ \\
\hline Quintile 2 & $-\$ 140$ & $-\$ 100$ & $-\$ 170$ & $-\$ 4,010$ \\
\hline Quintile 3 & $\$ 1,810$ & $\$ 1,360$ & $\$ 2,260$ & $-\$ 2,330$ \\
\hline Quintile 4 & $\$ 4,780$ & $\$ 3,580$ & $\$ 5,970$ & $\$ 0$ \\
\hline Quintile 5 & $\$ 26,680$ & $\$ 20,010$ & $\$ 33,350$ & $\$ 0$ \\
\hline \multicolumn{5}{|c|}{$\begin{array}{l}\text { Notes: Data rounded to tens } \\
\text { Negative Amounts in Bold } \\
\text { Federal Income Tax Liability includes AMT and refundable credits } \\
\text { Maximum refundable credit in } 2001 \text { was } \$ 4,008 \\
\text { Source: Estimates based on SOI Public Use File Tax Year } 2001\end{array}$} \\
\hline
\end{tabular}

As shown in Table 4-5, approximately 19.7 million returns in the first quintile reported zero or negative tax liability. Positive tax liability was reported by 6.4 million returns. The 19.7 million returns with zero or negative income tax liability includes 6.5 million returns with negative income tax liability, of which 3.4 million tax returns in the first quintile received a net transfer of more than $\$ 1,000$ from the government in 2001. Though 79.1 percent of returns in the first quintile have tax liabilities more than 25 percent above the average, the 3.4 million tax returns with negative tax liability over $\$ 1,000$ skews the average. Hence, the average is an inappropriate measure of central tendency in the first quintile.

\footnotetext{
${ }^{72}$ Author estimates based on SOI Public Use File Tax Year 2001.
} 


\begin{tabular}{|c|c|c|c|c|c|c|c|c|c|c|}
\hline & \multicolumn{2}{|c|}{$\begin{array}{c}\text { Returns with Negative or } \\
\text { Zero Tax Liability }\end{array}$} & \multicolumn{2}{|c|}{$\begin{array}{c}\text { Returns with Negative } \\
\text { Tax Liability }\end{array}$} & \multicolumn{2}{|c|}{$\begin{array}{c}\text { Returns Receiving Less } \\
\text { than } \$ 500 \text { in Refundable } \\
\text { Credits }\end{array}$} & \multicolumn{2}{|c|}{$\begin{array}{c}\text { Returns Receiving } \$ 500 \text { to } \\
\$ 999 \text { in Refundable } \\
\text { Credits }\end{array}$} & \multicolumn{2}{|c|}{$\begin{array}{c}\text { Returns Receiving } \$ 1,000 \\
\text { or More in Refundable } \\
\text { Credits }\end{array}$} \\
\hline & Returns & $\begin{array}{c}\text { \% of } \\
\text { Returns In } \\
\text { Category }\end{array}$ & Returns & $\begin{array}{c}\text { \% of } \\
\text { Returns In } \\
\text { Category }\end{array}$ & Returns & $\begin{array}{c}\text { \% of } \\
\text { Returns In } \\
\text { Category }\end{array}$ & Returns & \begin{tabular}{c|}
$\%$ of \\
Returns In \\
Category
\end{tabular} & Returns & $\begin{array}{c}\text { \% of } \\
\text { Returns In } \\
\text { Category }\end{array}$ \\
\hline All Returns & $35,573,700$ & $27.3 \%$ & $16,735,100$ & $12.8 \%$ & $3,597,400$ & $2.8 \%$ & $1,688,000$ & $1.3 \%$ & $11,449,700$ & $8.8 \%$ \\
\hline Quintile 1 & $19,666,800$ & $75.5 \%$ & $6,477,600$ & $24.9 \%$ & $2,538,700$ & $9.7 \%$ & 505,100 & $1.9 \%$ & $3,433,800$ & $13.2 \%$ \\
\hline Quintile 2 & $10,656,500$ & $40.9 \%$ & $7,326,600$ & $28.1 \%$ & 241,700 & $0.9 \%$ & 476,600 & $1.8 \%$ & $6,608,300$ & $25.4 \%$ \\
\hline Quintile 3 & $4,567,200$ & $17.5 \%$ & $2,930,900$ & $11.3 \%$ & 816,900 & $3.1 \%$ & 706,400 & $2.7 \%$ & $1,407,600$ & $5.4 \%$ \\
\hline Quintile 4 & 604,600 & $2.3 \%$ & - & $0.0 \%$ & - & $0.0 \%$ & - & $0.0 \%$ & - & $0.0 \%$ \\
\hline Quintile 5 & 78,500 & \begin{tabular}{l|l|}
$0.3 \%$ \\
\end{tabular} & - & $0.0 \%$ & - & $0.0 \%$ & - & $0.0 \%$ & - & $0.0 \%$ \\
\hline $\begin{array}{l}\text { Notes: Data ma } \\
\text { Federal Income } \\
\text { Total Number } \\
\text { Source: Joint } 1\end{array}$ & $\begin{array}{l}\text { add due to ro } \\
\text { Liability Incl } \\
\text { urns }=130,25\end{array}$ & $\begin{array}{l}\text { ng (rounded to } \\
\text { AMT and Refu } \\
0 \text { with approxi }\end{array}$ & $\begin{array}{l}\text { undreds), weig } \\
\text { dable Credits } \\
\text { ately } 26.05 \mathrm{mi}\end{array}$ & $\begin{array}{l}\text { g and disclosu } \\
\text { n returns per qu }\end{array}$ & $\begin{array}{l}\text { requiremen } \\
\text { tile }\end{array}$ & & & & & \\
\hline
\end{tabular}

Similar to the first quintile, the average tax liability for the second quintile is also negative (-\$140) and the most representative grouping is returns with tax liability more than 25 percent above the average. The average is even less representative in the second quintile and, therefore, a more inappropriate measure of central tendency, with only 0.1 percent of tax returns reporting tax liability within plus or minus 25 percent of the average. Such a small representation is partly due to the small magnitude of the average tax liability for the second quintile and the fact that returns with zero or very little positive tax liability will be just above the average. The average for the second quintile is $-\$ 138$. This equates to a range of plus or minus 25 percent around the average of $-\$ 173$ to $-\$ 104$. Under such a tight range, only 20,800 returns fall into this category, 0.1 percent of the approximately 26.05 million tax returns in the second quintile.

Though the most representative grouping in the third quintile is still "More than '25\% Above the Average,"” the dominance declines. Only 45.1 percent of returns fall into this category and those returns falling within plus or minus 25 percent of the average increases to 20.6 percent. The fourth quintile exhibits the most normal statistical distribution, with 42.5 percent of returns reporting tax liability within plus or minus 25 percent of the average.

However, the distribution around the average becomes skewed once again in the fifth quintile. The existence of extreme outliers in the fifth quintile raises the average tax liability to \$26.600. The top 1 percent of returns alone reported an average tax liability over $\$ 233,600 .^{73}$ However, not surprisingly, many taxpayers in this quintile pay less than 25 percent below the average. In the fifth quintile, 72.6 percent fall into this category. Therefore, the average is an inappropriate measure of central tendency in the fifth quintile as well.

As shown in Table 4-5, for tax year 2001, 27.3 percent of all tax returns reported zero or negative federal income tax liability. This amounts to 35.6 million tax returns. It is interesting to note that many returns up through the third quintile received net transfers from the government (i.e., reported a negative income tax liability). It is also interesting to note that there are actually taxpayers in each quintile who reported zero tax liability on their federal tax returns in 2001.

\footnotetext{
${ }^{73}$ Dave Campbell and Michael Parisi, “Individual Income Tax Rates and Shares, 2001,” Internal Revenue Service, Statistics of Income Division, SOI Bulletin, Spring 2004 (Washington, DC, 2004), 37-38. (Total income tax reported for top $1 \%$ equals $\$ 300.9$ billion divided by 1.29 million returns in the top 1 percent.)
} 
The existence of 35.6 million returns, or one-quarter of all federal income tax returns, which have zero or negative income tax skews the average and makes the use of the average misleading. Further, since tax distribution tables predominantly focus on the "average tax cut" that each income group would expect to receive, the debate over the benefits of a tax cut is clouded when one-quarter of tax returns cannot receive a federal income tax cut because they do not pay federal income taxes and many effectively do not pay payroll taxes.

Using the same data that appears in Chart 4-1, Chart 4-2 presents a pie chart for the third, or middle, quintile. As Chart 4-3 further demonstrates, when these categories are analyzed the category of "Within +/- 25\% of the Average" is the least representative category.

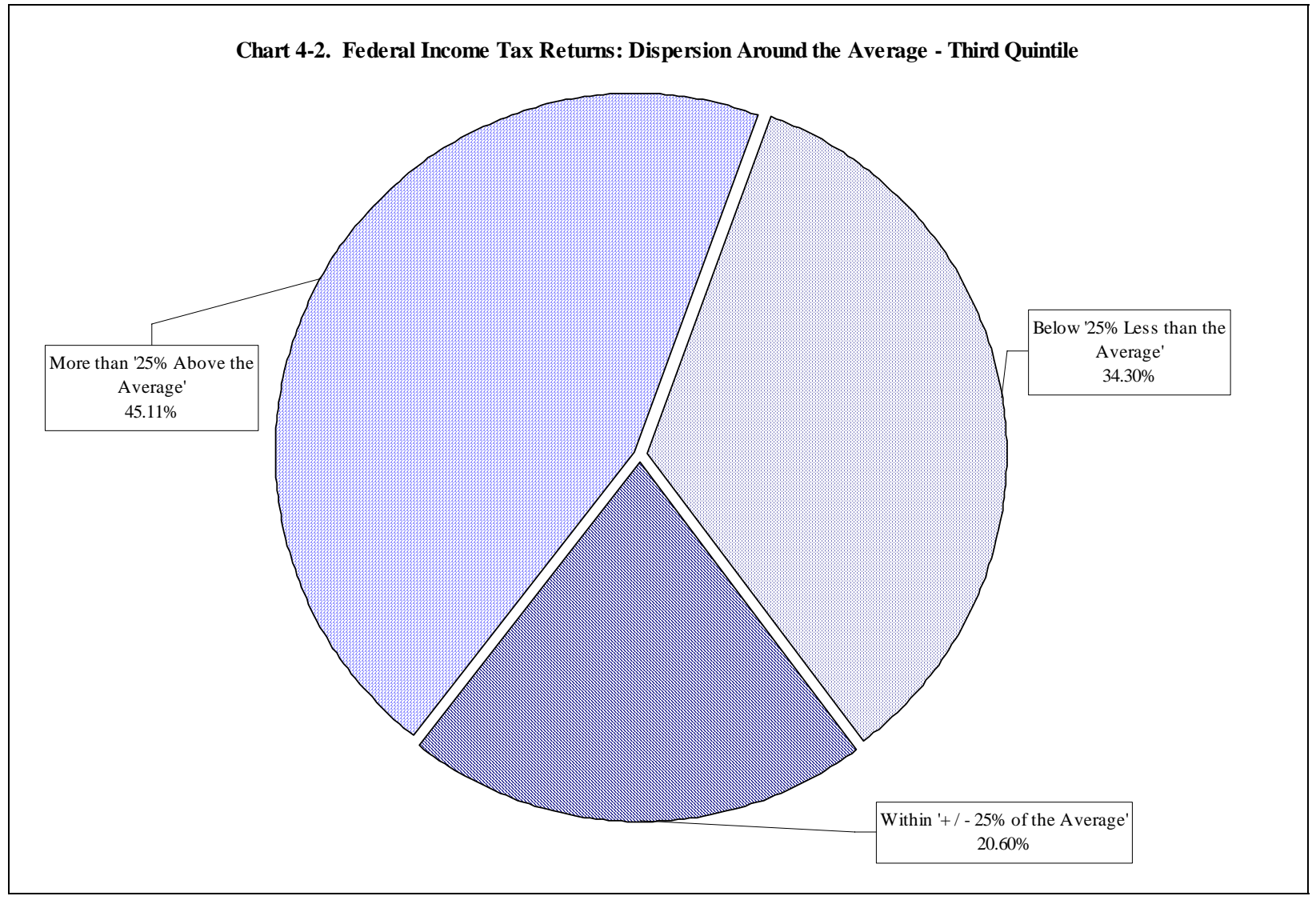

Unfortunately, many disseminators of tax distribution tables continue to use averages in their distribution tables despite the inherent problems with the use of averages. For example, focusing on a claim that an administration tax proposal would result in a average tax cut of $\$ 1,083$, authors in a Tax Notes article illustrated how the use of averages can be misleading by pointing out that "under the administration's proposal, 78.4 percent of income tax filers and 71.1 percent of income tax payers would receive less than $\$ 1,000 ., 74$

\footnotetext{
${ }^{74}$ William Gale and Peter Orszag, “The President’s Tax Proposal: Second Thoughts,” Tax Notes, January 27, 2003, 607.
} 
Shortly thereafter, these authors released a tax distribution table in the same publication using the average as the sole measure of central tendency to characterize taxpayers and purport to show the average tax cut resulting from the benefits of the Economic Growth and Tax Relief Reconciliation Act of 2001. ${ }^{75}$ Presumably, the same authors that criticized the use of an average tax cut amount as misleading in one article would similarly be aware that they were misleading in their subsequent article by focusing on average tax cut amounts. Unfortunately, many groups consistently misuse the average in reporting the results of their distributional analyses. ${ }^{76}$

Tax distribution tables ultimately focus on how much more or less in taxes income groups will pay under a change in tax law. As Graetz has also stated, "All that a distributional table can show is the total impact on all the families or couples within the same income classification. This rather obvious and important point often seems to be lost to policy makers."77 In other words, the use of averages alone is inappropriate because averages cannot accurately show the impact on most taxpayers within the same income classification. Hence, because the majority of distribution tables that are released focus on the average as a measure of central tendency, they give the false impression that the average properly typifies each taxpayer.

As the tables and graphs in this chapter have demonstrated, using the average as the measure of central tendency when analyzing or discussing tax policy initiatives is quite misleading, but this is the basis for computing projected tax changes in distribution tables. The use of averages when displaying distribution data for income and tax liability can mislead the public and cloud the transparency necessary for the public to effectively evaluate the merits of any proposed tax plan. But the use of averages is only part of the story. Not only is the use of averages as a measure of central tendency misleading, but also so is the use of quintiles or income categories based on AGI or any other measure of income. These arbitrary categories imply that the taxpayers grouped into these categories are similar in economic status and pay similar taxes. This assumption is far from the case.

\section{MisClASSIFICATION OF TAXPAYERS}

It is well known to most taxpayers that tax liabilities often differ among families with the same income. This can be because of family size, filing status, whether a family itemizes their deductions or elects to take the standard deduction, whether a family pays a mortgage on their home and deducts the interest expense or rents, the nature of a family's income, and many other factors. Additionally, some families are more aggressive in reducing their tax liabilities than others. For example, this can be done legally by contributing to a 401(k) plan, an individual retirement account or a medical savings account, and in many other ways as well.

\footnotetext{
${ }^{75}$ William Gale, Matthew Hall, and Peter Orszag, “Future Income Tax Cuts From the 2001 Tax Legislation,” Tax Notes, February 17, 2003.

76 See, for example: Andrew Lee and Joel Friedman, “Administration Continues to Rely on Misleading Use of 'Averages’ to Describe Tax-Cut Benefits,” Center on Budget and Policy Priorities, May 28, 2003; Bob McIntrye, “Final Tax Plan Tilts Even More Toward Richest,” Citizens for Tax Justice, May 22, 2003; and Urban-Brookings Tax Policy Center, "Table 5.1 - Conference Agreement on the Jobs and Growth Tax Relief Reconciliation Act of 2003: Distribution of Income Tax Change by AGI Class, 2003,” May 22, 2003.

77 Michael J. Graetz, "Distributional Tables, Tax Legislation, and the Illusion of Precision," in Distributional Analysis of Tax Policy, ed. David F. Bradford (Washington, DC: AEI Press, 1995), 45.
} 
The use of averages is further misleading by the grouping of taxpayers by income measures into quintiles which could suggest that there exists horizontal equity, or close similarities, among these taxpayers with respect to the amount of federal tax liability. The suggested correlation that higher income taxpayers always have higher tax liabilities is not necessarily the case. Further, the suggested notion that horizontal equity, or equal treatment (equal tax liability for equal income) exists within income categories is misleading as well. As former Congressional Budget Office Director Rudolph G. Penner discusses, tax distribution tables "obscure very large differences in the tax treatment of individuals within any income group.",78

For example, while it seems counterintuitive that a taxpayer in a lower income category can pay more in taxes than a taxpayer in a higher category, this is possible because millions of taxpayers have more in common with each other based on tax liability than based on income, as illustrated in Charts 4-3, 4-4, and 4-5. This important fact is ignored in typical tax distribution tables. It could be suggested that incidents of taxpayers in a lower income quintile paying more in taxes than taxpayers in a higher quintile are outliers and should be discarded from the sample. Not only would discarding these observations fail to highlight these cases in our tax system, but it would also fail to enlighten the public that taxpayer misclassification is actually a problem involving millions of taxpayers, not just a few extreme cases.

The focus of Chart 4-3 is on all tax returns that paid at least $\$ 1,000$ in federal income tax in 2001, ranked by AGI and grouped into quintiles. As the chart shows, there are millions of taxpayers in the third quintile who pay more in taxes than millions of taxpayers in the fourth quintile. Similarly, there are millions of taxpayers in the fourth quintile who pay more in taxes than millions of taxpayers in the fifth quintile.

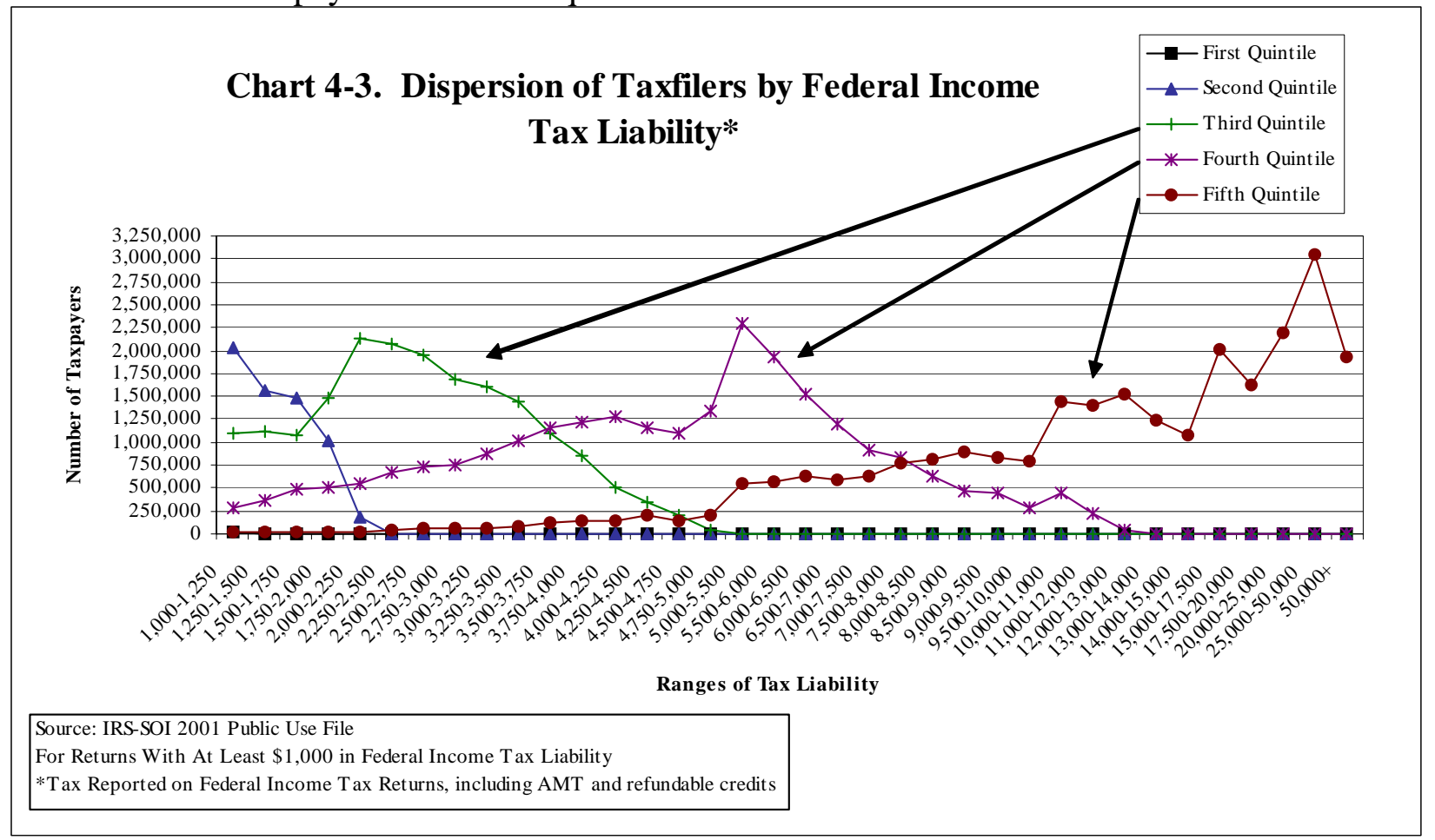

\footnotetext{
${ }^{78}$ Rudolph G. Penner, “Searching for a Just Tax System,” Discussion Paper No. 13, Urban-Brookings Tax Policy
} Center (January 2004). 


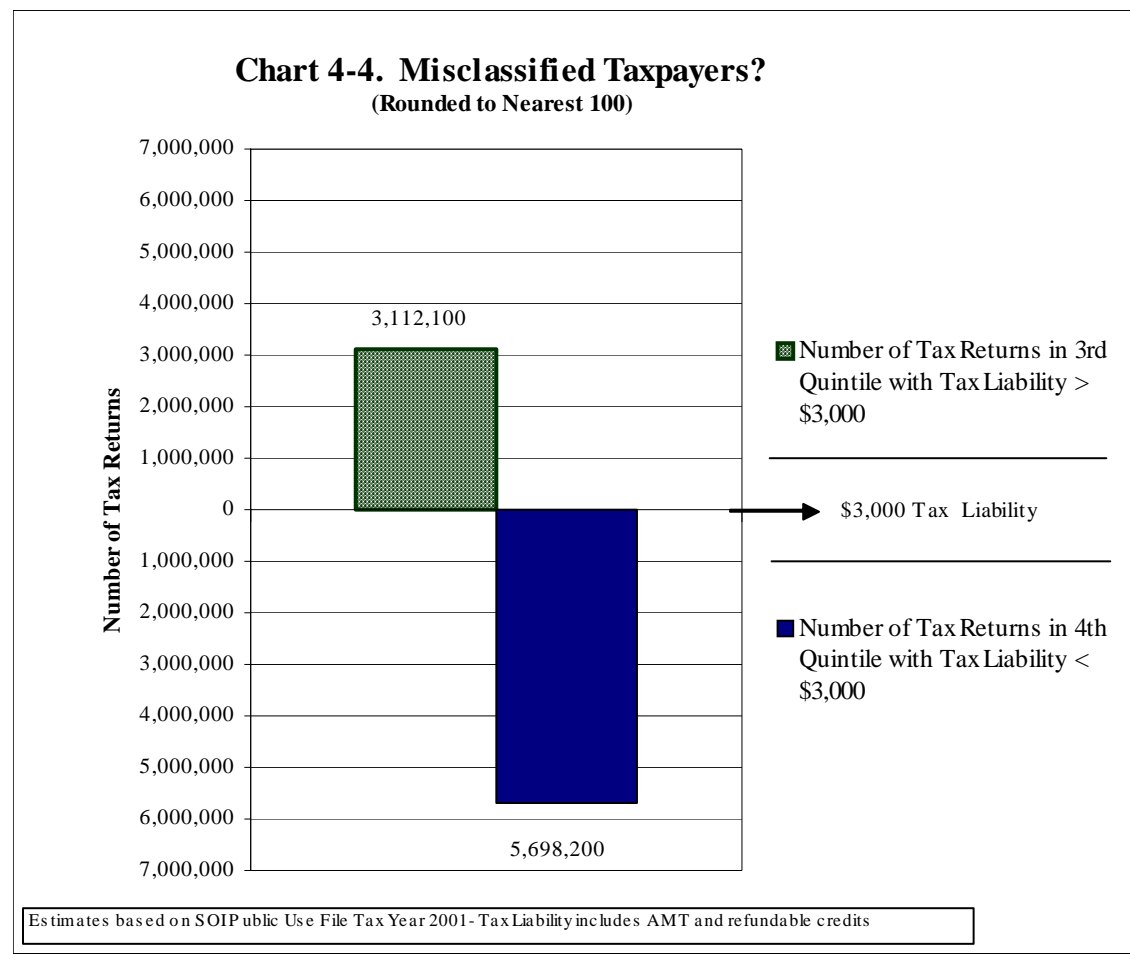

Based on Chart 4-3, Chart 4-4 shows that there are 3.1 million tax returns in the third quintile that paid $\$ 3,000$ or more in federal income taxes, compared with 5.7 million tax returns in the fourth quintile that paid less than $\$ 3,000$, even though these taxpayers are in a higher income quintile.

Chart 4-5 sheds light on a similar story between the fourth and fifth quintiles. Even though they are in a lower income quintile, 4.3 million tax returns in the fourth quintile paid more than $\$ 7,000$ in federal income tax in 2001, compared with almost 3.8 million tax returns in the fifth and "richest" quintile that paid less than $\$ 7,000$.

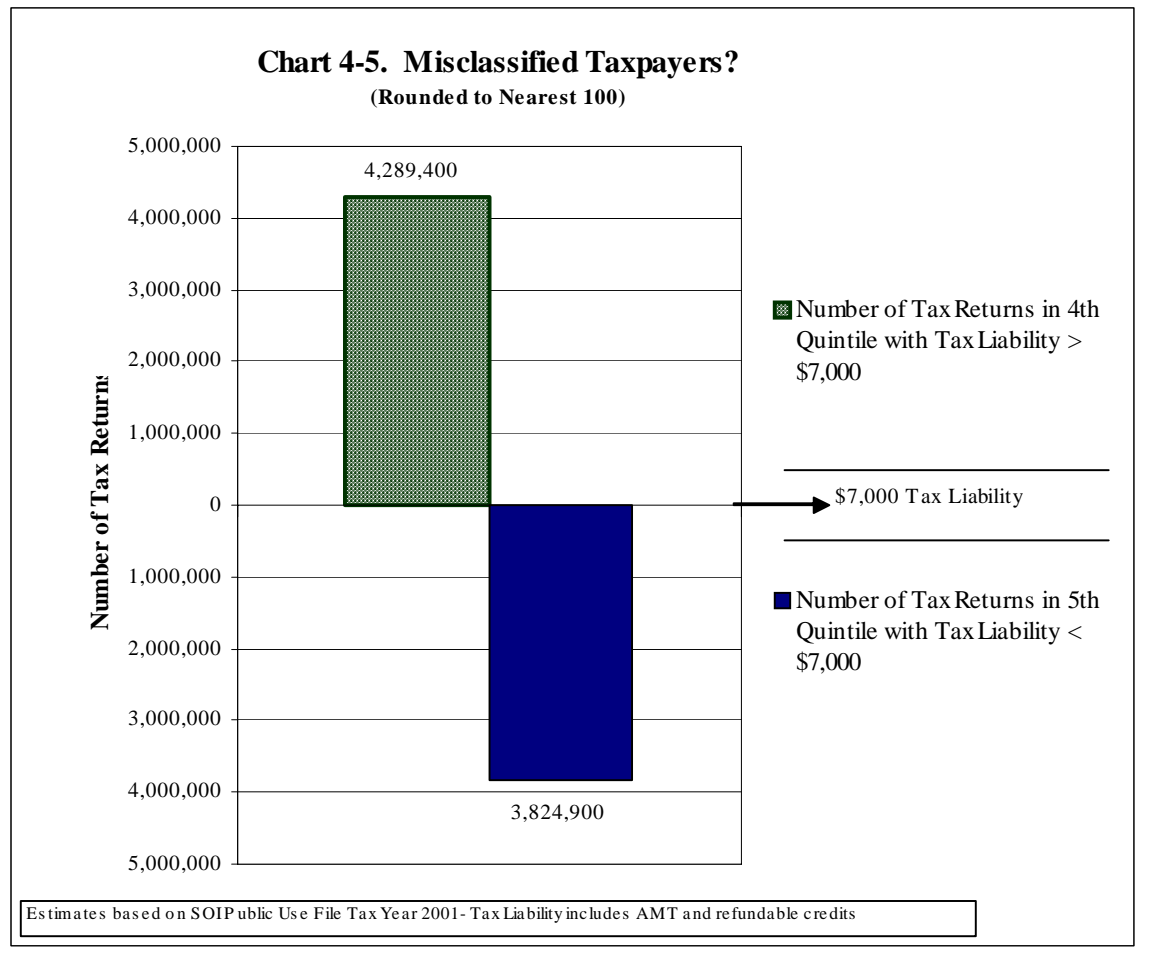

For tax year 2001, there were roughly 130.3 million federal tax returns. This amounts to about 26.05 million tax returns per quintile. Chart 4-4 suggests that based on a tax liability of $\$ 3,000$, over 5.7 million taxpayers in the fourth quintile (approximately 22 percent of returns in the fourth quintile) might have more in common with 23 million taxpayers in the third quintile than they do with the other members of the fourth quintile. Similarly, Chart 4-5 suggests that 3.8 million taxpayers in the fifth quintile (approximately 16 percent of returns in the fifth quintile) might have more in common with 22 million taxpayers in the fourth quintile than they do with the rest of the taxpayers in their own quintile. 
Ultimately, since tax distribution tables are concerned with the amount of tax before and after a proposed tax legislation is enacted, it is questionable whether policymakers and the public are best served by classifying taxpayers into rigid income categories. It is especially questionable when, based on income measures alone, millions of taxpayers have less in common with taxpayers of their own income quintile because the amount of tax they pay is more similar to taxpayers in other income quintiles.

However, this analysis is not suggesting that distribution tables should be categorized by tax liabilities. Doing so would pose problems as equally challenging as categorizing tax returns based on income measures. The use of rigid income categories along with the use of averages can suggest that there is similar ability to pay and similar tax liability within an income category. This is wrong.

The point is that focusing on income measures alone contributes to the illusion of precision, does not allow for a complete analysis of equity, and can influence perspectives. Without any understanding or discussion of wealth, debt or budget constraints, focusing on income as a measure of ability to pay can be misleading. The use of income categories without detailed descriptions of the limitations of the data misleads the public by suggesting that tax distribution tables are accurate, precise and completely reflect a correct picture of the American taxpaying population.

\section{INCOME MOBILITY}

The purpose of the section is not to point out a particular political bias in tax distribution tables, but to highlight another deficiency in the current practice of tax distribution analysis so that readers of this dissertation can have a complete understanding of the issue. Tax changes alter the after-tax prices and costs of goods and services, thereby adjusting the relative mix of inputs used in production, the types of goods and services businesses offer, as well as the amount of labor and capital. Tax changes can alter the economy and can produce broad economic effects that are not reflected in distributional analyses. One such factor is income mobility.

The results of any distributional tax table are based over some stated time horizon -- one year, five years, 10 years, or over a lifetime. Presenting estimates in this fashion implicitly assumes a static, non-mobile population of Americans. Tax distribution tables are usually used in a way that ignores the important factor of income mobility.

Studies by the Joint Economic Committee (JEC) support the conclusion that due to the great degree of income mobility in the U.S. economy, comparisons of similar income categories over time are virtually meaningless. ${ }^{79}$ According to these studies, 85.8 percent of filers in the bottom quintile in 1979 had exited this quintile by 1988. The corresponding rates were 71 percent for the second lowest quintile, 67 percent for the middle quintile, 62.5 percent for the fourth quintile,

\footnotetext{
${ }^{79}$ See, for example: Christopher Frenze, “Income Mobility and Economic Opportunity,” Joint Economic Committee (June 1992); and JEC staff study "Income Mobility and the U.S. Economy: Open Society or Caste System?” Joint Economic Committee (January 1992).
} 
and 35.3 percent for the top quintile. Taxpayers residing in the often-discussed top one percent had a mobility rate of 52.7 percent.

As Mark Maier points out in his influential book The Data Game: Controversies In Social Science Statistics, longitudinal data from the University of Michigan's Panel Study of Income Dynamics (PSID) and the Census Bureau's Survey of Income and Program Participation (SIPP) also show considerable movement between income classes. ${ }^{80}$ Using the official U.S. government poverty level as a benchmark, the PSID data found that only 2.6 percent of the population was poor in eight out of 10 years between 1969 and 1978, while over 24 percent were poor for at least one year. ${ }^{81}$ Similarly, the SIPP data found that only 6 percent of the population was poor in every month of 1984, but 26 percent were poor for at least one month. ${ }^{82}$

Because distribution tables are based on an annual period, they fail to account for income mobility, or the dynamic nature of society where people move in and out of income groups over the course of their lives. The significant degree of income mobility is evident in data released by the Council of Economic Advisers (CEA) and provides further evidence that tax distribution tables are misleading. The CEA table is reproduced as Table $4-6 .^{83}$

The tabulations indicate a substantial amount of mobility between income classes over a 10-year period. Taxpayers who remained subject to the same statutory tax rate in both the beginning year of the study (year 1) and the final year of analysis (year 10) are shown in bold along the diagonal. For example, between 1987 and through 1996, 66.2 percent of taxpayers exited the bottom tax bracket (33.8 percent remained; subtracted from 100 percent, this equals 66.2 percent that exited). Over the same period, 76.0 percent exited the 28 percent bracket, while 50.9 percent exited the top tax bracket.

According to the tabulations, 53 percent of taxpayers were in a different tax rate bracket at the end of the 10-year period. These data show that over half of all taxpayers studied during the 10year period eventually experienced changes in their lives that result in changes in their incomes and move them to a different income tax bracket. This movement can be either upwards or downwards. According to the CEA, "about 51 percent of the taxpayers in the top bracket in the first year were in a lower tax bracket after 10 years. Forty-seven percent of taxpayers in the top two brackets in year 1 had moved down to at least the 28 percent tax bracket by year 10.”84

The nature of tax distribution tables to show only a "snapshot" of taxpayers at one specific point in time fails to account for the dynamic nature of income mobility in society. The result is tax distribution tables that mislead the public by cementing taxpayers into particular income groups and failing to appropriately indicate "that tax burdens in a given year may tell a very different

\footnotetext{
${ }^{80}$ Mark H. Maier, The Data Game - Controversies in Social Science Statistics, (Armonk, NY: M.E. Sharpe, 1991).

${ }^{81}$ Ibid., 127.

${ }^{82}$ Ibid.

${ }^{83}$ Council of Economic Advisers, Executive Office of the President, The Annual Report of the Council of Economic Advisers, together with the Economic Report of the President, U.S. Government Printing Office (Washington, DC, February 2003), 199.

${ }^{84}$ Ibid.
} 
story of the distribution of the tax burden than do measures of tax burdens over longer horizons." 85

\begin{tabular}{|c|c|c|c|c|c|c|c|c|}
\hline \multicolumn{9}{|c|}{$\begin{array}{c}\text { Table 4-6. Taxpayers by EGTRRA Rate Bracket Using Panel } \\
\text { Of Taxpayers from } 1987 \text { through } 1996\end{array}$} \\
\hline \multirow{2}{*}{$\begin{array}{c}\text { Year } 1 \text { tax } \\
\text { bracket } \\
\text { (percent) }\end{array}$} & \multicolumn{7}{|c|}{ Year 10 tax bracket (percent) } & \multirow{2}{*}{$\begin{array}{c}\text { Returns in } \\
\text { year } 1 \\
\text { (thousands) }\end{array}$} \\
\hline & 0 & 10 & 15 & 25 & 28 & 33 & 35 & \\
\hline & \multicolumn{7}{|c|}{ Taxpayers by rate bracket (percent distribution) } & \\
\hline 0 & 33.8 & 24.7 & 32.1 & 7.7 & 0.8 & 0.5 & 0.3 & 10,360 \\
\hline 10 & 20.1 & 29.3 & 40.8 & 8.8 & 0.6 & 0.3 & 0.1 & 15,370 \\
\hline 15 & 8.6 & 13.3 & 53.4 & 22.9 & 1.2 & 0.4 & 0.2 & 50,059 \\
\hline 25 & 3.9 & 5.1 & 29.9 & 51.4 & 6.7 & 2.2 & 0.8 & 31,427 \\
\hline 28 & 3.3 & 2.8 & 11.6 & 35.9 & 24 & 14.7 & 7.5 & 2,682 \\
\hline 33 & 4.7 & 2.6 & 9.1 & 21 & 18.9 & 23.9 & 19.8 & 1,096 \\
\hline 35 & 5.1 & 1.9 & 5.7 & 10.4 & 8.8 & 19 & 49.1 & 633 \\
\hline \multicolumn{9}{|c|}{$\begin{array}{l}\text { Note.-Tabulations from 1987-1996 panel of taxpayers. Tabulations include only non-dependent taxpayers present in } \\
\text { all years of the panel data set. Each cell entry indicates the percent of taxpayers in a rate bracket in the last year of the } \\
\text { panel (i.e., column entry) relative to the number of all taxpayers in that rate bracket in the first year of the panel (i.e., } \\
\text { row sum). } \\
\text { Source: Council of Economic Advisers, based on tabulations provided by Department of the Treasury, Office of Tax } \\
\text { Analysis. }\end{array}$} \\
\hline
\end{tabular}

Chart 4-6 shows that the entire bottom half (bottom 50 percent) of taxpayers that reported positive AGI paid 3.5 percent of all individual taxes in 2002. This compares with 33.71 percent paid by the top 1 percent, 53.8 percent paid by the top 5 percent and 65.73 percent (well over half of all individual taxes) paid by the top 10 percent of taxpayers reporting positive AGI. Obviously, if the bottom half of all taxpayers, approximately 65 million taxpayers, are only paying 3.5 percent of all federal income taxes, then many of these taxpayers are paying little or no income tax.

${ }^{85}$ Ibid., 201. 


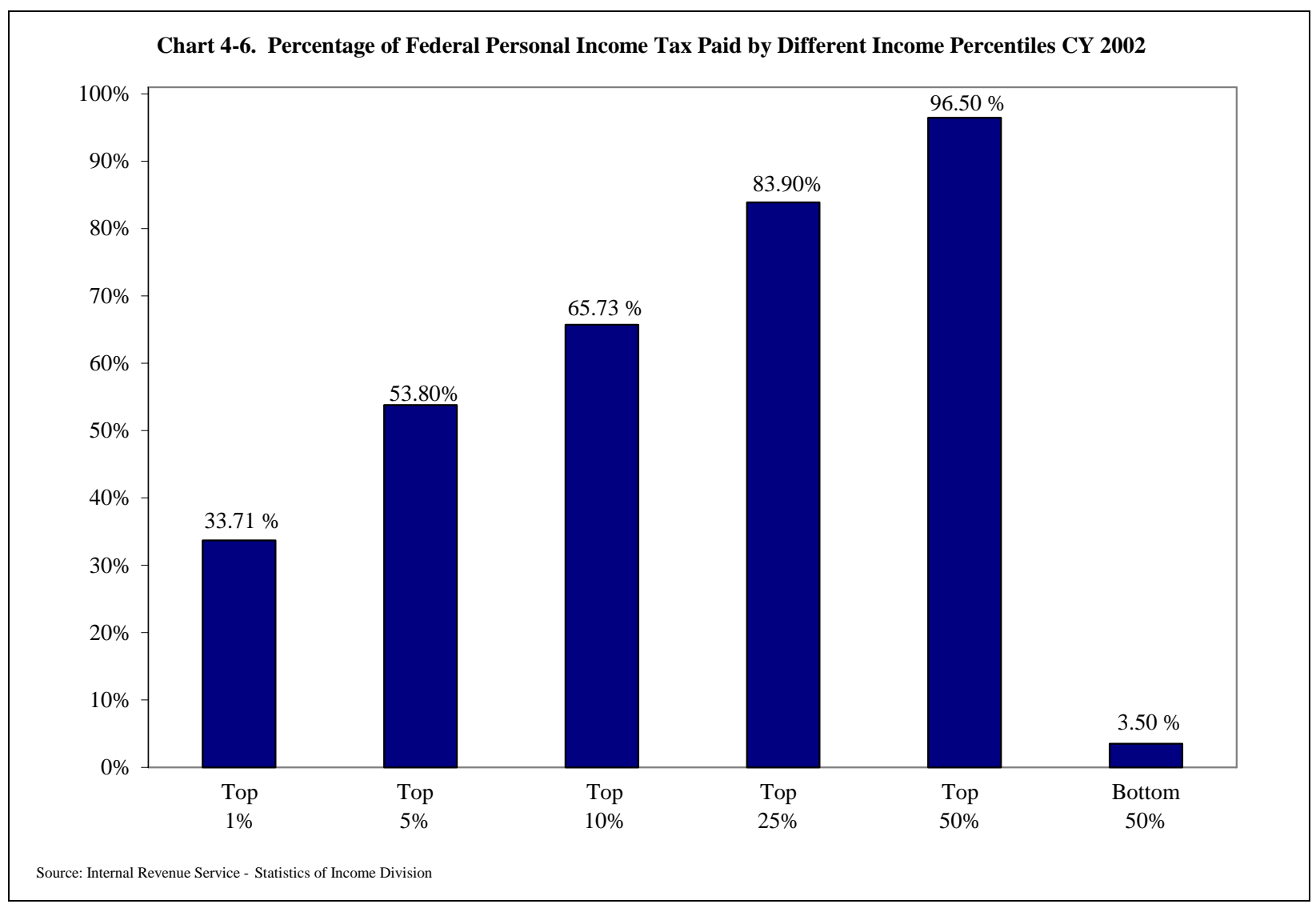

Income categories may be a convenient way of presenting snapshots of income data for a group of people at a certain point in time. Nonetheless, the notion of a quintile as a fixed economic class or social reality is a statistical mirage. Distributional tax tables do not currently purport to show how various tax legislation will affect the mobility of taxpayers (i.e., due to the components of the proposed tax legislation, how many taxpayers will move up the income ladder) or describe how the total number of taxpayers benefiting from a change in tax policy might be different using panel data as proposed to a snapshot. As a result, the reality of income mobility should be at least considered by analysts of tax distribution tables and by the public.

The Treasury Department is currently experimenting with tax distribution analysis based on a sample of panel data covering a 10-year period of 1987 through 1996 . Several government economists published results of an analysis of the Economic Growth and Tax Reconciliation Act of 2001 (EGTRRA) and the Jobs and Growth Tax Relief Act of 2003 (JGTRRA) using the Treasury panel data. ${ }^{86}$ As opposed to a cross-sectional analysis, use of the panel data for distribution analysis provided a better understanding of the total number of people that would be effected by the tax changes. For example, in one simulation, the authors found that while 84.5 percent of taxpayers benefited from at least one provision in EGTRRA and JGTRRA in the first year of the period under analysis, 94.4 percent benefited in at least one year during the entire period under analysis (period of analysis was 2004 - 2013).

\footnotetext{
${ }^{86}$ Julie-Anne Cronin, Janet Holtzblatt, Gillian Hunter, Janet McCubbin, James R. Nunns, and James Cilke, “Treasury’s New Panel Model for Tax Analysis,” Prepared for the $96^{\text {th }}$ Annual Conference on Taxation, National Tax Association, Chicago, Il.. November 15, 2003, 18.
} 


\section{Statistical STANDARDS, SAMPLing AND ACCURACY}

All distributional tax tables constructed and released by the Treasury's Office of Tax Analysis, the Joint Committee on Taxation, the Congressional Budget Office and the various interest groups are all based on one or more statistical samples. None of the distribution tables are based on a pure census of the population. These tables are based on sample surveys that inevitably have limitations. These limitations are routinely disclosed by statisticians. Furthermore, government policy requires that government agencies disclose such data limitations when information based on sample surveys are released to the public. ${ }^{87}$

A sample is a portion of a population that is examined or tested in order to obtain information or draw conclusions about the entire population. ${ }^{88}$ Every statistical sample inherently contains some amount of error. Each statistic or estimate generated from a sample has a measurable precision, or sampling error, that may be expressed as a plus or minus figure. Sampling error indicates mathematically how closely the estimated number is to the actual number that would result if a database were constructed consisting of the entire population.

Using monthly employment and jobs statistics as an example, the confidence interval for the monthly change in total employment from the household survey released by the Bureau of Labor Statistics (BLS) is on the order of plus or minus 376,000, at a 90-percent level of confidence. ${ }^{89}$ Suppose the estimate of total employment provided by the sample increases by 100,000 from one month to the next. The 90-percent confidence interval on the monthly change would range from $-276,000$ to $476,000(100,000+/-376,000)$. These figures do not mean that the sample results are off by these magnitude, but rather that there is about a 90 percent chance that the "true" population over-the-month change lies within this interval.

In other words, a confidence interval at the 90-percent confidence level means that 90 out of 100 instances, the sampling procedure used would produce a confidence interval containing the population value that is being estimated, in this case change in employment. For this example, since the confidence interval includes values of less than zero and includes zero itself, it cannot be said with certainty that employment had, in fact, increased. Hence, in order to effectively analyze results derived from sample data, it is necessary to take into account the confidence level and confidence interval. The same applies to tax statistics that result from sample studies, as is explained in more detail below.

All of the distributional tax tables constructed by the Treasury's Office of Tax Analysis, Joint Committee on Taxation, Congressional Budget Office, and lobbying organizations base their estimates on a sample database constructed by the Internal Revenue Service - Statistics of

\footnotetext{
${ }^{87}$ United States Office of Management and Budget, Executive Office of the President, "Circular No. A-130," Appendix IV, Section 8a(7) (February 1996).

Available on-line at: http://www.whitehouse.gov/OMB/circulars/a130/a130.html

${ }^{88}$ United States General Accounting Office, Using Statistical Sampling, GAO/PEMD-10.1 (May 1992).

${ }^{89}$ United States Department of Labor, Bureau of Labor Statistics, “The Employment Situation: April 1997," News Release.
} 
Income Division (SOI). ${ }^{90}$ Since the numbers presented in distributional tax tables are estimates based on a sample of tax returns, they are subject to sampling error.

To properly use the estimates presented in any distribution table, as noted above, the magnitude of the potential sampling error must be known in order to make any informed views relating to the significance of the estimates presented. The SOI Division, as any reputable statistical agency does, stresses in every article it publishes that its estimates are based on a sample and that the statistics presented are only estimates and are subject to error. Hence, all numbers must be analyzed within the context of the sampling error. The SOI Division is so strongly committed to the transparency of its work and the importance of viewing estimates within the context of sampling error that it either publishes, or makes available to the public, tables that openly provide the coefficients of variation (a measure of sampling error). ${ }^{91}$

In fact, an omission of such information could be in violation of government policy. According to the U.S. Office of Management and Budget (OMB), an agency within the Executive Office of the President with responsibility for overseeing Federal regulations and developing policies to improve government statistics: "Agencies should inform the public as to the limitations inherent in the information dissemination product (e.g., possibility of errors, degree of reliability, and validity) so that users are fully aware of the quality and integrity of the information." ${ }^{\prime 2}$

Unfortunately, such important information is missing from tax distribution tables. The omission of these data, which would help determine the accuracy of the estimates, only hinders the policy debate and furthers the illusion of precision surrounding the estimates. If the public understood that the numbers are subject to sampling error, the reliability of these data would then be subject to question. Table 4-7 below details by how much estimates for the number of returns and the amount of tax generated from the SOI sample can vary due to sampling error based on a 95percent level of confidence.

\footnotetext{
${ }^{90}$ Only government agencies that are given authority under law have access to individual taxpayer records, or microdata. All other parties, including lobbying organizations, must use SOI's public-use file, which is sanitized so that no information can be directly or indirectly identified to individual taxpayers.

${ }^{91}$ In SOI reports, the standard error is not directly presented. Instead, the ratio of standard error to the estimate itself is presented in percentage form. This ratio is called the coefficient of variation (CV). The user of SOI data has to multiply an estimate by its CV to recreate the standard error and to construct confidence intervals. For example, if a sample estimate of 150,000 returns is known to have a coefficient of variation of 4-percent at a 68-percent confidence level (one standard deviation), then the following arithmetic procedure would be followed to construct a 68-percent confidence interval estimate (for a 95-percent confidence interval - two standard deviations, double the 68-percent coefficient of variation amount):

then:

$\begin{array}{cl}150,000 & \text { (sample estimate) } \\ + \text { or }-6,000 & \text { (standard error) }\end{array}$

$=[144,000-156,000] \quad$ (68-percent confidence interval)

${ }^{92}$ United States Office of Management and Budget. Executive Office of the President.

Circular NO. A-130. Appendix IV, Section 8a(7). February 1996.

Available on-line at: http://www.whitehouse.gov/OMB/circulars/a130/a130.html (Emphasis added)
} 


\begin{tabular}{|l|r|r|r|r|r|r|r|r|}
\hline \multicolumn{7}{|c|}{ Table 4-7. Coefficients of Variations and Confidence Intervals for Selected Items, Tax Year 2001 - Modified Taxable Income - (Amounts in Thousands, except } \\
percentages)
\end{tabular}

Although publishing coefficients of variation (CV) for estimates provides the user with a measure of accuracy, it does not provide effortless transparency. A person would have to go through the mathematical calculations described in the footnote above in order to derive the information similar to that which is presented in Table 4-7. Additionally, CVs do not provide an easy way to perceive the measure of variation. Table 4-7 shows that based on both a nominal and percentage basis the variation between income ranges varies greatly. Focusing on the column for "Tax Generated Amount," the CV for those taxpayers with an AGI under \$2,000 is 6.93 percent $(+/-)$ at a 68-percent confidence interval. For a 95-percent confidence interval, double the CV amount.

However, the amount of tax generated can vary by $\$ 3,712$, or 13.86 percent $[(28,645$ - 24-933) / 24,933)]. Again, for a 95-percent confidence interval double these amounts. The CV associated with tax generated amount (tax liability) for those taxpayers with an AGI of between $\$ 500,000$ and $\$ 1,000,000$ is 0.98 percent and the amount of tax liability varies by $\$ 1,336,608$, but only 2.0 percent [(68,862,596 - 67,525,988) / 67,525,988]. Although the absolute variation for tax liability in dollars is higher for the highest income group, the highest income group has the lowest percent of variation. However, the lowest income group has the highest percent variation. This fact calls into question the precision of any report based on SOI data that claims that the lowest income groups are losers under a particular tax reduction proposal since, based on the SOI data alone, the variation of some estimates of tax liability can vary by almost 14 percent (28 percent at a 95-percent confidence interval).

It has just been demonstrated that in order for readers to make informed decisions regarding the accuracy of a given set of statistics, it is necessary for the agencies or groups responsible for the release of statistical tables to publish some type of companion table providing measurement of error. In order to meet the reasonable standards of statistical integrity, every government publication based on statistical sampling should also provide companion information to the public on possible measurement errors. 


\section{Statistical Accuracy and Reliability Combining Data Sets of DIFFERENT SAMPLE DESIGNS}

Mixtures from different sources can produce results that are less than the sum of its parts. For example, if grammatical Chinese is mixed with grammatical German, the results are likely to be a hybrid that would be neither grammatical nor intelligible. A similar problem emerges from efforts to combine different statistical samples. Individual statistical samples by themselves can be accurate and reliable. However, if different samples are combined in order to impute additional variables, the result is not necessarily a reliable and accurate sample, but more likely a statistically compromised sample from which it is impossible to provide accurate measures of error and reliability. This is exactly what many producers of tax distribution tables do in order to develop the data sets used to construct tax models and produce tax distribution tables. Consequently, when tax distribution tables based on statistically compromised data are released, there is no way of knowing how accurate these statistics are.

Consider the following simple example: Suppose a team of economists was interested in federal income tax paid and level of education by zip code. Assume that the variable for federal income tax paid was only available from the SOI sample data of tax returns. Furthermore, assume that the variable for education was only available from the Census Bureau's Current Population Survey (CPS). For a particular zip code, the economists estimate that the percentage of persons with federal income tax payments over $\$ 10,000$ is 50 percent (from the SOI data set) for a particular zip code, while the percentage of persons with a college degree is 30 percent (from the CPS data set) for that same zip code. The economists may be tempted to conclude that the percentage (or joint distribution) of persons in the zip code that have a college degree with federal income tax payments over $\$ 10,000$ is 15 percent (50\% x 30\% = 15\%).

However, the only way for this inference, or imputed value, to be accurate is if federal income tax payments and education are statistically independent. If they are not, which is the case in this example, then the conditional probability needs to be computed, e.g., what is the probability of having a federal income tax payment over $\$ 10,000$ given that a person has a college degree. To accurately arrive at this statistic, both variables would have to be included in a single and complete sample, not derived from a merged sample consisting of two different samples of different sample designs. Only then could the economists determine the number of persons that have federal income tax payments over $\$ 10,000$ with a college degree.

The fallacies of combining statistics from different samples can best be illustrated using the old discipline, reductio ad absurdum; i.e., if one sample study indicates that 50 percent of Americans own stocks either directly or through stock mutual funds and another sample study indicates that 10 percent of Americans have income over $\$ 100,000$, it would be silly to combine the two results and argue that only 5 percent of Americans with income over $\$ 100,000$ own stocks (50\% x 10\% $=5 \%) !^{93}$

\footnotetext{
${ }^{93}$ A study by the Investment Company Institute and the Securities Industry Association found that 49.2 million, or 48.2 percent, of all U.S. households owned equities in early 1999 or 78.7 million individuals. Additionally, of U.S. households with income of $\$ 100,000$ or more, 67 percent owned individual stock and 88 percent owned stock mutual funds. Equity Ownership in America. Fall 1999, pages 5 and 71.
} 
As illustrated above, statistical samples generally should not be merged together if the samples have different sample designs and the data were collected under different conditions. If there are differences in the sample designs and sampling conditions, the samples normally cannot be combined, as the results would not be statistically accurate or reliable. Furthermore, measurements of error cannot mathematically be calculated for sample data resulting from the combination of two totally different samples. However, many producers of tax distribution tables violate this principle in constructing tax models and producing tax distribution tables.

To use OTA's FEI concept as one example, OTA bases its data set on SOI's sample of individual tax returns. SOI's data is based on taxpayers, not families - the unit of analysis for OTA's tax model. In order to construct families out of taxpayers, OTA combines data from the Current Population Survey (CPS) released by the Census Bureau. CPS data contain information on nonfilers, nontaxable sources of income and family structure. OTA further adds to its data set by drawing information from the Consumer Expenditure Survey (CES) released by the Bureau of Labor Statistics, the IRS' Taxpayer Compliance Measurement Program (TCMP) and the Federal Reserve Board's Survey of Consumer Finances.

All of these data sources have different sample designs, sample different populations and are conducted at different points in time. Extensive imputations are added to the Treasury's data set based on all of these mutually exclusive samples of different sample designs. Because these mutually exclusive samples are merged, there is no way to measure the accuracy and reliability of the estimates based on these combined data.

As then OTA Director of Tax Analysis James R. Nunns observed, "The accuracy of the matching and imputation procedures cannot be independently verified, because no single data source contains all of the income, consumption, and wealth data necessary for such a verification. For distributional purposes, however, the methods need only provide a reasonable accurate distribution of certain variables by broad family economic income classes."94

However, one cannot objectively define "reasonable" when it is impossible to measure accuracy. Estimates released based on a statistically compromised tax model do not meet the statistical standards by which every other government statistical agency adheres. Although imputations are made for all income categories, the imputations made to create an income concept like the FEI add "income" with disproportionately large amounts allocated to the middle and upper income categories (those Americans that pay the vast majority of tax). This has the effect of making the middle and upper income groups appear to be "richer" than they actually are while simultaneously making the lower income groups (those that may not incur tax liability) appear to be less well off, thus portraying the tax code as overly regressive.

\footnotetext{
${ }^{94}$ James R. Nunns, "Distributional Analysis at the Office of Tax Analysis," in Distributional Analysis of Tax Policy, (Washington, DC: AEI Press, 1995), 113 (Emphasis added.)
} 


\section{CHAPTER 5 -HOW TAX DisTRIBUTION TABLES ARE USED/MISUSED IN TAX POLICY \& Why A TOOL FOR EVAluATING TAX DISTRIBUTION TABLES IS NEEDED}

Chapter 4 discussed the nuances of how different presentations of data and methodological approaches to distributional analysis can affect perspectives. Having the necessary background information presented in Chapter 4, Chapter 5 provides a clear example of how tax distribution tables are used/misused in tax policy debates. Further, this chapter sets out to demonstrate how tax distribution tables are used as tools of strategic management and to demonstrate the need for a new tool of policy analysis to evaluate tax distribution tables.

In isolation, a tax distribution table is a poor and incomplete tool to test the merits and fairness of proposed changes to tax policy. A change in tax policy should not be judged solely on the grounds of whether or not it benefits one income group more than another. No distribution table can be perfect or present every nuance associated with estimated changes in the distribution of taxes. It is possible to include enough information so that the results are not presented in a biased or misleading manner; although there is little assurance they will not be interpreted and reported in a biased and misleading manner. Until distribution tables are either abandoned or reformed, the best defenses against misleading tables are education and full disclosure of information.

The debate surrounding President George W. Bush's tax plan of 2001 is a prime example of how the use of tax distribution tables can provide an incomplete and distorted picture and clearly demonstrates the need for a new tool of policy analysis to evaluate tax distribution tables. For this tax proposal, numerous distribution tables were prepared by the Joint Committee on Taxation of the U.S. Congress, the Office of Tax Analysis of the U.S. Department of the Treasury, advocacy groups and think tanks. These tables were routinely published in major newspapers around the country. ${ }^{95}$ However, without a proper understanding of what these distribution tables show, many important issues were misinterpreted or ignored altogether. These same issues are sure to rise again as tax policy proposals are debated in the future.

By comparing distribution tables that provide alternative perspectives of President Bush's tax plan of 2001, this chapter illustrates how tax distribution tables often can provide misleading results about the impact of pending tax legislation. Distribution tables typically are defective in several ways that, once recognized, raise serious questions about their value to policymakers and the public.

The following two distribution tables are examples of distribution tables released into the public domain that analyzed various aspects of President George W. Bush's tax plan as it developed.

\footnotetext{
${ }^{95}$ See, for example: Jacob Schlesinger and John McKinnon, "Bush Plan Gives Rich Biggest Cut in Dollars But Not in Percentage," The Wall Street Journal, November 5, 2000; Steven Pearlstein and Paul Blustein, "On the Class Warpath," The Washington Post, February 7, 2001; Shailah Murray and David Rogers, "Democrats Attempt to Draw Rein As Republicans Study Wish Lists,” The Wall Street Journal, February 8, 2001; Glenn Kessler, "Treasury's Tax Cut Data Can Cut 2 Ways," The Washington Post, March 9, 2001; David Cay Johnston, "Even for Wealthy, Tax Plan's Benefits Could Vary Widely,” The New York Times, May 15, 2001; and Glenn Kessler, “Tax Cut Debate’s Division Problem,” The Washington Post, May 17, 2001.
} 
The debate surrounding the 2001 tax plan, beginning with the 2000 presidential campaign of George W. Bush and advanced under his presidential administration, provides a unique opportunity to compare distribution tables released by a Democratic and Republican administration analyzing similar tax proposals.

As reported by the Washington Post in February 2001:

The legislative battle over the Bush tax plan will be waged on many fronts. Each side has think tanks or federal agencies that have cranked up their computers to spit out reams of data to demonstrate the essential fairness or unfairness of the $\$ 1.6$ trillion proposal...These “facts" aren’t necessarily false, but they often lack context—because that would detract from the political point being scored. ${ }^{96}$

Though the tables were not all prepared at the same time, the methodologies and presentations of data are consistent with those routinely used by the various groups and provide a useful illustration of the role distribution tables play in the tax policy process.

- Table 5-1 was prepared by the Treasury Department's Office of Tax Analysis (OTA 2000) under former President Clinton; and

- Table 5-2 was prepared by the Treasury Department's Office of Tax Analysis (OTA 2001) under President Bush.

The point of the demonstration in this chapter is not to focus on the numbers and outcomes of the analyses per se, but on what information is and is not presented and how the presentation of the information can alter perspectives of the burdens and benefits of the same plan. ${ }^{97}$ Further, this chapter demonstrates the need for a new tool of policy analysis for revealing and balancing the perspectives presented in tax distribution tables.

\footnotetext{
${ }^{96}$ Glenn Kessler, “Early Deductions: Despite What’s Said About Tax Cuts, Here’s What It Means,” The Washington Post, February 18, 2001.

${ }^{97}$ The Congressional Budget Office (CBO) did not prepare any tax distribution tables that were subsequently publicly released during this period. Hence, $\mathrm{CBO}$ is not represented below.
} 
Clinton Administration Office of Tax Analysis, Department of the Treasury:

Table 5-1. Major Provisions Passed by the House Ways and Means Committee ${ }^{1}$

(2000 Income Levels) Very Preliminary

\begin{tabular}{|c|c|c|c|c|c|c|}
\hline \multirow[b]{2}{*}{ Family Economic Income ${ }^{2}$} & \multirow[b]{2}{*}{$\begin{array}{l}\text { Number of } \\
\text { Families } \\
\text { (millions) }\end{array}$} & \multirow[b]{2}{*}{$\begin{array}{c}\text { Average Tax } \\
\text { Change (\$) }\end{array}$} & \multicolumn{2}{|c|}{ Total Tax Change } & \multicolumn{2}{|c|}{ Percent Change In: } \\
\hline & & & $\begin{array}{c}\text { Amount } \\
\text { (millions) }^{3}\end{array}$ & $\begin{array}{c}\text { Percent } \\
\text { Distribution (\%) }\end{array}$ & $\begin{array}{l}\text { Current Federal } \\
\text { Taxes }^{4}\end{array}$ & $\begin{array}{c}\text { After-Tax } \\
\text { Income }^{5} \\
(\%)\end{array}$ \\
\hline Lowest $^{6}$ & 22.4 & -13 & -286 & $0.4 \%$ & $-2.1 \%$ & $0.1 \%$ \\
\hline Second & 23.0 & -77 & $-1,762$ & $2.7 \%$ & $-2.5 \%$ & $0.3 \%$ \\
\hline Third & 23.0 & -192 & $-4,426$ & $6.8 \%$ & $-2.4 \%$ & $0.6 \%$ \\
\hline Fourth & 23.0 & -380 & $-8,748$ & $13.4 \%$ & $-2.4 \%$ & $0.6 \%$ \\
\hline Highest & 23.0 & $-2,164$ & $-49,877$ & $76.6 \%$ & $-4.2 \%$ & $1.4 \%$ \\
\hline Total $^{6}$ & 115.2 & -566 & $-65,131$ & $100.0 \%$ & $-3.6 \%$ & $1.0 \%$ \\
\hline Top $10 \%$ & 11.5 & $-3,442$ & $-39,586$ & $60.9 \%$ & $-4.5 \%$ & $1.6 \%$ \\
\hline Top 5\% & 5.8 & $-5,632$ & $-32,490$ & $49.9 \%$ & $-4.9 \%$ & $1.8 \%$ \\
\hline Top 1\% & 1.2 & $-17,074$ & $-19,840$ & $30.5 \%$ & $-5.5 \%$ & $2.2 \%$ \\
\hline
\end{tabular}

Source: Department of the Treasury. Office of Tax Analysis. July 17, 2000.

(1) This table distributes the estimated change in tax burdens due to the following major provisions passed by the House Ways and Means Committee in H.R. 7, H.R. 8, H.R. 2990, H.R. 3832, H.R. 3916, H.R. 4810 and H.R. 4843.

(2) Family Economic Income (FEI) is a broad-based income concept. FEI is constructed by adding to AGI unreported and under-reported income; IRA and Keogh deductions; nontaxable transfer payments such as Social Security and AFDC; employer-provided fringe benefits; inside build-up on pensions; IRAs, Keoghs, and life insurance; tax-exempt interest; and imputed rent on owner-occupied housing. Capital gains are computed on an accrual basis, adjusted for inflation to the extent that reliable data allow. Inflationary losses of lenders are subtracted and gains of borrowers are added. There is also an adjustment for accelerated depreciation of noncorporate businesses. FEI is shown on a family rather than a tax-return basis. The economic incomes of all members of a family unit are added to arrive at the family's economic income used in the distributions.

(3) The change in Federal taxes is estimated at 2000 income levels assuming fully phased in law. Current and proposed taxes are estimated using FY2000 Budget assumptions. The tax benefit of the increase in retirement contribution limits is measured as the present value of tax savings on one year's contributions.

(4) The taxes included are individual and corporate income, payroll, excises, customs duties, and estate and gift taxes. The individual income tax is assumed to be borne by payers, the corporate income tax by capital generally, payroll taxes (employer and employee shares) by labor (wages and self-employment income), excises on purchases by individuals in proportion to relative consumption of the taxed good and proportionately by labor and capital and excises on purchases by businesses and customs duties proportionately to labor and capital, and the estate tax by decedents. Federal taxes are estimated at 2000 income levels but assuming 2009 law and, therefore, exclude provisions that expire prior to the end of the Budget period and are adjusted for the effects of unindexed parameters.

(5) After-tax income is Family Economic Income less current Federal taxes.

(6) Families with negative incomes are excluded from the lowest quintile but included in the total line.

NOTE: Quintiles begin at FEI of: Second \$17,988; Third \$34,844; Fourth \$59,019; Highest \$100,767; Top 10\% \$140,581; Top 5\% \$189,835; Top $1 \% \$ 462,053$.

Table 5-1 was prepared by the OTA under the Clinton Administration and during the presidential campaign of 2000. Unlike the table prepared by the JCT, OTA prefers to categorize the units of analysis as families (not taxpayers like the JCT) and place them into quintiles based on economic income, not dollar income levels. This has the effect of broadening the unit of analysis and lumping together as "families" many taxpayers that are traditionally not considered families, such as single taxpayers.

The OTA use of families as an income concept groups together tax units with very different tax liabilities and different abilities to pay. For example, the OTA aggregates the income of all tax filers in a household into a single-family unit. This means that the income of dependents that file tax returns is added to the income of the primary taxpayers. Therefore, a single "family" taxpayer with $\$ 50,000$ of income would be categorized in the same group as a family with both spouses earning $\$ 20,000$ and a dependent child earning $\$ 10,000$, for a combined "family" income of $\$ 50,000$. Though these two "families" have similar income, they have much different 
abilities to pay to bear a tax burden. Though this critique can also partly be said of the JCT unit of analysis (tax filing unit), the impact is much greater with the use of "families" as the unit of analysis. This use of "families" further makes it difficult to judge both the horizontal and vertical equity of the proposed changes to tax policy on individual taxpayers. ${ }^{98}$

The main columns of interest in the 2000 OTA table are the "Average Tax Change" and the two columns under "Total Tax Change." The 2000 OTA analysis shows lower income groups receiving what looks like a pittance in income tax relief, while upper income groups receive what appears to be a disproportionate amount of tax relief. The perception that the income tax relief is skewed toward the rich is further emphasized in the last column relating to the percent change in after-tax income.

The 2000 OTA analysis shows that lower income groups would receive substantially less of a change in their after-tax income than higher income levels. However, this is primarily due to the current progressive nature of the U.S. income tax system whereby lower income groups pay little or no federal income taxes. ${ }^{99}$ In fact, an estimated 50.6 million tax returns, or 35.6 percent of all tax returns, had zero or negative income tax liability in $2001 .^{100}$ Though an OTA paper released under the Clinton administration states "the only tax burden measure with some theoretical basis is the percentage change in after-tax income," 101 focusing solely on changes in after-tax income can be misleading because it implies that the amount of taxes currently paid is irrelevant to judging the equity of a proposed tax cut.

For example, Chart 5-1 shows that the entire bottom half (bottom 50 percent) of taxpayers who reported positive AGI paid 3.97 percent of all individual federal income taxes in 2001. This means that the top half of all taxpayers paid 96.03 percent of all individual federal income taxes. Moreover, the top 1 percent of taxpayers paid 33.89 percent, the top 5 percent paid 53.25 percent and the top 10 percent paid 64.89 percent (almost two-thirds of all federal individual income taxes of taxpayers). It is virtually impossible to provide a federal income tax cut that does not benefit the top half of taxpayers, since they account for virtually all federal income taxes paid. The bottom half of taxpayers pay almost no federal income taxes, therefore it is difficult to provide meaningful tax cuts to this group of taxpayers.

\footnotetext{
${ }^{98}$ Horizontal equity refers to a principle of judging the fairness of taxation, which holds that taxpayers who have the same income should pay the same amount in taxes. Vertical equity is another principle of judging fairness and holds that, in a progressive tax system, taxpayers with higher incomes should pay higher levels of taxes.

${ }^{99}$ Joint Committee on Taxation. JCX-65-01. August 2, 2001.

${ }^{100}$ Ibid.

${ }^{101}$ Julie-Anne Cronin. “U.S. Treasury Distributional Analysis Methodology.” Office of Tax Analysis. Department of Treasury. OTA Paper 85. September 1999, page 34.
} 
Unlike the JCT analysis, the distribution table by the 2000 OTA presents the proposed tax plan as disproportionately skewed to the wealthy, thereby reducing the progressivity in the current tax system. However, without information on how much in income tax each income group currently pays, it is impossible to completely assess the fairness or equity of the tax plan. The 2000 OTA estimate omits such necessary information.

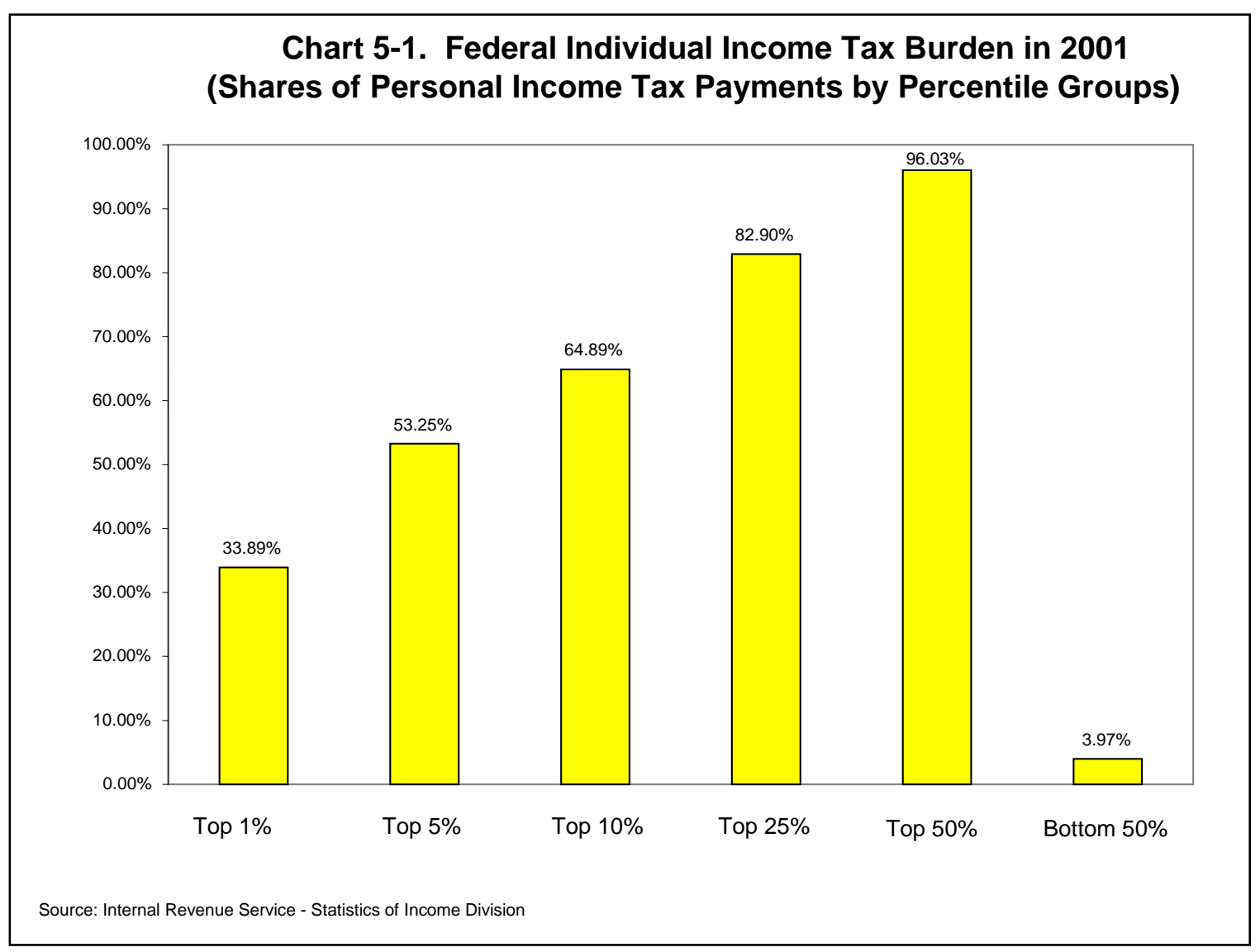

It is important to note another key difference between the JCT analysis and the 2000 OTA analysis. The 2000 OTA uses a very broad measure of income, which is unfamiliar to most Americans and even to many legislators. As discussed in Chapter 4, the "Family Economic Income" (FEI) concept used by the 2000 OTA is a broad-based income measure that economists refer to as the Haig-Simons income concept. The Haig-Simons income concept defines income as the "total value of rights exercised in the market, together with the accumulation of wealth in that period."102 Unlike items that make up adjusted gross income, such as wages, dividends and capital gains, the FEI concept is measured by adding to AGI such items as in-kind income (e.g., cash transfers and food stamps), imputed income from durable goods consumption (e.g., imputed rental income from an owner-occupied home), and accrued (i.e., unrealized) capital gains.

\footnotetext{
${ }^{102}$ Robert Murray Haig, "The Concept of Income: Economic and Legal Aspects," in R.M. Haig (Editor), The Federal Income Tax. New York: Columbia University Press, 1921; and Henry C. Simons, Personal Income Taxation: The Definition of Income as a Problem of Fiscal Policy. Chicago: University of Chicago Press, 1938.
} 
As discussed in Chapter 4, the idea behind the Family Economic Income concept is to impute a cash measure including as income all forms of value that are not received in monetary form and are therefore not subject to taxation. In essence, the economic theory behind the imputation of income under the Haig-Simons income concept includes as "income" any flow of net value attributable to the consumption of all durable goods, such as houses, cars and washing machines. Under Haig-Simons, "the value of leisure and unpaid work (such as food grown for home use)" is also imputed as income to individuals and families. ${ }^{103}$ Besides the imputed value of owneroccupied housing, the Haig-Simons income concept includes an imputation for personal interest income, "which includes the benefits of banking services provided free to customers in lieu of interest."104 The Clinton OTA includes some types of imputed income in FEI (e.g., imputed rental income from owner-occupied housing) but not others (e.g., the value of leisure).

Additionally, FEI excludes in-kind transfers such as Medicare and Medicaid, which often benefit middle and lower income groups, even though the payroll taxes to fund these benefits are included in the 2000 OTA analysis of tax burden. The OTA's justification for excluding Medicare and Medicaid is based both on "the difficulty of assigning a value of benefits to the recipient, and the difficulty of properly identifying recipients.” ${ }^{105}$ However, OTA faces similar, if not more difficult, problems with imputing values for unreported income, income from people who do not file tax returns and rental income from owner-occupied housing. But these items are included in the OTA FEI concept. Many of the imputed additions to income that are included in the FEI concept consist of non-monetary items that have never, and could not logistically, be included in the tax base. If these items cannot be included in the tax base, it is questionable why such a measure is used at all for purposes of analyzing tax policy.

In short, the OTA family economic income concept and methodology used in the 2000 analysis inflates the income amounts for those families primarily included in the middle and upper income brackets while lowering their average tax rate. The opposite effect holds for the lower income groups. Hence, virtually any broad-based income tax reduction proposal as viewed under the 2000 OTA approach to tax distribution analysis would leverage the already skewed presentation to show even greater disproportionate benefits to the "wealthy" and even less progressivity of any proportional change.

Drawing from two back-to-back news reports in The Washington Post, a picture emerges on how the information in this table was portrayed. For example, "Fearing that they are losing the public relations battle over taxes, Clinton administration officials yesterday stepped up efforts to convince voters that the bevy of GOP-crafted tax bills racing through Congress would shower most of their benefits on the wealthiest Americans."106 Another article published the following day discussed how "Democrats also raised fairness issues: A new Treasury Department analysis of seven GOP tax measures that have passed the House Ways and Means Committee this year

\footnotetext{
103 Jane G. Gravelle. “Imputed Income.” In Joseph J. Cordes, Robert D. Ebel, and Jane G. Gravelle (Editors). The Encyclopedia of Taxation and Tax Policy. The Urban Institute Press, 1995, page 168.

104 Ibid.

105 Julie-Anne Cronin. “U.S. Treasury Distributional Analysis Methodology.” Office of Tax Analysis. Department of Treasury. OTA Paper 85. September 1999.

${ }^{106}$ Glenn Kessler and Eric Pianin, “White House Strikes Back on Tax Cuts,” The Washington Post, July 18, 2000.
} 
said that together, 76 percent of the cuts would go to the 23 million wealthiest families. The remaining 96 million families would get just over 23 percent.”"107

These are just two examples of how the tax distribution table released by the Clinton administration OTA contributed to the way the tax legislation was portrayed in the public arena. This table was also covered by other media outlets, in editorials and opinion pages, in press releases issued by advocacy groups, and in congressional floor speeches. In the dissertation, examples of all these types of coverage will be provided as evidence to demonstrate how important tax distribution tables have become to tax policy and to further demonstrate how the presentation of results can influence and shape perspectives.

Bush Administration Office of Tax Analysis, Department of the Treasury:

Table 5-2. Major Individual Income Tax Provisions of the President's Tax Proposal ${ }^{1}$

\begin{tabular}{|c|c|c|c|c|c|}
\hline \multirow[b]{3}{*}{ Cash Income Class ${ }^{2}$} & \multirow{3}{*}{$\begin{array}{c}\text { Distribution of } \\
\text { Proposed } \\
\text { Changes in } \\
\text { Individual } \\
\text { Income Taxes } \\
(\%) \\
\end{array}$} & \multicolumn{2}{|c|}{ (2000 Income Levels) } & \multirow{3}{*}{$\begin{array}{c}\text { Average Individual } \\
\text { Income Taxes With } \\
\text { Proposed Changes } \\
\text { (\$) }\end{array}$} & \multirow{3}{*}{$\begin{array}{l}\text { Percent Change in } \\
\text { Individual Income } \\
\text { Taxes } \\
(\%)\end{array}$} \\
\hline & & $\begin{array}{r}\text { Distribution of } \\
\text { Income }\end{array}$ & $\begin{array}{l}\text { otal Individual } \\
\text { Taxes }^{3}\end{array}$ & & \\
\hline & & $\begin{array}{c}\text { Current Law } \\
(\%)\end{array}$ & $\begin{array}{c}\text { With Proposed } \\
\text { Changes }{ }^{4} \\
(\%)\end{array}$ & & \\
\hline $0-30$ & 9.3 & -1.0 & -2.8 & -457 & -136.2 \\
\hline $30-40$ & 6.5 & 2.5 & 1.8 & 993 & -38.3 \\
\hline $40-50$ & 7.8 & 4.1 & 3.4 & 2,210 & -28.0 \\
\hline $50-75$ & 17.2 & 12.2 & 11.3 & 4,279 & -20.8 \\
\hline $75-100$ & 13.6 & 12.2 & 12.0 & 7,848 & -16.3 \\
\hline $100-200$ & 19.8 & 27.1 & 28.3 & 16,625 & -10.7 \\
\hline 200 \& Over & 25.4 & 42.9 & 45.9 & 103,931 & -8.7 \\
\hline Total $^{5}$ & 100.0 & 100.0 & 100.0 & 6,322 & -14.6 \\
\hline
\end{tabular}

Source: Department of the Treasury. Office of Tax Analysis. March 8, 2001.

(1) The major individual income tax provisions are: i) lower individual income tax rates; ii) increase the child credit to $\$ 1,000$, raise the income level at which it phases out, and allow the child credit against the AMT; iii) allow a 10\% deduction for the earnings of the lower earning spouse (up to \$30,000) in two-earner families; iv) allow taxpayers who do not itemize to deduct charitable contributions up to the amount of the taxpayer's standard deduction; and v) provide a refundable tax credit for individually-purchased health insurance.

(2) Cash Income consists of wages and salaries, net income from a business or farm, taxable and tax-exempt interest, dividends, rental income, realized capital gains, cash transfers from the government, and retirement benefits. Employer contributions for payroll taxes and the federal corporate income tax are added to place cash on a pre-tax basis. Cash income is shown on a family rather than on a tax return basis. The cash incomes of all members of a family are added to arrive at a family's cash income used in the distributions.

(3) The refundable portions of the earned income tax credit (EITC) and the child credit are included in the individual income tax. Federal taxes are estimated at 2000 income levels but assuming fully phased in law and, therefore, exclude provisions that expire prior to the end of the Budget period and are adjusted for the effects of unindexed parameters.

(4) The change in Federal taxes is estimated at 2000 income levels assuming fully phased in law.

(5) Families with negative incomes are excluded from the lowest income class but included in the total line.

The table produced by the OTA in 2001 takes a markedly different approach from the table produced by the 2000 OTA. The FEI concept and quintiles were replaced by a cash income concept and dollar income ranges similar to that utilized by the JCT. Additionally, this table presents some new information. For starters, the last column of the 2001 OTA table presents the "Percent Change in Individual Income Taxes." This column shows that the proposed tax cuts fall as a percentage of income as income rises. Therefore, in percentage terms, the lower income groups would benefit substantially relative to the higher income groups. As opposed to emphasizing the average tax benefit that would result to each income group, the 2001 OTA table

${ }^{107}$ Eric Pianin, “Senate Votes ‘Marriage Penalty’ Relief,” The Washington Post, July 19, 2000. 
shows the percentage reduction in taxes each group will pay after the tax change. As with the JCT tables, the inclusion of income tax shares is an advancement in distributional analysis.

Also, in the second to last column, the table provides the estimated average amount of individual income taxes that would be paid under the proposed tax plan. Presenting the data in this manner, as opposed to showing only the average tax cut, shows that a member of the lowest income group would actually receive a negative tax (mainly due to the refundable portions of the Earned Income Tax Credit and proposed changes to the Child Tax Credit), while a member of the highest income group would pay on average more than $\$ 100,000$.

Like the JCT analysis and as explained earlier, the 2001 OTA analysis excludes the estate and gift taxes from its analysis due to the uncertainty of the incidence. Also, the 2001 OTA analysis excludes other federal taxes from the analysis, such as payroll taxes paid by employees, though it adds the portion of payroll taxes paid by employers to employee income to place cash on a pretax basis. Some economists believe that all forms of taxes (income, payroll, excise, etc.) should be included in any analysis of tax policy in order to get a total understanding of the burden of taxation, since many lower income earners pay more in payroll taxes than in income taxes. However, other economists have argued that payroll taxes should be excluded from income tax analysis because payroll taxes and excise taxes are designed to pay for a present or future benefit to the payer not reflected in the analysis, whereas income taxes finance general expenditures.

Regardless, if payroll taxes are included in the income tax analysis then, at the very least, an estimate of the benefits associated with social insurance programs should be included in any distribution analysis, either as income or as a net against payroll taxes paid. As Michael J. Graetz writes,

As tax-policy analysts know, when viewed in isolation the social security payroll tax is regressive, but when benefits are taken into account, the social security system is quite progressive. Nevertheless, estimates of the existing tax burden and of changes in tax burdens since 1977 (frequently used as a baseline by CBO) or since 1980 (which marks the beginning of the Reagan administration) routinely include payroll taxes without indicating the benefits that they finance. ${ }^{108}$

The table produced by the OTA in 2000 makes the tax plan appear to overly benefit the wealthy and give virtually nothing to the lower income groups. In contrast, the presentation of the data in the 2001 OTA table counters opponents of President Bush's tax plan who contend that it overly and unfairly benefits the wealthy. Even though the Bush administration continues to release OTA distribution tables, the administration has publicly questioned the limitations of distribution

\footnotetext{
${ }^{108}$ Michael J. Graetz. "Distributional Tables, Tax Legislation, and the Illusion of Precision.” In David F. Bradford (Editor). Distributional Analysis of Tax Policy. AEI Press. Washington, DC. 1995, page 66.
} 
tables and noted that a one-year snapshot of the distributional effects of proposed tax legislation can be misleading. ${ }^{109}$

To provide just one piece of evidence to show how the Bush administration OTA table was portrayed, The Washington Post reported that "Democrats say that a tax cut that rewards such a small sliver of society is unfair to the millions of Americans who will receive little or nothing under the bill. Republicans argue that the wealthy pay most of the income taxes, and so it is only fair that they should reap most of the benefits of a tax cut." ${ }^{110}$ The Post further reported that "The White House and Treasury Department also have countered Democratic claims of unfairness by releasing analyses that, upon closer inspection, minimized the benefits to the wealthy."111

To summarize, the table produced by the 2000 OTA under the administration of President Clinton while then Vice President Gore was running for president makes the tax plan advocated by then candidate George W. Bush appear to overly benefit the wealthy and give virtually nothing to the lower income groups. Since the tax plan under analysis did not advance liberal preferences towards equal distribution of after-tax income, the 2000 OTA table appears designed to oppose the Bush tax plan.

In contrast, the presentation of the data in the 2001 OTA table under the administration of President George W. Bush counters opponents of President Bush's tax plan who contend that the tax plan overly and unfairly benefits the wealthy. It appears that the two different tables produced by the same organization, but under different administrations, were designed not to present "facts" to illuminate the public debate on the pros and cons of the Bush tax plan, but rather to support political tax policy positions.

The very fact that the same government organization (OTA) produced alternate and seemingly contradictory tax distribution tables depending upon the political party in control of the White House demonstrates the importance of tax distribution tables in tax policy debates and as a tool of strategic management. An index for evaluating the presentation of data within tax distribution tables, such as the TDTSI, would improve transparency and allow end-users a method for identifying misleading information.

The example in this chapter has demonstrated how tax distribution tables are often presented in manners that fail to provide a balanced and accurate perspective of tax policy. Unless there is greater public recognition of both the art and the science of distributional analysis, tax policy will be unduly influenced by misleading tax distribution tables. Although what is considered fair depends on philosophical and ethical judgments over which people can disagree, the presentation of tax data within distribution tables often hides or omits much of the important information that is required in order to effectively evaluate the merits of any proposed tax legislation.

\footnotetext{
${ }^{109}$ Council of Economic Advisers, Executive Office of the President, The Annual Report of the Council of Economic Advisers, together with the Economic Report of the President. U.S. Government Printing Office. Washington, DC. February 2003, Chapter 5.

${ }^{110}$ Glenn Kessler, “Tax Cut Debate’s Division Problem,” The Washington Post, May 17, 2001.

${ }^{111}$ Ibid.
} 
Scholars might argue that tax distribution tables cannot accurately summarize the complex and dynamic nature of income and wealth in the economy. ${ }^{112}$ Other scholars might argue that due to the current opaque nature of communicating even the simplest facts about tax policy to the American public, tax distribution tables should be abandoned as a basis for legislative decisionmaking. ${ }^{113}$ At the very least, the discussion presented throughout this analysis demonstrates that the process, development, presentation and release of tax distribution tables are in need of fundamental reform.

A more transparent dissemination of data and an insightful understanding of the "tricks of the trade" will enable policymakers and the general public to better understand tax distribution tables, make informed decisions about the merits of proposed tax legislation and promote a better understanding of tax policy. Hopefully, the end result will be more informed public debates and better tax policy decisions.

Given that it is highly unlikely that the use of distribution tables will be abandoned, the best recommendation is that the public should demand full disclosure of any and all relevant data. Full disclosure includes, at the very least, using income measures that are understood by the public (like cash income or adjusted gross income), providing median values as well as averages, fully describing any imputations, conducting sensitivity analyses, disclosing measures of variance, and fully explaining the limitations of the data and subsequent distribution tables. But how is the public supposed to know what questions to ask and what data to demand?

A new tool of policy analysis is needed to evaluate tax distribution tables and reveal the perspectives that are often hidden just beneath the surface. The Tax Distribution Table Scoring Index (TDTSI) offered in this dissertation provides the necessary tool for policymakers and the public to effectively balance the different perspectives presented by opposing tax distribution tables.

\footnotetext{
112 See, for example: Diana Furchtgott-Roth. “Abuses of Income Distribution Tables in Tax Policy.” Tax Notes. December 11, 1995.

113 See, for example: Michael J. Graetz. “Distributional Tables, Tax Legislation, and the Illusion of Precision.” In David F. Bradford (Editor). Distributional Analysis of Tax Policy, pages 75 and 76.
} 


\section{CHAPTER 6 - TAX DISTRIBUTION TABLE SCORING INDEX (TDTSI) - A NeW Tool of Policy Analysis to Evaluate Tax DISTRIBUTION TABLES}

Chapter 4 discussed the nuances of how different presentations of data and methodological approaches to distributional analysis can affect perspectives. Chapter 5 provided a clear example of how tax distribution tables are used in the tax policy process as tools of strategic management analyzing two different tax distribution tables released the Treasury Office of Tax Analysis (OTA); one table released under the Clinton administration in 2000 and the other table released under the Bush administration in 2001. The case was made that a new tool of policy is needed to evaluate tax distribution tables - a tool that would provide balance to the different perspectives presented by the multitude of distribution tables that are used to influence debate.

Chapter 6 describes this new tool, the Tax Distribution Table Scoring Index (TDTSI). Although the design of the TDTSI is discussed in detail in Chapter 3, a repeat of some of the discussion from Chapter 3 is useful to again place the TDTSI into context. Following is a general description of the TDTSI. Also, as an example of how to apply the TDTSI to tax distribution tables, the TDTSI is used to evaluate the two opposing OTA tables presented in Chapter 5. Three different scoring methods are provided to show the face validity of the index. Chapter 7 then applies the TDTSI to tax distribution tables associated with specific tax legislation to more fully demonstrate the practical application of the TDTSI to policymakers and the public.

\section{A Tax Distribution Table Scoring Index as a Tool of Policy Analysis}

The utility of the TDTSI is as an evaluation tool for policymakers and the public to apply to tax distribution tables to reveal the perspectives presented and balance any misleading or biased presentations of data. Chapter 5 discussed how two different tables produced by the same government agency resulted in different perspectives, both potentially equally misleading. However, in day-to-day practice, policymakers and the public are not presented with a detailed text-based analysis of what is included or omitted in every distribution table that is released. Further, as accurately depicted in a Washington Post article, “...in the tax debate, numbers can be easily manipulated to make a rhetorical point, so cutting through the maze of facts and statistics is difficult."114 What is needed is an evaluation tool that can provide the basic level of information necessary to effectively reveal and balance alternate perspectives presented in tax distribution tables, without requiring lengthy text-based descriptions. The TDTSI is such an evaluation tool.

Again, as discussed in Chapter 3, a tax distribution table purports to show how various groups are affected from a proposed change to tax policy. The resulting analysis either shows that a proposed tax policy is (1) distributional neutral, meaning that every group benefits from a tax cut (or shares the burden of a tax increase) equally; or (2) that some groups benefit (or bear the burden) unequally over others. Whether or not a given policy proposal is "fair" depends on one's viewpoint of fairness. Generally, tax policy advanced by conservatives on the right has

${ }^{114}$ Glenn Kessler, “Tax Cut Debate’s Division Problem,” The Washington Post, May 17, 2001. 
been concerned with lowering tax burdens while tax policy supported by liberals on the left has sought to redistribute more of the burden of taxation onto those with upper-incomes.

Terms such as liberal or left and conservative and right are common descriptions used in political dialogue. Associations with these labels are relatively consistent over time. With respect to tax policy, liberals are more likely to favor policies that result in the redistribution of wealth and/or after-tax income. Conservatives are more likely to favor consumption taxes over income taxes and be concerned with the share of taxes paid by different groups and who bears the burden of paying for government.

If liberals and conservatives do indeed tend to exhibit these traits, then logically presidential administrations, advocacy groups and think tanks that are considered left-liberal or rightconservative reveal similar characteristics and, therefore, should have similar tax policy positions. Therefore, if distribution tables are less a tool of objective policy analysis and more a tool of political strategic management, then patterns should emerge that demonstrate how different methodologies, content and presentation of results define and shape how the perceived fairness of a tax policy is defined or viewed.

The Tax Distribution Table Scoring Index (TDTSI), composed of 10 questions, serves as a policy tool for evaluating tax distribution tables and illuminating elements of bias. The ten questions are currently structured to elicit affirmative responses if the variable under analysis tends to favor liberal tax policy views. Tables that provide affirmative scores for all ten questions would score a 10 , or $100 \%$, and would indicate that the distribution table under analysis is designed to present information that advances liberal tax policy positions (such as redistributing after-tax income) or to oppose conservative tax policy positions. Anything less than 10 , or $100 \%$, is a degree of being "less liberal." The scale is not intended to be an interval scale, but rather an ordinal scale where 10 is more than 1 but not necessarily ten times more.

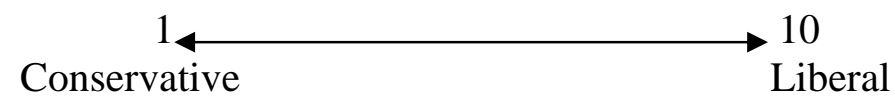

The main benefit of this method is its simplicity. The responses are summed and the result can be placed on an ordinal scale from 0 to 10. The implication is that a table scoring a " 7 " presents more "liberal" information than a table scoring a "5."

A second approach to the TDTSI is to measure the left-leaning and right-leaning score separately using the formula below. In this case,

Preference $_{\mathrm{L}}=$ Preference $_{\mathrm{L}} /$ Preference $_{\text {Total}}$; and Preference ${ }_{\mathrm{R}}=$ Preference $_{\mathrm{R}} /$ Preference $_{\text {Total }}$.

Where Preference ${ }_{\mathrm{L}}$ is defined as the total number of questions coded as having liberal characteristics, Preference $\mathrm{R}$ is defined as the total number of questions coded as having conservative characteristics and Preference Total is the combination of the two.

This second method provides percentage scores for both "liberal" and "conservative" characteristics. A table with a score of "7" using the first method would have a score of 70\% liberal and 30\% conservative. The benefits of this second method are similar to the first, with the additional benefit of showing scores for both liberal and conservative characteristics. 
However, users of this second method may tend to mistakenly perceive that this method results in an interval scale where a score of $60 \%$ liberal would be twice as liberal as a table with a score of $30 \%$ liberal. Again, the scale is not intended to be an interval scale, but rather an ordinal scale where 10 is more than 1 but not necessarily ten times more.

A third TDTSI scoring measure would subtract the number of left-leaning characteristics from the number of right-leaning characteristics, and divide the result by the total number of questions used in the coding scheme. For example:

$$
\text { Preference }_{\mathrm{LR}}=\left(\text { Preference }_{\mathrm{L}}-\text { Preference }_{\mathrm{R}}\right) / \text { Preference }_{\text {Total }}
$$

Structured in this manner, a score closer to 1 would be fully "liberal" and a score of "- 1 " fully "conservative." The ordering of Preference ${ }_{L}$ and Preference ${ }_{R}$ could be reversed to make a score of 1 fully conservative. A possible benefit of using this third method is that zero becomes a middle point, suggesting that a table with a score of " 0 " is politically balanced, or at least the distribution table is not designed to bias toward a given tax policy perspectives. Again, the scale is not intended to be an interval scale, but rather an ordinal scale.

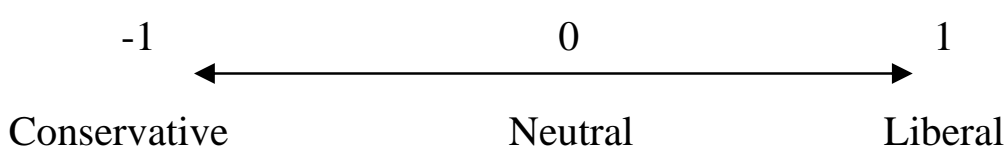

The questions for the Tax Distribution Table Scoring Index are currently structured so as to provide a binary response. In some manner or another, the questions provided below relate to at least one of the elements or categories listed in the literature. Further, the questions in the index also deal with the design of tax distribution tables and the methodological approach applied.

1. Is a measure of income used other than cash income or Adjusted Gross Income (AGI)?

2. Is the unit of analysis families or households?

3. Is the percent change in after-tax income included in the analysis?

4. Is the percent of total tax change included in the analysis?

5. Are payroll taxes included in the analysis of taxes paid?

6. Is the numbers of taxpayers residing within the income categories omitted?

7. Are ranges of income associated with each income category omitted?

8. Are ranges of tax liability associated with each income category omitted?

9. Are the current and proposed percent of total taxes paid for each income category omitted?

10. Are the current and proposed tax rates for each income category omitted?

In Chapter 5, the discussion presented two corresponding tables prepared by the OTA under different presidential administrations and of two different political parties. The discussion illustrates how the different presentations of data result in the portrayal of alternative perspectives, further illustrating how the design and presentation of data can bias and mislead.

However, informative discussions are not presented when tax distribution tables are released to the public or printed in major news media. Therefore, a tool is needed to reveal the different perspectives presented in tax distribution tables. To demonstrate the usefulness of the TDTSI, the TDTSI is applied to both tables from Chapter 5 to reveal the perspectives that were discussed 
in the corresponding text. Tables 5-1 and 5-2 are replicated below as Tables 6-1 and 6-2, respectively.

Clinton Administration Office of Tax Analysis, Department of the Treasury: Table 6-1. Major Provisions Passed by the House Ways and Means Committee ${ }^{1}$

(2000 Income Levels) Very Preliminary

\begin{tabular}{|c|c|c|c|c|c|c|}
\hline \multirow[b]{2}{*}{ Family Economic Income ${ }^{2}$} & \multirow[b]{2}{*}{$\begin{array}{l}\text { Number of } \\
\text { Families } \\
\text { (millions) }\end{array}$} & \multirow[b]{2}{*}{$\begin{array}{c}\text { Average Tax } \\
\text { Change (\$) }\end{array}$} & \multicolumn{2}{|c|}{ Total Tax Change } & \multicolumn{2}{|c|}{ Percent Change In: } \\
\hline & & & $\begin{array}{c}\text { Amount } \\
\text { (millions) }^{3}\end{array}$ & $\begin{array}{c}\text { Percent } \\
\text { Distribution (\%) }\end{array}$ & $\begin{array}{c}\text { Current Federal } \\
\text { Taxes }^{4}\end{array}$ & $\begin{array}{l}\text { After-Tax } \\
\text { Income }{ }^{5} \\
(\%)\end{array}$ \\
\hline Lowest $^{6}$ & 22.4 & -13 & -286 & $0.4 \%$ & $-2.1 \%$ & $0.1 \%$ \\
\hline Second & 23.0 & -77 & $-1,762$ & $2.7 \%$ & $-2.5 \%$ & $0.3 \%$ \\
\hline Third & 23.0 & -192 & $-4,426$ & $6.8 \%$ & $-2.4 \%$ & $0.6 \%$ \\
\hline Fourth & 23.0 & -380 & $-8,748$ & $13.4 \%$ & $-2.4 \%$ & $0.6 \%$ \\
\hline Highest & 23.0 & $-2,164$ & $-49,877$ & $76.6 \%$ & $-4.2 \%$ & $1.4 \%$ \\
\hline Total $^{6}$ & 115.2 & -566 & $-65,131$ & $100.0 \%$ & $-3.6 \%$ & $1.0 \%$ \\
\hline Top 10\% & 11.5 & $-3,442$ & $-39,586$ & $60.9 \%$ & $-4.5 \%$ & $1.6 \%$ \\
\hline Top 5\% & 5.8 & $-5,632$ & $-32,490$ & $49.9 \%$ & $-4.9 \%$ & $1.8 \%$ \\
\hline Тор 1\% & 1.2 & $-17,074$ & $-19,840$ & $30.5 \%$ & $-5.5 \%$ & $2.2 \%$ \\
\hline
\end{tabular}

Source: Department of the Treasury. Office of Tax Analysis. July 17, 2000.

(7) This table distributes the estimated change in tax burdens due to the following major provisions passed by the House Ways and Means Committee in H.R. 7, H.R. 8, H.R. 2990, H.R. 3832, H.R. 3916, H.R. 4810 and H.R. 4843.

(8) Family Economic Income (FEI) is a broad-based income concept. FEI is constructed by adding to AGI unreported and under-reported income; IRA and Keogh deductions; nontaxable transfer payments such as Social Security and AFDC; employer-provided fringe benefits; inside build-up on pensions; IRAs, Keoghs, and life insurance; tax-exempt interest; and imputed rent on owner-occupied housing. Capital gains are computed on an accrual basis, adjusted for inflation to the extent that reliable data allow. Inflationary losses of lenders are subtracted and gains of borrowers are added. There is also an adjustment for accelerated depreciation of noncorporate businesses. FEI is shown on a family rather than a tax-return basis. The economic incomes of all members of a family unit are added to arrive at the family's economic income used in the distributions.

(9) The change in Federal taxes is estimated at 2000 income levels assuming fully phased in law. Current and proposed taxes are estimated using FY2000 Budget assumptions. The tax benefit of the increase in retirement contribution limits is measured as the present value of tax savings on one year's contributions.

(10) The taxes included are individual and corporate income, payroll, excises, customs duties, and estate and gift taxes. The individual income tax is assumed to be borne by payers, the corporate income tax by capital generally, payroll taxes (employer and employee shares) by labor (wages and self-employment income), excises on purchases by individuals in proportion to relative consumption of the taxed good and proportionately by labor and capital and excises on purchases by businesses and customs duties proportionately to labor and capital, and the estate tax by decedents. Federal taxes are estimated at 2000 income levels but assuming 2009 law and, therefore, exclude provisions that expire prior to the end of the Budget period and are adjusted for the effects of unindexed parameters.

(11) After-tax income is Family Economic Income less current Federal taxes.

(12) Families with negative incomes are excluded from the lowest quintile but included in the total line.

NOTE: Quintiles begin at FEI of: Second \$17,988; Third \$34,844; Fourth \$59,019; Highest \$100,767; Top 10\% \$140,581; Top 5\% \$189,835; Top 1\% \$462,053.

\begin{tabular}{|c|c|c|c|}
\hline $\begin{array}{l}\text { Tax Distribution Table Scoring Index (TDTSI) Analysis Tool for Revealing } \\
\text { Methodology, Content and Presentation in Tax Distribution Tables }\end{array}$ & $\begin{array}{c}\text { Yes - } \\
\text { Score } \\
\text { as “1" }\end{array}$ & $\begin{array}{c}\text { No - } \\
\text { Score } \\
\text { as “0” }\end{array}$ & $\begin{array}{l}\text { Can Not Be } \\
\text { Determined }\end{array}$ \\
\hline $\begin{array}{l}\text { 1. Is a measure of income used other than cash income or Adjusted Gross } \\
\text { Income (AGI)? }\end{array}$ & 1 & & \\
\hline 2. Is the unit of analysis families or households? & 1 & & \\
\hline 3. Is the percent change in after-tax income included in the analysis? & 1 & & \\
\hline 4. Is the percent of total tax change included in the analysis? & 1 & & \\
\hline 5. Are payroll taxes included in the analysis of taxes paid? & 1 & & \\
\hline 6. Is the number of taxpayers residing within the income categories omitted? & & 0 & \\
\hline 7. Are ranges of income associated with each income category omitted? & & 0 & \\
\hline 8. Are ranges of tax liability associated with each income category omitted? & 1 & & \\
\hline $\begin{array}{l}\text { 9. Are the current and proposed percent of total taxes paid for each income } \\
\text { category omitted? }\end{array}$ & 1 & & \\
\hline 10. Are the current and proposed tax rates for each income category omitted? & 1 & & \\
\hline
\end{tabular}

Table 6-1 was prepared by the OTA under the Clinton/Gore Administration and during the presidential campaign of 2000. Applying the Tax Distribution Table Scoring Index to the analysis of this table would provide affirmative responses for the following questions: $1,2,3,4$, 
5, 8, 9, and 10. For Question \#7 (income ranges), the dollar cut-off points are provided for the quintiles in the notes.

Therefore, using the first method of simply summing the responses, the 2000 OTA table exhibits liberal characteristics in 8 out of 10 questions, or $80 \%$. The second approach yields a result that indicates the table has left-leaning characteristics $9 / 10$ or $0.90(90 \%)$ and right-leaning characteristics $2 / 10$ or $0.20(20 \%)$, showing a definite left-leaning tilt. The third approach results in a score that is left-leaning $0.60[(8-2) / 10]$.

Again, applying all three measures provides similar results. Using the TDTSI to evaluate the Clinton OTA tax distribution table, the methodologies and presentations of data used in Table 61 portray the results of an analysis to a change in tax law in a manner that is liberal-leaning. But how is this useful to the public?

As discussed, liberal-leaning policies are more likely to favor redistribution of wealth and/or after-tax income while conservatives are more likely to favor consumption taxes over income taxes and be concerned with the share of taxes paid by different groups and who bears the burden of paying for government. The TDTSI has revealed that the perspectives presented in 2000 OTA table are favorable to redistribution of income and opposed to general tax relief.

The perspective presented in the 2000 OTA table suggests that the tax plan in question would be regressive and overly benefit the rich by including "average tax change," which shows the lowest income group receiving $\$ 13$ in tax cuts and the top quintile receiving $\$ 2,164$. The perspective that the tax plan in question would be regressive and overly benefit the rich is further supported by including variable relating to "total tax change" and "percent change in after-tax income," both of which portray that the higher income quintiles receive more benefit than lower income quintiles.

Applying the TDTSI to the table provides a score that indicates liberal-leaning perspectives are being advanced that support redistribution of income and ignoring conservative perspectives, which are more concerned with which groups are paying for government. Applying the TDTSI, readers of the 2000 OTA table can realize that the table is not presented in a balanced manner. For example, the current and proposed percent of total taxes paid (tax shares) is omitted, which if including might present a more balanced perspective. If desired, readers of the 2000 OTA table could request that, in order to gain a balanced perspective, the table be re-released with the missing variables included. 
Bush Administration Office of Tax Analysis, Department of the Treasury: Table 6-2. Major Individual Income Tax Provisions of the President's Tax Proposal ${ }^{1}$ (2000 Income Levels)

\begin{tabular}{|c|c|c|c|c|c|}
\hline \multirow[b]{2}{*}{ Cash Income Class $^{2}$} & \multirow{2}{*}{$\begin{array}{c}\text { Distribution of } \\
\text { Proposed } \\
\text { Changes in } \\
\text { Individual } \\
\text { Income Taxes } \\
(\%) \\
\end{array}$} & \multicolumn{2}{|c|}{$\begin{array}{c}\text { Distribution of Total Individual } \\
\text { Income Taxes }{ }^{3}\end{array}$} & \multirow{2}{*}{$\begin{array}{c}\text { Average Individual } \\
\text { Income Taxes With } \\
\text { Proposed Changes } \\
\text { (\$) }\end{array}$} & \multirow{2}{*}{$\begin{array}{l}\text { Percent Change in } \\
\text { Individual Income } \\
\text { Taxes } \\
(\%)\end{array}$} \\
\hline & & $\begin{array}{c}\text { Current Law } \\
(\%)\end{array}$ & $\begin{array}{c}\text { With Proposed } \\
\text { Changes }{ }^{4} \\
(\%)\end{array}$ & & \\
\hline $0-30$ & 9.3 & -1.0 & -2.8 & -457 & -136.2 \\
\hline $30-40$ & 6.5 & 2.5 & 1.8 & 993 & -38.3 \\
\hline $40-50$ & 7.8 & 4.1 & 3.4 & 2,210 & -28.0 \\
\hline $50-75$ & 17.2 & 12.2 & 11.3 & 4,279 & -20.8 \\
\hline $75-100$ & 13.6 & 12.2 & 12.0 & 7,848 & -16.3 \\
\hline $100-200$ & 19.8 & 27.1 & 28.3 & 16,625 & -10.7 \\
\hline $200 \&$ Over & 25.4 & 42.9 & 45.9 & 103,931 & -8.7 \\
\hline Total $^{5}$ & 100.0 & 100.0 & 100.0 & 6,322 & -14.6 \\
\hline
\end{tabular}

Source: Department of the Treasury. Office of Tax Analysis. March 8, 2001.

(6) The major individual income tax provisions are: i) lower individual income tax rates; ii) increase the child credit to $\$ 1,000$, raise the income level at which it phases out, and allow the child credit against the AMT; iii) allow a 10\% deduction for the earnings of the lower earning spouse (up to \$30,000) in two-earner families; iv) allow taxpayers who do not itemize to deduct charitable contributions up to the amount of the taxpayer's standard deduction; and v) provide a refundable tax credit for individually-purchased health insurance.

(7) Cash Income consists of wages and salaries, net income from a business or farm, taxable and tax-exempt interest, dividends, rental income, realized capital gains, cash transfers from the government, and retirement benefits. Employer contributions for payroll taxes and the federal corporate income tax are added to place cash on a pre-tax basis. Cash income is shown on a family rather than on a tax return basis. The cash incomes of all members of a family are added to arrive at a family's cash income used in the distributions.

(8) The refundable portions of the earned income tax credit (EITC) and the child credit are included in the individual income tax. Federal taxes are estimated at 2000 income levels but assuming fully phased in law and, therefore, exclude provisions that expire prior to the end of the Budget period and are adjusted for the effects of unindexed parameters.

(9) The change in Federal taxes is estimated at 2000 income levels assuming fully phased in law.

(10) Families with negative incomes are excluded from the lowest income class but included in the total line.

\begin{tabular}{|c|c|c|c|}
\hline $\begin{array}{l}\text { Tax Distribution Table Scoring Index (TDTSI) Analysis Tool for Revealing } \\
\text { Methodology, Content and Presentation in Tax Distribution Tables }\end{array}$ & $\begin{array}{l}\text { Yes- } \\
\text { Score } \\
\text { as "1" }\end{array}$ & $\begin{array}{l}\text { No- } \\
\text { Score } \\
\text { as “0" }\end{array}$ & $\begin{array}{l}\text { Can Not Be } \\
\text { Determined }\end{array}$ \\
\hline $\begin{array}{l}\text { 1. Is a measure of income used other than cash income or Adjusted Gross } \\
\text { Income (AGI)? }\end{array}$ & & 0 & \\
\hline 2. Is the unit of analysis families or households? & 1 & & \\
\hline 3. Is the percent change in after-tax income included in the analysis? & & 0 & \\
\hline 4. Is the percent of total tax change included in the analysis? & 1 & & \\
\hline 5. Are payroll taxes included in the analysis of taxes paid? & & 0 & \\
\hline 6. Is the number of taxpayers residing within the income categories omitted? & 1 & & \\
\hline 7. Are ranges of income associated with each income category omitted? & & 0 & \\
\hline 8. Are ranges of tax liability associated with each income category omitted? & 1 & & \\
\hline $\begin{array}{l}\text { 9. Are the current and proposed percent of total taxes paid for each income } \\
\text { category omitted? }\end{array}$ & & 0 & \\
\hline 10. Are the current and proposed tax rates for each income category omitted? & 1 & & \\
\hline
\end{tabular}

The table produced by the OTA in 2001 under the Bush Administration takes a markedly different approach from the table produced by the 2000 OTA. Applying the Tax Distribution Table Scoring Index to the analysis of this table would provide affirmative responses for the following questions: 2, 4, 6, 8, and 10. Note that although employer contributions for payroll taxes are added to cash income to place cash on a pre-tax basis (footnote \#2 and relating to taxonomy question \#5), payroll taxes are not included in the analysis of taxes paid. 
Applying the first method of analysis to Table 6-2, simply summing the responses, indicates that the 2001 OTA table exhibits liberal characteristics in 5 out of 10 questions. However, it is hard to argue that the 2001 table, with a score of 5 , is even close to being neutral just because some measures are omitted. The second approach yields a similar result: the table has left-leaning characteristics $5 / 10$ or $0.50(50 \%)$ and right-leaning characteristics $5 / 10$ or $0.50(50 \%)$, again indicating a balanced perspective. The third approach also results in a score that is balanced: zero [(5 - 5) / 10]. Since this value is zero, the results of the third method support the contention that the table is not designed to advance tax policy positions associated with liberal tax policy perspectives, or advance conservative tax policy perspectives.

The 2001 OTA table presents a different perspective than the table OTA released in 2000. The 2001 table is designed to promote tax legislation that provides tax relief and portrays the legislation in question as one that increases progressivity in the tax code. The perspective presented in the 2001 OTA table suggests that the tax plan in question would be progressive by presenting data on the "percent change in individual income taxes", which show lower-income groups getting a better percentage change than upper-income groups. However, just because the TDTSI indicates the 2001 OTA table balances liberal and conservative perspectives, is the table actually balanced?

Regarding the 2001 OTA table, a former Clinton administration Treasury Deputy Assistant Secretary for Tax Analysis Len Burman writes "the presentation of the data and exclusion of certain information but the president's proposal in the best possible light and create a misleading impression of the distribution of benefits from the proposed tax cuts." ${ }^{115}$ Similar arguments were also made about misleading presentations of data when Burman was the official at Treasury responsible for overseeing distribution analysis. ${ }^{116}$

However, applying the TDTSI, readers of the 2001 OTA table would realize that the table is presented without five measures that are assumed to present a liberal perspective. If desired, readers of the 2001 OTA table could request that in order to gain additional perspectives, the table be re-released with the missing variables included. Hence, even if the TDTSI might indicate a table balances perspectives when some might consider it does not, the utility of the TDTSI is still evident as it allows users to identify missing variables that can have an impact on perspectives.

The application of the TDTSI in this chapter has demonstrated how the TDTSI can be used to reveal the perspectives advanced by different tax distribution tables and provide a useful tool to balance these perspectives. Regardless of one's political viewpoints and irrespective of whether or not one is a supporter of policies that redistribute income or not, the TDTSI can be used by all persons to reveal the perspectives presented in tax distribution tables and balance any biased or misleading presentations of data. Unless there is greater public recognition of both the art and

\footnotetext{
${ }^{115}$ Len Burman, “Treasury’s New Distribution Presentation,” Tax Notes (March 26, 2001.

116 See, for example: Jason Fichtner, “A Guide to Tax Policy Analysis: Problems with Distributional Tax Tables,” U.S. Congress, Joint Economic Committee (January 2000); “A Guide to Tax Policy Analysis: The Central Tendency of Federal Income Tax Liabilities in Distributional Analysis,” U.S. Congress, Joint Economic Committee (May 2000); “The Misleading Effects of Averages in Tax Distribution Analysis,” U.S. Congress, Joint Economic Committee (September 2003); and "A Comparison of Tax Distribution Tables: How Missing or Incomplete Information Distorts Perspectives,” U.S. Congress, Joint Economic Committee (December 2003).
} 
the science of distributional analysis, tax policy will be unduly influenced by misleading tax distribution tables.

The TDTSI can promote a more transparent dissemination of data and an insightful understanding of tax distribution tables so policymakers and the general public can make informed decisions about the merits of proposed tax legislation. Given that it is highly unlikely that the use of distribution tables will be abandoned, the best recommendation is that the public should demand full disclosure of any and all relevant data. Full disclosure includes, at the very least, using income measures that are understood by the public (like cash income or adjusted gross income), providing median values as well as averages, fully describing any imputations, conducting sensitivity analyses, disclosing measures of variance, and fully explaining the limitations of the data and subsequent distribution tables. The TDTSI provides the necessary policy evaluation tool to allow policymakers and the public to effectively balance the different perspectives presented by opposing tax distribution tables and to request more balanced tax distribution tables in the future. 
Jason J. Fichtner

\section{CHAPTER 7 - AN APPLiCATION OF THE TAX DistribUtion TABLE SCORING INDEX (TDTSI) TO SPECIFIC TAX LEGISLATION}

Having demonstrated the application of the TDTSI in Chapter 6, Chapter 7 now provides an expanded application of the TDTSI by analyzing tax distribution tables related to the five main individual income tax bills from 1993 through 2004. The first four of these bills are identified as major tax bills signed into law by Tempalski (2003), an economist with the Treasury Department, Office of Tax Analysis. These bills are: (1) Omnibus Budget Reconciliation Act of 1993; (2) Taxpayer Relief Act of 1997; (3) Economic Growth and Tax Relief Reconciliation Act of 2001; and (4) Jobs and Growth Tax Relief and Reconciliation Act of 2003. A fifth (5) bill (Working Families Tax Relief Act of 2004) was recently passed by the Congress in September 2004. ${ }^{117}$ A description of the provisions included in these bills is also provided.

Distribution analyses are occasionally conducted not only on specific tax bills, but on the current distribution of tax burden. The Joint Committee on Taxation, Congressional Budget Office and the Tax Policy Center perform such analyses. As a sixth (6) application of the TDTSI, this chapter will also compare some of these distribution tables for the time period under analysis.

The analysis presented in this chapter is not intended to be an exhaustive census of every tax distribution table prepared between 1993 and 2004 or include every major news article discussing the proposed tax distribution of the specific bills. On the contrary, the following analysis is intended to provide a representation of the tax distribution tables that were presented by government agencies and advocacy groups, and to demonstrate the utility of the TDTSI as a tool of policy analysis for evaluating tax distribution tables and balancing perspectives.

Most of the distribution tables in this chapter are publicly available either on the websites of the issuing organizations or from newspaper articles and books. Some tables were released to the author by third parties upon request. A list of each distribution table used in this chapter is available in the appendix. Every attempt is made to replicate tax distribution tables in this chapter exactly as they were presented in an official publication, memo, fax newspaper article, book chapter, etc., so that the presentations of data and perspectives presented are preserved. Accounts of the policy debates surrounding the various tax bills, as reported in major news sources, are provided to give a plausible overview of the context of the various policy perspectives at the time.

\section{Omnibus Budget Reconciliation Act of 1993 (OBRA 93)}

The Omnibus Budget Reconciliation Act of 1993 was passed in August 1993 during the presidency of Democrat Bill Clinton and at a time when the Democrats were in the majority of both the House of Representatives and the Senate. The bill was touted by President Clinton as part of his plan to reduce the federal budget deficit. The bill passed the Congress by the narrowest of margins. In the House, the bill was passed August 5, 1993 by a 218-216 vote (a

\footnotetext{
${ }^{117}$ Legislation to extend the provisions of EGTRRA 2001 \& JGTRRA 2003 was passed in September 2004, as the Working Families Tax Relief Act of 2004. Distribution tables were not publicly released for this piece of legislation by OTA or JCT, though some tables were prepared by interest groups.
} 
shift of one vote would have resulted in the bill failing to pass on a tie vote). In the Senate, then Vice President Al Gore cast the tie-breaking vote the next evening and the bill passed 51-50. No Republican legislator voted for the bill.

The main tax provisions of OBRA 93:

- $\quad$ created a 36\% and 39.6\% marginal tax bracket for individuals;

- repealed the wage income cap on Medicare taxes;

- increased transportation fuel taxes by 4.3 cents per gallon;

- increased the taxable portion of Social Security benefits;

- permanently extended phase-out of personal exemption and limit on itemized deductions; and

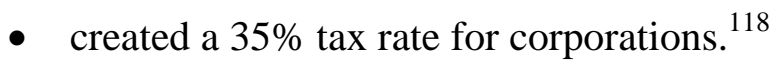

A USA Today article describes the perspectives being advanced by both liberals and conservatives leading up to the congressional vote:

The wealthy are watching their wallets. Small business owners are protecting their payrolls. Seniors are securing their Social Security benefits. Their focus: the "Omnibus Budget Reconciliation Act of 1993," a tome-like document implementing the bulk of President Clinton’s five-year, \$500 billion deficit reduction program.

But in Washington parlance, it's a tax bill. And as always, the focus is on who will pay the tab: Democrats' answer: rich people. Under the plan now on the Senate floor, $79 \%$ of the $\$ 249$ billion in higher taxes would be paid by those earning above $\$ 200,000$. Republicans' answer: the middle class, the elderly, small business, family farmers. Imposing the largest tax increase in history, they argue, will suck jobs and investment out of the economy, hurting everyone. ${ }^{119}$

Another USA Today article reports:

Taxing the rich is apparently back in style. After spending much of the 1980s slashing tax rates for the wealthy, Congress appears on the verge of reversing course. The budget deal, which must be approved by the House and Senate, would extract $\$ 241.2$ billion from taxpayers over five years. But $81 \%$ of that about $\$ 195$ billion - would be paid by families making more than $\$ 200,000$ a year.

Most middle-class families hardly would be nicked. They'll pay the lion's share of a 4.3-cents increase in the federal gasoline tax. But the increase would cost the average family less than $\$ 5$ a month. "It’s trivial," says Robert McIntyre of

\footnotetext{
118 Jerry Tempalski, “Revenue Effects of Major Tax Bills,” U.S. Department of the Treasury, Office of Tax Analysis, OTA Paper 81 (Revised July 2003).

${ }^{119}$ Richard Wolf, “Parties Class on Who’ll Pay Budget Bill Tab,” USA Today, June 24, 1993.
} 
Citizens for Tax Justice, a group that favors higher taxes on the wealthy and big corporations. $^{120}$

Conservatives attacked the bill by portraying it as a major increase in taxes on the middle-class, primarily as a result of the increase in the gas tax, which would harm economic growth. ${ }^{121}$ Conservatives also criticized some of the proposed spending cuts in the bill arguing that they were actually hidden tax increases and even made a point of noting the party in control of the Congressional Joint Committee on Taxation, as Dan Mitchell of the Heritage Foundation wrote in a commentary published in The Washington Times:

The House of Representatives last week narrowly approved President Clinton's budget reconciliation bill, a measure which purports to reduce future federal budget deficits by a total of $\$ 336.8$ billion over the next five years. The Clinton administration and the House Democratic leadership claim that the legislation represents a balanced use of spending cuts and tax increases to reduce federal borrowing. More than $\$ 301$ billion, or 89.5 percent of the total, comes from increased revenue. The legislation would impose the largest tax increase in American history...

Architects of the House "deficit reduction" bill have attempted to hide the size of the tax increase. But the claim that legislation raises “just” \$246 billion over the next five years is accomplished only by using creative accounting to portray some spending increases as tax "cuts" and to characterize many revenue increases as "spending cuts."

The Democrat-controlled Joint Committee on Taxation, for instance, admits that three provisions that are counted as tax "cuts" are really spending increases. ${ }^{122}$

Generally, liberals supported OBRA 93 as a tax increase on the wealthy to reduce the federal budget deficit, while conservatives argued that the tax increases in the bill would harm economic growth and burden the middle-class. But what perspectives were presented in the tax distribution tables relating to OBRA 93? The following four tables provide examples of tables released by the Congressional Joint Committee on Taxation, the Treasury's Office of Tax Analysis under the Clinton Administration, the Congressional Budget Office, and Citizens for Tax Justice, a laborbacked interest group.

\footnotetext{
${ }^{120}$ Bill Montague, "Rich to Pick up the Tab,” USA Today, August 4, 1993.

${ }^{121}$ Richard Wolf, “Parties Class on Who’ll Pay Budget Bill Tab,” USA Today, June 24, 1993.

122 Dan Mitchell, “Making a Bad Budget Even Worse,” Commentary, The Washington Times, June 2, 1993.
} 


\section{Table 7-1. Joint Committee on Taxation}

\begin{tabular}{|c|c|c|c|c|}
\hline \multicolumn{5}{|c|}{$\begin{array}{c}\text { Table 7-1. Distributional Effects of the Revenue Provisions C } \\
1993 \text { OBRA as Agreed to by the Conferees } \\
\text { (1993 income levels) }\end{array}$} \\
\hline $\begin{array}{c}\text { Expanded Income } \\
\text { Class }^{a}\end{array}$ & $\begin{array}{l}\text { Present- } \\
\text { Law } \\
\text { Federal } \\
\text { Taxes }^{b} \\
\text { (billions } \\
\text { of \$) }\end{array}$ & $\begin{array}{c}\text { Present- } \\
\text { Law } \\
\text { Average } \\
\text { Tax Rate } \\
\text { (\%) }\end{array}$ & $\begin{array}{c}\text { Proposed } \\
\text { Change in } \\
\text { Tax } \\
\text { Burden }^{d} \\
\text { (millions } \\
\text { of \$) }\end{array}$ & $\begin{array}{c}\text { Burden } \\
\text { Change } \\
\text { as Share } \\
\text { of } \\
\text { Income } \\
(\%)\end{array}$ \\
\hline Less than $\$ 10,000$ & 9 & 10.4 & $-1,152$ & -1.28 \\
\hline $10,000-20,000$ & 39 & 11.9 & -993 & -0.30 \\
\hline $20,000-30,000$ & 72 & 17.0 & 94 & 0.02 \\
\hline $30,000-40,000$ & 86 & 19.1 & 949 & 0.21 \\
\hline $40,000-50,000$ & 93 & 20.9 & 1,271 & 0.29 \\
\hline $50,000-75,000$ & 201 & 22.3 & 3,517 & 0.39 \\
\hline $75,000-100,000$ & 120 & 24.6 & 2,653 & 0.54 \\
\hline $100,000-200,000$ & 142 & 26.6 & 4,598 & 0.86 \\
\hline $\begin{array}{c}200,000 \text { and over } \\
\text { Total, all }\end{array}$ & 168 & 30.2 & 29,863 & 5.39 \\
\hline taxpayers & 930 & 22.1 & 40,800 & 0.97 \\
\hline
\end{tabular}

a. The income concept used to place tax returns into income categories is adjusted gross income plus: (1) tax-exempt interest; (2) employer contributions for health plans and life insurance; (3) employer share of FICA tax; (4) workers' compensation; (5) nontaxable social security benefits; (6) insurance value of Medicare benefits; (7) corporate income tax liability attributed to stockholders; (8) alterative minimum tax preference items; and (9) excluded income of U.S. citizens living abroad.

b. Includes individual income tax, FICA and Self Employment Contributions Act taxes, excise taxes, estate and gift taxes, and corporate income tax.

c. Present-law federal taxes as a share of expanded income.

d. Includes all revenue provisions except: Individual and corporate estimated tax changes, information reporting for discharge of indebtedness, targeted jobs credit, capital gains incentives, provisions affecting qualified pension plans, mortgage revenue bonds, low-income housing credit, luxury tax provisions, excise tax on diesel fuel used in noncommercial motorboats, empowerment zones and enterprise communities, vaccine excise tax, Generalized System of Preferences (a tariff item) and Federal Unemployment Tax Act extensions, transfer of Federal Reserve funds, deduction disallowance for certain health plan, orphan drug credit, and diesel fuel compliance.

Source: Joint Committee on Taxation, August 3, 1993. - As reprinted by Barthold, Nunns, and Toder in Bradford (Editor) (1995), page 102. 


\begin{tabular}{|c|c|c|c|}
\hline $\begin{array}{l}\text { Tax Distribution Table Scoring Index (TDTSI) Analysis Tool for Revealing } \\
\text { Methodology, Content and Presentation in Tax Distribution Tables }\end{array}$ & $\begin{array}{l}\text { Yes - } \\
\text { Score } \\
\text { as “1" }\end{array}$ & $\begin{array}{l}\text { No- } \\
\text { Score } \\
\text { as “0" }\end{array}$ & $\begin{array}{l}\text { Can Not Be } \\
\text { Determined }\end{array}$ \\
\hline $\begin{array}{l}\text { 1. Is a measure of income used other than cash income or Adjusted Gross } \\
\text { Income (AGI)? }\end{array}$ & & 0 & \\
\hline 2. Is the unit of analysis families or households? & & 0 & \\
\hline 3. Is the percent change in after-tax income included in the analysis? & & 0 & \\
\hline 4. Is the percent of total tax change included in the analysis? & & 0 & \\
\hline 5. Are payroll taxes included in the analysis of taxes paid? & 1 & & \\
\hline 6. Is the number of taxpayers residing within the income categories omitted? & 1 & & \\
\hline 7. Are ranges of income associated with each income category omitted? & & 0 & \\
\hline 8. Are ranges of tax liability associated with each income category omitted? & 1 & & \\
\hline $\begin{array}{l}\text { 9. Are the current and proposed percent of total taxes paid for each income } \\
\text { category omitted? }\end{array}$ & 1 & & \\
\hline 10. Are the current and proposed tax rates for each income category omitted? & 1 & & \\
\hline
\end{tabular}

Applying the three scoring methods of the TDTSI to the JCT table give the following results. Using the first method of simply summing the responses, the JCT table exhibits liberal characteristics in 5 out of 10 questions, or $50 \%$. The second approach yields a result that indicates the table balances liberal and conservative perspectives $5 / 10$ or $0.50(50 \%)$ and rightleaning characteristics $5 / 10$ or 0.50 (50\%). The third approach also results in a score that is balanced at zero $[(5-5) / 10]$.

Interestingly, the JCT table presents the current tax rates for each income groups but omits the proposed tax rates that would result from changing tax law (TDTSI Question \#10). Had JCT included this measure, the table would have had one less liberal point and an overall score that was slightly balanced toward the conservative perspective.

Though the Joint Committee on Taxation was under the control of the Democratic majority in both the House and Senate, the JCT table presented in this chapter balances the perspectives of both liberals and conservatives. For example, while the JCT table does include payroll taxes and corporate income taxes (which it does not do presently), the JCT table does not use a broadbased imputed income concept, nor provide the average tax cut, nor present information on the percent change in after-tax income.

The JCT table does support the contention made by Democrats that the provisions in OBRA 93 were progressive in nature and put most of the burden on those making over $\$ 200,000$. Further, taxpayers having incomes less $\$ 20,000$ are shown to be receiving a tax cut. The JCT table also supports the Republican perspective that the tax cuts where going to burden the middle-class, but not to the extent the burden would be borne by the highest income groups. 


\section{Table 7-2. Office of Tax Analysis}

\begin{tabular}{|c|c|c|c|c|c|c|c|c|c|}
\hline able 7-2. Di & tor tile & Security & $\begin{array}{l}\text { nefits and Ex } \\
(199\end{array}$ & $\begin{array}{l}\text { sion of } \\
\text { ome lev }\end{array}$ & C and & tamp & & & \\
\hline & Federal Tax & xes under & Current Law ${ }^{b}$ & Change & in Federal & $\operatorname{Taxes}^{c}$ & Total Feder & ral Taxes af & er Change \\
\hline $\begin{array}{c}\text { Family Economic } \\
\text { Income Class }{ }^{a} \\
\text { (thousands of dollars) }\end{array}$ & $\begin{array}{l}\text { Amount } \\
\text { (billions } \\
\text { of } \$ \text { ) }\end{array}$ & $\begin{array}{c}\text { As a } \\
\text { percent } \\
\text { of pretax } \\
\text { income }\end{array}$ & $\begin{array}{c}\text { As a } \\
\text { percent } \\
\text { of after-tax } \\
\text { income (\%) }\end{array}$ & $\begin{array}{l}\text { Amount } \\
\text { (billions of } \\
\$ \text { ) }\end{array}$ & $\begin{array}{c}\text { As a } \\
\text { percent of } \\
\text { pretax } \\
\text { income }\end{array}$ & $\begin{array}{c}\text { As a } \\
\text { percent } \\
\text { of after- } \\
\text { tax } \\
\text { income } \\
(\%)\end{array}$ & $\begin{array}{l}\text { Amount } \\
\text { (billions of } \\
\$ \text { ) }\end{array}$ & $\begin{array}{c}\text { As a } \\
\text { percent of } \\
\text { pretax } \\
\text { income }\end{array}$ & $\begin{array}{c}\text { As a } \\
\text { percent } \\
\text { of after- } \\
\text { tax } \\
\text { income } \\
(\%)\end{array}$ \\
\hline $0-10$ & 6.7 & 7.8 & 8.5 & -0.5 & -0.6 & -0.6 & 6.2 & 7.2 & 7.9 \\
\hline $10-20$ & 26.9 & 9.8 & 10.9 & -1.4 & -0.5 & -0.6 & 25.5 & 9.3 & 10.3 \\
\hline $20-30$ & 55.7 & 14.0 & 16.3 & 0.1 & -0.2 & -0.2 & 54.9 & 13.8 & 16.1 \\
\hline $30-50$ & 152.1 & 17.3 & 20.9 & 1.6 & 0.2 & 0.2 & 153.7 & 17.4 & 21.1 \\
\hline $50-75$ & 203.1 & 19.0 & 23.5 & 3.2 & 0.3 & 0.4 & 206.3 & 19.3 & 23.8 \\
\hline $75-100$ & 174.3 & 20.4 & 25.6 & 3.0 & 0.4 & 0.4 & 177.4 & 20.7 & 26.0 \\
\hline $100-200$ & 242.6 & 21.2 & 26.8 & 5.3 & 0.5 & 0.6 & 247.9 & 21.6 & 27.4 \\
\hline 200 and over & 247.5 & 20.9 & 26.5 & 23.4 & 2.7 & 3.5 & 279.9 & 23.7 & 30.0 \\
\hline Total $^{d}$ & $1,110.5$ & 19.0 & 23.4 & 42.9 & 0.7 & 0.9 & $1,153.3$ & 19.7 & 24.3 \\
\hline $\begin{array}{l}\text { Note: This table distribu } \\
\text { social security benefits. } \\
\text { a. Family economic inc } \\
\text { ported and underreport } \\
\text { employer-provided fring } \\
\text { puted rent on owner-oc } \\
\text { data allow. Inflationary } \\
\text { depreciation of noncorp } \\
\text { members of a family un } \\
\text { b. The taxes included a } \\
\text { gift taxes and customs } \\
\text { by capital income gene } \\
\text { on purchases by individ } \\
\text { tures. Taxes due to pro } \\
\text { c. The change in federa } \\
\text { All excise and payroll ta } \\
\text { assumptions for tax ch } \\
\text { d. Families with negativ } \\
\text { Source: Department of } \\
\text { page } 101 .\end{array}$ & $\begin{array}{l}\text { the estimat } \\
\text { luded is a t } \\
\text { (FEI) is a b } \\
\text { come; IRA } \\
\text { enefits; insic } \\
\text { ed housing. } \\
\text { es of lende } \\
\text { e businesse } \\
\text { e added to } \\
\text { dividual an } \\
\text { es are exclu } \\
\text { payroll tax } \\
\text { by the purc } \\
\text { ons that exp } \\
\text { kes is estim } \\
\text { fects on ind } \\
\text { s are the sa } \\
\text { comes are i } \\
\text { Treasury, O }\end{array}$ & $\begin{array}{l}\text { ed change } \\
\text { total of } \$ 6 . \\
\text { broad-base } \\
\text { and Keog } \\
\text { de build-up } \\
\text { Capital g } \\
\text { rs are sub } \\
\text { es. FEI is } \\
\text { arrive at th } \\
\text { dd corporat } \\
\text { ded. The } \\
\text { es (emplo } \\
\text { chaser, an } \\
\text { pire before } \\
\text { lated at } 19 \\
\text { dexed trans } \\
\text { ame as for } \\
\text { included in } \\
\text { ffice of Ta }\end{array}$ & $\begin{array}{l}\text { in tax liabilitie } \\
4 \text { billion of exp } \\
\text { ed income con } \\
\text { h deductions; } \\
\text { on pensions, } \\
\text { yains are comp } \\
\text { tracted and of } \\
\text { shown on a fa } \\
\text { e family's eco } \\
\text { e income, pay } \\
\text { individual ince } \\
\text { yer and emplo } \\
\text { d excises on p } \\
\text { the end of the } \\
94 \text { levels but } \\
\text { sfers and tax b } \\
\text { current law to } \\
\text { the total line } \\
\text { ax Analysis. - }\end{array}$ & $\begin{array}{l}\text { ue to the re } \\
\text { sions in the } \\
\text { t. FEl is cc } \\
\text { ntaxable tra } \\
\text { As, Keoghs } \\
\text { ed on an ac } \\
\text { rrowers are } \\
\text { y rather tha } \\
\text { mic income } \\
\text { (social sec } \\
\text { tax is ass } \\
\text { shares) by } \\
\text { chases by b } \\
\text { udget perio } \\
\text { uming fully } \\
\text { kets are ac } \\
\text { s (see footr } \\
\text { not shown } \\
\text { eprinted by }\end{array}$ & $\begin{array}{l}\text { revenue pro } \\
\text { e EITC and } \\
\text { constructed } \\
\text { ansfer paym } \\
\text { Is, and life in } \\
\text { ccrual basis } \\
\text { e added. Tr } \\
\text { lan on a tax } \\
\text { e used in the } \\
\text { curity and ut } \\
\text { sumed to be } \\
\text { y labor (wa } \\
\text { business in } \\
\text { od (that is, b } \\
\text { phased-in } \\
\text { ccounted fo } \\
\text { tnote b). } \\
\text { ר separately. } \\
\text { y Barthold, } 1\end{array}$ & $\begin{array}{l}\text { y adding } \\
\text { ents such } \\
\text { surance; to } \\
\text { adjusted } \\
\text { ere is also } \\
\text { eturn basi } \\
\text { distributio } \\
\text { lemployme } \\
\text { borne by } \\
\text { es and se } \\
\text { oroportion } \\
\text { efore } 1999 \\
\text { 1998) law } \\
\text { All incor }\end{array}$ & $\begin{array}{l}\text { including } \\
\text { ansion of fc } \\
\text { justed gros } \\
\text { ocial securi } \\
\text { empt inter } \\
\text { flations to t } \\
\text { adjustment } \\
\text { he econom } \\
\text { and excise } \\
\text { s, the corp } \\
\text { ployment it } \\
\text { tal consum } \\
\text { excluded. } \\
\text { longOrun (1 } \\
\text { bayroll, and } \\
\text { ler in Bradf }\end{array}$ & $\begin{array}{l}\text { taxation of } \\
\text { ood stamps } \\
\text { s income u } \\
\text { ity and AFD } \\
\text { est; and im- } \\
\text { the extent re } \\
\text { for acceler } \\
\text { ic incomes } \\
\text { s. Estate a } \\
\text { orate incom } \\
\text { ncome), ex } \\
\text { ption expen } \\
\text { 1998) behav } \\
\text { excise tax } \\
\text { ord (Editor) }\end{array}$ & $\begin{array}{l}\text { re- } \\
\text { c; } \\
\text { liable } \\
\text { ted } \\
\text { of all } \\
\text { id } \\
\text { e tax } \\
\text { ises } \\
\text { di- } \\
\text { or. }\end{array}$ \\
\hline
\end{tabular}

\begin{tabular}{|c|c|c|c|}
\hline $\begin{array}{l}\text { Tax Distribution Table Scoring Index (TDTSI) Analysis Tool for Revealing } \\
\text { Methodology, Content and Presentation in Tax Distribution Tables }\end{array}$ & $\begin{array}{l}\text { Yes - } \\
\text { Score } \\
\text { as “1" }\end{array}$ & $\begin{array}{l}\text { No- } \\
\text { Score } \\
\text { as "0" }\end{array}$ & $\begin{array}{l}\text { Can Not Be } \\
\text { Determined }\end{array}$ \\
\hline $\begin{array}{l}\text { 1. Is a measure of income used other than cash income or Adjusted Gross } \\
\text { Income (AGI)? }\end{array}$ & 1 & & \\
\hline 2. Is the unit of analysis families or households? & 1 & & \\
\hline 3. Is the percent change in after-tax income included in the analysis? & 1 & & \\
\hline 4. Is the percent of total tax change included in the analysis? & & 0 & \\
\hline 5. Are payroll taxes included in the analysis of taxes paid? & 1 & & \\
\hline 6. Is the number of taxpayers residing within the income categories omitted? & 1 & & \\
\hline 7. Are ranges of income associated with each income category omitted? & & 0 & \\
\hline 8. Are ranges of tax liability associated with each income category omitted? & 1 & & \\
\hline $\begin{array}{l}\text { 9. Are the current and proposed percent of total taxes paid for each income } \\
\text { category omitted? }\end{array}$ & & 0 & \\
\hline 10. Are the current and proposed tax rates for each income category omitted? & 1 & & \\
\hline
\end{tabular}


Applying the three scoring methods of the TDTSI to the OTA table give the following results. Using the first method of simply summing the responses, the OTA table exhibits liberal characteristics in 7 out of 10 questions, or $70 \%$. The second approach yields a result that indicates the table has left-leaning characteristics $7 / 10$ or 0.70 (70\%) and right-leaning characteristics $3 / 10$ or $0.30(30 \%)$. The third approach also results in a score that is left leaning $.40[(7-3) / 10]$.

Surprisingly, the table prepared by the OTA presents the share of taxes paid (TDTSI Question \#9). Typically, tax shares are considered to be a variable of concern to conservatives, not to liberals. However, the presentation of tax share information in this table supports the administration's contention that the upper-income groups would bear a higher percentage of total federal taxes as a result of the law.

It should be noted that even though the table does not present information relating to the percent of total tax change (TDTSI Question \#4), the information can be calculated with what information is presented. However, most lawmakers and public end-users of distribution tables will not realize that this variable can be calculated. Therefore, percent of total tax change is considered for purposes of the TDTSI to be omitted. The utility of the TDTSI lies in its ability to assist end-users in readily identifying information that should be explicitly presented in order to provide a balanced perspective.

The OTA table supports the contention made by Democrats that the provisions in OBRA 93 were progressive in nature and put most of the burden on those making over $\$ 200,000$. Further, taxpayers having incomes less $\$ 20,000$ are shown to be receiving a tax cut. 
Table 7-3. Congressional Budget Office

\begin{tabular}{|c|c|c|c|c|c|c|c|c|}
\hline \multicolumn{9}{|c|}{$\begin{array}{l}\text { Table 7-3. Tax Burdens Before and After the } 1993 \text { OBRA, by Adjusted Family Income and by Family Dollar Income } \\
\text { (1994 income levels and } 1998 \text { law) }\end{array}$} \\
\hline & \multicolumn{3}{|c|}{ All Federal Taxes } & \multicolumn{2}{|c|}{ Income after Taxes } & \multicolumn{2}{|c|}{ Effective Tax Rates } & \multirow[b]{2}{*}{$\begin{array}{l}\text { Share of Total } \\
\text { Change }\end{array}$} \\
\hline & Average & Change & $\begin{array}{l}\text { Percent } \\
\text { change }\end{array}$ & Average & $\begin{array}{l}\text { Percent } \\
\text { change }\end{array}$ & $\begin{array}{c}\text { Current } \\
\text { law }\end{array}$ & $\begin{array}{l}\text { With } \\
\text { option }\end{array}$ & \\
\hline \multirow{2}{*}{\multicolumn{9}{|c|}{ Families by Adjusted Family Income }} \\
\hline & & & & & & & & \\
\hline First & 589 & -166 & -28.1 & 7,878 & 2.1 & 7.0 & 5.0 & -8.3 \\
\hline Second & 3,119 & -35 & -1.1 & 17,623 & 0.2 & 15.0 & 14.9 & -1.8 \\
\hline Third & 6,498 & 64 & 1.0 & 27,156 & -0.2 & 19.3 & 19.5 & 3.2 \\
\hline Fourth & 10,800 & 110 & 1.0 & 38,172 & -0.3 & 22.1 & 22.3 & 5.7 \\
\hline Fifth & 29,203 & 1,884 & 6.5 & 82,111 & -2.3 & 26.2 & 27.9 & 100.9 \\
\hline All Quintiles & 10,107 & 382 & 3.8 & 34,129 & -1.1 & 22.8 & 23.7 & 100.0 \\
\hline Top 10 & 41,225 & 3,473 & 8.4 & 111,727 & -3.1 & 27.0 & 29.2 & 94.6 \\
\hline Top 5 & 59,374 & 6,521 & 11.0 & 157,427 & -4.1 & 27.4 & 30.4 & 89.4 \\
\hline Top 1 & 158,719 & 29,417 & 18.5 & 408,157 & -7.2 & 28.0 & 33.2 & 76.3 \\
\hline $81-90 \%$ & 16,757 & 239 & 1.4 & 51,452 & -0.5 & 24.6 & 24.9 & 6.3 \\
\hline $91-95 \%$ & 22,859 & 388 & 1.7 & 65,483 & -0.6 & 25.9 & 26.3 & 5.3 \\
\hline $96-99 \%$ & 36,188 & 1,177 & 3.3 & 98,908 & -1.2 & 26.8 & 27.7 & 13.1 \\
\hline \multicolumn{9}{|c|}{ Families with children } \\
\hline First & 559 & -380 & -68.0 & 10,493 & 3.6 & 5.1 & 1.6 & -25.8 \\
\hline Second & 4,811 & -134 & -2.8 & 13,585 & 0.6 & 16.9 & 16.5 & -8.8 \\
\hline Third & 9,665 & 73 & 0.8 & 35,240 & -0.2 & 21.5 & 21.7 & 4.7 \\
\hline Fourth & 15,305 & 144 & 0.9 & 49,663 & -0.3 & 23.6 & 23.8 & 8.1 \\
\hline $81-90 \%$ & 22,402 & 223 & 1.0 & 66,243 & -0.3 & 25.3 & 25.5 & 5.0 \\
\hline Top 10 & 54,694 & 6,450 & 11.8 & 147,793 & -4.4 & 27.0 & 30.2 & 116.5 \\
\hline All Quintiles & 11,178 & 336 & 3.0 & 37,610 & -0.9 & 22.9 & 23.6 & 100.0 \\
\hline \multicolumn{9}{|c|}{ Families with head age 65+ } \\
\hline First & 200 & 9 & 4.6 & 7,336 & -0.1 & 2.6 & 2.8 & 0.5 \\
\hline Second & 718 & 27 & 3.8 & 15,412 & -0.2 & 4.4 & 4.6 & 1.6 \\
\hline Third & 2,169 & 60 & 2.8 & 25,121 & -0.2 & 7.9 & 8.2 & 2.9 \\
\hline Fourth & 5,037 & 115 & 2.3 & 36,149 & -0.3 & 12.2 & 12.5 & 4.5 \\
\hline $81-90 \%$ & 10,178 & 651 & 6.4 & 50,892 & -1.3 & 16.7 & 17.7 & 10.4 \\
\hline Top 10 & 38,198 & 3,753 & 9.8 & 119,182 & -3.1 & 24.3 & 26.7 & 80.0 \\
\hline All Quintiles & 5,615 & 421 & 7.5 & 30,663 & -1.4 & 15.5 & 16.6 & 100.0 \\
\hline \multicolumn{9}{|l|}{ Other families } \\
\hline First & 876 & -37 & -4.3 & 5,276 & 0.7 & 14.2 & 13.6 & -1.4 \\
\hline Second & 3,060 & 25 & 0.8 & 13,066 & -0.2 & 19.0 & 19.1 & 1.0 \\
\hline Third & 5,842 & 58 & 1.0 & 20,787 & -0.3 & 21.9 & 22.2 & 2.5 \\
\hline Fourth & 9,843 & 86 & 0.9 & 31,412 & -0.3 & 23.9 & 24.1 & 4.7 \\
\hline $81-90 \%$ & 15,848 & 153 & 1.0 & 45,239 & -0.3 & 25.9 & 26.2 & 5.1 \\
\hline Top 10 & 37,798 & 2,450 & 6.5 & 98,197 & -2.5 & 27.8 & 29.6 & 87.7 \\
\hline All Quintiles & 11,308 & 399 & 3.5 & 33,074 & -1.2 & 25.5 & 26.4 & 100.0 \\
\hline \multicolumn{9}{|c|}{ Families by Dollar Income } \\
\hline Less than $\$ 10,000$ & 455 & -68 & -14.9 & 5,577 & 1.2 & 7.5 & 6.4 & -2.5 \\
\hline $10,000-20,000$ & 1,718 & -86 & -5.0 & 13,258 & 0.6 & 11.5 & 10.9 & -3.9 \\
\hline $20,000-30,000$ & 4,240 & -41 & -1.0 & 20,775 & 0.2 & 16.9 & 16.8 & -1.7 \\
\hline $30,000-40,000$ & 6,891 & 50 & 0.7 & 27,970 & -0.2 & 19.8 & 19.9 & 1.6 \\
\hline $40,000-50,000$ & 9,667 & 105 & 1.1 & 35,062 & -0.3 & 21.6 & 21.8 & 2.7 \\
\hline $50,000-75,000$ & 14,295 & 192 & 1.3 & 46,719 & -0.4 & 23.4 & 23.7 & 7.8 \\
\hline $75,000-100,000$ & 21,604 & 312 & 1.4 & 64,185 & -0.5 & 25.2 & 25.5 & 5.6 \\
\hline $100,000-200,000$ & 33,910 & 649 & 1.9 & 95,854 & -0.7 & 26.1 & 26.6 & 8.8 \\
\hline 200,000 or more & 135,359 & 23,521 & 17.4 & 350,578 & -6.7 & 27.9 & 32.7 & 81.3 \\
\hline All Incomes & 10,107 & 382 & 3.8 & 34,129 & -1.1 & 22.8 & 23.7 & 100.0 \\
\hline \multicolumn{9}{|c|}{$\begin{array}{l}\text { Notes: Figures are based on January } 1993 \text { economic assumptions. Pretax family income is the sum of wages, salaries, self-employment } \\
\text { income, rents, taxable and nontaxable interest, dividends, realized capital gains, and all cash transfer payments. Income also } \\
\text { includes the employer share of social security and federal unemployment insurance payroll taxes, and the corporate income tax. } \\
\text { For purposes of ranking by adjusted family income, income for each family is divided by the projected } 1994 \text { poverty threshold for } \\
\text { a family of that size. Quintiles contain equal numbers of people. Families with zero or negative income are excluded from the } \\
\text { lowest income category but included in the total. } \\
\text { Changes in individual income taxes, premiums, and entitlements are distributed directly to families paying those taxes and } \\
\text { premiums, or receiving those benefits. Changes in payroll taxes are distributed to families paying those taxes directly, or indirectly } \\
\text { through their employers. Changes in federal excise taxes are distributed to families according to their income from capital. } \\
\text { Source: Congressional Budget Office, as reprinted by Barthold, Nunns, and Toder in Bradford (Editor) (1995), pages 97-98. }\end{array}$} \\
\hline
\end{tabular}


Jason J. Fichtner

\begin{tabular}{|c|c|c|c|}
\hline $\begin{array}{l}\text { Tax Distribution Table Scoring Index (TDTSI) Analysis Tool for Revealing } \\
\text { Methodology, Content and Presentation in Tax Distribution Tables }\end{array}$ & $\begin{array}{l}\text { Yes - } \\
\text { Score } \\
\text { as “1” }\end{array}$ & $\begin{array}{c}\text { No- } \\
\text { Score } \\
\text { as "0" }\end{array}$ & $\begin{array}{l}\text { Can Not Be } \\
\text { Determined }\end{array}$ \\
\hline $\begin{array}{l}\text { 1. Is a measure of income used other than cash income or Adjusted Gross } \\
\text { Income (AGI)? }\end{array}$ & 1 & & \\
\hline 2. Is the unit of analysis families or households? & 1 & & \\
\hline 3. Is the percent change in after-tax income included in the analysis? & 1 & & \\
\hline 4. Is the percent of total tax change included in the analysis? & 1 & & \\
\hline 5. Are payroll taxes included in the analysis of taxes paid? & 1 & & \\
\hline 6. Is the number of taxpayers residing within the income categories omitted? & 1 & & \\
\hline 7. Are ranges of income associated with each income category omitted? & 1 & & \\
\hline 8. Are ranges of tax liability associated with each income category omitted? & 1 & & \\
\hline $\begin{array}{l}\text { 9. Are the current and proposed percent of total taxes paid for each income } \\
\text { category omitted? }\end{array}$ & 1 & & \\
\hline 10. Are the current and proposed tax rates for each income category o & & 0 & \\
\hline
\end{tabular}

At first glance, the CBO table might appear to be balanced. The CBO table includes a cashbased income measure, which would not be a liberal-leaning measure. However, upon further inspection of the footnotes, CBO discloses that it creates a specialized income measure by dividing each family's income by a poverty threshold for a family of its size. This has the effect of completely rearranging the observations both up and down the income ladder in a manner that is unobservable to end-users. The CBO's method results in many families with lower incomes receiving smaller income amounts, thus overstating income inequality and tax progressivity.

A report on CBO's methodology published by The Tax Foundation "reviewed the empirical methods used by the CBO to conduct tax distribution studies and found that the CBO's measures of income inequality and tax progressivity are not unbiased estimates of the actual distributions of income and taxes. Instead, the CBO's methods were found to produce results that systematically overstate the extent of income inequality and tax progressivity."123 Note that the CBO table omits providing income ranges for the quintiles where adjusted family income was utilized, but then provides dollar ranges when dollar income is used at the bottom portion of the table. Therefore, the CBO's income measure is not a cash-based or AGI-based income measure, but rather an adjusted family income measure and needs to be scored as such in the TDTSI. Also, the CBO table reveals that the fifth quintile will bear over 100 percent of the total increase in taxes.

Applying the three scoring methods of the TDTSI to the CBO table give the following results. Using the first method of simply summing the responses, the CBO table exhibits liberal characteristics in 9 out of 10 questions, or $90 \%$. The second approach yields a result that indicates the table balances liberal and conservative perspectives $9 / 10$ or $0.90(90 \%)$ and rightleaning characteristics $1 / 10$ or $0.10(10 \%)$. The third approach also results in a score that is left leaning .80 [(9-1)/10].

\footnotetext{
${ }^{123}$ Patrick J. Wilkie, “A Critical Analysis of Tax Distribution Studies Conducted by the Congressional Budget Office.” Tax Foundation Background Paper \#2, The Tax Foundation (Washington, DC: November 18, 1992).
} 
Applying the three scoring methods of the TDTSI to the CTJ table give the following results. Note that were a question cannot be determined from the information presented in the table or footnotes, a Don't Know ("DK”) is recorded. For purposes of the TDTSI, a "DK” is not counted in the scoring index. Therefore, using the first method of simply summing the responses, the CTJ table exhibits liberal characteristics in 7 out of 8 questions, or $87.5 \%$. The second approach yields a result that indicates the table presents liberal characteristics $7 / 8$ or $0.875(87.5 \%)$ and right-leaning characteristics $1 / 8$ or $0.125(12.5 \%)$. The third approach also results in a score that is left-leaning with a score of $0.75[(7-1) / 8]$.

The table above by the Citizens for Tax Justice easily tilts in the direction of biasing any debate toward "class warfare" assertions focusing only on which groups would get how much, while completely ignoring the distribution of the current tax burden. From the data in Table 7-4, the CTJ table clearly shows that upper income groups would receive a hefty tax break while the lower income groups would receive very little.

\section{Summary of TDTSI Results - Omnibus Budget Reconciliation Act of 1993}

With respect to the Omnibus Budget Reconciliation Act of 1993, the application of the TDTSI to tax distribution tables related to this bill is encouraging. The TDTSI effectively demonstrates that it can assist end-users of distribution tables in identifying presentations of data that are misleading or biased toward one perspective or another. Also, while the TDTSI did label the OTA, CBO and CTJ tables have having a liberal-leaning perspective, the TDTSI did not label the JCT table (under a period when the Democrats controlled both the House and Senate) as having a liberal-leaning bend, which one might expect if the perspectives of the Democrats in power were being presented through the JCT's tax distribution tables. Either the TDTSI failed to properly identify the perspectives presented in the JCT table, or the TDTSI supports that the JCT table in fact presents a balanced perspective.

\section{Taxpayer Relief Act of 1997 (TRA 97)}

The Taxpayer Relief Act of 1997 was passed in August 1997 during the presidency of Democrat Bill Clinton ( $2^{\text {nd }}$ term) and at a time when the Republicans had gained the majority of both the House of Representatives and the Senate. Since a Democrat controlled the White House and the Republicans controlled the Congress, the bill required the support of both parties if it were to become law. Hence, the bill contained provisions that were designed to get enough votes to pass.

The main tax provisions of TRA 97:

- established a \$500 child tax credit;

- $\quad$ established HOPE and Lifetime Learning education tax credits;

- extended air transportation excise taxes;

- $\quad$ phased-in an increase in estate tax exemption equivalent from $\$ 600,000$ to $\$ 1$ million in 2006;

- lowered the top capital gains tax rate from $28 \%$ to $20 \%$; 
- established Roth IRAs; increased income limits for deductible IRAs;

- conformed AMT depreciation lives to regular tax lives;

- phased-in 15-cent per pack increase in cigarette tax; and

- established education IRAs. ${ }^{124}$

A New York Times article captured the reaction to the provisions contained in a markup of the legislation from all sides:

Offering a preview of the rancorous debate that lies ahead, interest groups pounced on the tax package proposed today by the chairman of the House Ways and Means Committee, with some calling the tax cuts too limited and others calling them too generous to the wealthy...

Citizens for Tax Justice, a tax research group, called the plan a "flimflam." "They have cooked the books so much that French chefs would be jealous of this fine work," said Robert S. McIntyre, the director of the group...

The nation's largest lobbying group for small businesses, the National Federation of Independent Business, said that while it was pleased with much of the plan, it found the proposed changes on estate taxes - increasing the current $\$ 600,000$ exemption to $\$ 1$ million over the next 17 years - too limited...

One major provision of the tax package, the per-child tax credit, was also part of the House Republicans' Contract With America, and Mr. Archer said it would benefit the families of 41 million children under the age of $17 \ldots$

A major lobbying group for big business and Wall Street gave its approval to the proposed cut in capital gains taxes. The proposal would reduce the current 28 percent rate to 10 percent for couples making less than $\$ 41,200$ a year and would set the rate at 20 percent for people in higher income brackets. ${ }^{125}$

TRA 97 was a bill designed to please everyone in order to pass, but almost ended up pleasing no one. Generally, conservatives were pleased with the provisions of the bill that lowered capital gains taxes, expanded opportunities for IRAs, and increased the estate tax exemption. Liberals tended to support education credits but critically attacked what they felt were overly generous tax cuts to upper income groups. There were supporters and critics on both sides regarding the child tax credit. But what perspectives were presented in the tax distribution tables relating to TRA 97? The following three tables provide examples of tables released by the Congressional Joint Committee on Taxation, the Treasury's Office of Tax Analysis under the Clinton Administration, and Citizens for Tax Justice. While each of these groups released several iterations of tables as proposed changes to the tax bill became available, each of the tables below is consistent with the presentations of data for that group during this time period.

\footnotetext{
124 Jerry Tempalski, "Revenue Effects of Major Tax Bills," U.S. Department of the Treasury, Office of Tax Analysis, OTA Paper 81 (Revised July 2003).

125 Jerry Gray, “Congress and Taxes: The Reaction; Potshots From All Sides Offer Tax-Fight Preview,” The New York Times, June 10, 1997.
} 


\section{Table 7-5. Joint Committee on Taxation}

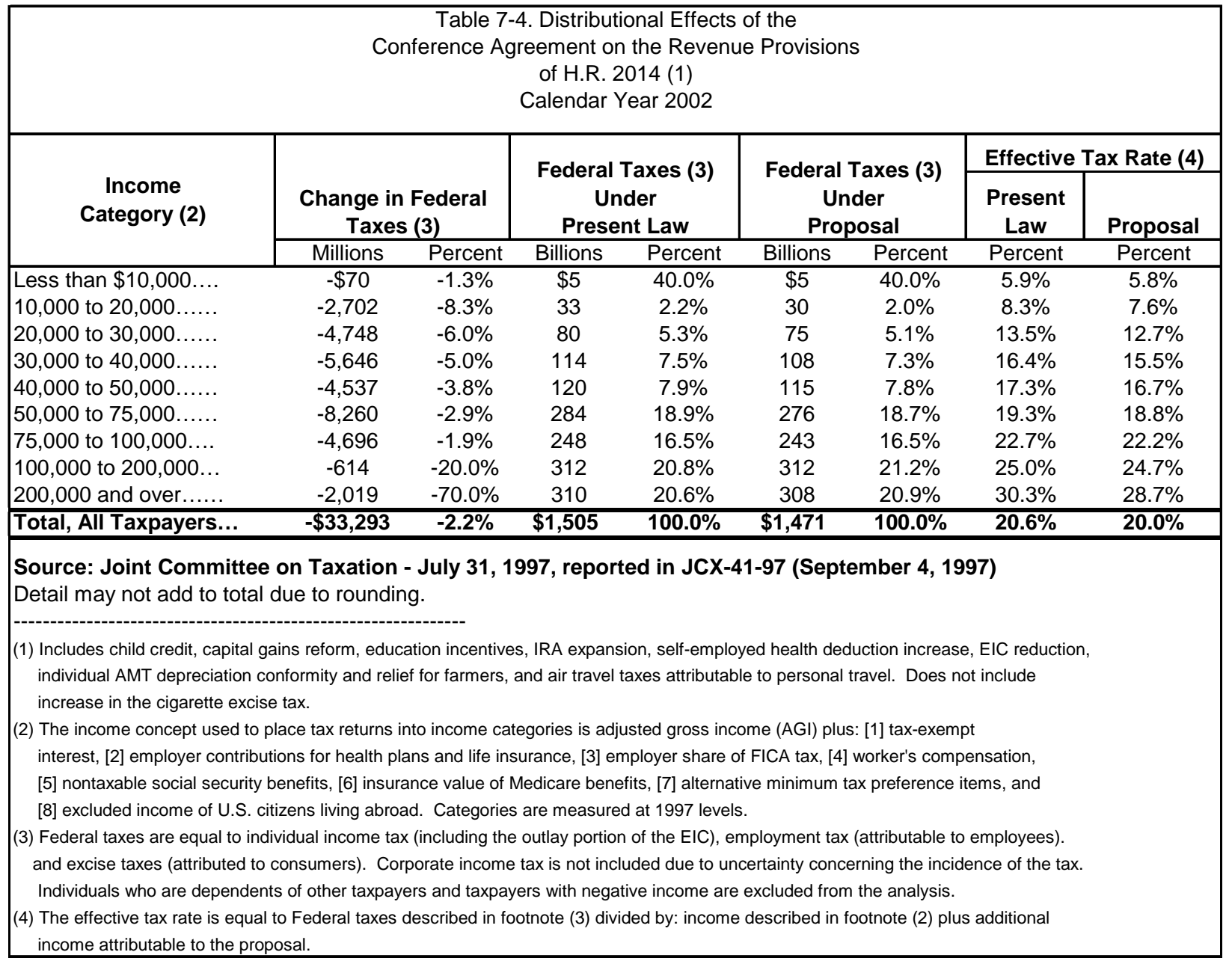

\begin{tabular}{|c|c|c|c|}
\hline $\begin{array}{l}\text { Tax Distribution Table Scoring Index (TDTSI) Analysis Tool for Revealing } \\
\text { Methodology, Content and Presentation in Tax Distribution Tables }\end{array}$ & $\begin{array}{l}\text { Yes - } \\
\text { Score } \\
\text { as "1" }\end{array}$ & $\begin{array}{l}\text { No- } \\
\text { Score } \\
\text { as “0" }\end{array}$ & $\begin{array}{l}\text { Can Not Be } \\
\text { Determined }\end{array}$ \\
\hline $\begin{array}{l}\text { 1. Is a measure of income used other than cash income or Adjusted Gross } \\
\text { Income (AGI)? }\end{array}$ & & 0 & \\
\hline 2. Is the unit of analysis families or households? & & 0 & \\
\hline 3. Is the percent change in after-tax income included in the analysis? & & 0 & \\
\hline 4. Is the percent of total tax change included in the analysis? & & 0 & \\
\hline 5. Are payroll taxes included in the analysis of taxes paid? & 1 & & \\
\hline 6. Is the number of taxpayers residing within the income categories omitted? & 1 & & \\
\hline 7. Are ranges of income associated with each income category omitted? & & 0 & \\
\hline 8. Are ranges of tax liability associated with each income category omitted? & 1 & & \\
\hline $\begin{array}{l}\text { 9. Are the current and proposed percent of total taxes paid for each income } \\
\text { category omitted? }\end{array}$ & & 0 & \\
\hline 10. Are the current and proposed tax rates for each income category omitted? & & 0 & \\
\hline
\end{tabular}


The JCT table analyzing the distributional effects of the conference agreement related to TRA 97 is different than the presentation of data used the JCT for OBRA 93. At the time of TRA 97, Republicans controlled both the House and the Senate. The TDTSI is a useful tool for identifying the differences.

Applying the three scoring methods of the TDTSI to the JCT table give the following results. Using the first method of simply summing the responses, the JCT table exhibits liberal characteristics in 3 out of 10 questions, or 30\%. The second approach yields a result that indicates the table balances liberal and conservative perspectives $3 / 10$ or 0.30 (30\%) and rightleaning characteristics $7 / 10$ or $0.70(70 \%)$. The third approach also results in a score that is right-leaning with a score of negative 0.40 [(3-7) / 10].

As with the JCT table analyzing OBRA 93 (Chart 7-1), this JCT table presents liberal-leaning perspectives on questions \#5, \#6, and \#8. However, and more importantly, the JCT table analyzing TRA 97 now includes the percent of total taxes paid and the proposed tax rates for each income category. Presented in this manner, the perspective of the TRA 97 JCT is that the tax provisions are progressive in nature. While all income groups receive a reduction in tax, those with incomes over $\$ 100,000$ will actually bear more of the burden of total federal taxes than before and the lower-income groups will see their share of total taxes decline. This table, by focusing on percent of taxes paid, supports conservative tax policy perspectives. By omitting variables such as average tax cut amount or percent change in after-tax income, the table does not try to balance perspectives.

Although not addressed by the TDTSI, it is interesting to note that this JCT table no longer attempts to include the corporate income tax, due to the uncertainty of the incidence. In other words, the economists on the Joint Committee on Taxation now consider the economic literature to be unclear as to the ultimate incidence of the corporate tax burden (on what group does the corporate tax actually fall: consumers, employees/workers, or owners of capital). This is a change from the JCT table analyzing OBRA 93. Depending upon the incidence assumptions used, the corporate income tax is likely to be borne by taxpayers in higher income groups. Not including the corporate income tax in distributional analysis could therefore give the appearance that higher income groups are benefiting less from reductions to the cost of capital. 


\section{Table 7-6. Office of Tax Analysis}

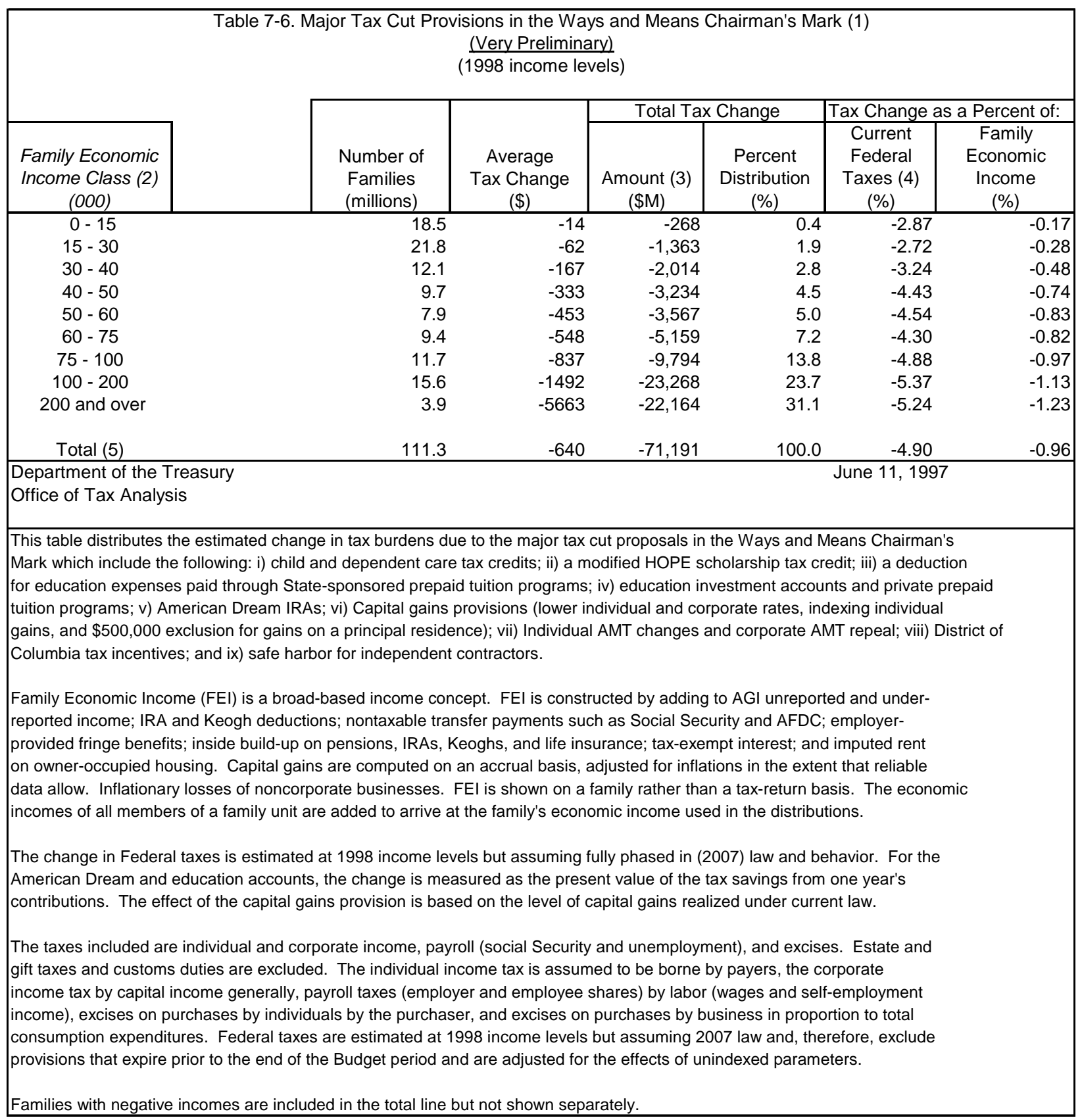




\begin{tabular}{|c|c|c|c|}
\hline $\begin{array}{l}\text { Tax Distribution Table Scoring Index (TDTSI) Analysis Tool for Revealing } \\
\text { Methodology, Content and Presentation in Tax Distribution Tables }\end{array}$ & $\begin{array}{l}\text { Yes - } \\
\text { Score } \\
\text { as “1" }\end{array}$ & $\begin{array}{l}\text { No- } \\
\text { Score } \\
\text { as "0" }\end{array}$ & $\begin{array}{l}\text { Can Not Be } \\
\text { Determined }\end{array}$ \\
\hline $\begin{array}{l}\text { 1. Is a measure of income used other than cash income or Adjusted Gross } \\
\text { Income (AGI)? }\end{array}$ & 1 & & \\
\hline 2. Is the unit of analysis families or households? & 1 & & \\
\hline 3. Is the percent change in after-tax income included in the analysis? & 1 & & \\
\hline 4. Is the percent of total tax change included in the analysis? & 1 & & \\
\hline 5. Are payroll taxes included in the analysis of taxes paid? & 1 & & \\
\hline 6. Is the number of taxpayers residing within the income categories omitted? & & 0 & \\
\hline 7. Are ranges of income associated with each income category omitted? & & 0 & \\
\hline 8. Are ranges of tax liability associated with each income category omitted? & 1 & & \\
\hline $\begin{array}{l}\text { 9. Are the current and proposed percent of total taxes paid for each income } \\
\text { category omitted? }\end{array}$ & 1 & & \\
\hline 10. Are the current and proposed tax rates for each income category omitted? & 1 & & \\
\hline
\end{tabular}

While the TRA 97 OTA table has a slightly different presentation than the OBRA 93 table (Table 7-2), much remains the same. Applying the three scoring methods of the TDTSI to the OTA table give the following results. Using the first method of simply summing the responses, the OTA table exhibits liberal characteristics in 8 out of 10 questions, or $80 \%$. The second approach yields a result that indicates the table leans heavily toward the liberal perspective $8 / 10$ or 0.80 (80\%) and right-leaning characteristics $2 / 10$ or 0.20 (20\%). The third approach also results in a score that is left leaning .60 [(8 - 2) / 10].

By presenting information on average tax cut amount, the table gives the perspective that the rich overly benefit by receiving over a $\$ 5,000$ tax cut while the lowest income group gets only $\$ 14$. The OTA table supports the contention made by Democrats that the provisions in TRA 97 were heavily skewed toward the rich and unfair to the poor. However, without providing data on percent of taxes paid, the OTA table makes no attempt to balance perspectives. 
Table 7-7. Citizens for Tax Justice

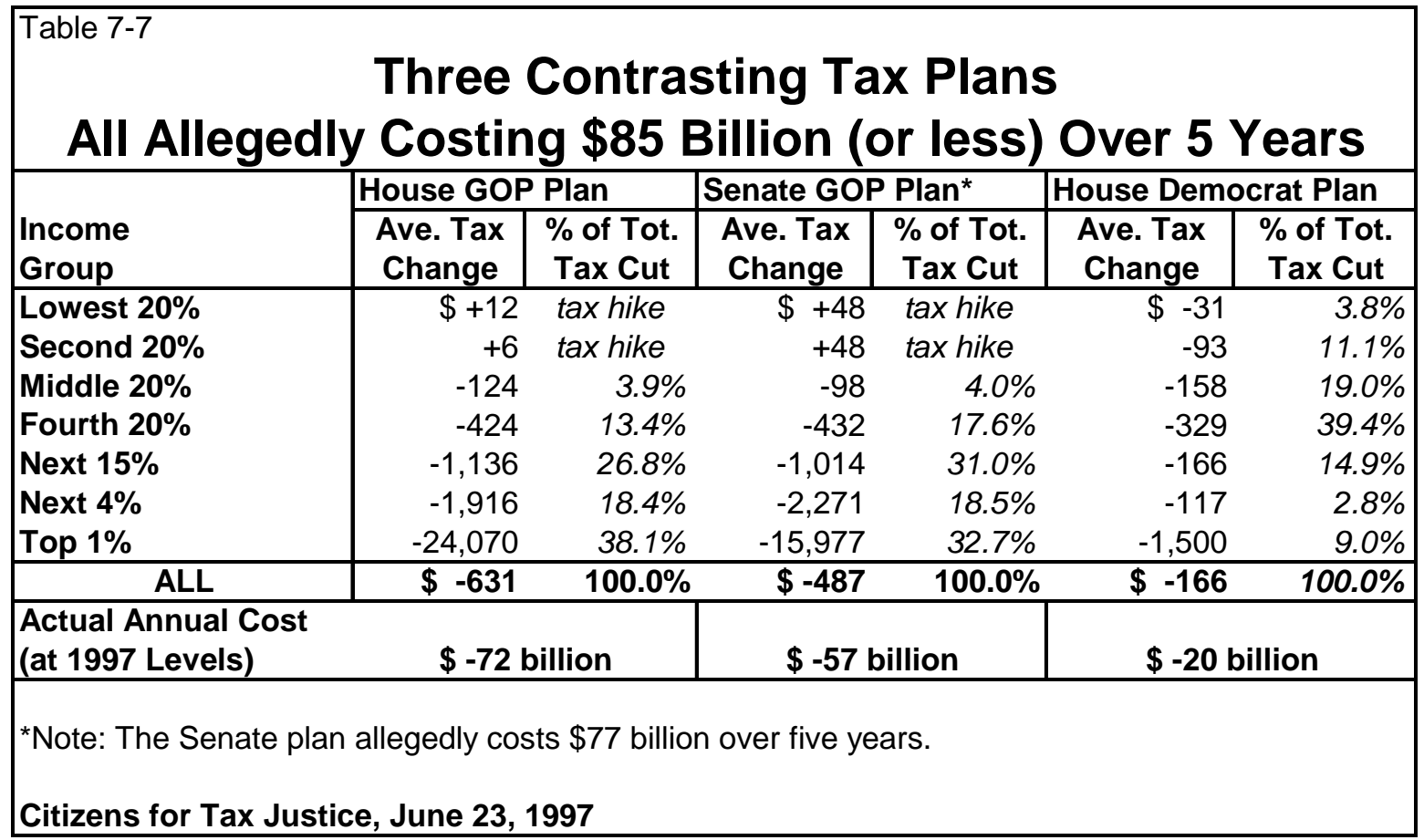

\begin{tabular}{|c|c|c|c|}
\hline $\begin{array}{l}\text { Tax Distribution Table Scoring Index (TDTSI) Analysis Tool for Revealing } \\
\text { Methodology, Content and Presentation in Tax Distribution Tables }\end{array}$ & $\begin{array}{l}\text { Yes - } \\
\text { Score } \\
\text { as “1" }\end{array}$ & $\begin{array}{l}\text { No- } \\
\text { Score } \\
\text { as “0” }\end{array}$ & $\begin{array}{l}\text { Can Not Be } \\
\text { Determined }\end{array}$ \\
\hline $\begin{array}{l}\text { 1. Is a measure of income used other than cash income or Adjusted Gross } \\
\text { Income (AGI)? }\end{array}$ & & & DK \\
\hline 2. Is the unit of analysis families or households? & & & DK \\
\hline 3. Is the percent change in after-tax income included in the analysis? & & 0 & \\
\hline 4. Is the percent of total tax change included in the analysis? & 1 & & \\
\hline 5. Are payroll taxes included in the analysis of taxes paid? & & & DK \\
\hline 6. Is the number of taxpayers residing within the income categories omitted? & 1 & & \\
\hline 7. Are ranges of income associated with each income category omitted? & 1 & & \\
\hline 8. Are ranges of tax liability associated with each income category omitted? & 1 & & \\
\hline $\begin{array}{l}\text { 9. Are the current and proposed percent of total taxes paid for each income } \\
\text { category omitted? }\end{array}$ & 1 & & \\
\hline 10. Are the current and proposed tax rates for each income category omittec & 1 & & \\
\hline
\end{tabular}

During the TRA 97 tax debate, CTJ released numerous press releases containing tax distribution tables. However, like Table 7-7, most showed only average tax cut amount and percent of total tax change. Very little supporting information was provided.

Applying the three scoring methods of the TDTSI to the CTJ table give the following results. Note that where a question cannot be determined from the information presented in the table or footnotes, a Don't Know ("DK") is recorded. For purposes of the TDTSI, a "DK" is not counted in the scoring index. Therefore, using the first method of simply summing the responses, the CTJ table exhibits liberal characteristics in 6 out of 7 questions, or $86 \%$. The second approach 
yields a result that indicates the table presents liberal characteristics $6 / 7$ or 0.857 (86\%) and right-leaning characteristics $1 / 7$ or $0.142(14 \%)$. The third approach also results in a score that is left-leaning with a score of $0.714[(6-1) / 7]$.

The table above by the Citizens for Tax Justice easily tilts in the direction of biasing any debate toward "class warfare" assertions focusing only on which groups would get how much, while completely ignoring the distribution of the current tax burden. From the data in Table 7-6, the CTJ table clearly shows that upper income groups would receive a hefty tax break while the lower income groups somehow get a tax increase (though no explanation is given as to how).

The CTJ table fails to discuss or disclose the current distribution of taxes under current law. Further, CTJ fails to disclose in this table the income concept used in its analysis and whether families or tax returns are the unit of analysis. Although the CTJ table is categorized by quintiles or percentage groupings, since the total number of taxpayers is not presented, the number of taxpaying units per income class cannot be determined. There is also no disclosure on which existing taxes are included in the analysis (i.e., income, payroll, estate and gift, etc.)

\section{Summary of TDTSI Results - Taxpayer Relief Act of 1997}

The application of the TDTSI to tax distribution tables analyzing the distributional effects of the Taxpayer Relief Act of 1997 is very positive. The TDTSI effectively demonstrates that it can assist end-users of distribution tables in identifying presentations of data that are misleading or biased toward one perspective or another. The TDTSI was successful in identifying the overall right-leaning perspectives in the JCT table (now under the authority of Republicans) and successful at identifying the overall left-leaning perspectives in the OTA table (under the authority of a Democrat in the White House). End-users of either the JCT or OTA table would be able to use the TDTSI to balance perspectives and, hopefully, gain a more balanced understanding of the distributional effects of TRA 97.

Further, the TDTSI demonstrated that it is also an effective tool even when information cannot be determined, as with the CTJ table. Additionally, the TDTSI effectively labeled the CTJ table as liberal-leaning and provides a warning that the presentation of the data is designed more to support the CTJ's political viewpoints than to illuminate the nuances of the tax plan and add to the general debate. 


\section{Economic Growth and Tax Relief Reconciliation Act of 2001(EGTRRA 01)}

The Economic Growth and Tax Relief Reconciliation Act of 2001 was signed into law June 7, 2001 during the first term of President George W. Bush and at a time when the Republicans were in the majority of both the House of Representatives and the Senate in the $107^{\text {th }}$ Congress. However, on May 24, 2001, Senator James Jeffords of Vermont announced his switch from Republican to Independent status, effective June 6, 2001. His party switch turned the control of the Senate back over to the Democrats. The Republicans gained back the Senate at the start of the $108^{\text {th }}$ Congress.

The main tax provisions of EGTRRA 01:

- lower individual tax rates;

- lowered the 39.6\% top tax rate created under OBRA 93 to 35\%.;

- increase in the child tax credit to $\$ 1,000$;

- phased-in an increase in the estate tax exemption toward repeal of the estate tax (thru 2010);

- phased-in marriage penalty relief;

- phased-in repeal of the limit on itemized deductions;

- increased the individual Alternative Minimum Tax exemption to $\$ 35,750$ for single filers and $\$ 49,000$ for couples filing jointly;

- phased-in repeal of the limit on personal exemptions;

- created above-the-line deductions for higher education expenses; and

- increased Education IRA contribution limit to $\$ 2,000$. $^{126}$

EGTRRA 01 did not become law until June 2001. But the debate started much earlier. A July 1999 Washington Post news article reports "Despite renewed White House opposition yesterday, the Senate appears poised to approve a giant $\$ 792$ billion tax cut bill...”127 The Post article also reports "President Clinton and Vice President Gore mounted coordinated attacks on GOP tax cutting, charging that it was premised on phony budget assumptions and could undermine efforts to bolster Medicare and Social Security." ${ }^{2128}$ The partisan wrangling was just a preview of what was to come.

The 2000 presidential election and the following $107^{\text {th }}$ Congress were indeed interesting times. The debate over the provision that eventually were included in EGTRRA 01 heated up as part of the campaign cycle with George W. Bush campaigning on a platform of tax cuts and the Republicans in the House and Senate supportive. The battle of opposing tax distribution information was displayed in major newspapers with The Washington Post describing:

Fearing that they are losing the public relations battle over taxes, Clinton administration officials yesterday stepped up efforts to convince voters that the

\footnotetext{
${ }^{126}$ Jerry Tempalski, "Revenue Effects of Major Tax Bills," U.S. Department of the Treasury, Office of Tax Analysis, OTA Paper 81 (Revised July 2003).

${ }^{127}$ Eric Pianin and Helen Dewar, “Senate GOP Tax Bill May Lead to Deal,” The Washington Post, July 28, 1999.

${ }^{128}$ Ibid.
} 
bevy of GOP-crafted tax bills racing through Congress would shower most of their benefits on the wealthiest Americans...

Republicans on the Joint Economic Committee, in a pair of studies, have argued that distributional analyses, such as those issued by Treasury yesterday, are inherently misleading in a progressive tax system in which the wealthiest pay most of the taxes - and one-third of Americans already pay no taxes." ${ }^{\text {"129 }}$

Similar perspectives were expressed after the election as the tax bill gained momentum towards becoming law:

Democrats say that a tax cut that rewards such a small sliver of society is unfair to the millions of Americans who will receive little or nothing under the bill. Republicans argue that the wealthy pay most of the income taxes, and so it is only fair that they should reap most of the benefits of a tax cut. ${ }^{130}$

Many of the news articles covering the tax debate contained graphics of abbreviated tax distribution tables to support their stories. The TDTSI is applied to four distribution tables, one prepared by the Joint Committee on Taxation, two by the Office of Tax Analysis (under both President Clinton and President Bush), and one by Citizens for Tax Justice.

${ }^{129}$ Glenn Kessler and Eric Pianin, "White House Strikes Back on Tax Cuts,” The Washington Post, July 18, 2000.

${ }^{130}$ Glenn Kessler, “Tax Cut Debate’s Division Problem,” The Washington Post, May 17, 2001. 
Table 7-8. Joint Committee on Taxation.

\begin{tabular}{|c|c|c|c|c|c|c|c|c|}
\hline \multicolumn{9}{|c|}{$\begin{array}{c}\text { DISTRIBUTIONAL EFFECTS OF THE } \\
\text { CONFERENCE AGREEMENT FOR H.R.1836 (1) } \\
\text { Calendar Year } 2006\end{array}$} \\
\hline \multirow[t]{2}{*}{$\begin{array}{l}\text { INCOME } \\
\text { CATEGORY (2) }\end{array}$} & \multicolumn{2}{|c|}{$\begin{array}{l}\text { CHANGE IN } \\
\text { FEDERAL } \\
\text { TAXES (3) }\end{array}$} & \multicolumn{2}{|c|}{$\begin{array}{l}\text { FEDERAL TAXES (3) } \\
\text { UNDER } \\
\text { PRESENT LAW } \\
\end{array}$} & \multicolumn{2}{|c|}{$\begin{array}{c}\text { FEDERAL TAXES (3) } \\
\text { UNDER } \\
\text { PROPOSAL }\end{array}$} & \multicolumn{2}{|c|}{$\begin{array}{l}\text { Effective Tax Rate (4) } \\
\text { Present } \\
\text { Law Proposa }\end{array}$} \\
\hline & Millions & Percent & Billions & Percent & Billions & Percent & Percent & Percent \\
\hline Less than $\$ 10,000 \ldots \ldots \ldots$ & $-\$ 76$ & $-0.9 \%$ & $\$ 8$ & $0.4 \%$ & $\$ 8$ & $0.4 \%$ & $10.4 \%$ & $10.3 \%$ \\
\hline 10,000 to $20,000 \ldots \ldots \ldots$ & $-3,789$ & $-13.6 \%$ & 28 & $1.2 \%$ & 24 & $1.1 \%$ & $7.6 \%$ & $6.6 \%$ \\
\hline 20,000 to $30,000 \ldots \ldots \ldots$ & $-7,853$ & $-11.4 \%$ & 69 & $3.1 \%$ & 61 & $2.9 \%$ & $13.7 \%$ & $12.2 \%$ \\
\hline 30,000 to $40,000 \ldots \ldots \ldots$ & $-7,839$ & $-7.9 \%$ & 99 & $4.4 \%$ & 91 & $4.4 \%$ & $16.0 \%$ & $14.7 \%$ \\
\hline 40,000 to $50,000 \ldots \ldots \ldots$ & $-7,570$ & $-6.5 \%$ & 116 & $5.2 \%$ & 108 & $5.2 \%$ & $17.2 \%$ & $16.0 \%$ \\
\hline 50,000 to $75,000 \ldots \ldots \ldots$ & $-18,755$ & $-6.0 \%$ & 313 & $14.0 \%$ & 294 & $14.0 \%$ & $18.6 \%$ & $17.5 \%$ \\
\hline 75,000 to $100,000 \ldots \ldots \ldots$ & $-17,212$ & $-5.8 \%$ & 297 & $13.3 \%$ & 280 & $13.3 \%$ & $21.3 \%$ & $20.0 \%$ \\
\hline 100,000 to $200,000 \ldots \ldots .$. & $-30,208$ & $-5.1 \%$ & 588 & $26.3 \%$ & 558 & $26.6 \%$ & $23.9 \%$ & $22.7 \%$ \\
\hline 200,000 and over..... & $-44,177$ & $-6.1 \%$ & 719 & $32.1 \%$ & 675 & $32.1 \%$ & $28.3 \%$ & $26.6 \%$ \\
\hline Total, All Taxpayers..... & $-\$ 137,476$ & $-6.1 \%$ & $\$ 2,238$ & $100.0 \%$ & $\$ 2,100$ & $100.0 \%$ & $21.7 \%$ & $20.3 \%$ \\
\hline \multicolumn{9}{|c|}{$\begin{array}{l}\text { Source: Joint Committee on Taxation. JCX-52-01. May 26, } 2001 \\
\text { Detail may not add to total due to rounding. }\end{array}$} \\
\hline \multicolumn{9}{|c|}{$\begin{array}{l}\text { (1) Includes provisions affecting the child credit, individual marginal rates, a } 10 \% \text { bracket, limitation of itemized deductions, } \\
\text { the personal exemption phaseout, the standard deduction, 15\% bracket and EIC for married couples, deductible IRAs, } \\
\text { and the AMT. } \\
\text { (2) The income concept used to place tax returns into income categories is adjusted gross income (AGI) plus: [1] tax- } \\
\text { exempt interest, [2] employer contributions for health plans and life insurance, [3] employer share of FICA tax, [4] } \\
\text { worker's compensation, [5] nontaxable Social Security benefits, [6] insurance value of Medicare benefits, [7] alternative } \\
\text { minimum tax preference items, and [8] excluded income of U.S. citizens living abroad. Categories are measured at } 2001 \\
\text { levels. } \\
\text { (3) Federal taxes are equal to individual income tax (including the outlay portion of the EIC), employment tax (attributed to } \\
\text { employees), and excise taxes (attributed to consumers). Corporate income tax and estate and gift taxes are not included } \\
\text { due to uncertainty concerning the incidence of these taxes. Individuals who are dependents of other taxpayers and } \\
\text { taxpayers with negative income are excluded from the analysis. Does not include indirect effects. } \\
\text { (4) The effective tax rate is equal to Federal taxes described in footnote (3) divided by: income described in footnote (2) plus } \\
\text { additional income attributable to the proposal. }\end{array}$} \\
\hline
\end{tabular}

\begin{tabular}{|l|c|c|c|}
\hline $\begin{array}{l}\text { Tax Distribution Table Scoring Index (TDTSI) Analysis Tool for Revealing } \\
\text { Methodology, Content and Presentation in Tax Distribution Tables }\end{array}$ & $\begin{array}{c}\text { Yes - } \\
\text { Score } \\
\text { as “1” }\end{array}$ & $\begin{array}{c}\text { No- } \\
\text { Score } \\
\text { as “0” }\end{array}$ & $\begin{array}{c}\text { Can Not Be } \\
\text { Determined }\end{array}$ \\
\hline $\begin{array}{l}\text { 1. Is a measure of income used other than cash income or Adjusted Gross } \\
\text { Income (AGI)? }\end{array}$ & 0 & \\
\hline 2. Is the unit of analysis families or households? & & 0 & \\
\hline 3. Is the percent change in after-tax income included in the analysis? & & 0 & \\
\hline 4. Is the percent of total tax change included in the analysis? & 1 & & \\
\hline 5. Are payroll taxes included in the analysis of taxes paid? & 1 & & \\
\hline 6. Is the number of taxpayers residing within the income categories omitted? & & 0 & \\
\hline 7. Are ranges of income associated with each income category omitted? & & & \\
\hline 8. Are ranges of tax liability associated with each income category omitted? & 1 & 0 & \\
\hline $\begin{array}{l}\text { 9. Are the current and proposed percent of total taxes paid for each income } \\
\text { category omitted? }\end{array}$ & & & \\
\hline 10. Are the current and proposed tax rates for each income category omitted? & & 0 & \\
\hline
\end{tabular}


Applying the three scoring methods of the TDTSI to the JCT table give the following results. Using the first method of simply summing the responses, the JCT table exhibits liberal characteristics in 3 out of 10 questions, or $30 \%$. The second approach yields a result that indicates the table presents liberal characteristics $3 / 10$ or 0.30 (30\%) and right-leaning characteristics $7 / 10$ or $0.70(70 \%)$. The third approach also results in a score that is right-leaning with a score of negative $0.40[(3-7) / 10]$.

This JCT table has the same TDTSI score as the JCT table analyzing TRA 97 (Chart 7-5) and also exhibits liberal-leaning perspectives on questions \#5, \#6, and \#8. Presented in this manner, the perspective of the EGTRRA 01 JCT table is that the tax provisions are progressive in nature. While all income groups receive a reduction in tax, those with incomes between $\$ 10,000$ and $\$ 20,000$ receive a higher percentage reduction in their federal taxes. This table, by focusing on percent of taxes paid, supports conservative tax policy perspectives. By omitting variables such as average tax cut amount or percent change in after-tax income, the table does not try to balance perspectives.

\section{Table 7-9. Clinton Administration Office of Tax Analysis, Department of the Treasury}

\begin{tabular}{|c|c|c|c|c|c|c|}
\hline \multicolumn{7}{|c|}{$\begin{array}{l}\text { Major Provisions Passed by the House Ways and Means Committee }{ }^{1} \\
(2000 \text { Income Levels) Very Preliminary }\end{array}$} \\
\hline \multirow[b]{2}{*}{ Family Economic Income ${ }^{2}$} & \multirow{2}{*}{$\begin{array}{l}\text { Number of } \\
\text { Families } \\
\text { (millions) }\end{array}$} & \multirow[b]{2}{*}{$\begin{array}{l}\text { Average Tax } \\
\text { Change (\$) }\end{array}$} & \multicolumn{2}{|c|}{ Total Tax Change } & \multicolumn{2}{|c|}{ Percent Change In: } \\
\hline & & & $\begin{array}{l}\text { Amount } \\
\text { (millions) }\end{array}$ & $\begin{array}{l}\text { Percent } \\
\text { Distribution (\%) }\end{array}$ & $\begin{array}{l}\text { Current Federal } \\
\text { Taxes }^{4}\end{array}$ & $\begin{array}{l}\text { After-Tax } \\
\text { Income } \\
(\%)\end{array}$ \\
\hline Lowest $^{6}$ & 22.4 & -13 & -286 & $0.4 \%$ & $-2.1 \%$ & $0.1 \%$ \\
\hline Second & 23.0 & -77 & $-1,762$ & $2.7 \%$ & $-2.5 \%$ & $0.3 \%$ \\
\hline Third & 23.0 & -192 & $-4,426$ & $6.8 \%$ & $-2.4 \%$ & $0.6 \%$ \\
\hline Fourth & 23.0 & -380 & $-8,748$ & $13.4 \%$ & $-2.4 \%$ & $0.6 \%$ \\
\hline Highest & 23.0 & $-2,164$ & $-49,877$ & $76.6 \%$ & $-4.2 \%$ & $1.4 \%$ \\
\hline Total $^{6}$ & 115.2 & -566 & $-65,131$ & $100.0 \%$ & $-3.6 \%$ & $1.0 \%$ \\
\hline Top 10\% & 11.5 & $-3,442$ & $-39,586$ & $60.9 \%$ & $-4.5 \%$ & $1.6 \%$ \\
\hline Top 5\% & 5.8 & $-5,632$ & $-32,490$ & $49.9 \%$ & $-4.9 \%$ & $1.8 \%$ \\
\hline Top 1\% & 1.2 & $-17,074$ & $-19,840$ & $30.5 \%$ & $-5.5 \%$ & $2.2 \%$ \\
\hline \\
\hline \multirow{2}{*}{\multicolumn{7}{|c|}{$\begin{array}{l}\text { Source: Department of the Treasury. Office of Tax Analysis. July 17, } \mathbf{2 0 0 0 .} \\
\text { (13) This table distributes the estimated change in tax burdens due to the following major provisions passed by the House Ways and Means Committee in H.R. 7, } \\
\text { H.R. 8, H.R. 2990, H.R. 3832, H.R. 3916, H.R. } 4810 \text { and H.R. } 4843 \text {. } \\
\text { (14) Family Economic Income (FEI) is a broad-based income concept. FEI is constructed by adding to AGI unreported and under-reported income; IRA and Keogh } \\
\text { deductions; nontaxable transfer payments such as Social Security and AFDC; employer-provided fringe benefits; inside build-up on pensions; IRAs, Keoghs, } \\
\text { and life insurance; tax-exempt interest; and imputed rent on owner-occupied housing. Capital gains are computed on an accrual basis, adjusted for inflation to } \\
\text { the extent that reliable data allow. Inflationary losses of lenders are subtracted and gains of borrowers are added. There is also an adjustment for accelerated } \\
\text { depreciation of noncorporate businesses. FEI is shown on a family rather than a tax-return basis. The economic incomes of all members of a family unit are } \\
\text { added to arrive at the family's economic income used in the distributions. }\end{array}$}} \\
\hline & & & & & & \\
\hline \multirow{2}{*}{\multicolumn{7}{|c|}{$\begin{array}{l}\text { (15) The change in Federal taxes is estimated at } 2000 \text { income levels assuming fully phased in law. Current and proposed taxes are estimated using FY2000 Budget } \\
\text { assumptions. The tax benefit of the increase in retirement contribution limits is measured as the present value of tax savings on one year's contributions. } \\
\text { (16) The taxes included are individual and corporate income, payroll, excises, customs duties, and estate and gift taxes. The individual income tax is assumed to be } \\
\text { borne by payers, the corporate income tax by capital generally, payroll taxes (employer and employee shares) by labor (wages and self-employment income), } \\
\text { excises on purchases by individuals in proportion to relative consumption of the taxed good and proportionately by labor and capital and excises on purchases } \\
\text { by businesses and customs duties proportionately to labor and capital, and the estate tax by decedents. Federal taxes are estimated at } 2000 \text { income levels but } \\
\text { assuming } 2009 \text { law and, therefore, exclude provisions that expire prior to the end of the Budget period and are adjusted for the effects of unindexed parameters. }\end{array}$}} \\
\hline & & & & & & \\
\hline \multicolumn{7}{|c|}{ (17) After-tax income is Family Economic Income less current Federal taxes. } \\
\hline \multicolumn{7}{|c|}{$\begin{array}{l}\text { (18) Families with negative incomes are excluded from the lowest quintile but included in the total line. } \\
\text { NOTE: Quintiles begin at FEI of: Second \$17,988; Third \$34,844; Fourth \$59,019; Highest \$100,767; Top 10\% \$140,581; Top 5\% \$189,835; Top 1\% \$462,053. }\end{array}$} \\
\hline
\end{tabular}




\begin{tabular}{|c|c|c|c|}
\hline $\begin{array}{l}\text { Tax Distribution Table Scoring Index (TDTSI) Analysis Tool for Revealing } \\
\text { Methodology, Content and Presentation in Tax Distribution Tables }\end{array}$ & $\begin{array}{l}\text { Yes - } \\
\text { Score } \\
\text { as “1" }\end{array}$ & $\begin{array}{l}\text { No- } \\
\text { Score } \\
\text { as “0" }\end{array}$ & $\begin{array}{l}\text { Can Not Be } \\
\text { Determined }\end{array}$ \\
\hline $\begin{array}{l}\text { 1. Is a measure of income used other than cash income or Adjusted Gross } \\
\text { Income (AGI)? }\end{array}$ & 1 & & \\
\hline 2. Is the unit of analysis families or households? & 1 & & \\
\hline 3. Is the percent change in after-tax income included in the analysis? & 1 & & \\
\hline 4. Is the percent of total tax change included in the analysis? & 1 & & \\
\hline 5. Are payroll taxes included in the analysis of taxes paid? & 1 & & \\
\hline 6. Is the number of taxpayers residing within the income categories omitted? & & 0 & \\
\hline 7. Are ranges of income associated with each income category omitted? & & 0 & \\
\hline 8. Are ranges of tax liability associated with each income category omitted? & 1 & & \\
\hline $\begin{array}{l}\text { 9. Are the current and proposed percent of total taxes paid for each income } \\
\text { category omitted? }\end{array}$ & 1 & & \\
\hline 10. Are the current and proposed tax rates for each income category omitted? & 1 & & \\
\hline
\end{tabular}

Table 7-9 was prepared by the OTA under the Clinton/Gore Administration and during the presidential campaign of 2000. Applying the TDTSI to the analysis of this table would provide affirmative responses for the following questions: 1, 2, 3, 4, 5, 8, 9, and 10. For Question \#7 (income ranges), the dollar cut-off points are provided for the quintiles in the notes.

Therefore, using the first method of simply summing the responses, the 2000 OTA table exhibits liberal characteristics in 8 out of 10 questions, or $80 \%$. The second approach yields a result that indicates the table has left-leaning characteristics $8 / 10$ or 0.80 (80\%) and right-leaning characteristics $2 / 10$ or 0.20 (20\%), showing a definite left-leaning tilt. The third approach results in a score that is left-leaning $0.60[(8-2) / 10]$.

Again, applying all three measures provides consistent results. Using the TDTSI to evaluate the Clinton OTA tax distribution table, the methodologies and presentations of data used in portray the results of an analysis to a change in tax law in a manner that is liberal-leaning.

The perspective presented in the 2000 OTA table suggests that the tax plan in question would be regressive and overly benefit the rich. But applying the TDTSI to the table provides a score that indicates liberal-leaning perspectives are being advanced that support redistribution of income and ignoring conservative perspectives, which are more concerned with which groups are paying for government as would be presented by showing a variable such as "current and proposed percent of total tax paid" (tax shares). 
Table 7-10. Bush Administration Office of Tax Analysis, Department of the Treasury

Major Individual Income Tax Provisions of the President's Tax Proposal ${ }^{1}$ (2000 Income Levels)

\begin{tabular}{|c|c|c|c|c|c|}
\hline \multirow[b]{2}{*}{ Cash Income Class $^{2}$} & \multirow{2}{*}{$\begin{array}{c}\text { Distribution of } \\
\text { Proposed } \\
\text { Changes in } \\
\text { Individual } \\
\text { Income Taxes } \\
(\%) \\
\end{array}$} & \multicolumn{2}{|c|}{$\begin{array}{c}\begin{array}{c}\text { Distribution of Total Individual } \\
\text { Income Taxes }^{3}\end{array} \\
\end{array}$} & \multirow{2}{*}{$\begin{array}{c}\text { Average Individual } \\
\text { Income Taxes With } \\
\text { Proposed Changes } \\
\text { (\$) }\end{array}$} & \multirow{2}{*}{$\begin{array}{l}\text { Percent Change in } \\
\text { Individual Income } \\
\text { Taxes } \\
(\%)\end{array}$} \\
\hline & & $\begin{array}{c}\text { Current Law } \\
(\%)\end{array}$ & $\begin{array}{c}\text { With Proposed } \\
\text { Changes }{ }^{4} \\
(\%)\end{array}$ & & \\
\hline $0-30$ & 9.3 & -1.0 & -2.8 & -457 & -136.2 \\
\hline $30-40$ & 6.5 & 2.5 & 1.8 & 993 & -38.3 \\
\hline $40-50$ & 7.8 & 4.1 & 3.4 & 2,210 & -28.0 \\
\hline $50-75$ & 17.2 & 12.2 & 11.3 & 4,279 & -20.8 \\
\hline $75-100$ & 13.6 & 12.2 & 12.0 & 7,848 & -16.3 \\
\hline $100-200$ & 19.8 & 27.1 & 28.3 & 16,625 & -10.7 \\
\hline 200 \& Over & 25.4 & 42.9 & 45.9 & 103,931 & -8.7 \\
\hline Total $^{5}$ & 100.0 & 100.0 & 100.0 & 6,322 & -14.6 \\
\hline
\end{tabular}

Source: Department of the Treasury. Office of Tax Analysis. March 8, 2001.

(11) The major individual income tax provisions are: i) lower individual income tax rates; ii) increase the child credit to $\$ 1,000$, raise the income level at which it phases out, and allow the child credit against the AMT; iii) allow a 10\% deduction for the earnings of the lower earning spouse (up to \$30,000) in two-earner families; iv) allow taxpayers who do not itemize to deduct charitable contributions up to the amount of the taxpayer's standard deduction; and v) provide a refundable tax credit for individually-purchased health insurance.

(12) Cash Income consists of wages and salaries, net income from a business or farm, taxable and tax-exempt interest, dividends, rental income, realized capital gains, cash transfers from the government, and retirement benefits. Employer contributions for payroll taxes and the federal corporate income tax are added to place cash on a pre-tax basis. Cash income is shown on a family rather than on a tax return basis. The cash incomes of all members of a family are added to arrive at a family's cash income used in the distributions.

(13) The refundable portions of the earned income tax credit (EITC) and the child credit are included in the individual income tax. Federal taxes are estimated at 2000 income levels but assuming fully phased in law and, therefore, exclude provisions that expire prior to the end of the Budget period and are adjusted for the effects of unindexed parameters.

(14) The change in Federal taxes is estimated at 2000 income levels assuming fully phased in law.

(15) Families with negative incomes are excluded from the lowest income class but included in the total line.

\begin{tabular}{|c|c|c|c|}
\hline $\begin{array}{l}\text { Tax Distribution Table Scoring Index (TDTSI) Analysis Tool for Revealing } \\
\text { Methodology, Content and Presentation in Tax Distribution Tables }\end{array}$ & $\begin{array}{l}\text { Yes - } \\
\text { Score } \\
\text { as “1" }\end{array}$ & $\begin{array}{l}\text { No- } \\
\text { Score } \\
\text { as “0” }\end{array}$ & $\begin{array}{l}\text { Can Not Be } \\
\text { Determined }\end{array}$ \\
\hline $\begin{array}{l}\text { 1. Is a measure of income used other than cash income or Adjusted Gross } \\
\text { Income (AGI)? }\end{array}$ & & 0 & \\
\hline 2. Is the unit of analysis families or households? & 1 & & \\
\hline 3. Is the percent change in after-tax income included in the analysis? & & 0 & \\
\hline 4. Is the percent of total tax change included in the analysis? & 1 & & \\
\hline 5. Are payroll taxes included in the analysis of taxes paid? & & 0 & \\
\hline 6. Is the number of taxpayers residing within the income categories omitted? & 1 & & \\
\hline 7. Are ranges of income associated with each income category omitted? & & 0 & \\
\hline 8. Are ranges of tax liability associated with each income category omitted? & 1 & & \\
\hline $\begin{array}{l}\text { 9. Are the current and proposed percent of total taxes paid for each income } \\
\text { category omitted? }\end{array}$ & & 0 & \\
\hline 10. Are the current and proposed tax rates for each income category omitted? & 1 & & \\
\hline
\end{tabular}

Table 7-10 produced by the OTA in 2001 under the Bush Administration takes a markedly different approach from the table produced by the 2000 OTA. Applying the TDTSI to the analysis of this table would provide affirmative responses for the following questions: 2, 4, 6, 8, and 10. Note that although employer contributions for payroll taxes are added to cash income to place cash on a pre-tax basis (footnote \#2 and relating to taxonomy question \#5), payroll taxes are not included in the analysis of taxes paid. 
Applying the first method of analysis to this OTA table simply summing the responses, indicates that the 2001 OTA table exhibits liberal characteristics in 5 out of 10 questions. However, it is hard to argue that the 2001 table, with a score of 5, is even close to being neutral just because some measures are omitted. The second approach yields a similar result: the table has leftleaning characteristics $5 / 10$ or $0.50(50 \%)$ and right-leaning characteristics $5 / 10$ or $0.50(50 \%)$, again indicating a balanced perspective. The third approach also results in a score that is balanced: zero [(5-5) / 10]. Since this value is zero, the results of the third method support the contention that the table is not designed to advance tax policy positions associated with liberal tax policy perspectives, or advance conservative tax policy perspectives.

The 2001 OTA table presents a completely different perspective than the table OTA released in 2000. The 2001 table is designed to promote tax legislation that provides tax relief and portrays the legislation in question as one that increases progressivity in the tax code. The perspective presented in the 2001 OTA table suggests that the tax plan in question would be progressive, and based on the percent change in individual income taxes, benefit lower-income groups. However, just because the TDTSI indicates the 2001 OTA table balances liberal and conservative perspectives, is the table actually balanced?

Regarding the 2001 OTA table, a former Clinton administration Treasury Deputy Assistant Secretary for Tax Analysis Len Burman writes "the presentation of the data and exclusion of certain information put the president's proposal in the best possible light and create a misleading impression of the distribution of benefits from the proposed tax cuts." ${ }^{\text {"131 }}$ Similar arguments were also made about misleading presentations of data when Burman was the official at Treasury responsible for overseeing distribution analysis. ${ }^{132}$

However, applying the TDTSI, readers of the 2001 OTA table would realize that the table is presented without five measures that are assumed to present a liberal perspective. If desired, readers of the 2001 OTA table could request that in order to gain additional perspectives, the table be re-released with the missing variables included. Hence, even if the TDTSI might indicate a table balances perspectives when some might consider it does not, the utility of the TDTSI is still evident as it allows users to identify missing variables that can have an impact on perspectives.

\footnotetext{
${ }^{131}$ Len Burman, “Treasury’s New Distribution Presentation,” Tax Notes (March 26, 2001.

132 See, for example: Jason Fichtner, “A Guide to Tax Policy Analysis: Problems with Distributional Tax Tables,” U.S. Congress, Joint Economic Committee (January 2000); “A Guide to Tax Policy Analysis: The Central Tendency of Federal Income Tax Liabilities in Distributional Analysis,” U.S. Congress, Joint Economic Committee (May 2000); “The Misleading Effects of Averages in Tax Distribution Analysis,” U.S. Congress, Joint Economic Committee (September 2003); and "A Comparison of Tax Distribution Tables: How Missing or Incomplete Information Distorts Perspectives,” U.S. Congress, Joint Economic Committee (December 2003).
} 
Table 7-11. Citizens for Tax Justice

\begin{tabular}{|c|c|c|c|c|c|c|c|c|c|}
\hline \multicolumn{10}{|c|}{$\begin{array}{l}\text { Effects of the Senate Finance Committee-passed version of the Bush tax plan } \\
\text { (Annual effects when fully in place, at } 2001 \text { income levels) }\end{array}$} \\
\hline Income Group & Income Range & $\begin{array}{l}\text { Average } \\
\text { Income }\end{array}$ & $\begin{array}{c}\text { Income } \\
\text { tax cuts } \\
\text { (\$-bill.) }\end{array}$ & $\begin{array}{c}\begin{array}{c}\text { Estate } \\
\text { tax } \\
\text { repeal }(\$ \\
\text { bill.) }\end{array} \\
\end{array}$ & $\begin{array}{c}\text { Total Tax } \\
\text { Cuts (\$- } \\
\text { bill.) }\end{array}$ & $\begin{array}{c}\text { Average } \\
\text { income tax } \\
\text { cuts }\end{array}$ & $\begin{array}{c}\text { Average } \\
\text { Total Tax } \\
\text { Cut }\end{array}$ & $\begin{array}{c}\% \text { of } \\
\text { income } \\
\text { tax cut }\end{array}$ & \begin{tabular}{|c}
$\%$ of Total \\
Tax Cut
\end{tabular} \\
\hline Lowest 20\% & Less than $\$ 15,000$ & $\$ 9,300$ & $\$-1.7$ & $\$-0.0$ & $\$-1.7$ & $\$-65$ & $\$-65$ & $1.3 \%$ & $1.0 \%$ \\
\hline Second $20 \%$ & $\$ 15,000-27,000$ & 20,600 & -9.5 & -0.0 & -9.5 & -363 & -364 & $7.3 \%$ & $5.7 \%$ \\
\hline Middle 20\% & $\$ 27,000-44,000$ & 34,400 & -14.6 & -0.0 & -14.6 & -562 & -562 & $11.3 \%$ & $8.9 \%$ \\
\hline Fourth $20 \%$ & $\$ 44,000-72,000$ & 56,400 & -24.2 & -0.0 & -24.2 & -931 & -931 & $18.7 \%$ & $14.7 \%$ \\
\hline Next $15 \%$ & $\$ 72,000-147,000$ & 97,400 & -40.8 & -0.0 & -40.8 & $-2,089$ & $-2,089$ & $31.4 \%$ & $24.8 \%$ \\
\hline Next 4\% & $\$ 147,000-373,000$ & 210,000 & -13.0 & -3.1 & -16.1 & $-2,500$ & $-3,100$ & $10.0 \%$ & $9.8 \%$ \\
\hline Top 1\% & $\$ 373,000$ or more & $1,117,000$ & -25.9 & -31.8 & -57.6 & $-19,892$ & $-44,293$ & $20.0 \%$ & $35.0 \%$ \\
\hline ALL & & $\$ 57,800$ & $\$-129.7$ & $\$-34.9$ & $\$-164.6$ & $\$-989$ & $\$-1,256$ & $100.0 \%$ & $100.0 \%$ \\
\hline \multicolumn{10}{|l|}{ ADDENDUM } \\
\hline Bottom $60 \%$ & Less than $\$ 44,000$ & $\$ 21,400$ & $\$-25.8$ & $\$-0.0$ & $\$-25.8$ & $\$-330$ & $\$-330$ & $19.9 \%$ & $15.7 \%$ \\
\hline Top 10\% & $\$ 104,000$ or more & 256,000 & -55.1 & -34.9 & -89.9 & $-4,231$ & $-6,912$ & $42.5 \%$ & $54.6 \%$ \\
\hline \multicolumn{10}{|c|}{$\begin{array}{l}\text { Notes: } 1 \text {. The table shows the annual effects of the tax cut plan approved by the Senate Finance Committee Chairman on May } 15,2001 \text {, fully-effective at } 2001 \text { income levels in } \\
2001 \text { dollars. Income tax cuts include: Reductions in the current } 28 \%, 31 \%, 36 \% \text {, and } 39.6 \% \text { rates to } 25 \%, 28 \%, 33 \% \text { and } 36 \% \text { (phased in by } 2007 \text { ). Addition of a new } 10 \% \\
\text { bracket on the first } \$ 12,000 \text { in taxable income for couples, } \$ 10,000 \text { for single parents, and } \$ 6,000 \text { for childless singles and married persons filing separately (unindexed until after } \\
\text { 2006). Increasing the starting point for the (new) } 25 \% \text { tax bracket for couples to double the starting point for childless single taxpayers (phased in by } 2010 \text { ). Increasing the } \\
\text { standard deduction for couples to double the childless single amount (phased in by } 2010 \text { ). Increasing the starting and ending points for the phase-out of the earned-income tax } \\
\text { credit for couples by } \$ 3,000 \text {. Doubling of the per-child credit to } \$ 1,000 \text { (phased in by } 2011 \text {, unindexed), with expanded rules for refundability of the credit. An increase in the } \\
\text { individual Alternative Minimum Tax exemption of } \$ 4,000 \text { for couples and } \$ 2,000 \text { for singles, from } 2002 \text { to } 2006 \text {. }\end{array}$} \\
\hline \multicolumn{10}{|c|}{$\begin{array}{l}\text { Repeal of the personal exemption phase out at high income levels (starting in 2009). An increase in the AGI starting points for the partial disallowance of itemized deductions at } \\
\text { high income levels, to the old levels for the phase-outs of personal exemptions (starting in 2009). A separate column shows the effects of repeal of the federal estate tax on large } \\
\text { estates. }\end{array}$} \\
\hline \multicolumn{10}{|c|}{$\begin{array}{l}\text { 2. The distributional effects of estate tax repeal are based on the approach outlined in Joint Committee on Taxation, Methodology and Issues in Measuring Changes in the } \\
\text { Distribution of Tax Burdens (1993). The figures do not take account of recent Joint Committee estimates that repeal could cost } 80 \text { percent more than previously estimated due to } \\
\text { income tax avoidance that repeal could engender (bringing the total cost of repeal to more than } \$ 100 \text { billion a year when fully phased in, in } 2011) \text {. The Senate bill may avoid } \\
\text { some of this added cost by retention of the federal gift tax, although it is unclear whether retaining only the gift tax is politically, practically or intellectually sustainable. }\end{array}$} \\
\hline
\end{tabular}

\begin{tabular}{|c|c|c|c|}
\hline $\begin{array}{l}\text { Tax Distribution Table Scoring Index (TDTSI) Analysis Tool for Revealing } \\
\text { Methodology, Content and Presentation in Tax Distribution Tables }\end{array}$ & $\begin{array}{l}\text { Yes - } \\
\text { Score } \\
\text { as “1" }\end{array}$ & $\begin{array}{l}\text { No- } \\
\text { Score } \\
\text { as “0" }\end{array}$ & $\begin{array}{l}\text { Can Not Be } \\
\text { Determined }\end{array}$ \\
\hline $\begin{array}{l}\text { 1. Is a measure of income used other than cash income or Adjusted Gross } \\
\text { Income (AGI)? }\end{array}$ & & & DK \\
\hline 2. Is the unit of analysis families or households? & & & DK \\
\hline 3. Is the percent change in after-tax income included in the analysis? & & 0 & \\
\hline 4. Is the percent of total tax change included in the analysis? & 1 & & \\
\hline 5. Are payroll taxes included in the analysis of taxes paid? & & & DK \\
\hline 6. Is the number of taxpayers residing within the income categories omitted? & 1 & & \\
\hline 7. Are ranges of income associated with each income category omitted? & & 0 & \\
\hline 8. Are ranges of tax liability associated with each income category omitted? & 1 & & \\
\hline $\begin{array}{l}\text { 9. Are the current and proposed percent of total taxes paid for each income } \\
\text { category omitted? }\end{array}$ & 1 & & \\
\hline 10. Are the current and proposed tax rates for each income category omitted? & 1 & & \\
\hline
\end{tabular}


Applying the three scoring methods of the TDTSI to this CTJ table give the following results. Note that were a question cannot be determined from the information presented in the table or footnotes, a Don't Know ("DK") is recorded. For purposes of the TDTSI, a "DK" is not counted in the scoring index. Therefore, using the first method of simply summing the responses, the CTJ table exhibits liberal characteristics in only 5 out of 7 questions, or $71 \%$. The second approach yields a result that indicates the table presents liberal characteristics $2 / 7$ or 0.29 (28.6\%) and right-leaning characteristics $2 / 7$ or 0.26 (28.6\%). The third approach also results in a score that labels the CTJ table as being left-leaning, with a score of 0.428 [(5 -2) / 7].

The table above by the Citizens for Tax Justice notice how the numbers for the columns titled "Average Total Tax Cut," and "\% of Total Tax Cut" are larger than the numbers for the rest of the table. Obviously, these two columns are the statistics that the CTJ wants to highlight as being the most important. Focusing primarily on the average tax cut amount and percent of total tax cut easily tilts in the direction of biasing any debate toward "class warfare" assertions. The design and presentation of data in this CTJ table do portray the liberal tax policy perspectives advocated by the CTJ, as discussed in the news articles previously.

By omitting variables which tend to present conservative policy perspectives from this table, such as percent of total taxes paid, the CTJ table is not attempting to portray the tax plan under a balanced perspective. End-users can apply the TDTSI to this CTJ table to request additional information in order to gain further insight into the CTJ analysis.

\section{Summary of TDTSI Results - Economic Growth and Tax Relief Reconciliation Act of 2001}

With respect to the Economic Growth and Tax Relief Reconciliation Act of 2001, the application of the TDTSI to tax distribution tables focusing on this bill is positive. The TDTSI was successful in identifying the overall right-leaning perspectives in the JCT table and successful at identifying the completely different perspectives between the Clinton OTA table and the Bush OTA table. The TDTSI also successfully identified the perspective of the CTJ table and even identified missing information from the table that could be useful in balancing perspectives. End-users of either the JCT or OTA table would be able to use the TDTSI to balance perspectives and, hopefully, gain a more balanced understanding of the distributional effects of Economic Growth and Tax Relief Reconciliation Act of 2001. 


\section{Jobs and Growth Tax Relief and Reconciliation Act of 2003 (JGTRRA 03)}

The Jobs and Growth Tax Relief and Reconciliation Act of 2003 was signed into law May 28, 2003. In one regard, GTRRA 03 was similar to another hallmark tax bill passed ten years prior, OBRA 93. As with OBRA 93 the Vice President cast the tie-breaking vote in the Senate, though a few members did cross the party isle in both chambers.

The main provisions of JGTRRA 03:

- created a top capital gains tax rate of $15 \%$, for lower incomes a $10 \%$ and $0 \%$ rate (thru 2008);

- $\quad$ accelerated the 2006 tax cuts from EGTTRA 01;

- accelerated marriage penalty relief provisions from EGTRRA 01 (through 2004);

- accelerated child tax credit increase to \$1,000 (thru 2004);

- lowered top individual income tax rate on dividends to $15 \%, 10 \%$ and $5 \%$ for lower incomes (thru 2008);

- accelerated expansion of $10 \%$ individual income tax rate bracket (thru 2004); and

- increased expensing for certain capital asset purchases to 50\% (thru 2004). ${ }^{133}$

Two articles published in The Washington Post set the stage for the perspectives that were being advanced by conservatives and liberals in the debate surrounding JGTRRA 03. In a December 16, 2002 article, The Post writes:

As the Bush administration draws up plans to simplify the tax system, it is also refining arguments for why it may be necessary to shift more of the tax load onto lower-income workers...Their efforts would thrust the administration into a debate that until now has lingered on the fringes of economic policy: Are too few wealthy Americans paying too much in taxes for too many, and should the working poor and middle class be shouldering more of the tax burden?

...Answering critics who say the working poor do face high taxes because they pay high Social Security payroll taxes, outgoing White House economic adviser Lawrence B. Lindsey told the AEI tax forum that the 12.4 percent Social Security levy should not be considered when tax burdens are calculated. Lindsey said the Social Security tax is ultimately returned to the taxpayer as a benefit.

..."If we take out Social Security, the poor will look very lightly taxed,” said Robert S. McIntyre of Citizens for Tax Justice, a tax research group backed by organized labor.

...But advocates of this new line can expect a furious backlash. Liberal commentators have already reduced the argument to an appeal to tax the poor, and

133 Jerry Tempalski, "Revenue Effects of Major Tax Bills," U.S. Department of the Treasury, Office of Tax Analysis, OTA Paper 81 (Revised July 2003). 
even conservatives worry that the label will stick. "It's hard to conclude it's anything else," said the Heritage Foundation's (Bill) Beach. ${ }^{134}$

A second article reports:

President Bush yesterday parried accusations that his tax cut proposal is unfairly tilted toward the wealthy as Democrats and some moderate Republicans voiced opposition.

...Yesterday's remarks plunged Bush into a growing argument about who benefits from the tax-cut proposal he introduced this week. Administration officials have been rebutting what they call "class warfare" accusations even before they released Bush's plan, although they acknowledged that the wealthiest Americans would receive the highest boost to their incomes from Bush's plan in both dollar and percentage terms.

A calculation of the effect of Bush's proposal by the Brookings Institution and the Urban Institute found that the top 1 percent of Americans, those with incomes of $\$ 374,000$ or more, would get 28.3 percent of Bush's tax cut, an average benefit of $\$ 24,428$, or a 3.5 percent increase in income.

...A calculation done by the liberal group Citizens for Tax Justice produced similar results, find that the top 10 percent of earners, those above $\$ 104,000$ in income, would get an average tax cut of $\$ 5,578$, or 60 percent of the total benefit...

...A senior Treasury Department official interviewed yesterday said it is true that wealthier Americans get a larger percentage increase in their after-tax incomes than those at the lower end of the scale. But he said they get a smaller percentage decrease in their taxes. As a result, Treasury figures show, the share of the tax burden borne by those earning more than $\$ 100,000$ would rise from 72.4 percent to 73.3 percent. $^{135}$

The newspaper article make clear the different perspectives advanced by liberals and conservatives: liberals focus on the average tax cut to portray the benefits of the tax plan as skewed toward the wealthy and not providing enough relief to lower-income groups, while conservatives portray the current tax system as one that is very progressive and overly taxing upper-income groups by focusing on percent of total taxes paid.

Did the distribution tables released advance these perspectives? The TDTSI is applied to four tables that were released analyzing JGTRRA 03 - one table by the Office of Tax Analysis, two tables produced by the Tax Policy Center, and one table by Citizens for Tax Justice. It should also be noted that the Joint Committee on Taxation stopped releasing distribution tables on major tax bills to the public by this time. ${ }^{136}$

\footnotetext{
134 Jonathan Weisman, “New Tax Plan May Bring Shift in Burden,” The Washington Post, December 16, 2002.

135 Dana Milbank and Chris Jenkins, “Bush Defends Tax Cut Proposal,” The Washington Post, January $10,2003$.

${ }^{136}$ Martin A. Sullivan, “The Decline and Fall of Distribution Analysis,” Tax Notes, June 30, 2003.
} 
Table 7-12. Office of Tax Analysis

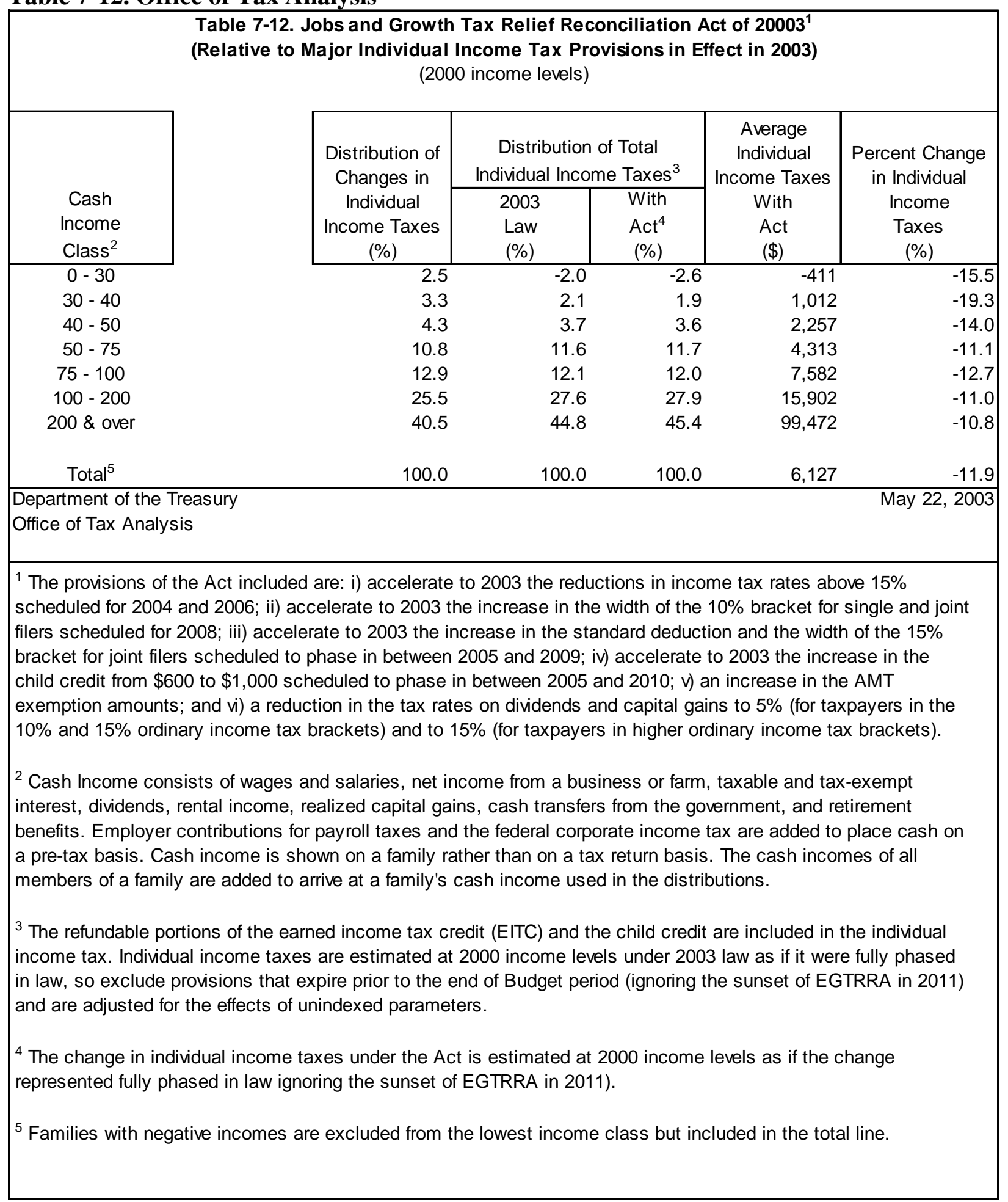




\begin{tabular}{|c|c|c|c|}
\hline $\begin{array}{c}\text { Tax Distribution Table Scoring Index (TDTSI) Analysis Tool for Revealing } \\
\text { Methodology, Content and Presentation in Tax Distribution Tables }\end{array}$ & $\begin{array}{l}\text { Yes - } \\
\text { Score } \\
\text { as "1" }\end{array}$ & $\begin{array}{l}\text { No- } \\
\text { Score } \\
\text { as "0" }\end{array}$ & $\begin{array}{l}\text { Can Not Be } \\
\text { Determined }\end{array}$ \\
\hline $\begin{array}{l}\text { 1. Is a measure of income used other than cash income or Adjusted Gross } \\
\text { Income (AGI)? }\end{array}$ & & 0 & \\
\hline 2. Is the unit of analysis families or households? & 1 & & \\
\hline 3. Is the percent change in after-tax income included in the analysis? & & 0 & \\
\hline 4. Is the percent of total tax change included in the analysis? & 1 & & \\
\hline 5. Are payroll taxes included in the analysis of taxes paid? & & 0 & \\
\hline 6. Is the number of taxpayers residing within the income categories omitted? & 1 & & \\
\hline 7. Are ranges of income associated with each income category omitted? & & 0 & \\
\hline 8. Are ranges of tax liability associated with each income category omitted? & 1 & & \\
\hline $\begin{array}{l}\text { 9. Are the current and proposed percent of total taxes paid for each income } \\
\text { category omitted? }\end{array}$ & & 0 & \\
\hline 10. Are the current and proposed tax rates for each income category omitted? & 1 & & \\
\hline
\end{tabular}

Applying the first method of analysis to this OTA table, simply summing the responses, indicates that this OTA table exhibits liberal characteristics in 5 out of 10 questions. The second approach yields a similar result: the table has left-leaning characteristics $5 / 10$ or $0.50(50 \%)$ and rightleaning characteristics $5 / 10$ or 0.50 (50\%), again indicating a balanced perspective. The third approach also results in a score that is balanced: zero [(5-5)/10]. Since this value is zero, the results of the third method support the contention that the table is not designed to advance tax policy positions associated with liberal tax policy perspectives, or advance conservative tax policy perspectives.

However, the presentation of data in this OTA table does support the perspectives being advanced by conservatives at this time, namely that higher-income groups are bearing a significant share of the total tax burden compared to lower-income groups. Notice that the data indicate that the income group with income less than \$30,000 actually receives a net transfer from the government. Not only are taxpayers in this income group not paying taxes, but they are getting a government transfer though social programs in the tax code such as the refundable portion of the Earned Income Tax Credit and the Child Tax Credit.

The flip-side to presenting data on average tax cut amount is presenting data on average amount of tax paid. The data in this OTA table indicate the amount of average tax paid, including negative amounts for the lower income groups. The purpose of presenting data in this manner is to blunt liberal criticism of a plan that gives higher average tax cuts to those in higher income groups by arguing that it is impossible to give a tax cut to those that do not pay taxes. 
Table 7-13. Tax Policy Center (\#1)

\begin{tabular}{|c|c|c|c|c|c|c|c|c|}
\hline 22-May-03 & $\begin{array}{c}\text { Preliminary } R \\
\text { Conferenc }\end{array}$ & $\begin{array}{r}\text { sults Based or } \\
\text { Agreement } \\
\text { Distribı }\end{array}$ & $\begin{array}{l}\text { Conference Re } \\
\text { on the Jobs a } \\
\text { ition of Incon }\end{array}$ & $\begin{array}{l}\text { ort (H. Rept. 108- } \\
\text { able T03-0107 } \\
\text { ad Growth Tax } \\
\text { Tax Change b }\end{array}$ & $\begin{array}{l}\text { 26) } \\
\text { Relief Reconc } \\
\text { AGI Class, } 2\end{array}$ & $\begin{array}{l}03^{1} \\
\text { iation Act of } \\
\end{array}$ & ttp://www.taxpc & icycenter.org \\
\hline $\begin{array}{c}\text { AGI Class } \\
\text { (thousands of } 2002\end{array}$ & & $\begin{array}{l}\text { Tax Units } \\
\text { Percent of }\end{array}$ & Percent with & $\begin{array}{c}\text { Percent Change } \\
\text { in After-Tax }\end{array}$ & $\begin{array}{c}\text { Percent of } \\
\text { Total Income }\end{array}$ & Average Tax & Average Inco & e Tax Rate $^{4}$ \\
\hline dollars) $^{2}$ & (thousands) & Total & Tax Cut & Income $^{3}$ & Tax Change & Change (\$) & Current Law & Proposal \\
\hline Less than 10 & 32,978 & 23.7 & 0.7 & * & * & -1 & -9.7 & -9.7 \\
\hline $10-20$ & 23,022 & 16.6 & 45.2 & 0.3 & 1.2 & -53 & -3.9 & -4.3 \\
\hline $20-30$ & 18,524 & 13.3 & 87.8 & 0.8 & 3.5 & -189 & 3.5 & 2.8 \\
\hline $30-40$ & 13,431 & 9.7 & 92.6 & 1.0 & 4.4 & -323 & 6.9 & 6.0 \\
\hline $40-50$ & 10,627 & 7.6 & 95.2 & 1.1 & 4.8 & -451 & 8.6 & 7.6 \\
\hline $50-75$ & 18,039 & 13.0 & 98.9 & 1.2 & 12.8 & -703 & 9.9 & 8.8 \\
\hline $75-100$ & 9,518 & 6.8 & 99.9 & 2.1 & 15.4 & $-1,611$ & 12.4 & 10.5 \\
\hline $100-200$ & 9,196 & 6.6 & 99.8 & 2.2 & 23.2 & $-2,506$ & 16.1 & 14.2 \\
\hline $200-500$ & 2,174 & 1.6 & 99.3 & 2.2 & 11.0 & $-5,015$ & 23.2 & 21.5 \\
\hline $500-1,000$ & 359 & 0.3 & 98.5 & 3.5 & 6.3 & $-17,307$ & 28.1 & 25.6 \\
\hline More than 1,000 & 184 & 0.1 & 98.7 & 4.4 & 17.3 & $-93,530$ & 29.2 & 26.0 \\
\hline All & 138,959 & 100.0 & 63.9 & 1.8 & 100.0 & -715 & 13.3 & 11.8 \\
\hline $\begin{array}{l}\text { Source: Urban-Brooki } \\
\text { * Less than } 0.05 \text { perce } \\
\text { (1) Calendar year. Bas } \\
\text { for singles and } \$ 14,00 \\
\text { couples to twice that } \mathrm{f} \\
\text { others; reduce the tax } \\
\text { be } 5 \text { percent; preferent } \\
\text { income from mutual fu } \\
\text { (2) Tax units with neg } \\
\text { (3) Includes both filing } \\
\text { (4) After-tax income is } \\
\text { (5) Average income ta }\end{array}$ & $\begin{array}{l}\text { Tax Policy CeI } \\
* * \text { Less than } \$ \\
\text { e is current lav } \\
\text { or married coup } \\
\text { ingles; reduce t } \\
\text { on qualifying } \\
\text { rates would not } \\
\text { s; lower capital } \\
\text { ve AGI are excl } \\
\text { id non-filing ur } \\
\text { GI less individı } \\
\text { let of refundabl }\end{array}$ & $\begin{array}{l}\text { er Microsimul } \\
\text { in absolute va } \\
\text { Includes the f } \\
\text { es; expand 15- } \\
\text { p four tax rate } \\
\text { vidends and l } \\
\text { apply to incom } \\
\text { ains rate appl } \\
\text { ded from the l } \\
\text { ts. Tax units t } \\
\text { l income tax n } \\
\text { credits, as a p }\end{array}$ & $\begin{array}{l}\text { ation Model (ver } \\
\text { lue. } \\
\text { ollowing provisi } \\
\text { percent bracket f } \\
\text { s to } 25,28,33 \text {, ar } \\
\text { ong-term capital } \\
\text { e that, under cur } \\
\text { y to qualifying as } \\
\text { owest income cla } \\
\text { hat are dependen } \\
\text { let of refundable } \\
\text { ercentage of aver }\end{array}$ & $\begin{array}{l}\text { on 0503-1). } \\
\text { s: increase child ta } \\
\text { married couples to } \\
35 \text { percent; increa } \\
\text { ains to } 15 \text { percent (t } \\
\text { et law, is reported } \\
\text { ets sold on or after } \\
\text { but are included in } \\
\text { of other taxpayers } \\
\text { gedits. } \\
\text { ge AGI. }\end{array}$ & $\begin{array}{l}\text { credit to } \$ 1,000 \\
\text { vice that for sin } \\
\text { AMT exemptio } \\
\text { rate for indivic } \\
\text { dividends on ta } \\
\text { y, 2003). } \\
\text { he totals. } \\
\text { e excluded fron }\end{array}$ & $\begin{array}{l}\text { xpand size of t } \\
\text { s; increase sta } \\
\text { } \$ 9,000 \text { for } ~ \\
\text { ls in the } 10 \text { an } \\
\text { eturns but rep } \\
\text { ee analysis. }\end{array}$ & $\begin{array}{l}\text { 10-percent brac } \\
\text { rd deduction fo } \\
\text { ied couples an } \\
\text { 5-percent tax b } \\
\text { nts distribution }\end{array}$ & $\begin{array}{l}\text { to } \$ 7,000 \\
\text { married } \\
\$ 4,500 \text { for } \\
\text { ckets would } \\
\text { of interest }\end{array}$ \\
\hline
\end{tabular}

\begin{tabular}{|c|c|c|c|}
\hline $\begin{array}{l}\text { Tax Distribution Table Scoring Index (TDTSI) Analysis Tool for Revealing } \\
\text { Methodology, Content and Presentation in Tax Distribution Tables }\end{array}$ & $\begin{array}{l}\text { Yes - } \\
\text { Score } \\
\text { as “1" }\end{array}$ & $\begin{array}{l}\text { No- } \\
\text { Score } \\
\text { as “0” }\end{array}$ & $\begin{array}{l}\text { Can Not Be } \\
\text { Determined }\end{array}$ \\
\hline $\begin{array}{l}\text { 1. Is a measure of income used other than cash income or Adjusted Gross } \\
\text { Income (AGI)? }\end{array}$ & & 0 & \\
\hline 2. Is the unit of analysis families or households? & & 0 & \\
\hline 3. Is the percent change in after-tax income included in the analysis? & 1 & & \\
\hline 4. Is the percent of total tax change included in the analysis? & 1 & & \\
\hline 5. Are payroll taxes included in the analysis of taxes paid? & 1 & & \\
\hline 6. Is the number of taxpayers residing within the income categories omitted? & & 0 & \\
\hline 7. Are ranges of income associated with each income category omitted? & & 0 & \\
\hline 8. Are ranges of tax liability associated with each income category omitted? & 1 & & \\
\hline $\begin{array}{l}\text { 9. Are the current and proposed percent of total taxes paid for each income } \\
\text { category omitted? }\end{array}$ & 1 & & \\
\hline 10. Are the current and proposed tax rates for each income category omitted? & & 0 & \\
\hline
\end{tabular}

Applying the first method of analysis to this TPC table, simply summing the responses, indicates that the table exhibits liberal characteristics in 5 out of 10 questions. The second approach yields a similar result: the table has left-leaning characteristics $5 / 10$ or 0.50 (50\%) and right-leaning characteristics $5 / 10$ or 0.50 (50\%), again indicating a balanced perspective. The third approach also results in a score that is balanced: zero [(5-5) / 10]. Since this value is zero, the results of the third method support the contention that the table is not designed to advance tax policy 
positions associated with liberal tax policy perspectives, or advance conservative tax policy perspectives.

However, the presentation of data in this TPC table does support the perspectives being advanced by liberals at this time, namely that a small number of high-income taxpayers are disproportionately benefiting from the tax plan. By presenting data on average tax cut amount and percent of taxpayers receiving a tax cut, the TPC table furthers liberal policy perspectives.

Interestingly, the TPC table does include the average income tax rate. Further, this measure is calculated net of refundable credits, showing that lower income groups effectively do not pay any taxes, which is a measure supportive of conservative tax policy perspectives.

\section{Table 7-14. Tax Policy Center (\#2)}

\begin{tabular}{|c|c|c|c|c|c|c|}
\hline 22-May-03 & \multicolumn{6}{|c|}{ Table T03-0108 } \\
\hline \multirow{2}{*}{ AGI Class ${ }^{2}$} & \multirow{2}{*}{$\begin{array}{c}\text { Percent of Tax } \\
\text { Units with Tax } \\
\text { Cut } \\
\end{array}$} & \multirow{2}{*}{$\begin{array}{c}\text { Percent Change } \\
\text { in After-Tax } \\
\text { Income }^{3} \\
\end{array}$} & \multirow{2}{*}{$\begin{array}{c}\text { Percent of } \\
\text { Total Income } \\
\text { Tax Change } \\
\end{array}$} & \multirow{2}{*}{$\begin{array}{c}\text { Average Tax } \\
\text { Change (\$) }\end{array}$} & \multicolumn{2}{|c|}{ Average Income Tax Rate ${ }^{4}$} \\
\hline & & & & & Current Law & Proposal \\
\hline Lowest Quintile & 0.1 & * & * & -1 & -10.1 & -10.2 \\
\hline Second Quintile & 34.4 & 0.3 & 1.1 & -38 & -4.9 & -5.2 \\
\hline Middle Quintile & 88.7 & 0.8 & 6.1 & -217 & 4.4 & 3.6 \\
\hline Fourth Quintile & 96.1 & 1.1 & 13.5 & -482 & 8.9 & 7.9 \\
\hline Next 10 Percent & 99.7 & 1.8 & 17.8 & $-1,270$ & 11.4 & 9.8 \\
\hline Next 5 Percent & 99.8 & 2.3 & 14.9 & $-2,125$ & 14.2 & 12.3 \\
\hline Next 4 Percent & 99.8 & 2.2 & 17.6 & $-3,145$ & 18.6 & 16.9 \\
\hline Top 1 Percent & 98.6 & 3.6 & 29.1 & $-20,786$ & 27.8 & 25.2 \\
\hline All & 63.9 & 1.8 & 100.0 & -715 & 13.3 & 11.8 \\
\hline \multicolumn{7}{|c|}{$\begin{array}{l}\text { Source: Urban-Brookings Tax Policy Center Microsimulation Model (version } 0503-1 \text { ). } \\
\text { * Less than } 0.05 \text { percent. ** Less than } \$ 1 \text { in absolute value. } \\
\text { (1) Calendar year. Baseline is current law. Includes the following provisions: increase child tax credit to } \$ 1,000 \text {; expand size of the } \\
10 \text {-percent bracket to } \$ 7,000 \text { for singles and } \$ 14,000 \text { for married couples; expand } 15 \text {-percent bracket for married couples to twice } \\
\text { that for singles; increase standard deduction for married couples to twice that for singles; reduce top four tax rates to } 25,28,33 \text {, } \\
\text { and } 35 \text { percent; increase AMT exemption by } \$ 9,000 \text { for married couples and } \$ 4,500 \text { for others; reduce the tax rate on qualifying } \\
\text { dividends and long-term capital gains to } 15 \text { percent (the rate for individuals in the } 10 \text { and } 15 \text {-percent tax brackets would be } 5 \\
\text { percent; preferential rates would not apply to income that, under current law, is reported as dividends on tax returns but represents } \\
\text { distributions of interest income from mutual funds; lower capital gains rates apply to qualifying assets sold on or after May } 6 \text {, } \\
\text { (2) Tax units with negative AGI are excluded from the lowest quintile but are included in the totals. Includes both filing and non- } \\
\text { filing units. Tax units that are dependents of other taxpayers are excluded from the analysis. } \\
\text { (3) After-tax income is AGI less individual income tax net of refundable credits. } \\
\text { (4) Average income tax, net of refundable credits, as a percentage of average AGI. }\end{array}$} \\
\hline
\end{tabular}




\begin{tabular}{|c|c|c|c|}
\hline $\begin{array}{l}\text { Tax Distribution Table Scoring Index (TDTSI) Analysis Tool for Revealing } \\
\text { Methodology, Content and Presentation in Tax Distribution Tables }\end{array}$ & $\begin{array}{l}\text { Yes- } \\
\text { Score } \\
\text { as “1” }\end{array}$ & $\begin{array}{l}\text { No- } \\
\text { Score } \\
\text { as “0” }\end{array}$ & $\begin{array}{l}\text { Can Not Be } \\
\text { Determined }\end{array}$ \\
\hline $\begin{array}{l}\text { 1. Is a measure of income used other than cash income or Adjusted Gross } \\
\text { Income (AGI)? }\end{array}$ & & 0 & \\
\hline 2. Is the unit of analysis families or households? & & 0 & \\
\hline 3. Is the percent change in after-tax income included in the analysis? & 1 & & \\
\hline 4. Is the percent of total tax change included in the analysis? & 1 & & \\
\hline 5. Are payroll taxes included in the analysis of taxes paid? & 1 & & \\
\hline 6. Is the number of taxpayers residing within the income categories omitted? & 1 & & \\
\hline 7. Are ranges of income associated with each income category omitted? & & 0 & \\
\hline 8. Are ranges of tax liability associated with each income category omitted? & 1 & & \\
\hline $\begin{array}{l}\text { 9. Are the current and proposed percent of total taxes paid for each income } \\
\text { category omitted? }\end{array}$ & 1 & & \\
\hline 10. Are the current and proposed tax rates for each income category omitted? & & 0 & \\
\hline
\end{tabular}

The second TPC table categories tax units by quintile, rather than income ranges. Applying the first method of analysis to this TPC table, simply summing the responses, indicates that the table exhibits liberal characteristics in 6 out of 10 questions. The second approach yields a similar result: the table has left-leaning characteristics $6 / 10$ or 0.60 (50\%) and right-leaning characteristics $4 / 10$ or 0.40 (40\%), indicating a slightly left-leaning perspective. The third approach also results in a score that is slightly left-leaning: .20 [(6-4) / 10].

Though mostly similar to the first TPC table, the presentation of data in this $2^{\text {nd }}$ TPC table is more supportive of the perspectives being advanced by liberals at this time, namely that a small number of high-income taxpayers are disproportionately benefiting from the tax plan. By presenting additional data on average tax cut amount and percent of taxpayers receiving a tax cut, the TPC table furthers liberal policy perspectives.

Again, as in the first TPC table, the $2^{\text {nd }}$ TPC table does include data for the average income tax rate. This measure is calculated net of refundable credits, showing that lower income groups effectively do not pay any taxes. This measure supports conservative tax policy perspectives.

The reason two different tables are provided by the Tax Policy Center is to demonstrate the necessity of applying the TSDI to multiple tables from the same organization. While application of the TDSI to some organizations can have consistent results, this is might not always be the case as is demonstrated in Tables 7-13 and 7-14. Further, with the TDTSI, end-users can balance perspectives by selecting multiple tables that have either opposite TDTSI scores or are "balanced" but as a result of focusing on different variables. 
Table 7-15 - Citizens for Tax Justice

\begin{tabular}{|c|c|c|c|c|c|c|c|c|c|c|}
\hline \multicolumn{11}{|c|}{ Effects of the House GOP 2003 Tax Cut Plan in 2003-06 } \\
\hline \multirow[b]{2}{*}{ Income Group } & \multicolumn{5}{|c|}{ Average Tax Cuts } & \multicolumn{5}{|c|}{ Shares of Tax Cuts } \\
\hline & 2003 & 2004 & 2005 & 2006 & $\begin{array}{c}\text { Four Year } \\
\text { Total }\end{array}$ & 2003 & 2004 & 2005 & 2006 & All Four \\
\hline Lowest 20\% & $\$-14$ & $\$-24$ & $\$-39$ & $\$-3$ & $\$-80$ & $0.3 \%$ & $0.4 \%$ & $0.5 \%$ & $0.2 \%$ & $0.4 \%$ \\
\hline Second $20 \%$ & -118 & -155 & -196 & -14 & -483 & $2.2 \%$ & $2.6 \%$ & $2.6 \%$ & $1.1 \%$ & $2.4 \%$ \\
\hline Middle 20\% & -324 & -405 & -474 & -42 & $-1,245$ & $6.1 \%$ & $6.7 \%$ & $6.4 \%$ & $3.4 \%$ & $6.2 \%$ \\
\hline Fourth $20 \%$ & -723 & -826 & -931 & -99 & $-2,578$ & $13.6 \%$ & $13.8 \%$ & $12.5 \%$ & $8.1 \%$ & $12.9 \%$ \\
\hline Next 15\% & $-1,994$ & $-2,169$ & $-2,505$ & -288 & $-6,955$ & $28.1 \%$ & $26.8 \%$ & $25.3 \%$ & $17.2 \%$ & $26.0 \%$ \\
\hline Next 4\% & $-4,761$ & $-5,351$ & $-7,231$ & $-1,183$ & $-18,526$ & $17.9 \%$ & $17.8 \%$ & $19.5 \%$ & $19.4 \%$ & $18.6 \%$ \\
\hline Top 1\% & $-33,954$ & $-38,152$ & $-49,175$ & $-12,275$ & $-133,557$ & $31.9 \%$ & $31.8 \%$ & $33.1 \%$ & $50.4 \%$ & $33.5 \%$ \\
\hline ALL & $\$-1,057$ & $-1,192$ & $\$-1,475$ & $\$-242$ & $\$-3,966$ & $100.0 \%$ & $100.0 \%$ & $100.0 \%$ & $100.0 \%$ & $100.0 \%$ \\
\hline ADDENDUM & & & & & & & & & & \\
\hline Bottom 60\% & $\$-152$ & $\$-195$ & $\$-236$ & $\$-19$ & $\$-603$ & $8.6 \%$ & $9.7 \%$ & $9.5 \%$ & $4.8 \%$ & $9.0 \%$ \\
\hline Top $10 \%$ & $-6,613$ & $-7,341$ & $-9,518$ & $-1,898$ & $-25,369$ & $62.1 \%$ & $61.1 \%$ & $64.0 \%$ & $78.0 \%$ & $63.5 \%$ \\
\hline
\end{tabular}

Figures include the effects of all of the provisions of the $\$ 550$ billion (over ten years) tax bill marked up by the House Ways and Means Committee on May 6, 2003, including the substantial reduction in corporate taxes (allocated by capital ownership). Years are calendar.

Source: Institute on Taxation and Economic Policy Tax Model, May 6, 2003.

Citizens for Tax Justice, May 6, 2003

\begin{tabular}{|c|c|c|c|}
\hline $\begin{array}{l}\text { Tax Distribution Table Scoring Index (TDTSI) Analysis Tool for Revealing } \\
\text { Methodology, Content and Presentation in Tax Distribution Tables }\end{array}$ & $\begin{array}{l}\text { Yes - } \\
\text { Score } \\
\text { as “1" }\end{array}$ & $\begin{array}{l}\text { No- } \\
\text { Score } \\
\text { as “0” }\end{array}$ & $\begin{array}{l}\text { Can Not Be } \\
\text { Determined }\end{array}$ \\
\hline $\begin{array}{l}\text { 1. Is a measure of income used other than cash income or Adjusted Gross } \\
\text { Income (AGI)? }\end{array}$ & & & DK \\
\hline 2. Is the unit of analysis families or households? & & & DK \\
\hline 3. Is the percent change in after-tax income included in the analysis? & & 0 & \\
\hline 4. Is the percent of total tax change included in the analysis? & 1 & & \\
\hline 5. Are payroll taxes included in the analysis of taxes paid? & & & DK \\
\hline 6. Is the number of taxpayers residing within the income categories omitted? & 1 & & \\
\hline 7. Are ranges of income associated with each income category omitted? & 1 & & \\
\hline 8. Are ranges of tax liability associated with each income category omitted? & 1 & & \\
\hline $\begin{array}{l}\text { 9. Are the current and proposed percent of total taxes paid for each income } \\
\text { category omitted? }\end{array}$ & 1 & & \\
\hline 10. Are the current and proposed tax rates for each income category omitted? & 1 & & \\
\hline
\end{tabular}

During the tax debates that culminated with the passage of JGTRRA 03, CTJ released numerous press releases containing tax distribution tables. These tables were often cited in major newspaper articles. Applying the three scoring methods of the TDTSI to this CTJ table give the following results. Note that were a question cannot be determined from the information presented in the table or footnotes, a Don't Know ("DK”) is recorded. Therefore, using the first method of simply summing the responses, the CTJ table exhibits liberal characteristics in 6 out of 7 questions, or $86 \%$. The second approach yields a result that indicates the table presents liberal characteristics $6 / 7$ or 0.857 (86\%) and right-leaning characteristics $1 / 7$ or 0.142 (14\%). The third approach also results in a score that is left-leaning with a score of 0.714 , or $71 \%$ [(6 - 
1) / 7]. These results are identical to the CTJ table analyzing the distributional effects of TRA 97 (Table 7-7).

The table above by the Citizens for Tax Justice easily tilts in the direction of biasing any debate toward class warfare assertions focusing only on which groups would get how much, while completely ignoring the distribution of the current tax burden. For example, as noted in a Tax Notes article:

The CTJ presentation easily lends itself to statements like the following: "Under the Bush plan, a millionaire would get a tax reduction that is a hundred times greater than the tax relief to the average middle-class family." And: "Under the Bush plan, the rich can buy a new Lexus, but a working-class family could barely afford a new muffler."137

The article further notes:

The problem with CTJ's analysis is not its economics, but its presentation. It provides no information about the distribution of taxes under current law. Therefore, it does not provide the necessary information for calculating the percentage changes in taxes caused by the Bush proposal. And so it is impossible to ascertain from the CTJ distribution tables whether the Bush proposal makes the tax system more progressive or less progressive, or whether the proposal is distributionally neutral. ${ }^{138}$

From the data in Table 7-15, the CTJ table clearly shows that upper income groups would receive a hefty tax break while the lower income groups get little.

The CTJ table fails to discuss or disclose the current distribution of taxes under current law. Further, CTJ fails to disclose in this table the income concept used in its analysis and whether families or tax returns are the unit of analysis. Although the CTJ table is categorized by quintiles or percentage groupings, since the total number of taxpayers is not presented, the number of taxpaying units per income class cannot be determined. There is also no disclosure on which existing taxes are included in the analysis (i.e., income, payroll, estate and gift, etc.)

\section{Summary of TDTSI Results - Jobs and Growth Tax Relief and Reconciliation Act of 2003}

The application of the TDTSI to tax distribution tables analyzing the distributional effects of the Jobs and Growth Tax Relief and Reconciliation Act of 2003 is very positive. The TDTSI effectively demonstrates that it can assist end-users of distribution tables in identifying presentations of data that are misleading or biased toward one perspective or another. The TDTSI was successful in identifying the overall right-leaning perspectives in the OTA table (under the authority of a Republican in the White House) and successful at identifying the balanced presentation of data in the TPC tables. End-users of either the OTA, TPC or CTJ tables

\footnotetext{
${ }^{137}$ Martin Sullivan, “Zen and the Art of Reading Distribution Tables,” Tax Notes, March 26, $2001,1751$.

${ }^{138}$ Ibid.
} 
would be able to use the TDTSI to balance perspectives and, if desired, request further information from the issuing group.

Further, with the TDTSI, end-users can balance perspectives by selecting multiple tables that have either opposite TDTSI scores or are "balanced" but as a result of focusing on different variables. For example, the TDTSI scored both the OTA table (Table 7-12) and the first TPC table (Table 7-13) as being balanced. But different and opposing perspectives were still being presented by these two tables. Armed with the knowledge illuminated by the TDTSI, an enduser of these two tables could effectively use both tables together to gain a balanced perspective of the distributional effects of JGTRRA 03, further demonstrating the utility of the TDTSI to policymakers and the public. 


\section{Working Families Tax Relief Act of 2004 (WFTRA 04)}

The Working Families Tax Relief Act of 2004 was signed into law on October 4, 2004, by President Bush...one month before the presidential election. The Republicans still controlled the White House and both chambers of Congress. WFTRA 04 extended certain provisions of JGTRRA 03. The major provisions of the bill include:

- an increase in the amount of the child tax credit to $\$ 1,000$ for tax years 2005 through 2009;

- an increase in the size of the 10 percent rate bracket to include incomes up to $\$ 7,000$ for single tax filers and \$14,000 for married couples filing jointly for tax years 2005 - 2008;

- additional marriage penalty relief;

- an increase in the Alternative Minimum Tax exemption amount to $\$ 42,250$ for single filers and \$58,000 for couples filing jointly; ${ }^{139}$

The Working Families Tax Relief Act of 2004 extended some of the popular provision of previous tax bills that were set to expire. The bill was signed into law only a month before the November 2004 election, with President Bush seeking a second term and the Republicans in both the House and Senate hoping to maintain power. The House was generally not considered to be in play, but the Democrats did have a chance to take back the Senate. In the end, Bush not only won the election but the Republicans increased their majority in both the Senate and the House.

Not many Members of Congress were willing to vote against a tax bill that reduces taxes one month away from an election. The bill passed in the House 339 to 65. In the Senate, the bill passed 92 to 3, with 5 Democratic Senators not voting. The vote margin is in stark contrast to the Jobs and Growth Tax Relief Reconciliation Act of 2003, which passed in the Senate by the tie-breaking vote of Vice President Cheney.

As reported in The Washington Times, "President Bush yesterday turned his focus to the economy, traveling to this battleground state to sign his fourth tax-relief package in four years." ${ }^{140}$ The Washington Post reported, "President Bush signed into law a fourth tax cut in less than four years, extending relief for married couples, parents and businesses during a well-timed ceremony..."141 Similar stories were reported in The USA Today, AP Newswire, and on television news shows such as CNN's Inside Politics, CBS Evening News, and NBC Evening News. ${ }^{142}$ Consideration of the tax bill was so close to the election, that its passage was never really in doubt. Congress was not going to let popular measures expire and be accused of "raising taxes" in an election year. Liberal groups opposed to extending the tax provisions released press reports denouncing the tax cuts, loss of revenue and state of the economy in general. ${ }^{143}$

\footnotetext{
${ }^{139}$ John K. Sweet, “JGTRRA Relief Extended,” Tax Notes, November 8, 2004.

140 Joseph Curl, "Bush Celebrates Tax-Relief Extension,” The Washington Times, October 5, 2004.

${ }^{141}$ Jim VandeHei, "Bush Enacts Fourth Tax Cut; Law Will Benefit Married Couples, Parents and Businesses,” The Washington Post, October 4, 2004.

142 “The Frontrunner," Bulletin News Network, October 5, 2004.

${ }^{143}$ See, for example: Robert Greenstein and Isaac Shapiro, "Many Middle-Class Families Likely to Wind up as Net Losers From the 'Middle-Class' Tax-Cut Legislation,” Center on Budget and Policy Priorities, September 28, 2004; and Jonathan Weisman, "Liberal Group Decries Corporate Tax Slide,” The Washington Post, September 23, 2004.
} 
Neither the Office of Tax Analysis nor the Joint Committee on Taxation publicly released a tax distribution table on the bill. Distribution tables were released by the Tax Policy Center, which at this point in time has apparently taken over producing distribution tables on behalf of liberalleaning advocacy groups, as even the Center on Budget and Policy Priorities now just includes TPC tables in their releases instead of doing their own table. ${ }^{144}$

The following two tables were both prepared and publicly released by the Tax Policy Center, which was the primary think-tank conducting distribution analysis. TPC tables also appeared, as mentioned, in other organizations’ press releases as well as in trade press articles. ${ }^{145}$

Table 7-16 - Tax Policy Center

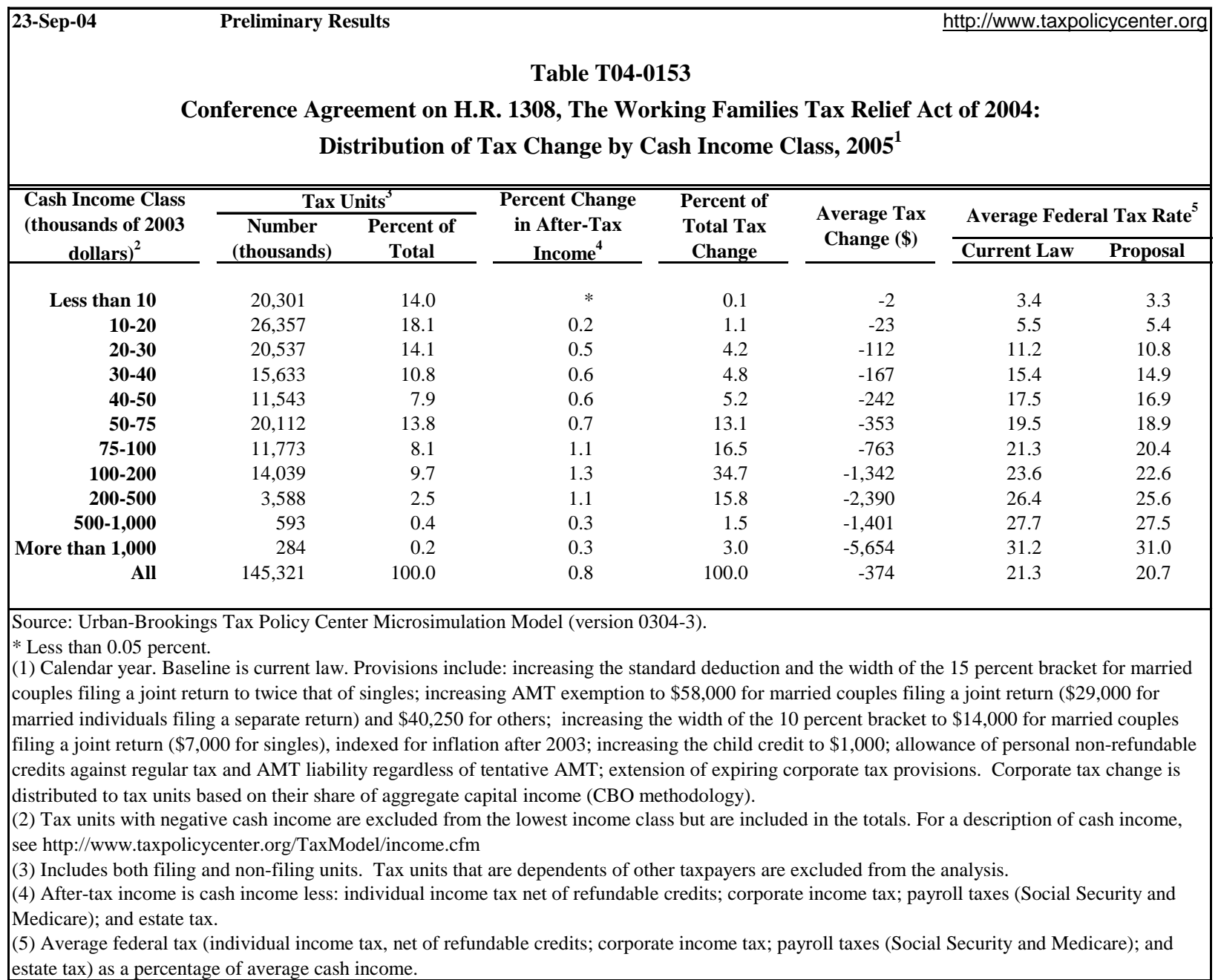

\footnotetext{
${ }^{144}$ See, for example, Robert Greenstein and Isaac Shapiro, "Many Middle-Class Families Likely to Wind up as Net Losers From the 'Middle-Class' Tax-Cut Legislation," Center on Budget and Policy Priorities, September 28, 2004. ${ }^{145}$ William G. Gale and Peter R. Orszag, “Should the President’s Tax Cuts Be Made Permanent?” Tax Notes, March 8, 2004.
} 


\begin{tabular}{|c|c|c|c|}
\hline $\begin{array}{l}\text { Tax Distribution Table Scoring Index (TDTSI) Analysis Tool for Revealing } \\
\text { Methodology, Content and Presentation in Tax Distribution Tables }\end{array}$ & $\begin{array}{l}\text { Yes - } \\
\text { Score } \\
\text { as “1" }\end{array}$ & $\begin{array}{l}\text { No- } \\
\text { Score } \\
\text { as “0" }\end{array}$ & $\begin{array}{l}\text { Can Not Be } \\
\text { Determined }\end{array}$ \\
\hline $\begin{array}{l}\text { 1. Is a measure of income used other than cash income or Adjusted Gross } \\
\text { Income (AGI)? }\end{array}$ & & 0 & \\
\hline 2. Is the unit of analysis families or households? & & 0 & \\
\hline 3. Is the percent change in after-tax income included in the analysis? & 1 & & \\
\hline 4. Is the percent of total tax change included in the analysis? & 1 & & \\
\hline 5. Are payroll taxes included in the analysis of taxes paid? & 1 & & \\
\hline 6. Is the number of taxpayers residing within the income categories omitted? & & 0 & \\
\hline 7. Are ranges of income associated with each income category omitted? & & 0 & \\
\hline 8. Are ranges of tax liability associated with each income category omitted? & 1 & & \\
\hline $\begin{array}{l}\text { 9. Are the current and proposed percent of total taxes paid for each income } \\
\text { category omitted? }\end{array}$ & 1 & & \\
\hline 10. Are the current and proposed tax rates for each income category omitted? & & 0 & \\
\hline
\end{tabular}

Applying the three scoring methods of the TDTSI to the TPC table give the following results. Using the first method of simply summing the responses, the TPC table exhibits liberal characteristics in 5 out of 10 questions, or $50 \%$. The second approach yields a result that indicates the table balances liberal and conservative perspectives $5 / 10$ or 0.50 (50\%) and rightleaning perspectives $5 / 10$ or 0.50 (50\%). The third approach also results in a score that is balanced with a score of zero [(5-5)/10].

The TPC table focuses on the percent change in after-tax income and average tax cut amount. However, by including data on the number of tax units per income category and average federal tax rate the table, according to the TDTSI, presents a perspective that is balanced between liberal and conservative characteristics. The TDTSI provides a different result for the next table, produced sequentially after Table 7-16. 
Table 7-17 - Tax Policy Center

\begin{tabular}{|c|c|c|c|c|c|}
\hline $\begin{array}{r}\text { 23-Sep-04 } \\
\text { Conference Agr } \\
\text { Distr }\end{array}$ & $\begin{array}{l}\text { ement on H.R. } \\
\text { bution of Tax }\end{array}$ & $\begin{array}{l}\text { Table T04 } \\
\text { 308, The W } \\
\text { ange by C }\end{array}$ & $\begin{array}{l}54 \\
\text { king Families } \\
\text { Income Perc }\end{array}$ & $\begin{array}{l}\text { Гax Relief Ac } \\
\text { ntiles, } 2005^{1}\end{array}$ & ycenter.org \\
\hline Casb Income Classe & $\begin{array}{l}\text { Percent Change } \\
\text { in After-Tax }\end{array}$ & $\begin{array}{l}\text { Percent of } \\
\text { Total Tax }\end{array}$ & Average Tax & Average Fede & I Tax Rate ${ }^{4}$ \\
\hline & Income $^{3}$ & Change & Change (\$) & Current Law & Proposal \\
\hline Lowest Quintile & * & 0.1 & -2 & 3.5 & 3.4 \\
\hline Second Quintile & 0.3 & 3.0 & -55 & 7.9 & 7.6 \\
\hline Middle Quintile & 0.6 & 8.7 & -162 & 14.7 & 14.2 \\
\hline Fourth Quintile & 0.7 & 17.7 & -331 & 19.2 & 18.6 \\
\hline Top Quintile & 1.0 & 70.5 & $-1,317$ & 25.3 & 24.5 \\
\hline All & 0.8 & 100.0 & -374 & 21.3 & 20.7 \\
\hline Addendum & & & & & \\
\hline Top 10 Percent & 0.9 & 46.8 & $-1,750$ & 26.6 & 25.9 \\
\hline Top 5 Percent & 0.8 & 29.0 & $-2,169$ & 27.7 & 27.1 \\
\hline Top 1 Percent & 0.3 & 6.4 & $-2,390$ & 29.5 & 29.3 \\
\hline Top 0.5 Percent & 0.3 & 4.1 & $-3,097$ & 30.2 & 30.0 \\
\hline Top 0.1 Percent & 0.3 & 2.4 & $-8,870$ & 31.8 & 31.6 \\
\hline $\begin{array}{l}\text { Source: Urban-Brookin } \\
\text { * Less than } 0.05 \text { percen } \\
\text { (1) Calendar year.Basel } \\
\text { the } 15 \text { percent bracket } \mathrm{f} \\
\text { to } \$ 58,000 \text { for married } \\
\$ 40,250 \text { for others; inc } \\
\text { return ( } \$ 7,000 \text { for singl } \\
\text { personal non-refundabl } \\
\text { expiring corporate tax p } \\
\text { capital income (CBO m } \\
\text { (2) Tax units with negat } \\
\text { Includes both filing and } \\
\text { analysis. For a descripti } \\
\text { (3) After-tax income is } \\
\text { payroll taxes (Social Se } \\
\text { (4) Average federal tax } \\
\text { (Social Security and Me }\end{array}$ & $\begin{array}{l}\text { Tax Policy Center } \\
\text { ee is current law. Pr } \\
\text { married couples fi } \\
\text { buples filing a joint } \\
\text { asing the width of t } \\
\text { ), indexed for infla } \\
\text { credits against regu } \\
\text { ovisions. Corporate } \\
\text { thodology). } \\
\text { ve cash income are } \\
\text { on-filing units. Tax } \\
\text { n of cash income, s } \\
\text { ash income less: inc } \\
\text { urity and Medicare) } \\
\text { individual income t } \\
\text { licare); and estate ta }\end{array}$ & $\begin{array}{l}\text { crosimulatio } \\
\text { sions include } \\
\text { a joint retul } \\
\text { In ( } \$ 29,000 \\
10 \text { percent b } \\
\text { after 2003; } \\
\text { ax and AM } \\
\text { change is d } \\
\text { luded from t } \\
\text { its that are d } \\
\text { ttp://www.to } \\
\text { lual income } \\
\text { d estate tax. } \\
\text { net of refund } \\
\text { as a percenta }\end{array}$ & $\begin{array}{l}\text { odel (version } 0 \\
\text { creasing the stan } \\
\text { twice that of si } \\
\text { married individ } \\
\text { et to } \$ 14,000 \text { fo } \\
\text { easing the child } \\
\text { bility regardless } \\
\text { buted to tax unit } \\
\text { west quintile bi } \\
\text { lents of other t } \\
\text { licycenter.org/T } \\
\text { et of refundabl }\end{array}$ & $\begin{array}{l}\text { 4-3). } \\
\text { rd deduction an } \\
\text { les; increasing A } \\
\text { s filing a separa } \\
\text { narried couples } \mathrm{f} \\
\text { edit to } \$ 1,000 \text {; a } \\
\text { tentative AMT; } \\
\text { ased on their sh } \\
\text { are included in tl } \\
\text { payers are exclu } \\
\text { Model/income.c } \\
\text { redits; corporate } \\
\text { income tax; pay }\end{array}$ & $\begin{array}{l}\text { he width of } \\
\text { T exemption } \\
\text { return) and } \\
\text { ng a joint } \\
\text { wance of } \\
\text { xtension of } \\
\text { of aggregate } \\
\text { totals. } \\
\text { d from the } \\
\text { tcome tax; } \\
\text { ll taxes }\end{array}$ \\
\hline
\end{tabular}


Jason J. Fichtner

\begin{tabular}{|c|c|c|c|}
\hline $\begin{array}{l}\text { Tax Distribution Table Scoring Index (TDTSI) Analysis Tool for Revealing } \\
\text { Methodology, Content and Presentation in Tax Distribution Tables }\end{array}$ & $\begin{array}{l}\text { Yes - } \\
\text { Score } \\
\text { as "1" }\end{array}$ & $\begin{array}{l}\text { No- } \\
\text { Score } \\
\text { as “0” }\end{array}$ & $\begin{array}{l}\text { Can Not Be } \\
\text { Determined }\end{array}$ \\
\hline $\begin{array}{l}\text { 1. Is a measure of income used other than cash income or Adjusted Gross } \\
\text { Income (AGI)? }\end{array}$ & & 0 & \\
\hline 2. Is the unit of analysis families or households? & & 0 & \\
\hline 3. Is the percent change in after-tax income included in the analysis? & 1 & & \\
\hline 4. Is the percent of total tax change included in the analysis? & 1 & & \\
\hline 5. Are payroll taxes included in the analysis of taxes paid? & 1 & & \\
\hline 6. Is the number of taxpayers residing within the income categories omitted? & 1 & & \\
\hline 7. Are ranges of income associated with each income category omitted? & 1 & & \\
\hline 8. Are ranges of tax liability associated with each income category omitted? & 1 & & \\
\hline $\begin{array}{l}\text { 9. Are the current and proposed percent of total taxes paid for each income } \\
\text { category omitted? }\end{array}$ & 1 & & \\
\hline 10. Are the current and proposed tax rates for each income category $\mathrm{c}$ & & 0 & \\
\hline
\end{tabular}

Table 7-17 is the next tax distribution table produced by the TPC. The main difference between this table and the previous one is the income category. Table 7-16 categorizes tax units into dollar income ranges, while Table 7-17 uses quintiles. Presumable, the TPC left out data relating to the number of tax units per income group since an end-user could calculate this figure using the previous table. However, if an end-user only had access to Table 7-17, they would only know that the quintiles contain equal unit amounts but not know the exact number. An end-user also would not know how many tax units were in the top 10 percent, top 5 percent, etc. Also not shown is the income ranges or dollar cut-off points for the quintiles.

If these two variables had been included in this table, Table 7-17 would have a TDTSI score equal to the score for Table 7-16. However, these variables are not included so the score indicates the table is liberal-leaning. Applying the three scoring methods of the TDTSI to the second TPC table give the following results. Using the first method of simply summing the responses, the TPC table exhibits liberal characteristics in 7 out of 10 questions, or $70 \%$. The

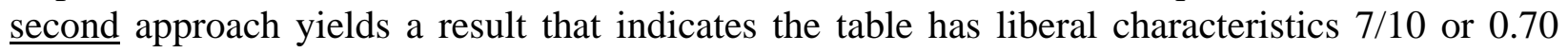
(70\%) and right-leaning perspectives $3 / 10$ or 0.30 (30\%). The third approach also results in a score that is left-leaning with a score of .40 [(7-3) / 10].

\section{Summary of TDTSI Results - Working Families Tax Relief Act of 2004}

The application of the TDTSI to tax distribution tables related to the Working Families Tax Relief Act of 2004 is mostly positive. The TDTSI again effectively demonstrates that it can assist end-users of distribution tables in identifying presentations of data that are misleading or biased toward one perspective or another. The TDTSI was successful in identifying the overall balanced approach that the Tax Policy Center applies to the presentation of data in its tax distribution tables. Though the average tax cut and percent of tax change is the primary focus of the TPC analysis, and tax share information is excluded, which presents information in a liberal perspective, the table does provide before and after tax rate information, which presents a conservative perspective. Applying the TDTSI to TPC distribution tables still reveals certain variables that are missing from the analysis. End-users, if they desired further information, would know which additional data to request based on the TDTSI. 


\section{Miscellaneous Tax Distribution Tables}

The following distribution tables are not related to any specific tax legislation. Occasionally, groups release distribution tables that analyze the current distribution of federal tax burdens or take an aggregated look at the distribution of benefits from previous legislation. These tables are generally released to educate and inform on the current state of the tax system and contribute to the debate on tax policy. But do these tables present a balanced perspective? Or do the tables portray biased and misleading information that sometimes accompanies tax distribution tables focuses on specific tax legislation?

The TDTSI is applied to three tables that focus on the general distribution of tax burden. The first table by the Joint Committee on Taxation. The second table by the Center on Budget and Policy Priorities, based on Congressional Budget Office Data. The third was prepared by the Tax Policy Center.

Table 7-18. Joint Committee on Taxation

\begin{tabular}{|c|c|c|c|c|c|c|c|c|}
\hline \multicolumn{9}{|c|}{ DISTRIBUTION OF FEDERAL INDIVIDUAL INCOME TAX LIABILITY (1) } \\
\hline \multirow[t]{2}{*}{$\begin{array}{l}\text { INCOME } \\
\text { CATEGORY (2) }\end{array}$} & \multicolumn{2}{|c|}{$\begin{array}{l}\text { NUMBER OF } \\
\text { RETURNS (3) }\end{array}$} & \multicolumn{2}{|c|}{ INCOME } & \multicolumn{2}{|c|}{$\begin{array}{l}\text { INDIVIDUAL } \\
\text { INCOME TAX }\end{array}$} & \multicolumn{2}{|c|}{$\begin{array}{c}\text { NUMBER OF RETURNS } \\
\text { WITH ZERO OR } \\
\text { NEGATIVE LIABILITY }\end{array}$} \\
\hline & Millions & Percent & Billions & Percent & Billions & Percent & Millions & Percent \\
\hline Less than $\$ 10,000 \ldots \ldots \ldots \ldots$ & 19.9 & $14.0 \%$ & $\$ 83$ & $1.0 \%$ & $-\$ 6$ & $-0.7 \%$ & 18.9 & $37.4 \%$ \\
\hline 10,000 to $20,000 \ldots \ldots .$. & 23.3 & $16.4 \%$ & 347 & $4.2 \%$ & -13 & $-1.3 \%$ & 16.4 & $32.4 \%$ \\
\hline 20,000 to $30,000 \ldots \ldots \ldots \ldots . . . . . .$. & 18.5 & $13.0 \%$ & 460 & $5.6 \%$ & 3 & $0.4 \%$ & 8.5 & $16.9 \%$ \\
\hline 30,000 to $40,000 \ldots \ldots$. & 15.8 & $11.1 \%$ & 549 & $6.7 \%$ & 22 & $2.4 \%$ & 3.8 & $7.5 \%$ \\
\hline 40,000 to $50,000 \ldots \ldots \ldots \ldots$ & 13.1 & $9.2 \%$ & 589 & $7.2 \%$ & 33 & $3.5 \%$ & 1.8 & $3.7 \%$ \\
\hline 50,000 to $75,000 \ldots \ldots \ldots \ldots$ & 21.9 & $15.4 \%$ & 1,337 & $16.4 \%$ & 100 & $10.6 \%$ & 1.0 & $2.0 \%$ \\
\hline 75,000 to $100,000 \ldots \ldots \ldots \ldots$ & 12.9 & $9.1 \%$ & 1,121 & $13.7 \%$ & 110 & $11.6 \%$ & 0.1 & $0.2 \%$ \\
\hline 100,000 to $200,000 \ldots \ldots \ldots \ldots$ & 12.8 & $9.0 \%$ & 1,683 & $20.6 \%$ & 226 & $23.9 \%$ & (4) & $0.1 \%$ \\
\hline 200,000 and over................ & 3.8 & $2.7 \%$ & 1,999 & $24.5 \%$ & 471 & $49.7 \%$ & (4) & (5) \\
\hline Total, All Taxpayers..... & 142.0 & $100.0 \%$ & $\$ 8,168$ & $100.0 \%$ & $\$ 948$ & $100.0 \%$ & 50.6 & $100.0 \%$ \\
\hline Highest 10\%............ & 14.2 & $10.0 \%$ & 3,431 & $42.0 \%$ & 670 & $70.7 \%$ & (4) & $0.1 \%$ \\
\hline Highest $5 \% \ldots \ldots \ldots \ldots$ & 7.1 & $5.0 \%$ & 2,556 & $31.3 \%$ & 559 & $59.0 \%$ & (4) & (5) \\
\hline Highest $1 \% \ldots \ldots \ldots \ldots$ & 1.4 & $1.0 \%$ & 1,402 & $17.2 \%$ & 357 & $37.6 \%$ & (4) & (5) \\
\hline \multicolumn{9}{|c|}{$\begin{array}{l}\text { Source: Joint Committee on Taxation } \\
\text { Detail may not add to total due to rounding }\end{array}$} \\
\hline \multicolumn{9}{|c|}{$\begin{array}{l}\text { (1) Includes the outlay portion of the EIC and child credit. } \\
\text { (2) The income concept used to place tax returns into income categories is adjusted gross income (AGI) plus: [1] tax-exempt } \\
\text { interest, [2] employer contributions for health plans and life insurance, [3] employer share of FICA tax, [4] workers' compensation, } \\
\text { [5] nontaxable Social Security benefits, [6] insurance value of Medicare benefits [7] alternative minimum tax preference items, and } \\
\text { [8] excluded income of U.S. citizens living abroad. Categories are measured at } 2001 \text { levels. } \\
\text { The highest } 10 \% \text { begins at } \$ 107,455, \text { the highest } 5 \% \text { at } \$ 145,1999 \text { and the highest } 1 \% \text { at } \$ 340,306 \\
\text { (3) Includes filing and nonfiling units. Individuals who are dependents of other taxpayers and taxpayers with negative income are } \\
\text { excluded. } \\
\text { (4) Less than } 50,000 . \\
\text { (5) Less than } 0.005 \% \text {. }\end{array}$} \\
\hline
\end{tabular}


Jason J. Fichtner

\begin{tabular}{|c|c|c|c|}
\hline $\begin{array}{l}\text { Tax Distribution Table Scoring Index (TDTSI) Analysis Tool for Revealing } \\
\text { Methodology, Content and Presentation in Tax Distribution Tables }\end{array}$ & $\begin{array}{l}\text { Yes - } \\
\text { Score } \\
\text { as "1" }\end{array}$ & $\begin{array}{l}\text { No- } \\
\text { Score } \\
\text { as "0" }\end{array}$ & $\begin{array}{l}\text { Can Not Be } \\
\text { Determined }\end{array}$ \\
\hline $\begin{array}{l}\text { 1. Is a measure of income used other than cash income or Adjusted Gross } \\
\text { Income (AGI)? }\end{array}$ & & 0 & \\
\hline 2. Is the unit of analysis families or households? & & 0 & \\
\hline 3. Is the percent change in after-tax income included in the analysis? & & 0 & \\
\hline 4. Is the percent of total tax change included in the analysis? & & 0 & \\
\hline 5. Are payroll taxes included in the analysis of taxes paid? & & 0 & \\
\hline 6. Is the number of taxpayers residing within the income categories omitted? & & 0 & \\
\hline 7. Are ranges of income associated with each income category omitted? & & 0 & \\
\hline 8. Are ranges of tax liability associated with each income category omitted? & 1 & & \\
\hline $\begin{array}{l}\text { 9. Are the current and proposed percent of total taxes paid for each income } \\
\text { category omitted? }\end{array}$ & & 0 & \\
\hline 10. Are the current and proposed tax rates for each income category omitted & 1 & & \\
\hline
\end{tabular}

Since the table is not analyzing changes as a result of proposed tax legislation, some leeway has to be allowed for questions \#3, \#4, \#9, and \#10. Instead of requiring the variables in question measure changes in value, the TDTSI can be used to simply to account for whether or not the base variable is included. For example, Question \#9 seeks to reveal if the table presents the share of total taxes paid by each income group before and after a tax change. Since this table is not focusing on tax changes, but does include a measure for presenting the share of total taxes paid under the current income tax system, it is counted as not being omitted from the table.

Therefore, applying the three scoring methods of the TDTSI to this JCT give the following results. Using the first method of simply summing the responses, the JCT table exhibits liberal characteristics in 2 out of 10 questions, or 20\%. The second approach yields a result that indicates the table has liberal characteristics $2 / 10$ or $0.20(20 \%)$ and right-leaning perspectives $7 / 10$ or $0.70(70 \%)$. The third approach also results in a score that is right-leaning with a score of negative $.80[(2-10) / 10]$.

This JCT table is close to being scored as a perfectly leaning conservative-leaning table by the TDTSI. By focusing on the percent of total individual income taxes paid by each income group, and including additional information on the number of tax returns that have zero or negative tax liability, this JCT table portrays the current distribution of the tax burden as very progressive. This viewpoint supports conservative tax policy perspectives.

It should be noted that this table was released in August 2001, with a Republican in the White House and Republicans in control of the House of Representatives, but right after the historic change of power in the Senate from Republican control to Democratic control as a result of Senator Jeffords (see discussion related to Economic Growth and Tax Relief Reconciliation Act of 2001). 
Table 7-19. Center on Budget and Policy Priorities

\begin{tabular}{|c|c|c|c|c|}
\hline \multicolumn{5}{|c|}{$\begin{array}{l}\text { Who Benefits?: Distribution of Bush Administration Tax Cuts in } 2004 \\
\text { (excluding the effects of the corporate and estate tax cuts) }\end{array}$} \\
\hline & $\begin{array}{l}\text { Average } \\
\text { Income }\end{array}$ & $\begin{array}{l}\text { Average } \\
\text { Tax Cut }\end{array}$ & $\begin{array}{l}\text { Share of the } \\
\text { Tax Cut }\end{array}$ & $\begin{array}{l}\text { Percentage Change in } \\
\text { After-Tax Income }\end{array}$ \\
\hline Lowest 20 percent & 16,600 & -230 & $2.8 \%$ & $1.5 \%$ \\
\hline Second 20 percent & 38,100 & -720 & $8.3 \%$ & $2.2 \%$ \\
\hline Middle 20 percent & 57,400 & -980 & $11.5 \%$ & $2.0 \%$ \\
\hline Fourth 20 percent & 84,300 & $-1,520$ & $17.7 \%$ & $2.3 \%$ \\
\hline Top 20 percent & 203,700 & $-4,890$ & $59.9 \%$ & $3.3 \%$ \\
\hline$\overline{\text { All }}$ & 80,100 & $-1,680$ & $1 \overline{00.0 \%}$ & $\overline{2.7 \%}$ \\
\hline 81-90 percent & 116,600 & $-2,210$ & $13.4 \%$ & $2.5 \%$ \\
\hline 91-95 percent & 155,000 & $-3,180$ & $9.8 \%$ & $2.7 \%$ \\
\hline 96-99 percent & 243,100 & $-4,830$ & $12.0 \%$ & $2.8 \%$ \\
\hline Top one percent & $1,171,000$ & $-40,990$ & $24.6 \%$ & $5.3 \%$ \\
\hline
\end{tabular}

\begin{tabular}{|c|c|c|c|}
\hline $\begin{array}{l}\text { Tax Distribution Table Scoring Index (TDTSI) Analysis Tool for Revealing } \\
\text { Methodology, Content and Presentation in Tax Distribution Tables }\end{array}$ & $\begin{array}{l}\text { Yes - } \\
\text { Score } \\
\text { as “1" }\end{array}$ & $\begin{array}{l}\text { No- } \\
\text { Score } \\
\text { as “0" }\end{array}$ & $\begin{array}{l}\text { Can Not Be } \\
\text { Determined }\end{array}$ \\
\hline $\begin{array}{l}\text { 1. Is a measure of income used other than cash income or Adjusted Gross } \\
\text { Income (AGI)? }\end{array}$ & & & DK \\
\hline 2. Is the unit of analysis families or households? & & & DK \\
\hline 3. Is the percent change in after-tax income included in the analysis? & 1 & & \\
\hline 4. Is the percent of total tax change included in the analysis? & 1 & & \\
\hline 5. Are payroll taxes included in the analysis of taxes paid? & & & DK \\
\hline 6. Is the number of taxpayers residing within the income categories omitted? & 1 & & \\
\hline 7. Are ranges of income associated with each income category omitted? & 1 & & \\
\hline 8. Are ranges of tax liability associated with each income category omitted? & 1 & & \\
\hline $\begin{array}{l}\text { 9. Are the current and proposed percent of total taxes paid for each income } \\
\text { category omitted? }\end{array}$ & 1 & & \\
\hline 10. Are the current and proposed tax rates for each income category omitted? & 1 & & \\
\hline
\end{tabular}

Again, as with the previous table, since the CBPP table is not analyzing changes as a result of proposed tax legislation, some leeway has to be allowed for questions \#3, \#4, \#9, and \#10. Also, the raw data was not created by CBPP, but by the Congressional Budget Office. However, CBPP analysts chose to present certain CBO data and in a specific presentation.

Therefore, applying the three scoring methods of the TDTSI to this CBPP give the following results. Using the first method of simply summing the responses, the CBPP table exhibits liberal characteristics in 7 out of 7 questions, or $100 \%$. The second approach yields a result that indicates the table has liberal characteristics $7 / 7$ or $0.70(70 \%)$ and right-leaning perspectives $0 / 7$ or $0.00(0 \%)$. The third approach also results in a score that is perfectly left-leaning with a score of $1.0[(7-0) / 7]$.

As mentioned, the CBPP table is based on CBO data. It might be possible to assume that CBO data was originally based on of a family unit of analysis and used an adjusted family income 
measure. If so, then the CBPP table would have scored two more items as liberal-leaning and kept the overall perspective of the table the same.

This CBPP table is scored as a perfectly left-leaning table by the TDTSI. By focusing on the share of total tax cut, percent change in after-tax income, and including average tax cut amount for good-measure, this table is void of any conservative perspectives and is completely unbalanced. This table supports the viewpoint of liberal tax policy perspectives by portraying the distribution of tax cuts has overly benefiting the wealthy.

Table 7-20. Tax Policy Center

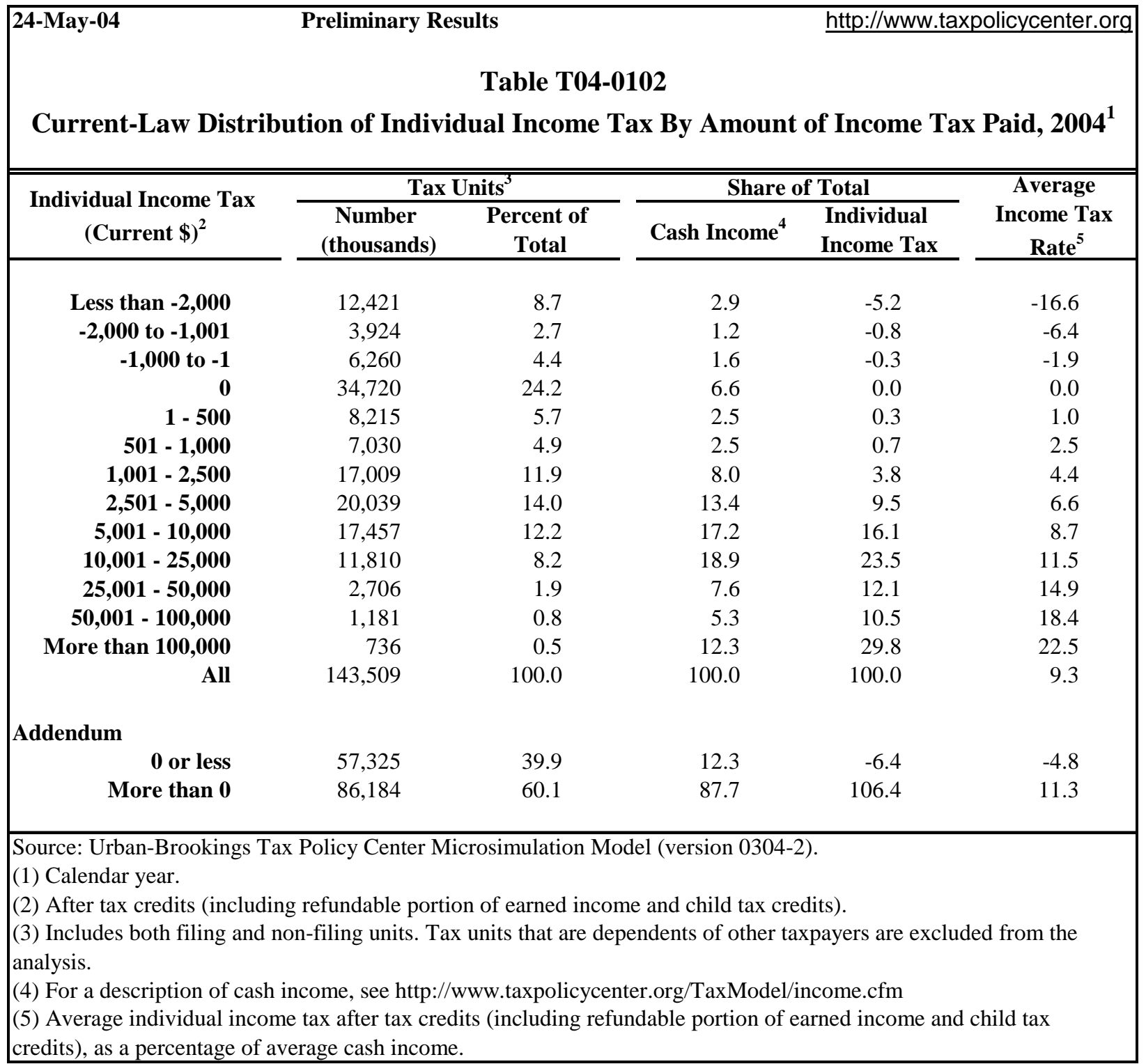




\begin{tabular}{|c|c|c|c|}
\hline $\begin{array}{l}\text { Tax Distribution Table Scoring Index (TDTSI) Analysis Tool for Revealing } \\
\text { Methodology, Content and Presentation in Tax Distribution Tables }\end{array}$ & $\begin{array}{l}\text { Yes - } \\
\text { Score } \\
\text { as “1" }\end{array}$ & $\begin{array}{l}\text { No- } \\
\text { Score } \\
\text { as “0" }\end{array}$ & $\begin{array}{l}\text { Can Not Be } \\
\text { Determined }\end{array}$ \\
\hline $\begin{array}{l}\text { 1. Is a measure of income used other than cash income or Adjusted Gross } \\
\text { Income (AGI)? }\end{array}$ & & 0 & \\
\hline 2. Is the unit of analysis families or households? & & 0 & \\
\hline 3. Is the percent change in after-tax income included in the analysis? & & 0 & \\
\hline 4. Is the percent of total tax change included in the analysis? & 1 & & \\
\hline 5. Are payroll taxes included in the analysis of taxes paid? & & & DK \\
\hline 6. Is the number of taxpayers residing within the income categories omitted? & & 0 & \\
\hline 7. Are ranges of income associated with each income category omitted? & & 0 & \\
\hline 8. Are ranges of tax liability associated with each income category omitted? & 1 & & \\
\hline $\begin{array}{l}\text { 9. Are the current and proposed percent of total taxes paid for each income } \\
\text { category omitted? }\end{array}$ & & 0 & \\
\hline 10. Are the current and proposed tax rates for each income category omitted? & & 0 & \\
\hline
\end{tabular}

Applying the three scoring methods of the TDTSI to the TPC table give the following results. Using the first method of simply summing the responses, the TPC table exhibits liberal characteristics in 2 out of 9 questions, or $22 \%$. The second approach yields a result that indicates the table has left-leaning perspectives $2 / 9$ or 0.222 (22\%) and right-leaning perspectives $7 / 9$ or 0.777 (78\%). The third approach also results in a score that is right-leaning with a score of negative .555 [(2-7) / 9].

The TPC table focuses on the share of total income and total taxes paid by each income group. Presented in this manner, the TPC table does not advance liberal policy perspectives. If fact, the TPC table presents conservative-leaning perspectives by showing that lower-income groups have negative tax rates and, therefore, receive a net transfer from the government.

\section{Summary of TDTSI Results - Miscellaneous Tax Distribution Tables}

The TDTSI effectively identified the information presented in the CBPP table as being biased toward liberal policy perspectives, consistent with the CBPP as an organization. Further, the TDTSI also identified which missing information could be presented to provide a balanced analysis.

Interestingly, the TDTSI identified the TPC table as having a right-leaning bias. Does this suggest that the Tax Policy Center has conservative tax policy preferences? Or does it suggest that the TPC attempts to balance its presentation of data by releasing many tax distribution tables which, when combined, present a balanced perspective? Unfortunately, the TSDI does not reveal answers to such questions. 


\section{Tax Distribution Tables Where the TDTSI Fails}

During the research process, the TDTSI failed to identify correctly the overall liberal or conservative perspective of a small number of tax distribution tables. These tables had one common trait; the primary focus was on how many tax units (returns, families, etc.) did not receive a tax benefit as a result of a plan to cut taxes with very little additional information provided.

Below are two examples of tax distribution tables where the TDTSI failed to accurately identify the policy leaning perspectives presented in the analysis. The first is a Citizens for Tax Justice table, the second a Tax Policy Center table.

\section{Table 7-21. Citizens for Tax Justice}

\begin{tabular}{|c|c|c|c|c|c|c|c|}
\hline \multicolumn{8}{|c|}{$\begin{array}{l}\text { Number of Taxpayers With Little or No Income Tax Cut } \\
\text { Under George W. Bush's Tax Plan } \\
\text { (Numbers of taxpayers in thousands) }\end{array}$} \\
\hline Income Group & $\begin{array}{l}\text { Number of } \\
\text { tax units }\end{array}$ & Income Range & $\begin{array}{l}\text { Average } \\
\text { Income }\end{array}$ & $\begin{array}{l}\text { \# with No } \\
\text { Tax Cut }\end{array}$ & $\%$ & $\begin{array}{l}\# \text { with Less } \\
\text { Than } \$ 1,600 \\
\text { Tax Cut }\end{array}$ & $\%$ \\
\hline Lowest 20\% & 25,323 & Less than $\$ 13,600$ & $\$ 8,600$ & 18,945 & $74.8 \%$ & 25,323 & $100.0 \%$ \\
\hline Second $20 \%$ & 25,324 & $\$ 13,600-24,400$ & 18,800 & 9,341 & $36.9 \%$ & 25,324 & $100.0 \%$ \\
\hline Middle 20\% & 25,325 & $\$ 24,400-39,300$ & 31,100 & 3,267 & $12.9 \%$ & 24,906 & $98.3 \%$ \\
\hline Fourth $20 \%$ & 25,326 & $\$ 39,300-64,900$ & 50,700 & 663 & $2.6 \%$ & 23,160 & $91.4 \%$ \\
\hline Next $15 \%$ & 18,994 & $\$ 64,900-130,000$ & 86,800 & 641 & $3.4 \%$ & 11,591 & $61.0 \%$ \\
\hline Next $4 \%$ & 5,065 & $\$ 130,000-319,000$ & 183,000 & 559 & $11.0 \%$ & 2,689 & $53.1 \%$ \\
\hline Top 1\% & 1,264 & $\$ 319,000$ or more & 915,000 & 144 & $11.4 \%$ & 358 & $28.3 \%$ \\
\hline ALL & 127,585 & & $\$ 50,800$ & 34,526 & $27.1 \%$ & 114,315 & $89.6 \%$ \\
\hline \begin{tabular}{|l|} 
ADDENDUM \\
Bottom $60 \%$
\end{tabular} & 75,972 & Less than $\$ 39,300$ & $\$ 19,500$ & 31,553 & $41.5 \%$ & 75,553 & $99.4 \%$ \\
\hline Top 10\% & 12,660 & $\$ 92,500$ or more & 218,000 & 945 & $7.5 \%$ & 5,432 & $42.9 \%$ \\
\hline
\end{tabular}

\begin{tabular}{|c|c|c|c|}
\hline $\begin{array}{l}\text { Tax Distribution Table Scoring Index (TDTSI) Analysis Tool for Revealing } \\
\text { Methodology, Content and Presentation in Tax Distribution Tables }\end{array}$ & $\begin{array}{c}\text { Yes - } \\
\text { Score } \\
\text { as “1" }\end{array}$ & $\begin{array}{c}\text { No- } \\
\text { Score } \\
\text { as “0” }\end{array}$ & $\begin{array}{l}\text { Can Not Be } \\
\text { Determined }\end{array}$ \\
\hline $\begin{array}{l}\text { 1. Is a measure of income used other than cash income or Adjusted Gross } \\
\text { Income (AGI)? }\end{array}$ & & & DK \\
\hline 2. Is the unit of analysis families or households? & & 0 & \\
\hline 3. Is the percent change in after-tax income included in the analysis? & & 0 & \\
\hline 4. Is the percent of total tax change included in the analysis? & & 0 & \\
\hline 5. Are payroll taxes included in the analysis of taxes paid? & & & DK \\
\hline 6. Is the number of taxpayers residing within the income categories omitted? & & 0 & \\
\hline 7. Are ranges of income associated with each income category omitted? & & 0 & \\
\hline 8. Are ranges of tax liability associated with each income category omitted? & 1 & & \\
\hline $\begin{array}{l}\text { 9. Are the current and proposed percent of total taxes paid for each income } \\
\text { category omitted? }\end{array}$ & 1 & & \\
\hline 10. Are the current and proposed tax rates for each income category omitted? & 1 & & \\
\hline
\end{tabular}


During the tax debates that culminated with the passage of EGTRRA 01, CTJ released numerous press releases containing tax distribution tables. However, like Table 7-21 and Tables 7-4 and 77 before, most showed only a few selected variables and little supporting information was provided. This table was chosen for analysis to apply an extreme test to the TDTSI. Can the TDTSI effectively evaluate a table by a left-leaning organization that is presenting information on the number of taxpayers that would receive no tax cut?

Applying the three scoring methods of the TDTSI to this CTJ table give the following results. Note that were a question cannot be determined from the information presented in the table or footnotes, a Don't Know ("DK") is recorded. For purposes of the TDTSI, a "DK" is not counted in the scoring index. Therefore, using the first method of simply summing the responses, the CTJ table exhibits liberal characteristics in only 3 out of 8 questions, or $37.5 \%$. The second approach yields a result that indicates the table presents liberal characteristics $3 / 8$ or 0.375 (37.5\%) and right-leaning characteristics $5 / 8$ or 0.625 (62.5\%). The third approach also results in a score that incorrectly labels the CTJ table as being right-leaning, with a score of negative $0.25[(3-5) / 8]$.

The table above by the Citizens for Tax Justice easily tilts in the direction of biasing any debate toward "class warfare" assertions by focusing only on how many taxpayers in each income group allegedly would receive no tax cut under the tax plan. By omitting variables which tend to present liberal policy perspectives from this table, such as percent of total tax cut, share of total taxes paid, the TDTSI scores this table as presenting an overall perspective that is conservativeleaning. However, this CTJ table is not attempting to portray the tax plan under conservative perspectives. 
Table 7-22. Tax Policy Center

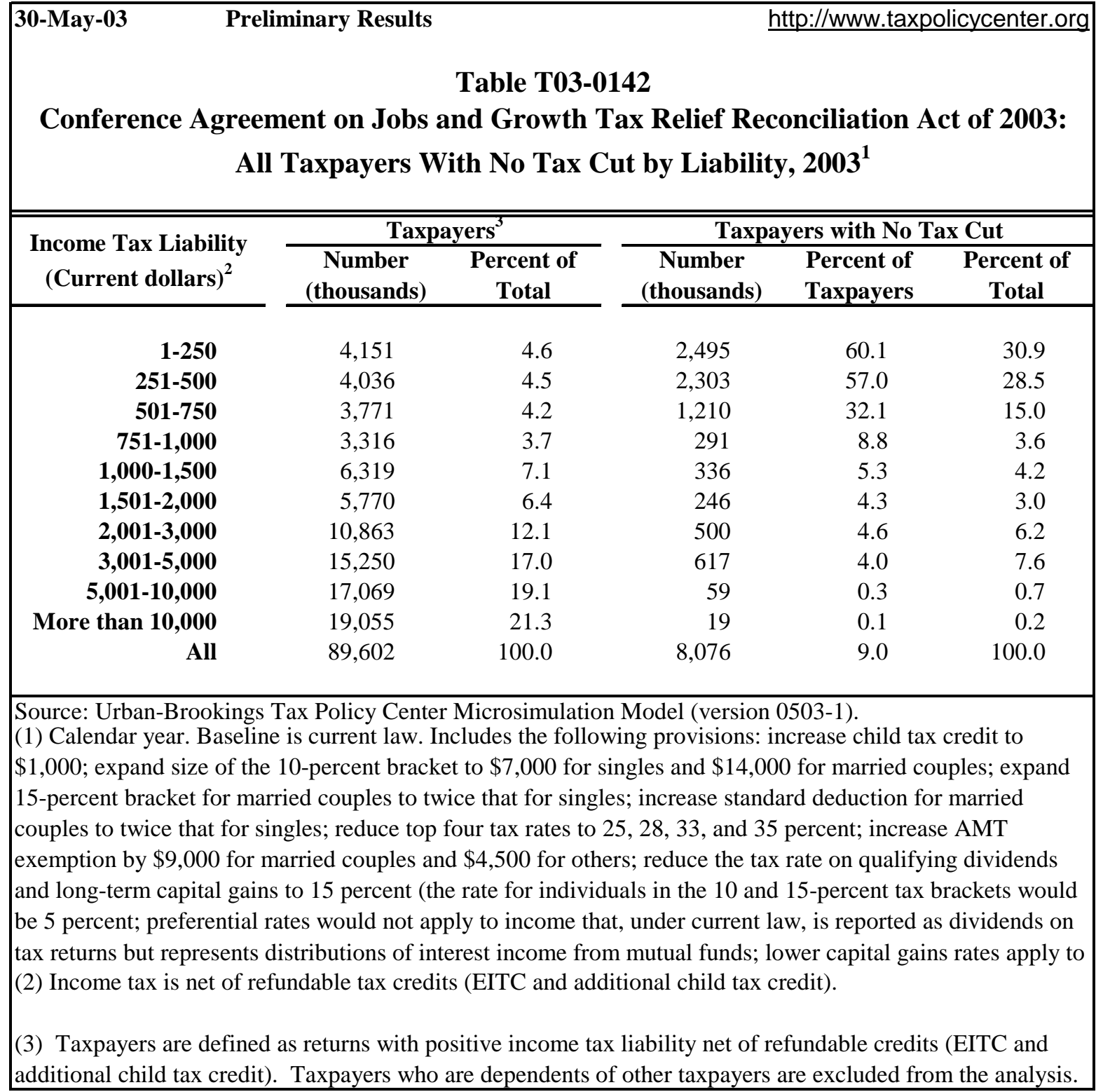




\begin{tabular}{|c|c|c|c|}
\hline $\begin{array}{l}\text { Tax Distribution Table Scoring Index (TDTSI) Analysis Tool for Revealing } \\
\text { Methodology, Content and Presentation in Tax Distribution Tables }\end{array}$ & $\begin{array}{l}\text { Yes - } \\
\text { Score } \\
\text { as "1" }\end{array}$ & $\begin{array}{l}\text { No- } \\
\text { Score } \\
\text { as “0” }\end{array}$ & $\begin{array}{l}\text { Can Not Be } \\
\text { Determined }\end{array}$ \\
\hline $\begin{array}{l}\text { 1. Is a measure of income used other than cash income or Adjusted Gross } \\
\text { Income (AGI)? }\end{array}$ & & 0 & \\
\hline 2. Is the unit of analysis families or households? & & 0 & \\
\hline 3. Is the percent change in after-tax income included in the analysis? & & 0 & \\
\hline 4. Is the percent of total tax change included in the analysis? & & 0 & \\
\hline 5. Are payroll taxes included in the analysis of taxes paid? & & & DK \\
\hline 6. Is the number of taxpayers residing within the income categories omitted? & & 0 & \\
\hline 7. Are ranges of income associated with each income category omitted? & 1 & & \\
\hline 8. Are ranges of tax liability associated with each income category omitted? & & 0 & \\
\hline $\begin{array}{l}\text { 9. Are the current and proposed percent of total taxes paid for each income } \\
\text { category omitted? }\end{array}$ & 1 & & \\
\hline 10. Are the current and proposed tax rates for each income category omitted? & 1 & & \\
\hline
\end{tabular}

Applying the TDTSI to this TPC table using the first method, simply summing the responses, the TPC table exhibits liberal characteristics in only 3 out of 9 questions, or 33.3\%. The second approach yields a result that indicates the table presents liberal characteristics 3/9 or 0.333 (33\%) and right-leaning characteristics $6 / 9$ or 0.666 (67\%). The third approach also results in a score that labels the TPC table as right-leaning, with a score of negative 0.333 [(3-9 )/9].

This TPC table is the only table analyzed to present ranges of tax liability. However, previous TPC tables have presented data indicating that the lowest income groups have a negative tax liability. In this table, the least amount of tax is $\$ 1$. It should be a negative amount, since the footnote says the data are net of refundable credits. This omission is misleading. Unfortunately, the TDTSI does not account for this type of "missing” information.

The TPC table, similar to the Citizens for Tax Justice table previously, easily tilts in the direction of biasing any debate toward "class warfare" assertions focusing only on how a large number of taxpayers in lower-income group would receive no tax cut under the tax plan. By omitting variables which tend to present liberal policy perspectives from this table, such as percent of total tax cut and change in after-tax income, the TDTSI scores this table as presenting an overall perspective that is conservative-leaning. However, this TPC table is not attempting to portray the conference agreement under conservative perspectives.

\section{Summary of TDTSI Results - Tax Distribution Tables Where the TDTSI Fails}

While the TDTSI failed to accurately identify the policy perspective portrayed by the CTJ and TPC tables in this section of the analysis, one positive note to take away from this example is that the TDTSI still effectively identifies some of the variables that would portray a conservative perspective as missing. End-users can still apply the TDTSI to both the CTJ and TPC tables to request additional information in order to gain further insight into the analyses. 
Jason J. Fichtner

\section{Summary of Results - The Tax Distribution Table Scoring Index as a Tool of Policy Analysis to Evaluate Policy Perspectives in Tax Distribution Tables}

This chapter has demonstrated that the Tax Distribution Table Scoring Index can be an effective tool for identifying the potentially biased and misleading data this is included (omitted) in tax distribution tables. For the most part, the TDTSI was able to accurately identify the general policy perspective (liberal or conservative) portrayed. More importantly, the TDTSI successfully identified data that are missing from the analyses and which are required in order to provide an end-user with balanced perspectives. The ability to reveal misleading and biased presentations of data and identify data needed in order to provide balanced perspectives is the main utility of the TDTSI to policymakers and the public.

Table 7-23 provides a summary of the TDTSI results from each tax distribution tabled evaluated in this dissertation.

\begin{tabular}{|c|c|c|c|c|c|c|c|c|c|c|c|c|c|c|c|c|}
\hline & & & & $\begin{array}{r}\text { rable } 7 \\
\text { Re }\end{array}$ & $\begin{array}{l}23-\mathrm{S} \\
\text { sults (1 }\end{array}$ & $\begin{array}{l}\text { Immar } \\
\text { As app }\end{array}$ & $\begin{array}{l}y \text { of Tax } \\
\text { lied to } E\end{array}$ & $\begin{array}{l}\text { istrib } \\
\text { ch tab }\end{array}$ & $\begin{array}{l}\text { oution T } \\
\text { ole in th }\end{array}$ & $\begin{array}{l}\text { Table S } \\
\text { ee diss }\end{array}$ & $\begin{array}{l}\text { oring Index } \\
\text { tation) }\end{array}$ & & & & & \\
\hline & Q.1 & Q.2 & Q.3 & $\begin{array}{llll} & 0.4 \\
\end{array}$ & Q.5 & Q.6 & Q.7 & Q.8 & Q.9 & Q.10 & $\begin{array}{l}\text { Total Liberal } \\
\text { Perspectives }\end{array}$ & $\begin{array}{c}\text { Total } \\
\text { Conservative } \\
\text { Perspectives }\end{array}$ & $\begin{array}{c}\text { Total Don't } \\
\text { Know }\end{array}$ & White House & Senate & House \\
\hline \begin{tabular}{|l|} 
Table 6-1 \\
Table 6-2 \\
\end{tabular} & $\frac{1}{0}$ & $\frac{1}{1}$ & $\frac{1}{0}$ & \begin{tabular}{|l|}
1 \\
1
\end{tabular} & $\frac{1}{0}$ & $\begin{array}{l}0 \\
1\end{array}$ & \begin{tabular}{|l|}
1 \\
0 \\
\end{tabular} & $\frac{1}{1}$ & \begin{tabular}{|l|}
1 \\
0
\end{tabular} & $\frac{1}{1}$ & $\frac{9}{5}$ & 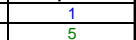 & $\frac{0}{0}$ & $\begin{array}{l}\text { Dem } \\
\text { Rep }\end{array}$ & $\begin{array}{l}\text { Rep } \\
\text { Rep }\end{array}$ & $\begin{array}{l}\text { Rep } \\
\text { Rep }\end{array}$ \\
\hline Table 7-1 & R & 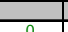 & ( & 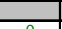 & ? & 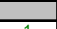 & & 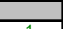 & 5 & 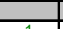 & 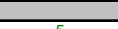 & & & & 2 & \\
\hline $\begin{array}{l}\text { Table } 1-1 \\
\text { Table 7-2 }\end{array}$ & 1 & 1 & 0 & 0 & $\frac{1}{1}$ & $\frac{1}{1}$ & $\begin{array}{l}0 \\
0\end{array}$ & $\frac{1}{1}$ & \begin{tabular}{|l|}
1 \\
0
\end{tabular} & $\frac{1}{1}$ & $\frac{5}{7}$ & $\frac{5}{3}$ & 0 & $\frac{\mathrm{Dem}}{\mathrm{Dem}}$ & $\frac{\mathrm{Dem}}{\mathrm{Dem}}$ & $\frac{\mathrm{Dem}}{\mathrm{Dem}}$ \\
\hline \begin{tabular}{|l|} 
Table 7-3 \\
Tel
\end{tabular} & 1 & 1 & 1 & 1 & 1 & 1 & 1 & 1 & 1 & \begin{tabular}{|l|l} 
\\
0
\end{tabular} & 9 & 1 & 0 & Dem & Dem & Dem \\
\hline \begin{tabular}{|l|} 
Table 7 7-4 \\
Table 7-5
\end{tabular} & DK & 1 & 1 & 1 & DK & 1 & 0 & 1 & 1 & \begin{tabular}{|l}
1 \\
\end{tabular} & 7 & $\frac{1}{7}$ & 2 & Dem & Dem & Dem \\
\hline \begin{tabular}{|l|} 
Table 7-5 \\
Table 7-
\end{tabular} & $\begin{array}{l}0 \\
1\end{array}$ & $\begin{array}{l}0 \\
1\end{array}$ & $\begin{array}{l}0 \\
1\end{array}$ & $\begin{array}{l}0 \\
1\end{array}$ & $\begin{array}{l}1 \\
1\end{array}$ & $\frac{1}{0}$ & 0 & $\begin{array}{l}1 \\
1\end{array}$ & $\frac{0}{1}$ & $\frac{0}{1}$ & $\frac{3}{8}$ & $\frac{7}{2}$ & $\frac{0}{0}$ & $\frac{\text { Dem }}{\text { Dem }}$ & $\begin{array}{l}\text { Rep } \\
\text { Rep }\end{array}$ & $\begin{array}{l}\text { Rep } \\
\text { Rep }\end{array}$ \\
\hline Table 7-7 & DK & DK & 0 & 1 & DK & 1 & 1 & 1 & 1 & 1 & $\frac{6}{6}$ & & 3 & Dem & Rep & $\frac{\text { Rep }}{\text { Ren }}$ \\
\hline Table 7-8 & 0 & & & & 1 & 1 & 0 & 1 & 0 & $=0$ & & 7 & & & & Rep \\
\hline \begin{tabular}{|l} 
Table 7-9 \\
\end{tabular} & 1 & 1 & 1 & 1 & 1 & 0 & 1 & 1 & 1 & 1 & 9 & 1 & 0 & Dem & Rep & Rep \\
\hline Table 7-10 & 0 & 1 & 0 & 1 & 0 & 1 & 0 & 1 & 0 & 1 & 5 & 5 & 0 & Rep & Rep & Rep \\
\hline Table 7-11 & DK & $\mathrm{DK}$ & 0 & 1 & $\mathrm{DK}$ & 1 & 0 & 1 & 1 & 1 & 5 & & - & Rep & Rep & Rep \\
\hline Table 7-12 & 0 & 1 & 0 & 1 & 0 & 1 & 0 & 1 & 0 & 1 & 5 & 5 & 0 & Rep & Rep & Rep \\
\hline$\frac{\text { Table 7-13 }}{\text { Table 7-13 }}$ & 0 & 0 & 1 & 1 & 1 & 0 & 0 & 1 & 1 & \begin{tabular}{|l}
0 \\
\end{tabular} & 5 & 5 & 0 & $\frac{\text { Rep }}{R e n}$ & Rep & Rep \\
\hline Table 7-15 & DK & DK & $\frac{1}{0}$ & $\begin{array}{l}1 \\
1 \\
\end{array}$ & 1 & 1 & 1 & $\begin{array}{l}1 \\
1 \\
\end{array}$ & $\frac{1}{1}$ & \begin{tabular}{|l} 
\\
1
\end{tabular} & $\frac{6}{6}$ & $\frac{4}{1}$ & 3 & $\frac{\text { Rep }}{\text { Rep }}$ & $\begin{array}{l}\text { Rep } \\
\text { Rep }\end{array}$ & \begin{tabular}{|l|} 
Rep \\
Rep
\end{tabular} \\
\hline \begin{tabular}{|l|l|l|} 
Table 7-16 \\
\end{tabular} & 0 & 0 & 1 & 1 & 1 & 0 & 0 & 1 & 1 & 0 & 5 & 5 & S & Rep & Ren & Rep \\
\hline \begin{tabular}{|l|} 
Table 7-17 \\
\end{tabular} & 0 & 0 & 1 & 1 & 1 & 1 & 1 & 1 & 1 & \begin{tabular}{|l} 
\\
1
\end{tabular} & 7 & 3 & 0 & Rep & Rep & Rep \\
\hline \begin{tabular}{|l|l|l|l|} 
Table 7-18 \\
Table
\end{tabular} & $\frac{O}{D K}$ & $\frac{O}{D K}$ & $\frac{0}{1}$ & $\begin{array}{l}0 \\
1\end{array}$ & 0 & 0 & 0 & 1 & 0 & \begin{tabular}{|l}
1 \\
\end{tabular} & 8 & $\frac{8}{0}$ & $\frac{0}{2}$ & $\frac{\text { Rep }}{\text { Ren }}$ & $\frac{\text { Dem }}{\text { Rep }}$ & $\frac{\text { Rep }}{\text { Rep }}$ \\
\hline Table 7-20 & $\frac{2 \pi}{0}$ & $\mathrm{Ln}_{0}$ & 0 & 1 & $\frac{1 K}{D K}$ & $\frac{1}{0}$ & $\frac{1}{0}$ & 1 & $\frac{1}{0}$ & 10 & $\frac{3}{2}$ & & & 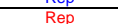 & Rep & 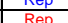 \\
\hline Table 7-21 & $\mathrm{DK}$ & 0 & 0 & & $\mathrm{DK}$ & 0 & 0 & 1 & 1 & 1 & & & & Rep & Rep & Rep \\
\hline Table 7-22 & 0 & 0 & 0 & 0 & DK & 0 & 1 & 10 & $\frac{1}{1}$ & \begin{tabular}{|l}
1 \\
\end{tabular} & & 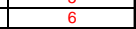 & 1 & Rep & Rep & Rep \\
\hline Summary Statistics & & & & & & & & & & & & & & & & \\
\hline & Q.1 & Q.2 & Q.3 & Q.4 & Q.5 & Q.6 & Q.7 & Q.8 & Q.9 & Q.10 & & & & & & \\
\hline Total Liberal P & & 7 & & 15 & 12 & 14 & & 21 & 15 & 14 & & Total \# Tab & fft-Lean & & 11 & \\
\hline erspectives & 12 & 11 & 12 & 7 & 3 & 8 & 15 & 1 & 7 & 8 & & Total \# Tables R & gight-Leaning. & & ${ }^{6}$ & \\
\hline Total Don't Know & 6 & 4 & 0 & 0 & 7 & 0 & 0 & 0 & 0 & 0 & & Total \# of Tables & Balanced..... & & & \\
\hline 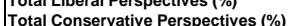 & $\begin{array}{l}18.2 \% \\
54.5 \%\end{array}$ & $50.0 \%$ & $\begin{array}{l}45.5 \% \\
5.5 \%\end{array}-20$ & 每8.2\% & 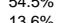 & $\begin{array}{l}63.6 \% \\
3.40 \%\end{array}$ & $\begin{array}{l}31.8 \% \\
6.8 \% 6\end{array}$ & $\begin{array}{l}50.5 \% \\
50 \%\end{array}$ & $\begin{array}{l}68.2 \% \\
31\end{array}$ & 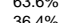 & & & & & & \\
\hline Total Don't Know (9) & $27.3 \%$ & $18.2 \%$ & $0.0 \%$ & $0.0 \%$ & $31.8 \%$ & $0.0 \%$ & $0.0 \%$ & $0.0 \%$ & $0.0 \%$ & $0.0 \%$ & & & & & & \\
\hline & & & & & & & & & & & & & & & & \\
\hline \% Scored "1" in & & $45.5 \%$ & $72.7 \%$ & $90.9 \%$ & $63.6 \%$ & $81.8 \%$ & $54.5 \%$ & & & & & & & & & \\
\hline$\%$ Sco & $0.0 \%$ & $0.0 \%$ & $0.0 \%$ & $16.7 \%$ & $33.3 \%$ & $33.3 \%$ & $16.7 \%$ & & & & & & & & & \\
\hline$\%$ Scored "1" in Bale & $0.0 \%$ & $40.0 \%$ & $40.0 \%$ & $80.0 \%$ & $60.0 \%$ & $60.0 \%$ & $0.0 \%$ & 100.0\% & $60.0 \%$ & 60 & & & & & & \\
\hline \% Scored "1" in All Tables & $18.2 \%$ & $31.8 \%$ & $45.5 \%$ & $68.2 \%$ & $54.5 \%$ & $63.6 \%$ & $31.8 \%$ & $95.5 \%$ & $68.2 \%$ & & & & & & & \\
\hline \% Scored "0" in L & & & & $\begin{array}{l}0.4 \\
9.1 \%\end{array}$ & & $\begin{array}{l}Q .6 \\
18.2 \%\end{array}$ & $\begin{array}{l}\text { Q. } \\
45.5 \%\end{array}$ & $\begin{array}{l}\text { Q.8\% } \\
0.0 \%-1\end{array}-10$ & $9.1 \%$ & $27.3 \%$ & & & & & & \\
\hline$\%$ Scored "0" of Right-Leaning Tables & & $100.0 \%$ & $100.0 \%$ & $83.3 \%$ & & $66.7 \%$ & & & & & & & & & & \\
\hline $\begin{array}{l}\text { \% Scored "0" in Balanced } \\
\% \text { Scored "0" in All Tables }\end{array}$ & $\begin{array}{l}100.0 \% \\
54.5 \%\end{array}$ & $\begin{array}{l}60.0 \% \\
50.0 \%\end{array}$ & $\begin{array}{l}60.0 \% \\
545 \%\end{array}$ & $20.0 \%$ & $40.0 \%$ & $40.0 \%$ & $100.0 \%$ & $0.0 \%$ & $40.0 \%$ & $40.0 \%$ & & & & & & \\
\hline 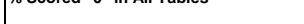 & & & & & & 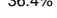 & & & & & & & & & & \\
\hline
\end{tabular}

As a reference, the ten questions that make up the Tax Distribution Table Scoring Index are repeated below.

1. Is a measure of income used other than cash income or Adjusted Gross Income (AGI)?

2. Is the unit of analysis families or households?

3. Is the percent change in after-tax income included in the analysis?

4. Is the percent of total tax change included in the analysis?

5. Are payroll taxes included in the analysis of taxes paid? 
6. Is the numbers of taxpayers residing within the income categories omitted?

7. Are ranges of income associated with each income category omitted?

8. Are ranges of tax liability associated with each income category omitted?

9. Are the current and proposed percent of total taxes paid for each income category omitted?

10. Are the current and proposed tax rates for each income category omitted?

\section{Observations and Patterns}

The most important observation is that the primary utility of the TDTSI is as an evaluation tool for policymakers and the public to apply to tax distribution tables to reveal the perspectives presented and balance any misleading or biased presentations of data. In day-to-day practice, policymakers and the public are not presented with a detailed text-based analysis of what is included or omitted in every distribution table. Further, as accurately depicted in a Washington Post article, "...in the tax debate, numbers can be easily manipulated to make a rhetorical point, so cutting through the maze of facts and statistics is difficult." ${ }^{46}$ What is needed is an evaluation tool that can provide the basic level of information necessary to effectively reveal and balance alternate perspectives presented in tax distribution tables, without requiring lengthy text-based descriptions. The TDTSI is such an evaluation tool.

The next observation is that conservative advocacy groups and think-tanks generally do not issue tax distribution tables. No verification could be found that conservative think-tanks released tax distribution tables into the public domain for any of the bills under analysis in this dissertation. Analyses were conducted on revenue and macroeconomic impacts, but not on tax distribution analysis per se. Though some tables might have been prepared for internal use, apparently none were released to the public. As stated in the research design, with respect to tax policy, conservatives tend to be more concerned with who pays for government (share of taxes paid) than they are with distributional issues in general. The very concept of a distribution table seems to imply to conservatives that it is the role of government to distribute income and wealth. Conservatives tend not to subscribe to this reasoning, as some liberals might.

Therefore, the conservative response to tax distribution tables has been to either criticize the tables released to the public on a variety of grounds or, as in the case with the OTA under President Bush, release distribution tables using different presentations of data in an attempt to counter the opposition. This is not to suggest that the TDTSI is only a tool for use against liberal tax analysis. As demonstrated in Chapter 6 and Chapter 7, the TDTSI is a tool of "good policy analysis." The TDTSI effectively identifies both liberal and conservative biases that are included (omitted) that affect the perspectives portrayed by tax distribution tables. Further, think-tanks such as the Heritage Foundation have the resources to create tax distribution tables and release them into the public domain. If conservative groups decide to publicly release tax distribution tables in the future, for example on tax reform issues, the TDTSI is available.

While all three scoring methods of the TDTSI provided similar results, the third method appears to be the most appropriate. The third method subtracts the number of left-leaning characteristics

${ }^{146}$ Glenn Kessler, “Tax Cut Debate’s Division Problem,” The Washington Post, May 17, 2001. 
from the number of right-leaning characteristics, and divides the result by the total number of questions in the coding scheme. For example:

$$
\text { Preference }_{\mathrm{LR}}=\left(\text { Preference }_{\mathrm{L}}-\text { Preference }_{\mathrm{R}}\right) / \text { Preference }_{\text {Total }}
$$

Structured in this manner, a score closer to 1 would be fully "liberal” and a score of "-1" fully "conservative."

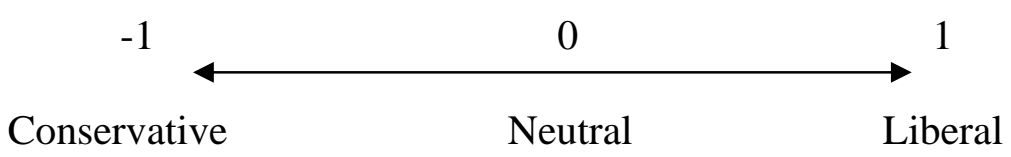

The benefit of using this third method is that zero becomes a middle point, suggesting that a table with a score of " 0 " is balancing political perspectives, or at least is not designed to bias toward a given tax policy position. Although the results of the research indicate that some tables that scored zero under this method still could be perceived as having a left- or right-leaning balance, the individual questions of the TDTSI effectively revealed which data were present and which data were missing so that end-users could still be informed as to the potential of misleading and biased presentations of data.

Also, though all of the questions in the TDTSI did not always accurately predict whether or not a table would in total portray liberal or conservative tax policy preferences (discussed below), the TDTSI always proved its worth as an evaluation tool for uncovering misleading or biased presentations of data which can affect perspectives. From just a good governance and good policy analysis standpoint, the TDTSI is a worthy tool in its own right.

From the standpoint of the organizations that issue tax distribution tables, it was interesting to see how the Joint Tax Committee's presentation of data first changed under Republican control and then second how the tables were eventually no longer made available to the public. With respect to the Office of Tax Analysis, the evidence suggests that that the party in power has some influence over what data is shown and not shown in a distribution table.

The results of the analysis suggest that advocacy groups such as Citizens for Tax Justice and Center on Budget and Policy Priorities conduct tax distribution analysis for the sole purpose of influencing the debate. Like a drunk who searches for his lost keys under the lamp because that's where the light is, distribution tables released by CTJ and CBPP are used more for illuminating their own policy perspectives than educating and informing the public. However, the role of issuing tax distribution tables has moved from these groups to the Tax Policy Center, a joint project between the Brookings Institution and the Urban Institute.

The Tax Policy Center has become the de facto non-government producer of tax distribution tables. As evidence by the tables presented in this chapter, TPC offers a variety of analyses and in a variety of presentations - some portraying liberal-leaning perspectives, some conservativeleaning perspectives, and some tables balanced between the two. The TDTSI is a useful tool for interpreting which perspectives are presenting in the numerous distribution tables TPC has made available to the public. 
With the increasing ease of placing data on the Internet and the cost of computing power declining, it is very likely that tax distribution tables will continue to be a prominent part of any future tax debate. The TDTSI will hopefully be a useful tool to ensure that end-users of tax distribution tables receive all of the necessary information required to arrive at a balanced perspective of a tax distribution analysis.

\section{Evaluation of the Individual Questions that Comprise the TDTSI}

Question \#1 - It is interesting to note that only the Treasury Department's Office of Tax Analysis (under the administration of President Clinton) and the Congressional Budget Office use an income measure that is left-leaning. This may be partly because of the imputations necessary to create an income measure such as Family Economic Income. Vast amounts of data and computing power are required to create such a measure. As a testament to the measure's liberalleaning perspective, as soon President Bush was in the White House, the use of FEI was abandoned at the Treasury Department. Only four tables (18\% of all tables; $36 \%$ of left-leaning tables) analyzed utilized a left-leaning income measure and all four tables were scored as leftleaning.

Question \#2 - If a unit of analysis other than tax returns is used, the result of such a broad-based measure will be less "units." Further, additions of income move families up the income ladder and give the perception that reductions in tax liabilities that would appear to benefit the middleclass under a tax return unit of analysis instead benefit higher income taxpayers. However, the use of families as the unit of analysis was not abandoned by the OTA once President Bush entered the White House. Whether this is an oversight of the administration, reluctance on behalf of the OTA staff or just an indifferent choice is unknown. This question did have an impact on whether or not a table ultimately presented left- or right-leaning policy perspectives, as no table identified as right-leaning used families as the unit of analysis. A family unit of analysis was included in seven tables (32\%); five of the tables scored as left-leaning (46\% of left-leaning tables) and two as balanced (40\% of balanced tables).

Question \#3 - If redistribution of income is a goal of liberal tax policy then an index question on whether or not after-tax income is included in a distribution table is necessary. Since, on a static basis, changes in income do not affect before-tax income, the primary way of measuring whether a tax change furthers redistributive goals is to focus on after-tax income. After-tax income has been identified as the preferred method of analysis by some scholars in the literature. This question in the TDTSI was a good indicator on whether or not a table ultimately presented leftor right-leaning policy perspectives, as no table scored right-leaning utilized this variable and eight tables scored as liberal-leaning did (73\%). Two tables scored as balanced presented this variable (40\%).

Questions \#4 - Focusing on the percent of total tax change has the effect of making distributionally neutral tax cuts appear regressive. This question in the TDTSI was rarely provided in tables that had an overall conservative-leaning score ( 1 table) and was a good indicator on whether or not a table ultimately presented left- or right-leaning policy perspectives. This variable was presented in 15 tables (68\%). This variable was included in ten tables scored as left-leaning (91\%) and four tables scored as balanced (80\%). 
Question \#5 - Including payroll taxes in the tax base has the effect of increasing the share of taxes paid by low-income groups, relative to federal income taxes alone, and increasing the share of income paid in taxes. Conservatives tend to argue that payroll taxes are delayed benefit; you get your money back when you retire. Hence, conservatives argue that payroll taxes should not be included in an analysis of individual income taxes. It was often difficult to determine if payroll taxes were included, as this item was not frequently disclosed one way or the other. It is interesting to note that the Bush OTA stop using payroll taxes in the calculation of tax burden, but still included payroll taxes paid by the employer to place their income measure on a pre-tax cash basis. This variable was as good indicator on whether or not a table ultimately presented left- or right-leaning policy perspectives. This variable was presented in 12 tables (55\%), and included in seven (64\%) of the left-leaning tables.

Question \#6 - Distribution tables that do not disclose the number of observations per group can be misleading by giving the impression that each grouping is made up of the same number of observations and possibly making any comparisons between the income groups misleading. However, many distribution tables failed to disclose the number of units in the stated income categories. In some tables, this was because quintiles were used - though the total number of units often was never disclosed. This variable was presented in 14 tables (64\%); nine out of eleven (82\%) of the left-leaning tables; two out of six of the right-leaning tables (33\%); and three of the five balanced tables (60\%).

Question \#7 - In order to effectively evaluate whether a current tax structure, or a change in taxation, is progressive or regressive, it is necessary to show income ranges. This question did prove to be a good indicator on whether or not a table ultimately presented right-leaning policy perspectives as five out of the six (83\%) of the tables scored as right-leaning omitted this information. However, this is contrary to what would be expected a prior. Conservatives should want to reveal income ranges so that proper income amounts can be applied to heuristic terms such as "middle-class." All of the tables scored as balanced omitted this information.

Question \#8 - A progressive tax system is one in which higher income taxpayers pay a higher percentage of their income in taxes. In order to effectively evaluate whether a current tax structure, or a change in taxation, is progressive or regressive, it is necessary to show income tax ranges. Only one table in the analysis showed this information (TPC Table $7-22$ ) and it failed to show negative tax amounts. This question did not prove to be a good indicator on whether or not a table ultimately presented left- or right-leaning policy perspectives. However, this information should be presented so that end-users have complete information.

Question \#9 - In order to evaluate whether or not a change to tax policy would result in a more or less progressive tax system, it is necessary to disclose the current and proposed levels of taxation. Groups wishing to hide the fact that a tax reduction that increases progressivity despite providing more nominal dollars in tax reduction to higher income groups would likely want to omit this important information. The tables that tended to portray conservative characteristics provided this information. This question did prove to be a good indicator on whether or not a table ultimately presented left- or right-leaning policy perspectives. 
Excluding the last two tables (Table 7-21 \& 7-22), which the TDTSI failed to accurately score the general policy perspectives, this variable was included in $100 \%$ of the tables scored as rightleaning by the TDTSI. Further, ten out of eleven (91\%) of the tables scored as liberal-leaning omitted this information.

Question \#10 - In order to evaluate whether or not a change to tax policy would result in a more or less progressive tax structure, it is necessary to disclose the current and proposed effective tax rates for each income group. Groups wishing to hide the fact that a tax reduction that increases progressivity despite providing more nominal dollars in tax reduction to higher income groups would likely want to omit this important information. This question was either a good predictor on whether or not a table ultimately presented left- or right-leaning policy perspectives or helped to balance the perspectives presented in the table, as eight out of eleven (73\%) of tables scored as left-leaning omitted this information.

\section{Additional Questions That Could Be Added to the TDTSI}

Lastly, there were some variables that were identified through the course of this analysis that might be useful to add to the TDTSI to make the index more thorough. Whether or not the addition of these questions would change the ability of the TDTSI to correctly identify the policy leanings portrayed in a distribution table is as of yet unknown. But, the following variables might wished to be studied further.

As the TDTSI original developed there were two questions that are not included now: Disclosure of statistical standards and inclusion of imputed data. However, these questions might made a good addition to an expanded TDTSI, if it is decided that the index should be expanded to include more than ten questions, or if some questions in the index should be replaced.

1) Are the accuracy and reliability of the estimates associated with the tax distribution tables and data omitted; are data limitations omitted?

This question primarily deals with transparency and whether or not that data presented in a distribution table is valid or reliable (Fichtner 2000). In tax distribution analysis, often no single data source exists that contains all of the information necessary to present population parameters. Rather, data derived from samples are used to make inferences about the population at large. In fact, numerous samples using different sample designs and targeting different sample segments are often combined with highly complex and subjective methodologies to create a single data source from which statistical inferences are made. Since tax distribution tables are based on complex statistical samples, the results are subject to many statistical problems including bias, errors in methodology, precision, accuracy, causality, and inference.

To properly use the estimates presented in any distribution table the magnitude of the potential sampling error must be known in order to make informed views relating to the significance of the estimates presented. All numbers based on sample data must be analyzed within the context of the sampling error. Unfortunately, such important information is usually missing from tax distribution tables. Further, without disclosing information such as confidence intervals, the statistical significance of the estimates can not be ascertained. The omission of these data, which 
would help determine the accuracy of the estimates, only hinders the policy debate and furthers the illusion of precision surrounding the estimates. If the public understood that the numbers often presented in tax distribution tables were subject to sampling error, the reliability of these data would then be subject to question. Not one distribution table was discovered that disclosed this information, which is why the question was dropped from the index.

2) Are any data or measures imputed?

Typically, imputed items are added to measures of income. However, tax data can also be imputed. With respect to income imputations, additions to income tend to push lower- and middle-income taxpayers up to a higher income level relative to an AGI measure. The inclusion of additional income items, including imputations relating to non-filer income, rental income from owner-occupied housing, inside buildup of life insurance, and unreported income, differs radically from the concept of AGI used by taxpayers on their tax returns. Moving taxpayers up the income ladder gives the perspective that reductions in tax liabilities that would actually be received by the middle income families are primarily benefiting the wealthy. Again, groups wishing to hide the fact that a tax reduction that increases progressivity despite providing more nominal dollars in tax reduction to higher income groups would likely want to omit this important information (Fichtner 2000).

This question was dropped from the index because it tended to double count against a table that had an income measure other than AGI or based on cash. By definition, if a broad-based income measure is used, it is more than likely that imputations were used to derive the measure.

3) Are nonfiling units included in the analysis?

Many of the distribution tables add people that do not pay taxes to the unit of analysis. This is a sort of imputation or creation of data and has the effect of adding more units of analysis to the lower income groups and artificially inflating the number of "taxpayers" who would not benefit from a tax cut.

4) Is the refundable portion of EITC or Child Tax Credit included in analysis?

Because the refundable portion of the EITC and CTC result in many lower-income taxpayers effectively paying no tax and some getting a net transfer from the government, the inclusion of this variable could be used to further conservative policy perspectives that upper-income groups bear a disproportionate share of the total tax burden and that you cannot give a tax cut to people who do not pay taxes. Liberals would want to omit this data.

5) Is the average tax cut a focus of the analysis?

A review of the distribution tables in this chapter show that many liberal-leaning tables present data on the average tax cut amount. In a progressive tax system, showing this information gives the appearance that lower-income groups receive a disproportionate share of the benefits. Conservatives tend to highlight share of taxes paid to counter the average tax cut measure. 
6) Is the average tax amount paid provided?

Opposite to average tax cut amount, the average amount of taxes paid (as a dollar figure) can also be used by conservatives to demonstrate that that upper-income groups bear a disproportionate share of the total tax burden and that you cannot give a tax cut to people who pay very little or no taxes. This variable was included in a distribution table released by the OTA under President Bush.

7) Are the numbers of taxpayers not paying taxes provided?

To address and counter the average tax cut amount, the numbers of taxpayers that either pay no tax or get a net transfer from the government can also be used by conservatives to demonstrate that that upper-income groups bear a disproportionate share of the total tax burden and that you cannot give a tax cut to people who pay very little or no taxes. This variable was included in a distribution table released by the JCT.

8) Are shares of total income (AGI) by income category provided?

Similar to showing data on percent of total taxes going to each income group, disclosing the share of income that each group receives would tend to further portray liberal-policy perspectives and fuel class warfare rhetoric since the upper income groups have a much larger share of total income. This variable was included in a TPC table.

Whether or not these variables should replace some of the current questions in the TDTSI, be ignored or included part of an expanded TDTSI is a question for further research. Also for further research, is whether a weighted index should be developed. Although a weighted scale could be devised, this author did not think it advisable to develop a weighted-index at this stage in the research. First, a non-weighted TDTSI needs to be evaluated first and the results evaluated by the research community. Second, the choice of which questions to weight and the weighting scheme itself would introduce some measure of bias that cannot be supported in the literature at this time. Hopefully, this dissertation research will provide the building blocks for the necessary support in the literature for future research on a weighted-TDTSI. 
Jason J. Fichtner

\section{CHAPTER 8 - CONCLUSIONS AND RECOMMENDATIONS}

\section{CONCLUSIONS}

The topic of tax distribution analysis and tax distribution tables specifically is an extremely important issue for public policy. The taxation of individual income is a vital component of tax policy. Legislators evaluating the fundamental components of tax legislation face decisions that often redistribute tax burdens, after-tax income, and wealth among different members of society and, on a larger scale, can affect the performance of the greater economy. Large amounts of data are available to policymakers to help them make informed decisions relating to the costs and benefits of proposed tax legislation as well as distributional income and wealth effects. However, the quantity and mixed quality of these data can lead to confusion about the effects of proposed tax legislation. This confusion is compounded when competing or contradictory information is presented.

Distribution tables have become ubiquitous to the tax policy debates surrounding major legislative initiatives to change tax law. The different economic assumptions and presentations of data used by the various groups that release distribution tables have the inherent consequence of providing the public with numerous tables showing different results that are then used as political ammunition to influence debate.

However, the literature has not kept pace with how distribution tables are used in the policy process and how the inclusion (omission) of different variables and methodologies applied to the analysis of those variables can influence the way key information is perceived, portrayed or defined in the public arena. Given the prominent role distribution tables have come to play in the tax policy process, it is appropriate to examine not only the use of distribution tables in the tax policy process but also what distribution tables show and do not show. It is important to illuminate how various groups construct their distributional analyses in order to present data in a manner that best supports certain policy perspectives.

Unfortunately, many tax distribution tables detailing the projected distribution of burdens associated with proposed tax legislation are presented in ways that can distort data or fail to disclose information regarding the limitations inherent in the data. Lacking such important information, informed debate over tax policy becomes difficult. Members of Congress, policymakers, students of tax analysis, the media and ordinary citizens seeking to understand the effects of proposed tax legislation are inundated with distribution tables that often obscure the issues and muddle the policy debate. A better and complete understanding of what distribution tables show, their limitations, and how different methodologies and definitions applied to key variables and the presentation of data within distribution tables can bias tax policy discussions is necessary. Further, a new policy tool is needed to evaluate the information presented (omitted) in tax distribution tables. This dissertation provides such a discussion and fills that need.

Doctoral dissertations, such as this dissertation, are now starting to emerge that identify the importance distributional analysis plays in the federal tax policy process. One such dissertation (Barry 2004) empirically demonstrates how conventional methodologies fail to accurately account for demographic characteristics and, therefore, provide a misleading picture of equity in 
the analysis of a proposed change to federal tax policy. The research presented in this dissertation fills the gap in the economics literature relating to tax distribution analysis and further bridges the literatures by triangulating on the economics, public finance and political science literatures.

This dissertation research contributes to the tax policy research literature by exploring the limitations and biases inherent in specific designs of tax distribution tables and with specific methodological approaches to tax distribution analysis. A systematic examination of how, in current practice, different designs and methodologies provide an incomplete picture of a proposed change to federal tax policy is presented in this dissertation. By comparing distribution tables as used by different groups to provide alternative perspectives of various tax proposals and how they can be perceived or portrayed in the public domain, the research shows that the use of tax distribution tables often provides misleading results about the distributional effects of proposed tax legislation.

This dissertation also contributes to the public finance literature by furthering the discussion on the importance of tax distribution tables to public policy (Hubbard 1993) and how tax distribution tables are used in the tax policy process. Also, this research contributes to the political science literature by furthering the discussion on issues such as conflict theory, (Stone 2002) which sets out to demonstrate that ideas are at the center of all political conflict and that policymaking can be seen as a constant struggle over the criteria for classification and the definition of ideas.

A method for evaluating tax distribution tables is provided and demonstrated in this dissertation research which highlights the deficiencies of design and methodology which characterize the present use of tax distribution tables. The method provided is an index of questions to serve as a new tool of policy analysis, an index I have created and termed the "Tax Distribution Table Scoring Index" (TDTSI). The TDTSI assists in balancing the different perspectives presented via tax distribution tables by identifying the biases and limitations associated with different methodologies and presentations of data. The results of the comparative research on the design and methodology of tax distribution tables, together with the demonstration of the TDTSI as an analytical tool, both contribute to the critical debates in the tax policy research literature as well as provide reform and add value to the practical use of tax distribution tables by policy makers and the public.

The primary utility of the TDTSI is as an evaluation tool for policymakers and the public to apply to tax distribution tables to reveal the perspectives presented and balance any misleading or biased presentations of data. In day-to-day practice, policymakers and the public are not presented with a detailed text-based analysis of what is included or omitted in every distribution table. What is needed is an evaluation tool that can provide the basic level of information necessary to effectively reveal and balance alternate perspectives presented in tax distribution tables, without requiring lengthy text-based descriptions. The TDTSI is such an evaluation tool.

This dissertation has demonstrated how tax distribution tables are often presented in manners that fail to provide balanced and accurate perspectives of tax policy. Unless there is greater public recognition of both the art and the science of distributional analysis, tax policy will be 
unduly influenced by misleading tax distribution tables. Although what is considered fair depends on philosophical and ethical judgments over which people can disagree, the presentation of tax data within distribution tables often hides or omits much of the important information that is required in order to effectively evaluate the distributional effects of any proposed tax legislation.

Scholars might argue that tax distribution tables cannot accurately summarize the complex and dynamic nature of income and wealth in the economy. Other scholars might argue that due to the current opaque nature of communicating even the simplest facts about tax policy to the American public, tax distribution tables should be abandoned as a basis for legislative decisionmaking.

Given that it is highly unlikely that the use of distribution tables will be abandoned, the best recommendation is that the public should demand full disclosure of any and all relevant data. Full disclosure includes, at the very least, a balanced presentation of the key data identified using the TDTSI. Additional disclosure should include using income measures that are understood by the public (like cash income or adjusted gross income), providing median values as well as averages, fully describing any imputations, conducting sensitivity analyses, disclosing measures of variance, and fully explaining the limitations of the data and subsequent distribution tables. By using the TDTSI, policymakers and the public can know what questions to ask and what data to demand.

\section{RECOMMENDATIONS FOR FOLLOW-ON RESEARCH}

First, the TDTSI is intended to be a growing policy analysis tool. The questions that are appropriate now and currently included in the TDTSI may not be appropriate in the future. Hence, whether or not the current ten variables should be replaced by some of the potential additional questions identified at the end of Chapter 7 or included as part of an expanded TDTSI should be pursued. Also for further research is whether a weighted index should be developed.

As a second avenue for further research, different methods of scoring using the TDTSI could be developed that would result in a more accurate representation of the policy perspectives portrayed by different tax distribution tables. Third, the TDTSI should be applied to further tax distribution tables to test the robustness of the index as a tool for policy evaluation. This dissertation research focused on a few key tax bills and on selective, though representative, tax distribution tables. Further, the TDTSI failed to accurately represent the policy perspectives of two distribution tables that showed selected information on the number of taxpayers not receiving a tax cut. Other tables where the TDTSI is ineffective should be researched and identified.

Also, the TDTSI could be applied to tax distribution tables that analyze the distribution of various tax reform proposals. How the TDTSI would evaluate a tax distribution table that analyzes a switch to a retail sales tax, value-added tax, or territorial tax system could be an interesting avenue for future research. 
Lastly, and most importantly, future research could appraise the ease of use of the TDTSI as a tool for policymakers and the public to evaluate tax distribution tables. The ultimate success of the TDTSI is if it has a positive impact on the practice of tax distribution analysis and the use of tax distribution tables in the policy process. 


\section{APPENDIX A - BIBLIOGRAPHY}

Auerbach, Alan J. "Public Finance and Tax Policy.” in Bradford, David F. (Ed.) Distributional Analysis of Tax Policy. Washington, DC: The AEI Press, 1995.

Barry, John. “Advances in Distributional Analysis.” A Dissertation Submitted to the Graduate Faculty of George Mason University, Economics. Fairfax, VA. 2004.

Barthold, Thomas A., James R. Nunns and Eric J. Toder. "A Comparison of Distribution Methodologies.” in Bradford, David F. (Ed.) Distributional Analysis of Tax Policy. Washington, DC: The AEI Press, 1995.

Barthold, Thomas A. “How Should We Measure Distribution?” National Tax Journal. Vol. 46, No. 3, September 1993.

. "Distributional Analysis at the Joint Committee on Taxation.” in Bradford, David F. (Ed.) Distributional Analysis of Tax Policy. Washington, DC: The AEI Press, 1995.

Bradford, David F. (Ed.) Blueprints for Basic Tax Reform. Arlington, VA: Tax Analysts, 1984. . Distributional Analysis of Tax Policy. Washington, DC: The AEI Press, 1995.

Bartlett, Bruce. Brief Analysis \#303: “Income Distribution.” National Center for Policy Analysis. Washington, DC. August 10, 1999.

Burman, Leonard. “Treasury’s New Distribution Presentation.” Tax Notes. March 26, 2001.

Burman, Leonard and David Gunter. “17 Percent of Families Have Stock Dividends.” Tax Notes. May 26, 2003.

Center on Budget and Policy Priorities. "Administration Continues to Rely on Misleading Use of ‘Averages’ to Describe Tax-Cut Benefits.” May 28, 2003.

. "Many Middle-Class Families Likely to Wind up as Net Losers From the 'Middle Class' Tax Cut Legislation.” September 28, 2004.

Citizens For Tax Justice. “House GOP Tax Plan: The Rich Get Richer.” CTJ News, released July 27, 1999.

. “CTJ Releases Distributional Analysis of GOP/Dems Marriage Penalty Bills.” CTJ News, released February 11, 2000.

. "House GOP Minimum Wage Plan Offers \$11 in Upper-Income Tax Brakes for Every \$1 in Wage Hikes for Low Earners.” March 7, 2000.

. "Bush Scales Back Tax Cut Plan to Trim Cost. New \$1.8 Trillion Plan Tilts Even More to Very Top.” Released May 11, 2000.

Cordes, Joseph J., Robert D. Ebel, and Jane G. Gravelle (Eds). The Encyclopedia of Taxation and Tax Policy. Washington, DC: The Urban Institute Press, 1999.

Council of Economic Advisors, Executive Office of the President of the United States, The Annual Report of the Council of Economic Advisors, together with the Economic Report of the President. Washington, DC: U.S. Government Printing Office, February 2003. 
Cronin, Julie-Anne. “U.S. Treasury Distributional Analysis Methodology.” U.S. Department of the Treasury. Office of Tax Analysis. OTA Paper 85. September 1999.

Cronin, Julie-Anne, and Janet Holtzblatt, Gillian Hunter, Janet McCubbin, James R. Nunns, and James Cilke, “Treasury’s New Panel Model for Tax Analysis," Prepared for the $96^{\text {th }}$ Annual Conference on Taxation, National Tax Association, Chicago, Il.. November 15, 2003.

Curl, Joseph. "Bush Celebrates Tax-Relief Extension.” The Washington Times. October 5, 2004.

Davis, Albert J. "Measuring the Distributional Effects of Tax Changes for the Congress." National Tax Journal, Vol. 46, No. 3, September 1991.

Feenberg, Daniel R. and James M. Poterba. "The Income and Tax Share of Very High-Income Households, 1960-1995.” American Economic Review, Vol. 90, No. 2, May 2000.

Fichtner, Jason J. “A Guide to Tax Policy Analysis: Problems with Distributional Tax Tables.” Joint Economic Committee. United States Congress. January 2000.

"A Guide to Tax Policy Analysis: The Central Tendency of Federal Income Tax Liabilities in Distributional Analysis.” Joint Economic Committee. United States Congress. May 2000.

. “The Misleading Effects of Averages in Tax Distribution Analysis.” Joint Economic Committee. September 2003.

. "A Comparison of Tax Distribution Tables: How Missing or Incomplete Information Distorts Perspectives.” Joint Economic Committee. December 2003.

. "A Comparison of Tax Distribution Tables: How Missing or Incomplete Information Distorts Perspectives.” A Report of the Heritage Center for Data Analysis. The Heritage Foundation. November 9, 2004. Available online at: http://www.heritage.org/Research/Taxes/cda04-13.cfm

. "Revenue Estimation: A Comparison of Tax Distribution Tables,” Tax Notes, Vol. 105, No. 13, December 20, 2004.

Frenze, Christopher. “Income Mobility and the U.S. Economy: Open Society or Caste System?” Joint Economic Committee. United States Congress. January 1992.

. “Income Mobility and Economic Opportunity." Joint Economic Committee. United States Congress. June 1992.

. “Treasury Department Estimates of Tax Changes: A Review and Analysis.” A Joint Economic Committee Brief. Washington, DC: Joint Economic Committee. United States Congress, July 1997.

. “Tax Reduction and the Economy.” Joint Economic Committee. United States Congress, July 1999.

Fullerton, Don and Diane Lim Rogers. Who Bears the Lifetime Tax Burden? Washington, DC: The Brookings Institution, 1993.

Fullerton, Don and Gilbert E. Metcalf (Eds.). The Distribution of Tax Burdens. Northampton, MA: Edward Elgar Publishing, Inc., 2003. 
Furchtgott-Roth, Diana. "Abuses of Income Distribution Tables in Tax Policy." Tax Notes. December 11, 1995.

Gale, William. “Distribution of Federal Taxes and Income, 1979-2000.” Tax Notes. September 29, 2003.

Gale, William and Peter Orszag. “The President's Tax Proposal: Second Thoughts.” Tax Notes. January 27, 2003.

. "Bush Administration Tax Policy: Distributional Effects.” Tax Notes. September 27, 2004.

. “Should the President’s Tax Cuts be Made Permanent?” Tax Notes. March 8, 2004.

Gale, William, Matthew Hall, and Peter Orszag. “Future Income Tax Cuts From the 2001 Tax Legislation.” Tax Notes. February 17, 2003.

Graetz, Michael J. “Distributional Tables, Tax Legislation, and the Illusion of Precision.” in Bradford, David F. (Ed.) Distributional Analysis of Tax Policy. Washington, DC: The AEI Press, 1995.

. “Paint-By-Numbers Tax Lawmaking.” Columbia Law Review, 95, 609, April 1995.

. “The Truth About Tax Reform.” University of Florida Law Review. Vol. 40, No. 4, Fall 1998.

Gravelle, Jane G. "Distributional Analysis, Tax Cuts by 'Stealth' and Taxation of Multinationals: Thoughts on Tax Issues in Memory of Albert J. Davis.” Proceedings Ninety-Sixth Annual Conference, National Tax Association. 2003.

_. "Distribution of the Tax Burden Across Individuals: An Overview." Congressional Research Service. United States Library of Congress. RL32693. December 13, 2004.

Gray, Jerry. "Congress and Taxes: The Reaction; Potshots From All Sides Offer Tax-Fight Preview.” The New York Times. June 10, 1997.

Haig, Robert Murray. “The Concept of Income - Economic and Legal Aspects.” in Haig, Robert Murray (Ed.) The Federal Income Tax. New York, NY: Columbia University Press, 1921.

Hardy, Cynthia, Bill Harley, and Nelson Phillips. “Discourse Analysis and Content Analysis?” Qualitative Methods. Vol. 2, No. 1, Spring 2004.

Hubbard, R. Glenn. “On the Use of 'Distribution Tables' in the Tax Policy Process.” National Tax Journal. Vol. 46, No. 4, December 1993.

. "Distributional Tables and Tax Policy.” in Bradford, David F. (Ed.) Distributional Analysis of Tax Policy. Washington, DC: The AEI Press, 1995.

Investment Company Institute and Securities Industry Association. Equity Ownership in America. Washington, DC: Fall 1999.

Johnston, David Cay. “Even for Wealthy, Tax Plan’s Benefits Could Vary Widely.” The New York Times. May 15, 2001. 
Kasten, Richard A. and Eric J. Toder. "Distributional Analysis at the Congressional Budget Office.” in Bradford, David F. (Ed.) Distributional Analysis of Tax Policy. Washington, DC: The AEI Press, 1995.

Kennedy, Peter. A Guide to Econometrics. Cambridge, MA: The MIT Press, 1992.

Kessler, Glenn. "Early Deductions: Despite What's Said About Tax Cuts, Here's What It Means.” The Washington Post. February 18, 2001.

—. “Treasury’s Tax Cut Data Can Cut 2 Ways.” The Washington Post. March 9, 2001.

—. “Tax Cut Debate’s Division Problem.” The Washington Post. May 17, 2001.

Kessler, Glenn and Eric Pianin. "White House Strikes Back on Tax Cuts.” The Washington Post. July 18, 2000.

Laver, Michael and John Garry. "Estimating Policy Positions from Political Texts.” American Journal of Political Science. Vol. 44, No. 3, July 2000.

Maier, Mark H. The Data Game - Controversies in Social Science Statistics. Armonk, New York: M.E. Sharpe, Inc, 1991.

Mastromarco, Dan R. “What’s So Fair About a Tax on Income?” Tax Notes. October 11, 1999.

Milbank, Dana and Chris Jenkins. "Bush Defends Tax Cut Proposal.” The Washington Post. January 10, 2003.

Mitchell, Dan. “Making a Bad Budget Even Worse.” Commentary. The Washington Times. June 2, 1993.

Montague, Bill. “Rich to Pick up the Tab.” The USA Today. August 4, 1993.

Murray, Shailah and David Rogers. "Democrats Attempt to Draw Rein As Republicans Study Wish List.” The Wall Street Journal. February 8, 2001.

Nelson, Susan C. "Family Economic Income and Other Income Concepts Used in Analyzing Tax Reform,” Compendium of Tax Research, 1986. Washington, DC: Office of Tax Analysis, Department of Treasury, 1987.

Nunns, James R. "Distributional Analysis at the Office of Tax Analysis.” in Bradford, David F. (Ed.) Distributional Analysis of Tax Policy. Washington, DC: The AEI Press, 1995.

O’Sullivan, Elizabethann, Gary R. Rassel, and Maureen Berner. Research Methods for Public Administrators (4 $\left.{ }^{\text {th }}\right)$. New York, NY: Addison Wesley Longman, Inc, 2003.

Pearlstein, Steven and Paul Blustein. “On the Class Warpath.” The Washington Post. February 7, 2001.

Penner, Rudolph G. “Searching for a Just Tax System,” Discussion Paper No. 13. UrbanBrookings Tax Policy Center. January 14, 2004.

Pianin, Eric. “Senate Votes ‘Marriage Penalty’ Relief.” The Washington Post. July 19, 2000.

Pianin, Eric. And Helen Dewar. "Senate GOP Tax Bill May Lead to Deal.” The Washington Post. July 28, 1999.

Poole, Keith T. and Howard Rosenthal. "Patterns of Congressional Voting,” American Journal of Political Science, Vol. 35, No. 1, February 1991. 
Simons, Henry C. Personal Income Taxation: The Definition of Income as a Problem of Fiscal Policy. Chicago, IL: The University of Chicago Press, 1938.

Schlesinger, Jacob M. and John D. McKinnon. "Bush Plan Gives Rich Biggest Cut in Dollars But Not in Percentage.” The Wall Street Journal. November 5, 2000.

Stamp, Josiah. Some Economic Factors in Modern Life. London: King and Son, 1929.

Stone, Deborah. Policy Paradox: The Art of Political Decision Making (Rev.). New York, NY: W.W. Norton \& Company, Inc., 2002

Sullivan, Martin. "Zen and the Art of Reading Distribution Tables.” Tax Notes. March 26, 2001.

_. "The Rise and Fall of Distribution Analysis.” Tax Notes. June 30, 2003.

Sweet, John K. “JGTRRA Relief Extended.” Tax Notes. November 8, 2004.

Tempalski, Jerry. "Revenue Effects of Major Tax Bills.” U.S. Department of the Treasury. Office of Tax Analysis. OTA Paper 81. Revised July 2003.

United States Congress, Joint Committee on Taxation. Methodology and Issues in Measuring Changes in the Distribution of Tax Burdens (JCS-7-93). June 14, 1993.

. Distributional Effects of the Conference Agreement for H.R. 1836, (JCX-52-01). May 26, 2001.

. Updated Distribution of Certain Federal Tax Liabilities by Income Class for Calendar Year 2001 (JCX-65-01). August 2, 2001.

United States Department of Commerce, Office of Federal Statistical Policy and Standards. "Statistical Policy Working Paper 5: Report on Exact and Statistical Matching Techniques.” Washington, DC: 1980.

United States Department of the Treasury, Office of Tax Analysis. "Major Provisions Passed by the House Ways and Means Committee." Released in a letter to Congressman Bill Archer, July 17, 2000.

. “Treasury Releases Distribution Table for the President's Tax Relief Plan.” Treasury Press Release PO-79, March 8, 2001.

United States General Accounting Office. Tax Expenditures: A Primer. (PAD 80-26), 1979.

- Content Analysis: A Methodology for Structuring and Analyzing Written Material. (Transfer Paper 10.1.3), March 1989.

. Using Statistical Sampling. (GAO/PEMD-10.1.6), May 1992.

. Quantitative Data Analysis: An Introduction. (GAO/PEMD-10.1.11), June 1992.

United States Internal Revenue Service. Publication 17. Your Federal Income Tax. Washington, DC.

. Statistics of Income Bulletin. Fall 1997. Washington, DC 1997.

. Statistics of Income Bulletin. Spring 1999. Washington, DC 1999.

. Statistics of Income Bulletin. Winter 1998-1999. Washington, DC 1999. 
. Statistics of Income Bulletin. Spring 2004. Washington, DC 2004.

. Statistics of Income Bulletin. Fall 2004. Washington, DC 2004.

United States Office of Management and Budget. Executive Office of the President. Circular NO. A-130. Washington, DC 1996.

VandeHei, Jim. "Bush Enacts Fourth Tax Cut; Law Will Benefit Married Couples, Parents and Businesses.” The Washington Post. October 4, 2004.

Weisman, Jonathan. “New Tax Plan May Bring Shift in Burden.” The Washington Post. December 16, 2002.

. “Liberal Group Decries Corporate Tax Slide.” The Washington Post. September 23, 2004.

Weiss, Carol H. “Congressional Committees as Users of Analysis” Journal of Policy Analysis and Management. Vol. 8, No. 3, 1989.

Wilkie, Patrick J. “A Critical Analysis of Tax Distribution Studies Conducted by the Congressional Budget Office.” Tax Foundation Background Paper \#2. Washington, DC: The Tax Foundation, November 18, 1992.

Wolf, Richard. “Parties Class on Who’ll Pay Budget Bill Tab.” The USA Today. June 24, 1993. 


\section{APPENDIX B - SELECTED RESOURCES FOR FUTURE READING}

Note: The following resources do not necessarily deal with tax distribution analysis or tax policy. Rather. The following resources are provided as additional sources for those interested in reading more about strategic management and how the use of data can be designed to portray policy perspectives and agendas.

Allison, Graham and Philip Zelikow. Essence of Decision: Explaining the Cuban Missile Crisis $\left(2^{\text {nd }}\right)$. New York, NY: Addison-Wesley Educational Publishers, 1999.

American Institute of Certified Public Accountants and Martin A. Sullivan. Changing America's Tax System. New York, NY: John Wiley \& Sons, Inc., 1996.

Ansolabehere, James M. Snyder, JR, and Charles Stewart, III. "Candidate Positioning in the U.S. House of Elections,” American Journal of Political Science, Vol. 45, No. 1, January 2001.

Baumgartner, Frank R. and Bryan D. Jones. Agendas and Instability in American Politics. Chicago, IL: University of Chicago Press, 1993.

—. "Attention, Boundary Effects, and Large-Scale Policy Change in Air Transportation Policy.” in Rochefort and Cobb. The Politics of Problem Definition: Shaping the Policy Agenda. Lawrence, Kansas: University of Kansas Press, 1994.

Best, Joel. Damned Lies and Statistics. Berkeley, CA: University of California Press, 2001.

Browning, Edgar K. “Tax Incidence Analysis for Policy Makers.” in Bradford, David F. (Ed.) Distributional Analysis of Tax Policy. Washington, DC: The AEI Press, 1995.

“The Case Against Income Redistribution.” Public Finance Review, Vol. 30, No. 6, November 2002.

Chilton, Paul and Christina Schaffner (Eds). Politics as Text and Talk. Philadelphia, PA: John Benjamins Publishing Company, 2002.

Cilke, James, and Julie-Anne M. Cronin, Janet McCubbin, James R. Nunns, and Paul Smith. "Distributional Analysis: A Longer Term Perspective." National Tax Association Proceedings of the Ninety-Third Annual Conference. 2000.

Combs, James E. and Dan Nimmo. The New Propaganda: The Dictatorship of Palaver in Contemporary Politics. White Plains, NY: Longman Publishing Group, 1993.

—. The Comedy of Democracy. Westport, CT: Praeger Publishers, 1996.

Cyert, Richard M. and James G. March. A Behavioral Theory of the Firm $\left(2^{\text {nd }}\right)$. Malden, MA: Blackwell Publishers, 196, 1992.

Dye, Thomas. Understanding Public Policy $\left(2^{\text {nd }}\right) .1992$.

Fan, David P. “Computer Content Analysis of Press Coverage and Prediction.” Social Science Computer Review. Vol. 15, No. 4, Winter 1997.

Gabel, Matthew J. and John D. Huber. "Putting Parties in Their Places: Inferring Party LeftRight Ideological Positions from Party Manifestos Data.” American Journal of Political Science. Vol. 44, No. 1. January 2000. 
Gillespie, Judith A. and Dina A. Zinnes (Eds). Missing Elements in Political Inquiry: Logic and Levels of Analysis. Beverly Hills, CA: Sage Publications, 1982.

Groseclose, Tim, Steven D. Levitt, and James M. Snyder, Jr. "Comparing Interest Group Scores Across Time and Chambers: Adjusted ADA Scores for the U.S. Congress," The American Political Science Review, Vol. 93, No. 1, March 1999.

Heckman, James J. and James M. Snyder Jr. "Linear Probability Models of the Demand for Attributes with an Empirical Application to Estimating the Preferences of Legislators," The RAND Journal of Economics, Vol. 28, No. 0, Special Issue in Honor of Richard E. Quandt, 1997

Helberg, Clay. "Pitfalls of Data Analysis (or How to Avoid Lies and Damned Lies).” SPSS, Inc. Available online at: http://www.execpc.com/ helberg/pitfalls/

Hinch, Melvin J. and Michael C. Munger. Analytical Politics. New York, NY: Cambridge University Press, 1997.

Jenkins, Richard W. "How Much Is Too Much? Media Attention and Popular Support for an Insurgent Party.” Political Communication. Vol. 16, 1999.

Kaid, Lynda Lee, John C. Tedesco and Lori Melton McKinnon. "Presidential Ads as Nightly News: A Content Analysis of 1988 and 1992 Televised Adwatches.” Journal of Broadcasting \& Electronic Media. Vol. 40, Summer 1996.

Kanter, Arnold. Defensive Politics: A Budgetary Perspective. Chicago, IL: The University of Chicago Press, 1975, 1979.

Kingdon, John W. Agenda, Alternatives, and Public Policy. 1984.

Krehbiel, Keith. “Spatial Models of Legislative Choice,” Legislative Studies Quarterly, Vol. 13, No. 3, August 1988.

Krippendorff, Klaus. Content Analysis: An Introduction to Its Methodology. Beverly Hills, CA: Sage Publications, 1980.

Lesser, Judith T. and William D. Kalsbeek. Nonsampling Error in Surveys. New York, NY: John Wiley \& Sons, Inc., 1992.

Levit, Steven D. "How Do Senators Vote? Disentangling the Role of Voter Preferences, Party Affiliation, and Senator Ideology,” The American Economic Review, Vol. 86, No. 3, June 1996.

Lillard, Lee, James P. Smith, and Finis Welch. "What Do We Really Know about Wages? The Importance of Nonreporting and Census Imputation.” The Journal of Political Economy. Vol. 94, No. 3. June 1986.

Little, Roderick J.A., and Donald B. Rubin. Statistical Analysis with Missing Data. New York, NY: John Wiley \& Sons, Inc., 1987.

Lowi, Theodore J. “American Business, Public Policy Case Studies and Political Theory.” World Politics. July 1964.

“Decision Making vs. Policy Making: Toward an Antidote For Technocracy.” Public Administration Review. May/June 1970. 
March, James G. and Johan P. Olsen. Rediscovering Institutions: The Organizational Basis of Politics. New York, NY: The Free Press, 1989.

Mastromarco, Dan R. “What’s So Fair About a Tax on Income?” Tax Notes. October 11, 1999.

McKelvey, Richard D., and Peter C. Ordeshook. "Information, Electoral Equilibria, and the Democratic Ideal,” The Journal of Politics, Vol. 48, No. 4, November 1986.

McManus, Susan A. “"Bricks and Mortar” Politics: How Infrastructure Decisions Defeat Incumbents.” Public Budgeting \& Finance, Spring 2004.

Merrill III, Samuel and Bernard Grofman. A Unified Theory of Voting. Cambridge, UK: Cambridge University Press, 1999.

Mintzberg, Henry. The Rise and Fall of Strategic Planning. New York, NY: The Free Press, 1994.

Mucciaroni, Gary. "Problem Definition and Special Interest Politics in Tax Policy and Agriculture. in Rochefort and Cobb. The Politics of Problem Definition: Shaping the Policy Agenda. Lawrence, Kansas: University of Kansas Press, 1994.

Nelkin, Dorothy. “The Political Impact of Technical Expertise.” Social Studies of Science. 1975.

Neuendorf, Kimberly A. The Content Analysis Guidebook. Thousand Oaks, CA: Sage Publications, Inc., 2002.

Nimmo, Dan D. Popular Images of Politics: A Taxonomy. Englewood Cliffs, NJ: Prentice-Hall, 1974.

North, Robert C., Ole R. Holsti, M. George Zaninovich and Dina A. Zinnes. Content Analysis: A Handbook with Applications for the Study of International Crisis. Northwestern University Press, 1963.

Owen, Diana, Richard Davis and Vincent James Strickler. "Congress and the Internet." The Harvard International Journal of Press/Politics. Vol. 4, No. 2, Spring 1999.

Pechman, Joseph A. Federal Tax Policy (5 ${ }^{\text {th }}$ Edition). Washington, DC: The Brookings Institution, 1987.

Pfeffer, Jeffrey. Power In Organizations. Marshfield, MA: Pittman Publishing, 1981.

Poole, Keith T. “NOMINATE: A Short Intellectual History,” Available online at:

http://voteview.com/

Poole, Keith T., and R. Steven Daniels. "Ideology, Party, and Voting in the U.S. Congress, 1959-1980,” The American Political Science Review, Vol. 79, No. 2, June 1985.

Poole, Keith T., Thomas Romer, and Howard Rosenthal. “The Revealed Preferences of Political Action Committees,” The American Economic Review, Vol. 77, No. 2, May 1987.

Poole, Keith T. and Howard Rosenthal. “The Polarization of American Politics,” The Journal of Politics, Vol. 46, No. 4, November 1984.

. “A Spatial Model for Legislative Roll Call Analysis,” American Journal of Political Science, Vol. 29, No. 2, May 1985. 
"Analysis of Congressional Coalition Patterns: A Unidimensional Spatial Model," Legislative Studies Quarterly, Vol. 12, No. 1, February 1987.

Poole, Keith T, Howard Rosenthal and Kenneth Koford. "On Dimensionalizing Roll Call Votes in the U.S. Congress,” The American Political Science Review, Vol. 85, No. 3, September 1991.

Portz, John. "Plant Closings, Community Definitions, and the Local Response. in Rochefort and Cobb. The Politics of Problem Definition: Shaping the Policy Agenda. Lawrence, Kansas: University of Kansas Press, 1994.

Rao, J.N.K. “On Variance Estimation with Imputed Survey Data.” Journal of American Statistical Association. Vol. 91, No. 434. June 1996.

Riker, William H. "Implications from the Disequilibrium of Majority Rule for the Study of Institutions,” The American Political Science Review, Vol. 74, No. 2, June 1980.

Rochefort, David A. and Roger W. Cobb. "Problem Definition, Agenda Access, and Policy Choice.” Policy Studies Journal. Vol. 21. No. 1. Spring 1993.

Roberts, R. and LER Dean. “An Inquiry into Lowi’s Policy Typology: The Conservation Coalition and the 1985 and 1990 Farm Bills.” Environment and Planning C: Government and Policy, Vol. 12. 1994.

Rochefort, David A. and Roger W. Cobb (Eds.). The Politics of Problem Definition: Shaping the Policy Agenda. Lawrence, Kansas: The Kansas University Press, 1994.

Roemer, John E. Political Competition: Theory and Applications. Cambridge, MA: Harvard University Press, 2001.

Rubin, Donald B. Multiple Imputation For Nonresponse Surveys. New York, NY: John Wiley \& Sons, Inc., 1987.

Sabatier, Paul A. and Hank C. Jenkins-Smith (1999). "The Advocacy Coalition Framework: An Assessment,” in Sabatier, Paul A. (Ed.), Theories of the Policy Process. (1999).

Schattschneider, E.E. The Semi-Sovereign People: A Realist's View of Democracy in America. New York, NY: Holt, Rinehart, and Winston, 1960.

Schuyler, Michael and Stephen J. Entin. “The Gore Tax Plan: Redistribution, Not Reform.” Institute for Research on the Economics of Taxation, Policy Bulletin No. 82. Washington, DC: September 20, 2000.

Selznick, Philip. Leadership in Administration: A Sociological Interpretation. Berkeley, CA: University of California Press, 1957, 1984.

Shepsle, Kenneth A. Analyzing Politics: Rationality, Behavior, and Institutions. New York, NY: W.W. Norton \& Company, Inc., 1997.

Sims, Christopher, A. “Comments on Kadane’s Work on Matching to Create Synthetic Data.” In 1978 Compendium of Tax Research sponsored by the Office of Tax Analysis, U.S. Department of Treasury.

Steinbruner, John D. cybernetic Theory of Decision: New Dimensions of Political Analysis. Princeton, NJ: Princeton University Press, 1974. 
Stewart III, Charles. Analyzing Congress. New York, NY: W.W. Norton \& Company, Inc., 2001.

Ture, Norman B. and B. Kenneth Sanden. The Effects of Tax Policy on Capital Formation. New York, NY: Financial Executives Research Foundation, 1977.

Zinnes, Dina A. "Review of "Content Analysis: A Technique for Systematic Inference from Communications.” The American Political Science Review. Vol. 68, No. 2, June 1974. 